Routledge Explorations in Development Studies

\title{
PRACTICES OF CITIZENSHIP IN EAST AFRICA
}

PERSPECTIVES FROM PHILOSOPHICAL PRAGMATISM

Edited by

Katariina Holma and Tiina Kontinen

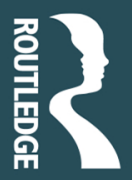


"This vital collection offers fresh insight into the nature of citizen engagement. Challenging liberal and universalist framings of democratic participation, the authors focus on people's everyday habits, practices and experiences of cooperation for livelihoods and survival. Citizenship is repositioned as a gradual, learned and contextual process that spans public and private life. This highly empirical and theoretically innovative work by African and European scholars is essential reading."

— Jethro Pettit, Emeritus Fellow, Institute of Development Studies, University of Sussex, UK 
$\Longrightarrow$ Taylor \& Francis

Taylor \& Francis Group

http://taylorandfrancis.com 


\section{Practices of Citizenship in East Africa}

Practices of Citizenship in East Africa uses insights from philosophical pragmatism to explore how to strengthen citizenship within developing countries. Using a bottom-up approach, the book investigates the various everyday practices in which citizenship habits are formed and reformulated. In particular, the book reflects on the challenges of implementing the ideals of transformative and critical learning in the attempts to promote active citizenship.

Drawing on extensive empirical research from rural Uganda and Tanzania and bringing forward the voices of African researchers and academics, the book highlights the importance of context in defining how habits and practices of citizenship are constructed and understood within communities. The book demonstrates how conceptualizations derived from philosophical pragmatism facilitate identification of the dynamics of incremental change in citizenship. It also provides a definition of learning as reformulation of habits, which helps to understand the difficulties in promoting change.

This book will be of interest to scholars within the fields of development, governance, and educational philosophy. Practitioners and policy-makers working on inclusive citizenship and interventions to strengthen civil society will also find the concepts explored in this book useful to their work.

Katariina Holma is Professor of Education at the University of Oulu, Finland.

Tiina Kontinen is an Academy of Finland Research Fellow at the Department of Social Sciences and Philosophy, University of Jyväskylä, Finland. 


\section{Routledge Explorations in Development Studies}

This Development Studies series features innovative and original research at the regional and global scale. It promotes interdisciplinary scholarly works drawing on a wide spectrum of subject areas, in particular politics, health, economics, rural and urban studies, sociology, environment, anthropology, and conflict studies.

Topics of particular interest are globalization; emerging powers; children and youth; cities; education; media and communication; technology development; and climate change.

In terms of theory and method, rather than basing itself on any orthodoxy, the series draws broadly on the tool kit of the social sciences in general, emphasizing comparison, the analysis of the structure and processes, and the application of qualitative and quantitative methods.

\section{Valuing Development, Environment and Conservation}

Creating Values that Matter

Edited by Sarah Bracking, Aurora Fredriksen, Sian Sullivan and Philip

Woodhouse

Engendering Transformative Thinking and Practice in International

Development

Gillian Fletcher

New Donors on the Postcolonial Crossroads

Eastern Europe and Western Aid

Tomáš Profant

The Power of Civil Society in the Middle East and North Africa

Peace-building, Change, and Development

Edited by Ibrahim Natil, Chiara Pierobon, and Lilian Tauber

Global Business Cycles and Developing Countries

Eri Ikeda

Practices of Citizenship in East Africa

Perspectives from Philosophical Pragmatism

Edited by Katariina Holma and Tiina Kontinen

Political Financing in Developing Countries

A Case from Ghana

Joseph Luna 


\title{
Practices of Citizenship in East Africa
}

Perspectives from Philosophical

Pragmatism

\author{
Edited by \\ Katariina Holma and Tiina Kontinen
}

Routledge

LONDON AND NEW YORK 
First published 2020

by Routledge

2 Park Square, Milton Park, Abingdon, Oxon OX14 4RN

and by Routledge

52 Vanderbilt Avenue, New York, NY 10017

Routledge is an imprint of the Taylor \& Francis Group, an informa business

(C) 2020 selection and editorial matter, Katariina Holma and Tiina Kontinen; individual chapters, the contributors

The right of Katariina Holma and Tiina Kontinen to be identified as the authors of the editorial material, and of the authors for their individual chapters, has been asserted in accordance with sections 77 and 78 of the Copyright, Designs and Patents Act 1988.

All rights reserved. No part of this book may be reprinted or reproduced or utilised in any form or by any electronic, mechanical, or other means, now known or hereafter invented, including photocopying and recording, or in any information storage or retrieval system, without permission in writing from the publishers.

Trademark notice: Product or corporate names may be trademarks or registered trademarks, and are used only for identification and explanation without intent to infringe.

British Library Cataloguing-in-Publication Data

A catalogue record for this book is available from the British Library

Library of Congress Cataloging-in-Publication Data

Names: Holma, Katariina, editor, author. | Kontinen, Tiina, editor, author.

Title: Practices of citizenship in East Africa : perspectives from

philosophical pragmatism / edited by Katariina Holma and Tiina Kontinen.

Identifiers: LCCN 2019031767 (print) | LCCN 2019031768 (ebook) | ISBN

9780367232962 (hardback) | ISBN 9780429279171 (ebook)

Subjects: LCSH: Citizenship--Tanzania. | Citizenship--Uganda. |

Democracy--Tanzania. | Democracy--Uganda.

Classification: LCC JQ3519.A2 P73 2020 (print) | LCC JQ3519.A2 (ebook) |

DDC 323.609678--dc23

LC record available at https://lccn.loc.gov/2019031767

LC ebook record available at https://lecn.loc.gov/2019031768

ISBN: 978-0-367-23296-2 (hbk)

ISBN: 978-0-429-27917-1 (ebk)

Typeset in Times New Roman

by Taylor \& Francis Books 


\section{Contents}

List of illustrations $\quad$ ix

Acknowledgements $\mathrm{x}$

List of contributors $\quad \mathrm{xi}$

1 Introduction 1

TIINA KONTINEN AND KATARIINA HOLMA

\section{PART I}

Concepts anchored in philosophical pragmatism 13

2 Practices and habits of citizenship and learning 15 KATARIINA HOLMA AND TIINA KONTINEN

3 Pragmatism, social inquiry and the method of democracy 29 HENRIK RYDENFELT

4 John Dewey's notion of social intelligence 44 VELI-MIKKO KAUPPI, KATARIINA HOLMA AND TIINA KONTINEN

\section{PART II}

Localized practices and habits of citizenship 55

5 Contextualizing citizenship in Uganda 57 HENNI ALAVA, TWINE H. BANANUKA, KAREMBE F. AHIMBISIBWE AND TIINA KONTINEN

6 Contextualizing citizenship in Tanzania 73 AJALI M. NGUYAHAMBI, HAJI H. CHANG'A, BENTA N. MATUNGA, REHEMA G. KILONZO AND TIINA KONTINEN 


\section{viii Contents}

7 The everyday and spectacle of subdued citizenship in northern Uganda HENNI ALAVA

8 Gendered citizenship in rural Uganda: localized, exclusive and active

ALICE N. NDIDDE, KAREMBE F. AHIMBISIBWE AND TIINA KONTINEN

9 "A good believer is a good citizen": connecting Islamic morals with civic virtues in rural Tanzania

AJALI M. NGUYAHAMBI AND TIINA KONTINEN

10 Habits of contributing citizenship: self-help groups in rural Tanzania

REHEMA G. KILONZO, BENTA N. MATUNGA, HAJI H. CHANG'A AND TIINA KONTINEN

\section{PART III}

\section{Transformative ideals and incremental change}

11 Participatory methodology in exploring citizenship: a critical learning process

KAREMBE F. AHIMBISIBWE, ALICE N. NDIDDE AND TIINA KONTINEN

12 Learning in a Ugandan gender advocacy NGO: organizational growth and institutional wrestling TIINA KONTINEN AND ALICE N. NDIDDE

13 The crafting of "critical education": experiences of a Ugandan NGO

TWINE H. BANANUKA AND VAUGHN M. JOHN

14 Social accountability monitoring as an approach to promoting active citizenship in Tanzania

AJALI M. NGUYAHAMBI AND HAJI H. CHANG'A

15 Conclusions

TIINA KONTINEN AND KATARIINA HOLMA 


\section{Illustrations}

\section{Figures}

11.1 A Venn diagram drawn using distance to show groups of non/ importance in Namunyuka Village, Kiboga District.

11.2 A Venn diagram drawn using size (and distance) to show groups of non/importance in Kajjere Village, Kiboga District.

11.3 A Venn diagram of a female teacher and councillor in Kiboga District. She encircles everything with her teaching profession, arguing that her job at a local primary school was the main reason for her involvement in all the other activities and groups.

11.4 A Venn diagram of a male participant emphasizing the significance of religion. He drew a bigger Venn for his local church, Bubago Church of Uganda. "It's because of God that am still alive and talking to you now", he said.

11.5 A participant guiding the researcher in drawing her Venn diagram in Kiboga district. She argued that she could not write on the ground as if she was a child.

\section{Table}

1.1 The empirical research material collected in the GROW research project.

\section{Boxes}

5.1 Facts about Uganda

6.1 Facts about Tanzania 


\section{Acknowledgements}

We would like to acknowledge the funding received from the Development Research Programme of the Academy of Finland for the project Growth into Citizenship in Civil Society Encounters (GROW) for 2015-2019 (decision numbers 285812 and 285815), without which this collaborative endeavour would not have been possible. We thank Kone Foundation, Finland, for some financial resources. Moreover, we are grateful for the Department of Development Studies at the University of Dodoma and the Department of Adult and Community Education at Makerere University, which contributed significant amount of their staff-time and other resources for the successful accomplishment of the project. The biggest thanks go to the NGOs, the village leaders and inhabitants of rural areas in Tanzania and Uganda for allocating their time and providing numerous opportunities for learning for our research team. Finally, we thank our research assistant Henna-Mari Koskela for her excellent work in the technical finalizing of the manuscript. 


\section{Contributors}

Karembe Fabian Ahimbisibwe is a Lecturer and a Head of Department in the Department of Adult and Community Education in the School of Distance and Lifelong Learning at Makerere University, Uganda. He is also a $\mathrm{PhD}$ candidate at the University of Jyväskylä, Finland.

Henni Alava, $\mathrm{PhD}$, is a postdoctoral researcher in the Department of Social Sciences and Philosophy at the University of Jyväskylä, Finland.

Twine Hannington Bananuka, $\mathrm{PhD}$, is a Lecturer in the Department of Adult and Community Education in the School of Distance and Lifelong Learning at Makerere University, Uganda, and a postdoctoral researcher in the Theory and Practice of Learning into Citizenship - project (CSLEARN).

Haji Hashimu Chang'a is an Assistant Lecturer and the Head of Department in the Department of Political Science and Public Administration at the University of Dodoma, Tanzania.

Katariina Holma, $\mathrm{PhD}$, is a Professor of Education at the University of Oulu, Finland. She is the principal investigator of the consortium Growth into Citizenship in Civil Society Encounters (GROW).

Vaughn Mitchell John, PhD, is a Professor of Adult Education in the School of Education at the University of Kwazulu-Natal, South Africa.

Veli-Mikko Kauppi is a $\mathrm{PhD}$ candidate at the Faculty of Education, University of Oulu, Finland.

Rehema Godfrey Kilonzo, $\mathrm{PhD}$, is a Senior Lecturer in the Department of Development Studies and a Dean of the School of Social Sciences at the University of Dodoma, Tanzania, and the local coordinator of the Growth into Citizenship in Civil Society Encounters - project (GROW).

Tiina Kontinen, $\mathrm{PhD}$, is an Academy of Finland Research Fellow at the University of Jyväskylä and a co-principal investigator of the Growth into Citizenship in Civil Society Encounters - project (GROW). 


\section{xii List of contributors}

Benta Nyamanyi Matunga, $\mathrm{PhD}$, is a Lecturer in the Department of Development Studies at the University of Dodoma, Tanzania, and a postdoctoral researcher in the Theory and Practice of Learning into Citizenship - project (CS-LEARN).

Alice Nankya Ndidde is a Lecturer in the Department of Adult and Community Education in the School of Distance and Lifelong Learning at Makerere University, Uganda, and the local coordinator of the Growth into Civil Society Encounters - project (GROW).

Ajali Mustafa Nguyahambi, $\mathrm{PhD}$, is a postdoctoral researcher in the Department of Social Sciences and Philosophy at the University of Jyväskylä, Finland, and a Lecturer in the Department of Political Science and Public Administration at the University of Dodoma, Tanzania.

Henrik Rydenfelt, $\mathrm{PhD}$, is a postdoctoral researcher at the Faculty of Education at the University of Oulu, Finland. 


\title{
1 Introduction
}

\author{
Tiina Kontinen and Katariina Holma
}

In this book, we offer a number of illustrations of what citizenship means and how it is practiced in selected locations in Tanzania and Uganda. Moreover, we discuss the potential contribution of philosophical pragmatism when it comes to conceptualizing citizenship in general, and in everyday practices in these East African contexts in particular. Therefore, we hope, on the one hand, that the phrase "philosophical pragmatism" in the book title will not scare off those interested in practices in these particular contexts, and on the other, that those having a more conceptual interest will be inspired to reflect further on the implications of these particular contexts for theorizing about citizenship. In other words, we would like to invite any reader interested in citizenship, from everyday practice to philosophical conceptualization to join us for a dialogue.

Three ongoing debates have motivated us to engage in a dialogue between development research and pragmatist philosophy. First, we respond to the eagerness of development research to contribute to "intentional development" (Cowen \& Shenton 1996) and, therefore, to use theories and concepts in a normative way: to describe what should be the end state of "development" and accordingly, to prescribe needed interventions in order to reach the desired situation. While, as researchers, we cannot, and should not, escape our normative ideas of what the good life is, our analytical endeavour nevertheless seeks a relatively non-normative starting point with a focus on analyzing the present situation. Second, we seek to adhere to the methodological principle of philosophical pragmatism according to which concepts and theories should be informed by human practices and developed through joint inquiry. In accordance with this view, our aim is to investigate selected philosophical concepts through inquiry into practices in African locations, which are often marginalized from philosophical theorization. Third, we were motivated by the recent debates in development studies concerning the importance of civil society and citizen engagement in societal change and, consequently, chose the notion of citizenship, extensively discussed in both development research and philosophy, as the locus of our inquiry. 


\section{Kontinen and Holma}

These three motivations, discussed in detail below, set the academic framework for the book, which is not clearly situated in any particular discipline. It represents a genuine attempt to make sense of everyday citizenship by drawing on contributions from a variety of disciplines. It presents selected findings from a four-year research project, "Growth into citizenship in civil society encounters" (2015-2019), and is thus an important milestone in a collaborative research journey that has combined expertise in educational philosophy, philosophical pragmatism, adult education, sociology, political science and development studies from four universities: the University of Dodoma, Tanzania; Makerere University, Uganda; and the Universities of Jyväskylä and Oulu, Finland.

\section{Development research: The practical relevance of theory}

Development research has continually argued for knowledge production that is relevant and useful for development policy and practice, and, most importantly, for those whose lives "development" is supposed to improve. In relation to defining relevance, development theories hold different normative or ideological underpinnings in regard to the nature and desired direction of social change (Thomas 2000, 42), and how to address this change by means of intentional development interventions. For instance, the tensions between incremental and transformative societal change in regard to the role of civil society in development are constantly debated (Mitlin et al. 2007), the former being inspired by de Tocquevillean tradition of civil society seen as primarily a sphere of associations and citizens' organizing, the latter stemming from a Gramscian view understanding civil society as potential space for counterhegemonic collective action (Howell \& Pearce 2002; Kontinen \& Melber 2015). The proponents of transformative change argue that incremental improvements will not bring about changes at the systemic level and, thus, cannot address the prevalent inequalities resulting in situations such as a lack of social justice or marginalization (Hickey \& Mohan 2004).

Moreover, development scholars and anthropologists often hold different views on the role of research, on whether its goal should be to conduct "analysis" or facilitate the "design" of interventions. Development research typically seeks knowledge that could contribute to change and transformation, while anthropology stresses the importance of more descriptive analysis (Crewe \& Axelby 2013; Green 2012) and "knowing how the world is before trying to change it" (Olivier de Sardan 2005). Moreover, there are arguments from various normative bases about needed changes in development studies itself. The recent debates on transformations (Alff \& Hornidge 2019), decolonialization (Schöneberg 2019) and engaged excellence (Oswald et al. 2019) effectively capture reflections on the need to abandon the traditional North-South dichotomies prevalent in the field, to be committed to both academic quality and support for social justice globally, and to engage with global transformations rather than primarily changes in so-called "developing countries". 
Traditionally, development research has been part of an international system that includes policies, practices and organizations that focus on the improvement of the life of those residing in the Global South (Janus et al. 2015). Therefore, not only the practical but also the policy relevance of research is central. Development research is typically funded, at least partly, by Ministries of Foreign Affairs or national aid agencies from money allocated to international development cooperation. Thus research conducted is expected to make direct contributions to the goals of international and national development policies. In a similar vein, our research project received funding from a "Development Research Program", partly funded by the Finnish Ministry for Foreign Affairs of Finland and, consequently, we had to tackle the above-mentioned questions. While our primary aim was to engage with analysis that is not directly connected to any specific intervention, in each chapter we have reflected on the implications of our findings for potential future initiatives for strengthening citizenship.

However, the constant need to provide prescriptions and contribute to practice, directly and rapidly, sometimes jeopardizes both conceptual elaborations and empirical investigations. The field of development studies is famous for its changing "buzzwords" (Cornwall 2007), notions that circulate disconnected from their theoretical backgrounds, frequently adopted by development practitioners and researchers alike. In this study, we have attempted to avoid circulating the buzzwords of the system and, therefore, sought respite from theoretical embeddedness in philosophical pragmatism not prevalent in the field.

\section{Philosophical pragmatism: Intertwining theory and practice}

Pragmatism refers to a philosophical tradition explicated by scholars such as Charles Sanders Peirce (1839-1914), William James (1842-1910) and John Dewey (1859-1952). As the name indicates, pragmatism stresses the role of human practices in philosophy. Furthermore, one of the main starting points of early pragmatists was that the academic field of philosophy should take evolutionary theory seriously as well as other theories of modern science; John Dewey also developed a theory of social inquiry as a theoretical tool for engaging with social problems (e.g. Dewey 1935, 1-66; see also Addams 1902/ 2002). Dewey is often considered to be ahead of his time (Jones 2009, 137154; Leddy 2006/2016), and his ideas are still extensively used, debated and developed in philosophy and empirical research to address issues such as globalization (Narayan 2016), public administration (Evans 2000; Whetsell \& Shields 2011) and education (Wilson \& Waddington 2016, 89-94).

First, in this research project, pragmatism provided us with the conceptual means to take a stand on the issue of normativity. In philosophy, the concept of normativity, at the basic level, refers to "how thing ought to be" whereas its counterpart, descriptivity, refers to "how things are". From the pragmatist perspective, there is constant interaction - or entanglement - between facts, 


\section{Kontinen and Holma}

or how things are, and values, which direct the ideals of how things should be (Dewey 1929; Putnam 2002; Holma 2011). This implies that all human activity, including research, is embedded in certain values and normative ideas, which can, however, be revised in a joint inquiry. Pragmatism suggests that all theories, conceptualizations and belief systems are uncertain and liable to error, but that human beings may assess and improve these systems, in relation to both facts and values; in this assessment and improvement, a method of shared inquiry is crucial. The pragmatist framework thus also acknowledges that there can be multiple normative ideas about "what ought to be", and that it is possible to re-evaluate these ideas in interaction between different value perspectives and in the face of new empirical evidence. Inspired by these ideas, we embarked in a relatively non-normative way from the analysis of everyday perceptions, inquiring about the kinds of ideals of good citizenship people hold in different locations rather than starting with a definition of a "good citizen" from some existing theory of citizenship.

Second, pragmatism guided our understanding of the intertwined nature of theory and practice. One of the key ideas of pragmatism is that philosophy should engage with human practices. One side of the coin is that for pragmatism, a criterion of a good theory is that it helps in understanding and developing current practices. The other side of the coin is that a good theory should not be based merely on ideals but should be informed by actual practices. We perceived philosophical pragmatism to fit our purposes since it differs from so-called analytical philosophy in its stance towards practice and, therefore, could potentially be relevant to such a practice-focused field as development research. We wanted to explore the pragmatist framework in a field where critical social theories ranging, on the one hand, from Marx to Gramsci to Habermas, and from Foucault to post-structuralism, on the other, are extensively used to analyze inequalities and power in their material, discursive and epistemic forms. While we consider critical theories extremely relevant in this research field, we nevertheless suggest that pragmatism, with its particular understanding of practices and habits (Holma \& Kontinen, this volume), offers an additional and supplementary angle from which to interpret everyday lives and the potential for change initiated by them.

\section{Development practice: From civil society to strengthening of citizenship}

Eventually, we chose a general theme of citizenship as the focus of our inquiry. The issue of citizenship has emerged as central in development research, and the promotion of active citizenship has gained prominence in development practice (Cornwall \& Coelho 2006). This has been especially related to the mainstreaming of the Human Rights Based Approach (HRBA) in which citizens are encouraged to claim their rights. Notions such as empowerment (Kabeer 1999), citizen engagement (Gaventa \& Barrett 2012), social accountability (Hickey \& King 2016) and civic-driven change (Fowler $\&$ Biekart 2013) emphasize the importance of citizens' agency in taking an 
active role in changing their living conditions. The promotion of learning about one's rights and practices of mobilizing are important strategies to support active citizenship in development interventions conducted by NGOs and other civil society actors.

There are plenty of examples in which initial support from an NGO has led to change in citizens' stance towards the government and other stakeholders: for instance, in regard to the rights of people with disabilities (Abrese Ako et al. 2013), or gender equality (Phillips 2015). At the same time, however, the question of why citizens do not become active as a consequence of such initiatives has also been raised (Pettit 2016). Among the identified elements hindering transformation towards more active citizenship are challenges related to transmitting models of rights-based approaches and participatory technologies without sufficient sensitivity to existing patterns of acceptance of authority (Dorman 2014, 170), and a lack of acknowledgement of the prevalent civic habitus formed in long-term experiences of poverty and oppressive governance (Pettit 2016). Moreover, it has been pointed out that the direction of these aspirations is often based on certain Westerns models grounded on an ideal of the "individual, male and modern" citizen (Robins et al. 2008; Lazar 2013). Further, in authoritarian contexts people's group memberships and associated rights and obligations might not be first and foremost geared towards the state, while the modern notion of citizenship focuses on state-citizen relationships. The identity and belonging, rights and obligations which are significant to people often follow lines of ethnicity, kinship, religion and place of origin rather than nation states (Bøås \& Dunn 2013; Dorman 2014; Geshiere \& Jackson 2006). Consequently, investigating citizenship requires delving into local conceptualizations and lived experiences of belonging rather than embarking from any ready-made ideals of citizenship (Kabeer 2005).

In international development, the emphasis on active citizenship mostly relates to the broader goal of transforming the existing authoritarian governance models in the direction of democracy and good governance - the cornerstone of which is an active citizen ready for political participation (Lazar 2012). Democratization efforts and donor conditionalities have resulted in the establishment of regular elections in most African countries, but the consolidation of the desired model of liberal democracy has not been fully successful. As a consequence, African states have undergone a growing "democracy fatigue" (van de Walle 2012), establishing "competitive authoritarianism" (Cheeseman 2018) or hybrid regimes (Tripp 2010) that combine democratic institutions with authoritarian governance. Moreover, clientelistic relations and the realities of under-resourced states pose specific challenges for people's willingness to participate, for example, in initiatives based on the idea of deliberative democracy (Cornwall \& Coelho 2006). In such contexts, building local democracy and bottom-up citizenship by means of enhancing citizens' capacities - often through participation in locally-organized groups and associations not necessarily initially engaged with an explicitly political 
realm - plays an important role in societal development (Gaventa \& Barrett 2012; King 2015; Hickey \& King 2016). Consequently, when exploring how citizenship is learned, it is important to engage with the areas and spaces of participation which are significant and meaningful in the everyday life of the citizens, rather than limiting the focus only to those concerned with the "political".

Against this backdrop, we sought for a conceptualization of citizenship that allows the gap between ideal models and lived experiences to be addressed, and that captures the gradual processes of change in citizenship (Holma, Kontinen \& Blanken-Webb 2018). Inspired by pragmatism, we decided to conduct empirical research that would start with analysis of existing conceptualizations of citizenship, and the kinds of experiences from which they arose. Additionally, on the basis of philosophical pragmatism, we developed a conceptualization of citizenship as constructed in practices taking place in communities involved in a public, thus, in joint activities with an aim of taking care of shared issues. In these practices, citizenship habits are both acquired and reformulated, thus, learned. Circumstances of practices, referring to the institutionalized habits of state-citizen relationships and habits of people's organizing, connect local and everyday experiences to the historical continuum, affecting which practices become relevant and what kinds of habits are the most likely to be learned (Holma \& Kontinen, this volume).

\section{Methodological note: Collaborative dealing with uncertainties}

To realize the idea of the intertwined relationship of philosophy and practice in the course of an actual research project is far from an easy task. In the first seminar of our project in September 2015, one very renowned scholar in the field of philosophical pragmatism emphasized that pragmatist inquiry does not "begin with a theory vs. practice dichotomy but is always already practically relevant". We asked him what this implies for research practice and how we should conduct our collaborative study in order to engage in inquiry rather than simply applying selected concepts from philosophical pragmatism to empirical studies in Tanzanian and Ugandan realities. A bit surprisingly, his answer was that philosophical pragmatism is "practically relevant mainly in theory, not in practice". We wanted to go beyond this statement. Despite the scarcity of time and other resources, we set out to experiment with how principles of joint inquiry could guide our own process of knowledge production in research practice. Therefore, this book is the result of a continuous dialogue: first, between pragmatist philosophy and development research, and second, between Northern and Southern academics. During the process we learned to deal with uncertainties when it came to defining citizenship, developing detailed field methods and conducting analysis of the data. We continuously had to go beyond our own disciplinary manoeuvres, jargon and writing styles in order to be able to communicate and understand each other. 
At the beginning of the project, our main goal was to investigate encounters between NGOs and their beneficiaries in NGO projects that aimed to strengthen citizenship. Therefore, our first entry point for the actual empirical research in communities was to identify the Ugandan and Tanzanian NGOs whose encounters would be under scrutiny. However, gradually we wanted to distance ourselves somewhat from the NGOs in order to avoid perceptions that the research was about evaluating their project or assessing the impacts of their activity. Rather, we were interested to see if they played any significant role in the everyday life of the community members. However, we conducted interviews and workshops with the NGOs in order to discuss their perceptions of the ideal citizenship they would like to support through their programs.

We were also interested in local definitions of "citizenship". Therefore, the first round of interviews among community members focused on identifying arenas of participation meaningful for them and the interpretations of citizenship they articulated. In Tanzania, we were able to conduct a second round of interviews: first, to provide feedback on the results of the first round to community members, and second, to get more in-depth information on selected meaningful spaces of participation such as self-help and religious groups. The interviews in communities were conducted in local languages, and all the material was transcribed in the original form. The material collected during the GROW project and used in diverse chapters in this book is listed in Table 1.1, while the chapters by Alava as well as by Bananuka and John are based on individual PhD projects accomplished prior to joining the GROW team. Philosophical analysis of the selected concepts in pragmatism was conducted in parallel with the generation of research material from Uganda and Tanzania.

Our research project could not escape the much-debated power asymmetries in North-South relationships in development research (Melber 2015; Carbonnier \& Kontinen 2015). The usual preconditions applied: the funding was granted by a Northern funding agency, the Academy of Finland, with its own administrative requirements; the money to the Southern universities was transferred under conditions of detailed planning and reporting; the initial research proposal was designed mainly by the Northern scholars although commented on by the Ugandan and Tanzanian partners; and data collection was mainly the responsibility of the Southern partners. There were, however, attempts to counteract the traditional asymmetric research relationship. We conducted annual research seminars with the entire research team both in Finland and Africa where the project was redesigned in different stages; a Tanzanian postdoctoral researcher was employed in a Finnish university contrary to the standard practice of allocating the funding to young scholars from Northern universities; and the Southern researchers continuously engaged with analysis and writing the publications. Additionally, we were well aware of the debates criticizing the use of Western theories in making sense of African experience (Ndlovu-Gatsheni 2018). Without doubt, we are guilty of 


\section{Kontinen and Holma}

Table 1.1 The empirical research material collected in the GROW research project.

\begin{tabular}{lll}
\hline Time & Material on NGOs & Material on communities \\
\hline $\begin{array}{l}\text { November } \\
2016\end{array}$ & $\begin{array}{l}\text { Workshop in a Ugandan } \\
\text { NGO }\end{array}$ & \\
& $\begin{array}{l}\text { Interviews with the NGO } \\
\text { staff }\end{array}$ & \\
January 2017 & $\begin{array}{l}\text { Interviews in a Tanzanian } \\
\text { NGO }\end{array}$ & $\begin{array}{l}\text { Interviews in three villages in } \\
\text { Kondoa District in Tanzania } \\
\text { (n=20) }\end{array}$ \\
April 2017 & $\begin{array}{l}\text { Feedback workshop in } \\
\text { Ugandan NGO }\end{array}$ & \\
$\begin{array}{l}\text { March-May } \\
\text { 2017 }\end{array}$ & & $\begin{array}{l}\text { Individual interviews in rural areas } \\
\text { in Kiboga and Namutumba Dis- } \\
\text { tricts in Uganda (n=60) }\end{array}$ \\
May-July 2018 & & $\begin{array}{l}\text { Feedback meetings in study villages } \\
\text { in Kondoa District (n=2) } \\
\text { Individual and group interviews in } \\
\text { three villages in Kondoa District } \\
\text { (n=64), Tanzania }\end{array}$ \\
& & $\begin{array}{l}\text { Feedback meetings in two villages } \\
\text { in Kondoa District. }\end{array}$ \\
\hline July 2019 & &
\end{tabular}

once again using the theories of a "dead white man", rather than drawing from African theories of learning and citizenship; yet, at the same time, our collaborative and bottom-up research approach, embedded as it is in pragmatist concepts, enabled us to critique some of the "Western" theories applied in development research and practice, giving rise to new ideas of how potentially to develop theories on the basis of everyday African experiences. Moreover, we have included as much Tanzanian and Ugandan literature as possible, especially in the chapters concerning the contextual characteristics of the states (Alava et al.; Nguyahambi et al.).

\section{Structure and contributors}

The overall aim of the book is to offer insights into the everyday experiences of citizenship in Tanzania and Uganda. At the same time, we offer a novel theoretical perspective for development research, drawing from philosophical pragmatism. Supplementing the idea of liberal, active citizens willing to hold the state accountable, it highlights citizenship as a lived experience and stresses the incremental learning therein. The main objectives of the book are: a) to articulate a concept of citizenship based on philosophical pragmatism; b) to explore a variety of practices in which citizenship habits are formed and reformulated; and c) to reflect on the interaction between the ideals of transformation and actualization of incremental change in practice. Consequently, the book is divided into three sections, each providing different perspectives on the questions at hand. 
The first section anchors the main concepts used in the research in philosophical pragmatism. In their chapter, Holma and Kontinen articulate the concept of citizenship, in which the notions of practices, habits and circumstances intertwine. Rydenfelt engages with the concept of democracy, and provides a pragmatist conceptualization of democracy as social inquiry. Kauppi, Holma and Kontinen present the pragmatist notion of social intelligence, central to citizenship habits and their potential change, and reflect on its potential implications for development research.

The second section contextualizes the conceptual ideas in prevalent circumstances in Uganda (Alava et al., this volume) and Tanzania (Nguyahambi et al., this volume), and provides in-depth analyses of citizenship practices and habits in specific locations. Alava (this volume) then discusses subdued citizenship formed in the experience of violent state-citizens relations among the Acholi in northern Uganda. Ndidde et al. (this volume) continue with an account of gendered citizenship formed over decades in rural Uganda in Kiboga and Namutumba Districts. Nguyahambi and Kontinen (this volume) describe the ways in which the members of a religious community in rural Tanzania in Kondoa District make connections between Islamic morals and good citizenship. Kilonzo et al. (this volume) examine the formation of habits of contributing citizenship in the practices of self-help groups in the same area.

The third section discusses the intersection between transformative ideals and gradual changes in practices in participatory research and development interventions. Ahimbisibwe et al. (this volume), provide a critical reflection on their own research process, tackling the ideals of participatory research and its practical implementation. Kontinen and Ndidde discuss organizational learning in a Ugandan NGO as it endeavours to promote change in gender relations. In the same vein, Bananuka and John describe how the critical education initiatives of a Ugandan NGO were shaped by contextual forces. Finally, Nguyahambi and Chang'a provide an analysis of the model of social accountability monitoring (SAM), and an example of discrepancies between its ideals and practical implementation.

The final chapter by Kontinen and Holma provides conclusions concerning the three aims articulated, and reflects the lessons learned from this particular research process for development research and philosophical pragmatism.

\section{References}

Abrese Ako, M., Anyidoho, A. \& Crawford, G. (2013). NGOs, rights-based approaches and the potential for progressive development in local contexts: Constraints and challenges in northern Ghana. Journal of Human Rights Practice, 5(1), 46-74.

Addams, J. (2002). Democracy and social ethics. Urbana: University of Illinois Press. (Original work published 1902).

Alff, H. \& Hornidge, A.-K. (2019). 'Transformation' in international development studies: Across disciplines, knowledge hierarchies and oceanic spaces. In I. Baud, T. 


\section{Kontinen and Holma}

Kontinen \& S. von Itter (Eds.). Building development studies for the new millennium (pp. 141-162). Cham, Switzerland: Palgrave Macmillan.

Bøås, M. \& Dunn, K.C. (2013). Politics of origin in Africa: Autochthony, citizenship and conflict. London: Zed Books.

Carbonnier, G. \& Kontinen, T. (2015). Institutional learning in North-South research partnerships. Revue Tiers Monde, 1(221), 149-162.

Cheeseman, N. (Ed.). (2018). Institutions and democracy in Africa: How the rules of the game shape political developments. Cambridge: Cambridge University Press.

Cornwall, A. (2007). Buzzwords and fuzzwords: Deconstructing development discourse. Development in Practice, 17(4/5), 471-484.

Cornwall, A. \& Coelho, S. (2006). Spaces for change? The politics of participation in new democratic arenas. London: Zed Books.

Cowen, M. \& Shenton, R.W. (1996). Development doctrines. London: Routledge.

Crewe, E. \& Axelby, R. (2013). Anthropology and development: Culture, morality and politics in a globalized world. Cambridge: Cambridge University Press.

Dewey, J. (1929). The quest for certainty. In J.A. Boydston (Ed.). The later works of John Dewey (Volume 4, pp. 1-250). Carbondale: Southern Illinois University Press.

Dewey, J. (1935). Liberalism and social action. In J.A. Boydston (Ed.). The later works of John Dewey (Volume 11, pp. 1-66). Carbondale: Southern Illinois University Press.

Dorman, S.R. (2014). Citizenship in Africa. In E.G. Isin \& P. Nyers (Eds.). Routledge handbook of global citizenship studies (pp. 161-172). Abingdon: Routledge.

Evans, K.G. (2000). Reclaiming John Dewey: Democracy, inquiry, pragmatism, and public management. Administration \& Society, 32(3), 308-328.

Fowler, A. \& Biekart, K. (2013). Relocating civil society in a politics of civic-driven change. Development Policy Review, 31(4), 463-483.

Gaventa, J. \& Barrett, G. (2012). Mapping the outcomes of citizen engagement. World Development, 40(12), 2399-2410.

Geshiere, P. \& Jackson, S. (2006). Autochthony and the crisis of citizenship: Democratization, decentralization, and the politics of belonging. African Studies Review, 49(2), 1-7.

Green, M. (2012). Framing and escaping: Contrasting aspects of knowledge work in international development and anthropology. In S. Venkatesan \& T. Yarrow (Eds.). Differentiating development: Beyond and anthropology of critique (pp. 42-57). New York: Bergham Books.

Hickey, S. \& King, S. (2016). Understanding social accountability: Politics, power and building new social contracts. The Journal of Development Studies, 52(8), 1225-1240.

Hickey, S. \& Mohan, G. (Eds.). (2004). Participation: From tyranny to transformation? Exploring new approaches to participation in development. London: Zed Books.

Holma, K. (2011). The epistemological conditions of moral education: The notions of rationality and objectivity revisited. Educational Theory, 61(5), 533-548.

Holma, K., Kontinen, T. \& Blanken-Webb, J. (2018). Growth into citizenship: Framework for conceptualizing learning in NGO interventions in sub-Saharan Africa. Adult Education Quarterly, 68(3), 215-234.

Howell, J. \& Pearce, J. (2002). Civil society and development. Boulder, CO and London: Lynne Rienner Publishers.

Janus, H., Klingebiel, S. \& Paulo, S. (2015). Beyond aid: A conceptual perspective on the transformation of development cooperation. Journal of International Development, 27(2), 155-169. 
Jones, T.B. (2009). John Dewey: Still ahead of his time. In P.M. Jenlink (Ed.). Dewey's democracy and education revisited: Contemporary discourses for democratic education and leadership (pp. 137-156). Lanham, MD: Rowman \& Littlefield.

Kabeer, N. (1999). Resources, agency, achievements: Reflections on the measurement of women's empowerment. Development and Change, 30(3), 435-464.

Kabeer, N. (Ed.). (2005). Inclusive citizenship: Meanings and expressions. London: Zed Books.

Kontinen, T. \& Melber, H. (2015). Civil society, cooperation and development: Introduction to a special issue. Journal für Entwicklungspolitik - Austrian Journal of Development Studies, 31(1), 4-12.

King, S. (2015). Political capabilities for democratisation in Uganda: Good governance or popular organization building? Third World Quarterly, 36(4), 741-757.

Lazar, S. (2012). Citizenship quality: A new agenda for development? Journal of Civil Society, 8(4), 333-350.

Lazar, S. (2013). The anthropology of citizenship: A reader. Hoboken, NJ: WileyBlackwell.

Leddy, T. (2016, February). Dewey's aesthetics. (Original work published 2006, September). Retrieved from https://plato.stanford.edu/entries/dewey-aesthetics/

Melber, H. (2015). Knowledge is power - and power affects knowledge: Challenges for research collaboration in and with Africa. Africa Development, XL(4), 21-42.

Mitlin, D., Hickey, S. \& Bebbington, A. (2007). Reclaiming development? NGOs and the challenge of alternatives. World Development, 35(10), 1699-1720.

Narayan, J. (2016). John Dewey: The global public and its problems. Manchester: Manchester University Press.

Ndlovu-Gatsheni, S.J. (2018). Epistemic freedom in Africa. London: Routledge.

Olivier de Sardan, J.-P. (2005). Anthropology and development: Understanding contemporary social change. London: Zed Books.

Oswald, K., Leach, M. \& Gaventa, J. (2019). Engaged excellence in development studies. In I. Baud, T. Kontinen \& S. von Itter (Eds.). Building development studies for the new millennium (pp. 119-140). Cham: Palgrave Macmillan.

Pettit, J. (2016). Why citizens don't engage? Power, poverty and civic habitus. IDS Bulletin, 47(5), 89-102.

Phillips, R. (2015). How 'empowerment' may miss its mark: Gender equality policies and how they are understood in women's NGOs. Voluntas, 26(4), 1122-1142.

Putnam, H. (2002). The collapse of the fact/value dichotomy and other essays. Cambridge, MA: Harvard University Press.

Robins, S., Cornwall, A. \& von Lieres, B. (2008). Rethinking 'citizenship' in the postcolony. Third World Quarterly, 29(6), 1069-1086.

Schöneberg, J. (2019). Imagining postcolonial-development studies: Reflections on positionalities and research practices. In I. Baud, T. Kontinen \& S. von Itter (Eds.). Building development studies for the new millennium (pp. 97-118). Cham: Palgrave Macmillan.

Thomas, A. (2000). Meaning and views of development. In T. Allen \& A. Thomas (Eds.). Poverty and development: Into the 21st century (pp. 23-50). Oxford: Oxford University Press.

Tripp, A.-M. (2010). Museveni's Uganda: Paradoxes of power in a hybrid regime. Boulder, CO: Lynne Rienner Publishers. 


\section{Kontinen and Holma}

van de Walle, N. (2012). Conclusion: Democracy fatigue and the ghost of modernization theory. In T. Hagmann \& F. Reyntjens (Eds.). Aid and authoritarianism in Africa: Development without democracy (pp. 161-178). London: Zed Books.

Whetsell, T.A. \& Shields, P.M. (2011). Reconciling the varieties of pragmatism in public administration. Administration \& Society, 43(4), 474-483.

Wilson, T.S. \& Waddington, D.I. (2016). Introduction to section II: Dewey's living ideas. Educational Theory, 66(1-2), 89-94. 


\section{Part I}

\section{Concepts anchored in philosophical pragmatism}


$\Longrightarrow$ Taylor \& Francis

Taylor \& Francis Group

http://taylorandfrancis.com 


\title{
2 Practices and habits of citizenship and learning
}

\author{
Katariina Holma and Tiina Kontinen
}

\section{Introduction}

This chapter discusses the volume's theoretical underpinnings, which are derived from philosophical pragmatism. One of the key ideas of this research project has been to bring philosophical and empirical research into dialogue by following the principles of pragmatism. Pragmatism sees the relationship between theory and practice as bidirectional: all theories must be subjected to revision in light of practice but, at the same time, a crucial role of theories is to critique current practices. At the level of methodology this implies that theorizing must be tied to what people do. The second central feature of pragmatism is that human experience is a crucial starting point of inquiry; pragmatism is suspicious about universal solutions: theorizing should start from real-life contexts, which vary for cultural, historical and geographical reasons.

Our research began, on the one hand, with existing theorizations of citizenship and learning inspired by philosophical pragmatism and, on the other, the lived experiences of citizenship and learning in the various research contexts in Tanzania and Uganda. In addition to the broad conceptualization of citizenship as a legal status, participation and identity - widely discussed in both philosophy and development research - we particularly considered citizenship from the viewpoint of practices and learning from the viewpoint of reformulation of habits. The idea of citizenship as constructed in practices presented here is grounded in John Dewey's (1859-1952) concepts of the public, community and his theory of social nature of knowledge and action. It directs the focus to what people do in shared activities that relate to citizenship, as well as the ways and the arenas in which they interact with each other and with their environments. The concept of habit, in turn, refers to the "acquired predisposition to ways or modes of response" (Dewey 1922, 32). Habits are formed in experience, which the pragmatists understand as the interaction between the self and the environment (Hildreth 2012, 922-923). Habits and environments can change, and the conditions of such change are central in conceptualizing learning as the reformulation of habits. 
In what follows, we first provide a brief overview of the process that led to our definitions of the concepts of practice and habit. Initially, we had the idea of conducting research based on the concept of growth into citizenship, which we had developed by drawing on Dewey's theory of growth. As it turned out, this conceptualization had both benefits and limitations which related to the particular contexts and research phenomena under analysis. Second, based on the identified benefits and limitations, we describe the further developments of our framework by elaborating on our conceptualization of citizenship as constructed in practices, and learning as the reformulation of habits. We then reflect on the notion of circumstances in relation to citizenship habits and practices in the context of sub-Saharan Africa. In conclusion, we provide a summary of the definition of citizenship used throughout this volume.

\section{Growth into citizenship - advantages and limitations}

Our initial, broad aim was to provide a theoretical account of how one learns to be a citizen in various contexts in Tanzania and Uganda. We started the project by drawing theoretical notions from Dewey's work, suggesting the notion of growth into citizenship as a new theoretical approach to these contexts (Holma, Kontinen \& Blanken-Webb 2018). We explicated that Dewey's concept of growth is founded in the dynamics between three central elements: "habit", "disruption" and "aesthetic response", demonstrating that, according to this theory, habits channel daily practices and thoughts, and allow human beings to think and act efficiently and productively. People are not usually conscious of their habits in their everyday lives, but realize them when their ways of acting and thinking face a disruption. A disruption presented, for example, by a new situation, disorganizes existing habits, to which an individual can respond in many ways. The response, for its part, is aesthetic when it leads to the reformulation of habits in a way that enables further growth (ibid., 222-225).

Dewey's view combines his theory of the interplay between habits, disruptions and aesthetic responses with what could be called an anti-foundational but normative view of growth (Hildreth 2009, 796), which distinguishes growth from other versions of learning. Growth is anti-foundational in the sense it is not tied to any predefined ends; on the contrary, ends are always ends-in-view that depend on the context (Hildreth 2009, 795-796; Holma, Kontinen \& BlankenWebb 2018, 226). Dewey argues that predefined ends are actually fundamental obstacles to growth (ibid., 226; Dewey 1916, 107-108). This distinguishes growth from learning ideals which include a specific target: for example, views in citizenship education which entail predefined definitions, such as formulating the "active citizen" as a person who is motivated and capable of pursuing the aims of deliberative democracy or making explicit claims towards the power-holders. Nevertheless, the definition of growth is itself also normative in the sense that learning can only be defined as growth when it enables further growth and increases the ability to make change in one's environments (Nelsen 2016, 239; Holma, Kontinen \& Blanken-Webb 2018, 226). 
During the process of developing the conceptualization of growth into citizenship, in dialogue with real-life contexts of our research, we identified some benefits and some problems. The idea of not grounding normativity of growth in predefined ends but in context-dependent "ends-in-view" defined in joint negotiations, resonated with our idea that ideals of citizenship are something continuously defined and negotiated in contextual practices. However, we realized that the Deweyan normative stance of growth as a particular kind of learning confronted philosophical difficulties when brought into Tanzanian and Ugandan contexts. Whether a process of learning really amounts to growth, especially when it involves an increase in the ability to make change in one's environment, is so deeply dependent on circumstances that it seemed problematic to define something as growth or not growth based on Dewey's normative criteria. Consequently, we realized that the proposed framework needed serious sensitivity to larger societal dimensions. Although Dewey $(1922,76-78)$ discusses, at a general level, the difficulty of rapid social change in the context of institutions that embody habits, in our view his theory does not pay sufficient attention to the contextual content of the circumstances of practices where the citizenship is constructed.

Furthermore, at the level of conducting empirical research it proved difficult (or even impossible) to track processes of growth, whether from the narratives of people, by conducting surveys or through observation. Such processes are hard to observe in everyday life within the limited time allocated for fieldwork. Moreover, in regard to interviews, rare is the occasion when someone is both aware of, and able to articulate, the process whereby existing habits had faced disruption, and then been reformulated to expand the possibilities of action and enable further growth.

Based on these observations, we shifted the focus of our experiment away from growth as we became increasingly aware of the importance of understanding the nature of habits and the process of their acquisition in the course of everyday practices. Moreover, we decided to pay more attention to the circumstances of the practices. Ultimately, our attempt to bring into dialogue the conceptualization of growth into citizenship and the real-life situations of our research contexts led us to focus more on what we now term practices, habits and circumstances.

\section{Citizenship as constructed in practices}

In developing our approach to citizenship as constructed in practices, our starting point was the Deweyan idea of citizenship as manifesting in different kinds of communities where people participate in their everyday lives (Dewey 1927, 238-366). The proposed notion of citizenship as constructed in practices differs from the common term of "citizenship practices" (Wiesner et al. 2018) used in reference to activities such as voting or deliberating on public decision making, which are closely connected either to ideas of citizenship as a status or active participation in public affairs. The notion suggested here 
rather refers to any kind of practice where people participate in their everyday lives and which constitute their lived experiences of citizenship. Ideas related to citizenship as lived experience are, nevertheless, not new either to recent citizenship studies or development research. Therefore, in this section, we elaborate on our conceptualization vis-á-vis some current theoretical tendencies in these fields.

In her entry, "Citizenship", in the Stanford Encyclopedia of Philosophy, Dominique Leydet (2017) divides the contemporary discussion of the notion of citizenship into three dimensions: 1) "legal status, defined by civil, political and social rights"; 2) political agency, that is, citizens actively participating in a society's political institutions; and 3) membership in a community that "furnishes a distinct source of identity". These three dimensions relate to the traditional distinction between theoretical approaches to citizenship in the political sciences: liberalism, republicanism and communitarianism, with liberalism focusing on rights, republicanism stressing active participation, and communitarianism paying attention to aspects of belonging and identity (Björk et al. 2018, 17; Gaventa 2004). Recent debates in citizenship studies, however, have argued for an "expansion of the concept of citizenship" (Isin \& Nielsen 2008, 1; Isin \& Nyers 2014, 8). This refers, first, to distancing the concept of citizenship from the traditional notion based on the civil, political and social rights of an individual vis-á-vis the state (e.g. Marshall 1950), and the inclusion of sexual, cultural and environmental rights; and second, redefinition of the political communities from whom these rights are claimed and exercised to include more local communities on the one hand, and regional (e.g. European Union) and global entities, on the other. Therefore, a "recentering" and "thick contextualization" of the concept has been suggested on the grounds that contemporary citizenship is always related to specific "political projects, particular social contexts, and distinctive cultural configurations" (Clarke et al. 2014, 9).

In the field of development research, the rights-based view resonating with the liberal perspective has been prevalent, accompanied by republican ideas of participation and engagement, as well as more radical views on transformative citizenship (Hickey \& Mohan 2004). However, there have also been calls for more nuanced conceptualizations of citizenship, starting from the experiences and perspectives of the people concerned rather than from theoretical frameworks, especially but not exclusively with regard to citizenship as membership and identity. ${ }^{1}$ For example, Kabeer $(2005,3)$ emphasizes the importance of investigating how "people define themselves in different contexts, how they see themselves in relation to others, and what this implies for their understanding of citizenship in the world as they know it" (emphasis added). Here, the focus should be on the meanings and experiences of citizenship in "different parts of the world". In a similar vein, the anthropology of citizenship (Lazar 2012; 2013; Lazar \& Nuijten 2013) has argued for focusing on experienced citizenship rather than ideal theoretical models of it. 
Thus, our pragmatist starting point was to explore what we call the "lived experiences of citizenship", is in line with recent debates in citizenship studies, development research and the anthropology of citizenship. Following Clarke et al. (2014, 141), who suggest a focus on "communities of citizenship", we examined citizenship in social contexts, starting with significant and meaningful arenas. These were identified based on interviews wherein participants were first asked to identify groups and communities in which they participate, and then to describe their perceived significance and the actual ways they took part. The groups comprised, for instance, local communities through residence, religious communities, self-help groups, economic associations and ethnic cultural groups (Nguyahambi et al. 2017). Moreover, in line with the arguments presented in development studies, pragmatist notions lead us to attend to people's own experiences and definitions of citizenship. These largely revolved around the idea of citizenship as membership and identity in the cases analyzed, whereas citizenship as a legal status was discussed mainly in relation to a voter's identification card. It also became apparent that participation was mostly geared towards the meaningful communities mentioned above; participation in what is traditionally referred as the public sphere that is, being active in local politics, or engaging in political claim making (Gaventa 2004) - was not so prevalent within the contextualized experiences among our research participants.

Against this backdrop, we argue that Deweyan pragmatism enables an expanded and contextualized conceptualization of citizenship. In order to explore more deeply what this theory implies, Dewey's notions of the public and community, as well as his theory of the social nature of human knowledge and activities are central. In his use of public, Dewey refers to people jointly taking part in activities of different kinds with the aim of taking care of shared issues; public thus refers to the sphere of activity wherein various communities go about their business of taking care of shared issues. A community, on the other hand, refers to the group of people participating in this kind of joint activity (Dewey 1927, 278). In one larger society, there are many different kinds of communities related to different kind of shared issues and joint activities, which can also be related to each other; concomitantly, one person can be a member of many communities. As Melissa Williams writes:

[W]e find ourselves in webs of relationships with other human beings that profoundly shape our lives, whether or not we consciously choose or voluntarily assent to be enmeshed in these webs. What connects us in a community of shared fate is that our actions have an impact on other identifiable human beings, and other human beings' actions have impact on us.

(Williams 2003, 229)

Dewey's framing of the public does not involve a public / private dichotomy; his philosophy rejects the idea that only public sphere activities can be 


\section{0}

Holma and Kontinen

considered citizenship-related, and stresses the intertwined nature of the two spheres when participating in different kinds of communities taking care of shared concerns (Dewey 1927, 235-253). This view has proved useful in analyzing the empirical contexts of our research, as these dimensions are often intertwined in peoples' everyday lives; one also acquires important citizenship habits in the sphere that some other theories consider private. Dewey's formula does not include this dichotomy because his theorizations of citizenship do not set out from state-level democratic arrangements but, rather, begin with the notion of community. From this starting point, citizenship is also seen as participation in what are sometimes considered private sphere activities (like family life), daily work and duties, and other activities related to the arts, science and so on (ibid., 253).

This approach, that of citizenship constructed in practices, is further enriched by Dewey's suggestion that human knowledge and action are fundamentally social (Dewey 1916, 304; 1934, 251; 1938a, 482; 1938b, 22; Kauppi, Holma \& Kontinen, this volume). Thus, rather than thinking about citizenship in relation to individual identity, action or choice, it should be envisaged along the lines of joint and shared activities. Dewey's thinking is especially compatible with the overall idea of the primacy of the community over the "individual" when it comes to citizenship in Africa. As, for instance, Englund $(2004,3)$ argues, in the historically specific modes of belonging in Africa, individual citizenship is "merely one instance among many of claiming recognition" and, therefore, any theoretical framework guiding empirical investigation should not start only with the idea of the individual citizen.

Another important difference from other prevalent citizenship theories is that our notion does not draw a sharp distinction between political and social activities. For example, Isin and Nielsen $(2008,2)$ distinguish between social practices and citizenship acts, with the latter referring to collective or individual deeds that in some way "instantiate ways of being that are political". In contrast, we, like Dewey, think that the political is so deeply rooted in the social that a strong distinction appears artificial. Dewey's views resonate with the distinction made between "broad" and "narrow" conceptions of the "political", something also stressed by feminist scholars of citizenship (Lister 1997, 25). The narrow conception refers to traditional participation in political institutions, while the broad regards the public, private and even intimate spheres as political. In the broad view, "public sphere" does not only refer to political institutions, but encompasses "the myriad of voluntary associations of civil society, most particularly the kinds of campaigning and community groups" (ibid., 29).

The broad conception of "political" has especially made women's invisible citizenship actions visible, but it can be also understood as more general basis for broad notion of citizenship. Communitarian frameworks argue that "citizenship activities" are those that maintain the community and its "shared beliefs and values" (Voet 1998, 10), rather than only consisting of overtly political activities of claim making. In a similar vein, Clarke et al. $(2014,132)$ 
point out that citizenship occurs "in the variety of daily, routine or more exceptional practices of citizenship across a diversity of levels, sites and places that are differently connected". Therefore, Dewey's criticism of the private /public distinction and his wide conceptualization of public affairs together offer a contribution to these debates by highlighting that not all practices where citizenship is constructed, are political in the narrow sense. Therefore, in addition to enhancing the view of citizenship as membership, the Deweyan perspective expands the understanding of citizenship as participation in any public affairs, which enables the examination of citizenship in a context relevant to people's experiences. The downside of this, however, is that considering participation in any public affairs or in solving social problems as the practice of citizenship can all together mask the political dimension related to state-citizen power relations, or the struggle over hegemony of different interests in the course of negotiation (Holma \& Kontinen 2015).

\section{Habits and learning}

One of our aims in the research process was to gain a new understanding of how citizenship is learned. In the beginning, we identified two challenges in contemporary conceptualizations of learning in regard to educational interventions geared to fostering "active citizenship" in international development (Holma, Kontinen \& Blanken-Webb 2018). First, while a wealth of learning approaches focus on transformative learning (Skinner et al. 2016), there is a need for a conceptualization of learning that is sensitive to gradual changes, incremental learning and obstacles to learning (Holma, Kontinen \& BlankenWebb 2018, 219-220). Second, in contrast to one-off training approaches, there is a need for both theoretical and practical approaches to understanding learning as embedded in everyday practices (ibid., 220-222). In order to address these challenges, we based our exploration of learning on the pragmatist concept of habit.

In general, all action and thinking is channelled through habits, which are not necessarily observable acts; rather, they are "predispositions to act" in a certain way in certain situations (Dewey 1922, 32). Habits are formed in a particular cultural and social context (Dewey 1927, 334-335) and are ways of thinking and acting that one has consciously or unconsciously learned in existing material and social circumstances. They are not something of which one is usually consciously aware; quite the contrary, in everyday life, habits are mostly unquestioned. Habits are both things that cannot be escaped, yet, at the same time, can be changed under suitable conditions. In Dewey's words: "The organic structure of man entails the formation of habit, for, whether we wish it or not, whether we are aware of it or not, every act effects a modification of attitude and set which directs future behavior" (Dewey 1927, 334-335).

The Deweyan notion of experience may be useful in understanding the nature of habits as well as the process of their formulation. Human experience 


\section{Holma and Kontinen}

can be described as an interaction between the environment and the self. The environment involves both material and social reality, including human activities, and it is in this interaction that habits are formed; however, it is possible to change both the self and environments (Hildreth 2012, 922-923), with changes in one resulting in changes in the other, while both existing habits and the environments can expand or narrow the possibilities of change. The self, in this view, does not refer to an isolated individual, but is, as Hildreth $(2012,922)$ puts it, "habitual and social".

The concept of habit is central to conceptualizing learning at many different levels; almost all human activity has to be learned, individuals learn new habits both consciously and unconsciously, and habits may change quite radically, on reflection, when they confront a disruption. However, habits do not change easily. The concept of habit provides a way to theorize around two crucial questions in development research: why changing citizenship practices through interventions is so difficult (Pettit 2016), and how a change of habits might be triggered by presenting adequate disruptions to current ways of thinking and acting. The following quotation describes one reason why "citizenship habits", embedded in politically, morally and culturally formed opinions, may be especially difficult to change:

Habits of opinion are the toughest of all habits; when they have become second nature, and are supposedly thrown out of the door, they creep in again as stealthily and surely as does first nature. And as they are modified, the alteration first shows itself negatively, in the disintegration of old beliefs, to be replaced by floating, volatile and accidentally snatched up opinions. [. . .] In social and human matters, especially, the development of a critical sense and methods of discriminating judgment has not kept pace with the growth of careless reports and of motives for positive misrepresentation.

(Dewey 1927, 336-337)

From the pragmatist point of view, learning as a reformulation of habits is not primarily an individual but a social phenomenon. In reference to our discussion of the social nature of intelligence in pragmatism (Kauppi, Holma \& Kontinen, this volume), learning as both the acquisition and reformulation of habits takes place in interaction with others and, moreover, in an active relationship with both the social and the material environment (Miettinen 2006). In the context of learning citizenship, the environments that have constituted political circumstances are also relevant, in addition to local practices. Even if considerable learning of citizenship habits takes place in the course of local practices that revolve around public affairs and social problems, these practices interact with historically formed state-citizenship constellations and institutionalized habits that can both expand or narrow the directions of learning. 


\section{Circumstances of practices and habits of citizenship in sub-Saharan Africa}

Pragmatism stresses the need for theorization to start from practice, from what people do. There are different interpretations in pragmatism about the role and nature of practices in theorizing but the main idea is that theory and practice are "responsive to each other in an ongoing interaction" (e.g. Talisse 2005, 98). This springs from one of the most essential ideas of pragmatism, fallibilism (Peirce 1934, 135-189), meaning that all our beliefs, perceptions and theories are liable to error, and implying that all theories must be submitted to critique and revision; one important source of the former is practice. The other side of the coin, however, is that one role of theorizing is to critique current practices.

As a methodological starting point, we found this pragmatist idea relevant in terms of the concept of citizenship, especially as citizenship (almost always) has a normative element; its definitions involve a normative dimension of what citizenship should ideally be. Philosophical accounts of citizenship may be idealistic in the sense that they are constructed by philosophers with little connection to the everyday life about which they are theorizing, and therefore, have insufficient reflection on the realizability of ideals. Yet, although the very point of an ideal is that it will not be fully realized, it must nevertheless be something which can guide thought, feeling and action (Huhtala \& Holma 2019, 175; Jaggar 2014, 35). In some cases an ideal can be suited to one context, but faces the problem of being too distant from real-life practices in another. In order to take a critical stance on either kind of ideal, we focused on actual citizenship practices and the habits acquired and reformulated in these particular practices, from a nonnormative position. From there we followed Talisse's $(2005,98)$ statement that "responsible theorizing, especially about political matters, must remain closely tied with what we do".

Practices are located and habits developed within particular circumstances, and a change of habits goes hand in hand with the change in circumstances. In Dewey's words, they depend "upon the environment inherited from our forerunners" and "incorporate objective conditions in themselves" (Dewey 1922, 19). During our research project it became evident that the historically evolved characteristics of sub-Saharan African experiences of citizenship differ so crucially from, for instance, those of the United States and Europe, that these characteristics deserve closer attention in theory building. For example, in contemporary theoretical debates, the need to expand the concept of citizenship has often been related to the changing "realities of the modern pluralistic society" (Kymlicka \& Norman 2000, 8). The argument is that the goals of citizenship and the means of promoting it should increasingly take into account ethnic and religious diversity, including new minorities resulting from immigration. In contrast, for many of the sub-Saharan countries, this has been a normal situation for centuries. Different ethnic groups, languages 


\section{4}

Holma and Kontinen

and religions co-existed long before the establishment of nation states and continue to play an important role in people's experiences of identity and belonging; indeed, our own empirical investigations demonstrated that ethnic, linguistic and religious plurality was part of the everyday life of citizens, and constituted the main arenas of participation and identity.

African studies literature tends to suggest that African politics "poses formidable barriers to active citizenship" (Bratton 2013,3). Taking into account the role played by the colonial and post-colonial history of state formation in the constitution of citizenship, Chabal $(2009,47)$ argues that Africans are simultaneously treated by the state as subjects with minimal power, clients constantly establishing reciprocal relationships with "Big Men" and citizens (at least when it comes to the act of voting). Moreover, as long as the state does not provide space for participation or sufficient social protection (Green 2012) there is a need to seek them from, and therefore identify with, spheres of clientelism, ethnicity and religion. Chabal $(2009,12)$ goes so far as to claim that the African state - and thus citizenship - necessarily reflects the patrimonial nature of local politics, wherein the state is not institutionally functional. Instead of the state, the politics of belonging are geared toward kin, ethnic groups and reciprocal neo-patrimonial networks, which all revolve around a notion of obligation rather than rights, power hierarchy rather than equality (ibid., 2009). Moreover, some African studies scholars (Bøås \& Dunn 2013; Geshiere 2009) emphasize autochthony (being born from the soil), the idea that one is entitled to belong because of ancestral rights to land gained by "being there first" - the claim being "this in ours because we were here first" - linking people's identity to space and location. This became evident in our empirical exploration, as people in rural areas quite routinely spoke of "citizenship" in terms of residence in a certain location (Ahimbisibwe et al., this volume). Taken together, insights drawn both from the African studies literature and our own empirical work emphasize the importance of paying rigorous attention to environments and circumstances when using a pragmatist approach to citizenship.

\section{Conclusions}

In this chapter, we have provided a background for the methodological principles we have followed, and a conceptual contextualization of the notion of citizenship and learning as defined in this volume. We started with the idea of taking seriously two key ideas of pragmatism: valuing human experience as an important source of knowledge, and beginning our theorizing about social matters with what people actually do.

Based on philosophical pragmatism, we also elaborated on the notion of citizenship as constructed in practices. Our interpretation is based on Dewey's concepts of public and community, where public is the sphere where people attend to shared issues by participating in various communities. We suggested that the viewpoint of practices to citizenship enables the analysis of 
citizenship in all its three dimensions - legal status, participation and membership - especially helping to achieve a broader understanding of participatory and membership dimensions. This is mainly because citizenship as interpreted in this chapter do not necessary revolve around politics and claim making, but include different kinds of joint activities through which people address shared issues.

Our approach to learning is based on a pragmatist interpretation of the concept of habit. Broadly speaking, habits are people's consciously or unconsciously accepted dispositions to act and think. The acquisition and reformulation of habits can be conceived of as learning, which may happen either unconsciously or as a reflective response to disruption. By participating in the public in various communities, people acquire habits which can be utilized in other practices, including the arenas of citizens' engagement and citizenship acts of rights claiming. We also pointed out that citizenship habits and practices are formed in interaction with environments and circumstances, and, therefore, reflect the particular context of sub-Saharan Africa.

In conclusion, the definition we provided, based on pragmatism, understands citizenship as constructed in practices taking place in communities involved in a public, thus, in joint activities with an aim of taking care of shared issues. In these practices, citizenship habits are both acquired and reformulated, thus, learned. Circumstances, referring to the institutionalized habits of state-citizen relationships and habits of people's organizing, connect local and everyday experiences to the historical continuum, affecting which practices become relevant and what kinds of habits are the most likely to be learned. This conceptualization will guide the analysis in the empirical chapters of this volume engaging with different practices and citizenship habits learned in a variety of local contexts.

\section{Note}

1 For example, the extensive research conducted in the Center on Citizenship, Participation and Accountability in the Institute of Development Studies, Sussex, in 2000-2010, elaborated on a range of understandings of citizenship in the development context. The resulting book series, Claiming Citizenship (Zed Books), aims to challenge liberal understandings and "give a more robust understanding of citizenship as a multidimensional concept, which includes the agency, identities and actions of the people themselves" (Gaventa 2005, xii).

\section{References}

Ahimbisibwe, K.F., Ndidde, A.N. \& Kontinen, T. (2019). Participatory methodology in exploring citizenship: A critical learning process. In this volume.

Björk, A., Kivistö, H.-M., Mäkinen, K. \& Wiesner, C. (2018). Theorizing citizenship. In C. Wiesner, A. Björk, H.-M. Kivistö \& K. Mäkinen (Eds.). Shaping citizenship: A political concept in theory, debate and practice (pp. 17-20). New York: Routledge. 


\section{Holma and Kontinen}

Bratton, M. (Ed.). (2013). Voting and democratic citizenship in Africa. Boulder, CO: Lynne Rienner Publishers.

Bøås, M. \& Dunn, K. (2013). Politics of origin in Africa: Autochthony, citizenship and conflict. London: Zed Books.

Chabal, P. (2009). Africa: The politics of smile and suffering. London: Zed Books.

Clarke, J., Coll, K., Dagnino, E. \& Neveau, C. (2014). Disputing citizenship. Bristol: Policy Press.

Dewey, J. (1916). Democracy and education. In J.A. Boydston (Ed.). The middle works of John Dewey (Volume 9, pp. 1-370). Carbondale: Southern Illinois University Press.

Dewey, J. (1922). Human nature and conduct: An introduction to social psychology. In J.A. Boydston (Ed.). The middle works of John Dewey (Volume 14, pp. 1-230). Carbondale: Southern Illinois University Press.

Dewey, J. (1927). The public and its problems. In J.A. Boydston (Ed.). The later works of John Dewey (Volume 2, pp. 235-372). Carbondale: Southern Illinois University Press.

Dewey, J. (1934). Art as experience. In J.A. Boydston (Ed.). The later works of John Dewey (Volume 10, pp. 1-453). Carbondale: Southern Illinois University Press.

Dewey, J. (1938a). Logic: The theory of inquiry. In J.A. Boydston (Ed.). The later works of John Dewey (Volume 12, pp. 1-528). Carbondale: Southern Illinois University Press.

Dewey, J. (1938b). Experience and education. In J.A. Boydston (Ed.). The later works of John Dewey (Volume 13, pp. 1-62). Carbondale: Southern Illinois University Press.

Englund, H. (2004). Introduction: Recognizing identities, imagining alternatives. In H. Englund \& F. Nyamnjoh (Eds.). Rights and the politics of recognition in Africa (pp. 1-29). London: Zed Books.

Gaventa, J. (2004). Towards participatory governance: Assessing the transformative potentials. In S. Hickey \& G. Mohan (Eds.). Participation: From tyranny to transformation? Exploring new approaches to participation in development (pp. 25-41). London: Zed Books.

Gaventa, J. (2005). Foreword. In Kabeer, N. (Ed). Inclusive citizenship. Meanings and expressions (pp. xii-xiv). London: Zed Books.

Geshiere, P. (2009). The perils of belonging. Autochthony, citizenship, and exclusion in Africa and Europe. Chicago, IL: The University of Chicago Press.

Green, M. (2012). Co-producing inefficient states: Social knowledge, social policy and social citizenship in Africa and in development (ESID Working Paper No 14). Retrieved from www.effective-states.org/wp-content/uploads/working_papers/final-p dfs/esid_wp_14_green.pdf

Hickey, S. \& Mohan, G. (2004). Towards participation as transformation: Critical themes and challenges. In S. Hickey \& G. Mohan (Eds.). Participation: From tyranny to transformation? Exploring new approaches to participation in development (pp. 3-24). London: Zed Books.

Hildreth, R.W. (2009). Reconstructing Dewey on power. Political Theory, 37(6), 780-807.

Hildreth, R.W. (2012). John Dewey on experience: A critical resource for the theory and practice of youth civic engagement. Citizenship Studies Volume, 16(7), 919-935.

Holma, K. \& Kontinen, T. (2015). The rocky road of growth into contemporary citizenship: Dewey, Gramsci, and the method of democracy. Studier i Padagogisk Filosofi, 4(2), 24-37. 
Holma, K., Kontinen, T. \& Blanken-Webb, J. (2018). Growth into citizenship: Framework for conceptualizing learning in NGO interventions in sub-Saharan Africa. Adult Education Quarterly, 68(3), 215-234.

Huhtala, H.-M. \& Holma, K. (2019). Education of moral beings: The distortion of Habermas' empirical sources. Ethics and education, 14(2), 171-183.

Isin, E.F. \& Nielsen, G.M. (Eds.). (2008). Acts of citizenship. London: Zed Books.

Isin, E.F. \& Nyers, P. (2014). Introduction: Globalizing citizenship studies. In E.F. Isin \& P. Nyers (Eds.). Routledge handbook of global citizenship studies (pp. 1-11). London: Routledge.

Jaggar, A.M. (2014). Designing realistic educational utopias using (mainly) non-ideal theory. In M. Moses (Ed.). Philosophy of education yearbook (pp. 25-36). Urbana, IL: Philosophy of Education Society.

Kabeer, N. (Ed.). (2005). Inclusive citizenship: Meanings and expressions. London: Zed Books.

Kauppi, V.-M., Holma, K. \& Kontinen, T. (2019). John Dewey's notion of social intelligence. In this volume.

Kymlicka, W. \& Norman, W. (Eds.). (2000). Citizenship in diverse societies. Oxford: Oxford University Press.

Lazar, S. (2012). Citizenship quality: A new agenda for development? Journal of Civil Society, 8(4), 333-350.

Lazar, S. (2013). Introduction. In S. Lazar (Ed.). The anthropology of citizenship: A reader (pp. 1-22). Chichester: Wiley Blackwell.

Lazar, S. \& Nuijten, M. (2013). Citizenship, the self, and political agency. Critique of Anthropology, 33(1), 3-7.

Leydet, D. (2017, July 17). Citizenship. In Stanford Encyclopedia of Philosophy. (Original work published 2006, October 13). Retrieved from https://plato.stanford.edu/ entries/citizenship/

Lister, R. (1997). Citizenship: Feminist perspectives. New York: Palgrave.

Marshall, T.H. (1950). Citizenship and social class: And other essays. Cambridge: Cambridge University Press.

Miettinen, R. (2006). Epistemology of transformative material activity: John Dewey's pragmatism and cultural-historical activity theory. Journal for the Theory of Social Behaviour, 36(4), 389-408.

Nguyahambi, A., Kontinen, T., Kilonzo, R. (2017, August). Exploring experienced citizenship in Tanzania. Paper presented in (Un)Making Europe: Capitalism, Solidarities, Subjectivities. Conference of European Sociological Association. Athens, Greece.

Nelsen, P.J. (2016). Growth and resistance: How Deweyan pragmatism reconstructs social justice in education. Educational Theory, 66(1-2), 231-244.

Peirce, C.S. (1934). Collected papers of Charles Sanders Peirce, Volume 5: Pragmatism and pragmaticism. C. Hartshorne \& P. Weiss (Eds.). Cambridge, MA: Harvard University Press. (Original work published 1868).

Pettit, J. (2016). Why citizens don't engage? Power, poverty and civic habitus. IDS Bulletin, 47(5), 89-102.

Skinner, A., Baillie Smith, M., Brown, E. \& Troll, T. (Eds.). (2016). Education, learning and the transformation of development. London: Routledge.

Talisse, R.B. (2005). Democracy after liberalism: Pragmatism and deliberative politics. New York: Routledge.

Voet, R. (1998). Feminism and citizenship. London: Routledge. 


\section{Holma and Kontinen}

Wiesner, C., Björk, A., Kivistö, H.-M. \& Mäkinen, K. (Eds.). (2018). Shaping citizenship: A political concept in theory, debate and practice. New York: Routledge.

Williams, M.S. (2003). Citizenship as identity, citizenship as shared faith, and the functions of multicultural education. In K. McDonough \& W. Feinberg (Eds.). Citizenship and education in liberal-democratic societies: Teaching for cosmopolitan values and collective identities (pp. 208-247). New York: Oxford University Press. 


\title{
3 Pragmatism, social inquiry and the method of democracy
}

\author{
Henrik Rydenfelt
}

\section{Introduction}

Democracy is difficult to define. This is in part due to the fact that the word has almost become an automatic way of denoting a correct or acceptable form of national governance. Most governments and political systems profess to be democratic although whether they are often remains a hotly debated issue, making it clear that any limited set of conditions prescribing truly democratic governance may be defeated by counterexamples. Universal suffrage will not suffice if political opposition is systematically suppressed or citizens do not practically have the opportunity to exercise their right to vote. The constitutional separation of powers and various checks and balances will not equal "democracy" unless their operation serves the central aspirations of democratic societies, such as accountability, legitimacy and the basic goods of freedom and relative equality. Democracy, in a word, is an ideal rather than an actual state of affairs already attained; accordingly, philosophical accounts of democracy mostly outline ways in which our systems of governance should be designed, implemented and participated in, rather than describing the operations of any actual state or jurisdiction.

By and large, contemporary philosophical accounts of democracy address three types of issues. The first pertains to the justification, preferability and legitimacy of a democratic form of governance. Is democracy better than its alternatives, and is it so to everyone? What do we say to those who would rather be subject to a non-democratic form of governance? A second issue concerns the nature of democratic citizenship and the extent to which citizens can be expected to make informed choices when participating in public processes. This issue is especially pertinent when philosophers claim that decisions made by way of a democratic procedure are better than those produced by alternative systems of governance. Finally, a third set of issues concerns the setup of a democratic society. Here the questions concern the procedures, constitution and institutions that a democratic society should entail, as well as the nature of citizen representation in processes of decisionmaking, including different forms of direct and representational democratic settings. 


\section{Rydenfelt}

Many philosophers have proposed that the tradition of philosophical pragmatism offers a unique perspective on democracy and the role of citizens. In what follows, I discuss one pragmatist view of democracy and democratic citizenship that is grounded in John Dewey's view of social inquiry, contrasting it with two alternative visions of democracy. The first of these alternatives, sometimes critically dubbed élitist democracy, views democracy as a competition between political and expert élites representing citizens in the political process; here, the central democratic practice of citizens is voting in recurring elections. The second vision is deliberative democracy, where citizens are expected to engage in rational discourse and arrive at a reasoned consensus as to the best decisions. Instead of voting, the central practice is participation in the form of public deliberation. Although pragmatist views have been likened to and identified with the deliberative account, I argue that key differences in the two perspectives have largely been overlooked. The pragmatist approach to democracy as social inquiry is not equivalent to deliberation. However, as I point out, this difference entails that the pragmatist must give an account of why such inquiry should be understood as democratic; in particular, the pragmatist must address and explain the role of citizens in its practice.

\section{Élitism, deliberative democracy and pragmatism}

As a descriptive term, and very broadly speaking, democracy means equality in group decision-making: everyone has an equal chance to influence a decision affecting the group, at least at some point or juncture. Central to the development of contemporary Western democracy is the family of views in political philosophy often lumped together as liberal democracy. These views emphasize the rights and freedoms of individuals, which the state is expected both to respect and uphold, and equality among individuals with respect to these rights. However, in Western democracies, decisions are made by expertinformed political élites, and citizen participation is largely limited to the selection of representatives by voting in recurring elections. Joseph Schumpeter famously codified this élitist form of democracy as the "institutional arrangement for arriving at political decisions in which individuals acquire the power to decide by means of a competitive struggle for the people's vote" $(1950,269)$. In this view, democracy is the marketplace for competing groups of political professionals and experts, and the main - or only - role for citizens is to vote in elections where the successes and failures of political leaders are assessed. The connection between political decision-making and the citizen is representation, and the central democratic practice is voting (see Held 1987; Whipple 2005).

In part as a reaction to such élitism, proponents of a deliberative view of democracy demand the participation of citizens rather than their mere representation by experts. The background of deliberative democracy is a central concern of the liberal tradition: the legitimacy of governments and the use of state power, which - beginning with John Locke (1689/1988) - liberals have 
usually predicated on the acceptability of the government or its decisions to the governed individual or citizen. This notion of legitimacy influenced the work of John Rawls who, in A Theory of Justice (1971/1999), aspired to lay the foundations of a democratic society in basic principles which would be (rationally) acceptable to all citizens, despite their differing interests and incompatible beliefs. Rawls's work sparked renewed interest in political philosophy, including an industry of criticism of the Rawlsian project, such as the so-called communitarian critiques (e.g. Walzer 1983) and less consensusoriented views of democracy (e.g. Mouffe 2013).

The concern with legitimacy, as well as Rawls's arguments that some principles are acceptable to all "reasonable" citizens, inspired a new understanding of the central processes of democratic decision-making and the role of citizens. Together with increasing demands for public participation in political decision-making, contemporary thinkers such as Jürgen Habermas (1990), Rawls (1996) and Joshua Cohen (1989) proposed that the legitimacy or justification of political decisions depends on their acceptability to all (reasonable) citizens. According to these views, democracy is to be viewed as a deliberative process of public justification. A consensus reached by citizens after rational, reasoned debate and discussion is required to justify and legitimize political decisions. The deliberative perspective provides an easy argument for democracy: democratic and participatory decision making is needed because the very forming of correct, justified or legitimate decisions require democratic procedures and the participation of large groups of citizens. Democracy just is the procedure by which we can attain justified ethical or political views. (In broad strokes, this is how the deliberative view answers the three main issues of contemporary political philosophy concerning democracy.)

Within this newly conceived debate, pragmatist philosophers began to argue for the relevance of pragmatism - especially John Dewey's views - in political philosophy. Originally a view about the meanings of concepts and propositions proposed by Charles S. Peirce in the 1870s (Peirce 1877/1992; $1878 / 1992$ ), pragmatism quickly started to denote a family of diverse views which emphasized the connection between theory and practice and attempted to elucidate the notion of truth in terms of inquiry and problem-solving. As public intellectuals of their day, two of the key classics of the pragmatist tradition, Peirce and William James had also published various pieces discussing political issues. However, it was Dewey who wrote most extensively on political philosophy, and whose views gradually gained prominence in the contemporary debate. Pragmatist views have been compared with and likened to Rawls's early and later liberalism (of his Political Liberalism, 1996), Habermas' views of discourse ethics as underlying democratic ideals and various other forms of deliberative democracy (e.g. Habermas 1990; Bohman 1998; Misak 2000; Talisse 2007).

Such a likening appears natural. Both contemporary deliberative accounts and pragmatist views are based on structurally similar considerations 


\section{Rydenfelt}

concerning the virtues of democracy. Rather than arguing for democracy based on some first-order value - such as equality or freedom - both views connect democracy with a second-order good which democratic societies, institutions and decision-making are supposed to secure. Pragmatist views tend to connect democracy with the pragmatist account of inquiry: they hold that truth(s) - at least on some issues - can only, or best, be approached within the context of democracy (or at least some set of democratic institutions and procedures). Deliberative views maintain that the validity, legitimacy or correctness of political decisions consists of, or at least depends on, their being the result of a democratic process or procedure; democracy is needful not (only) because of its being or securing something of first-order value, but in the interest of arriving at correct or justified views or valid or legitimate political decisions. However, as I now argue, there are definite and important differences in the two accounts.

\section{Social inqugiry}

A central starting point of (many) pragmatist views of democracy is the pragmatist notion of inquiry, or the process of settling opinion. In the pragmatist account, in its ordinary, everyday version, inquiry begins with doubt, or what Dewey called a problematic situation: some of our beliefs may be called into question, and inquiry is enacted to appease this doubt by attaining a revised or new belief. Scientific inquiry is this process made deliberate; it aims to continuously revise theories and test hypotheses, even those provisionally accepted by the scientific community. A central contention of the pragmatists is that such revision extends to the methods and standards of inquiry itself; our views of justification and criteria for better and worse theories and procedures are themselves the results of these practices and, as such, themselves fallible and always liable to revision. While any inquiry must rest on results already attained and (provisionally) accepted, the methods and theories of science are developed hand in hand, without any a priori guarantees as to their feasibility or correctness.

An important feature of this view of inquiry is that it is not limited to questions of what there is or, perhaps, would be - the sort of questions that we usually think science may address. Rather, it extends to normative questions of what there should be, or what ought to be done (cf. Rydenfelt 2011b; 2015a; 2015b). Critical of any hard dichotomy between descriptive and normative questions, pragmatists - beginning with Peirce - have argued that both kinds of issues can be approached with, broadly speaking, similar means, without reducing normative issues to descriptive or instrumental ones. There is no principled reason, the pragmatists maintain, why values and norms could not become the objects of a practice of deliberate revision, or scientific inquiry.

This extension of scientific inquiry to normative questions Dewey called social inquiry. He found contemporary social science to be stuck between two 
uneasy alternative approaches to the role of values in inquiry. In the first, social or societal issues are addressed in terms of blame and approbation based on preconceived moral views. Social sciences, then, rest on static and fixed, often unstated and implicit, evaluations due to custom or tradition. In the second alternative, in order to refrain from "moralising", evaluations are superficially excluded from science altogether in line with a strong dichotomy between "facts" and "values". Yet this apparent exclusion of evaluations from social science reduces such inquiry "at its very best to the truncated and distorted business of finding out means for realizing objectives already set upon" (Dewey 1938, 490). Neither alternative is satisfactory. Both rely on implicit, unstated goals and evaluations: "the values employed are not determined in and by the process of inquiry" (1938, 496).

In contrast, in Dewey's view, our values and aims (or what Dewey calls our "ends-in-view") should be treated as hypotheses to be tested by and in the process of inquiry. This extends to social and societal policy, which Dewey argues, "is, logically, and should be actually, of the nature of an experiment":

(1) it [a social policy] represents the adoption of one out of a number of alternative conceptions as possible plans of action and (2) its execution is followed by consequences which, while not as capable of definite or exclusive differentiation as in the case of physical experimentation, are none the less observable within limits, so they may serve as tests of the validity of the conception acted upon.

$(1938,502)$

In this view, the test of a value (or an end-in-view) takes place in an experiment, which is the actual adoption of social policy. The policy implemented amounts to the choice of one of a number of alternative courses of action to address a social problem, and its validity can and should be tested by way of its consequences in experience.

However, a concern will inevitably be raised. If our values (or ends-in-view) are tested by their consequences, do we not need another set of values, or ends, in light of which these consequences are assessed? It appears that experimentation with social policy can occur only if there are some further, more final values; this concern is certainly not alleviated by Dewey's occasional talk of values as "means" (cf. Westbrook 1998). Indeed, Dewey maintained that drawing from further values in social inquiry is inevitable; such inquiry "must judge certain objective consequences to be the end which is worth attaining under the given conditions" $(1938,496)$. This dependence on values, however, does not distinguish social inquiry from other lines of inquiry. Physical inquiry, Dewey pointed out, also requires values or ends: all inquiry is a process "of adjudgment, of appraisal or evaluation", as it "demands that out of the complex welter of existential and potentially observable and recordable material, certain material be selected and weighed as data [...]" (1938, 491). Both social and physical inquiry presuppose some view 


\section{Rydenfelt}

of the kind of results of experimentation that speak for or against a hypothesis. Social and physical inquiry are distinguished by their subject matters and, consequently, by the kind of operations and environments in which inquiry takes place. Nevertheless, both types of inquiry assume and require standards of justification (or confirmation or corroboration of a hypothesis by data). What is more, such standards cannot be settled in advance of such inquiry, or by means of philosophical, a priori argumentation. Rather, the standards of justification are themselves explicated, questioned, revised and determined in the process of physical or social inquiry.

Within social inquiry, what could this revision of standards mean in practical terms? The central Deweyan idea here is that the data collected within experimentation with a social policy are not used merely to show how successful the policy was in achieving the ends that it was designed to attain. The same data also speak to the viability of those ends as such: whether the ends were worthwhile in the first place; what other ends were not achieved; whether some further ends were suggested only once the policy was in place; whether the ends that the policy was designed to achieve turned out to be an aspect of some more encompassing end which should be the goal of social policy; and so on. The outcomes of the experiment speak not only to the success of the policy with respect to an initial goal, but more generally to the issue of what kind of data are taken to corroborate or disconfirm the hypothesis - that is, to the general issue of what the goals of social policy should be.

\section{The method of democracy}

Dewey's advocacy of democracy had many motivations, but his view of social inquiry was certainly one among them. In Liberalism and Social Action (1935), he aspired to distinguish the contemporary liberal ideals of democracy from what he called the method of democracy: the extension of "organized cooperative inquiry" into social issues. The background of this discussion lies in Dewey's entrenched criticism of the individualism manifested in classical liberalism and its view of politics largely as a negotiation between the clashing interests of different individuals. In the liberal view, intelligence appears as "an individualistic possession, at best enlarged by public discussion" (1935, 50), "an individual possession to be reached by means of verbal persuasion" $(1935,51)$. A vision of democratic society as comprising groups of individuals represented by political parties or factions is, in Dewey's view, an extension of this liberal view of intelligence into public decision-making. The result is a view of democracy as public discussion, where public "truths" are expected to emerge from the conflict of individual and group interests. Dewey contrasted this procedure of arriving at political "truths" with scientific inquiry:

The idea that the conflict of [political] parties will, by means of public discussion, bring out necessary public truths is a kind of political 
watered-down version of the Hegelian dialectic, with its synthesis arrived at by a union of antithetical conceptions. The method has nothing in common with the procedure of organized cooperative inquiry which has won the triumphs of science in the field of physical nature.

(Dewey 1935, 51)

The notion that discussion suffices for the discovery of physical laws and the structure of reality was replaced, in physical science, by the method of "experimental observation guided by comprehensive working hypothesis, and using all the resources made available by mathematics" $(1935,50)$. In the same vein, Dewey proposed that the notion of democracy as a public discussion should be replaced by the method of democracy - that of organized, cooperative intelligence and experimental inquiry.

Here the contrast between Dewey's method of democracy and deliberative accounts of democracy appears particularly stark. Both Dewey and the proponents of deliberative democracy maintain that democracy should be more than the "majority rule" of ballot boxes; such procedures of representation are often inadequate as means for arriving at increasingly better policies. Yet the deliberative view amounts to advocating just the kind of public discussion which Dewey admonishes for its incomplete and outdated view of ethical and political truths.

This difference between the deliberative perspective and the Deweyan method of democracy points to a divergence in their views of central motivations and aspirations for democracy. The deliberative perspective contributes to an argument for democracy and an account of the role of citizens: a democratic, deliberative process of decision-making is itself justified - or at least needful - because the formation of correct, justified or legitimate decisions requires democratic procedures and the participation of large groups of citizens. Democracy is the procedure by which we can attain justified ethical or political views. In the Deweyan view, in which the method of democracy is funded by the notion of social inquiry, the connection between such inquiry and procedures, organizations, institutions and overall societal settings which deserve to be called democratic appears less straightforward. If simple majority rule and the ideal of reasoned public debate is replaced by the experimental method in the solution of ethical, political and social issues, it is not clear why the resulting practices of social inquiry amount to the method of democracy. ${ }^{1}$ The central issues of the justification of democracy (or the legitimacy of democratic decisions), the procedures and institutions of a functioning democracy and a feasible account of the role of citizens and citizen participation, require a new response.

Many contemporary pragmatist views of democracy have drawn upon the connection between democracy and (social) inquiry in order to address these central issues of contemporary political philosophy. This is a natural move to make. As already pointed out, emphasizing this connection is perhaps the most distinctive contribution of pragmatism to political philosophy. However, 


\section{Rydenfelt}

as the doubts already presented reveal, the connection is also somewhat delicate. Even if the pragmatist view of social inquiry does underwrite an account of democracy, it is far from clear what such a democracy entails. To bring this issue into sharper relief, I now briefly explore the views of contemporary pragmatists.

\section{The pragmatist argument(s) for democracy}

It is doubtful that Dewey - or any of the other classics of pragmatism attempted to formulate an argument that would meet the contemporary challenge of justifying or legitimizing democracy. Dewey's views of social inquiry were only a part of his motivation and conception of democracy. He held that democracy is "more than a form of government; it is primarily a mode of associated living, of conjoint communicated experience" (Dewey 1916, 93). He proposed a commitment to democracy as a way of life that should permeate every form and aspect of human association (e.g. Dewey 1927, 325), and viewed democracy as integral to human flourishing or what he calls "growth". This commitment to democracy has come at a price: Dewey's views in particular have been criticized for creed-like obstinacy (cf. Talisse 2010), while the connection between democracy and growth - as well as the concept of growth more generally - has been found obscure (cf. Hildreth 2011). To remedy this situation, contemporary pragmatists have attempted to formulate arguments that would address present-day concerns with the justification of democracy based on the writings of the classical pragmatists, especially Dewey and Peirce.

Among contemporary pragmatists, it appears that the first to explicitly formulate a pragmatist argument for democracy explicitly is Hilary Putnam (1992; 1994), who claimed to draw it from Dewey. In Putnam's version, the argument has two premises. The first is a pragmatist view of ethical and political truth already explored: ethical and political truths are (or at least may be) discoverable in a process of inquiry (e.g. Putnam 1992, 186). Putnam's second premise is that such inquiry requires democratic standards and ideals in a society. In his view, this latter premise is an empirical claim, which maintains that a "hierarchical" (that is, non-democratic) society "limits the rationality of those at both ends of the hierarchy" (Putnam 1994, 175). Hierarchy "stunts the intellectual growth of the oppressed, and forces the privileged to construct rationalizations to justify their position" (ibid.). Hierarchical societies, Putnam maintains "do not, in these respects, produce solutions to value disputes that are rationally acceptable" (ibid.). Thus, Putnam concludes, we should organize our societies in a democratic fashion, because that is what successful ethical and political inquiry requires; democracy is - at least to the extent that we desire to promote the growth of human intelligence and knowledge - preferable to its alternatives.

Other pragmatists have derived further conclusions based on similar premises. Drawing mainly from Peirce's notion of inquiry, Robert B. Talisse 
(2007; 2010) has attempted to show that (liberal) democracy is a legitimate form of governance in the sense advanced by the tradition of political liberalism: that democracy is acceptable to all reasonable citizens. If we are interested in learning the truth concerning any issue, Talisse maintains, we are already committed to certain conceptions of good evidence, reasons, justification and inquiry; moreover, these conceptions are democratic. This account is indebted to Cheryl Misak's (2000) defence of democracy, which revolves around what she calls the pragmatist methodological principle that "the experience of others must be taken seriously" (Misak 2000, 6). As agents with beliefs, Misak maintains, we are already seeking the truth; truth is, in a familiar dictum, the aim of belief. Seeking truth, in turn, means that we are already committed to a notion of reasons for belief which includes the relevance of the experiences and arguments of various others. If our opinions are to be settled so as to withstand the experience and argument of potentially everyone, the views and experiences of all may be relevant to our inquiries. Everyone thus must have the chance to express their opinion in moral debates; the methodological principle "requires a democracy in inquiry" (Misak 2000, 6).

It is doubtful, however, that such arguments can convince those who do not already share a number of crucial assumptions - for instance, those citizens who maintain non-democratic views (cf. Rydenfelt 2011a; Rydenfelt in press). Putnam's first premise already entails a substantial view of ethical and political issues: that we can, and should attempt to, solve them by way of scientific inquiry rather than, say, by simple reliance on tradition or religious creed. The same ideal of inquiry is also reflected in the second premise. As we saw, in Putnam's view, non-democratic societies curtail the rationality of the citizens at both ends of a hierarchical spectrum, leading to solutions to ethical problems which are not rationally acceptable. This is how things are from the pragmatist point of view: the pragmatist thinks that the methods and aims of inquiry are empirical discoveries, and not based on a priori conceptions of rationality, reasons, evidence and the like. Yet, for the argument to succeed, we must already accept the pragmatist view of how rationally acceptable or justified solutions of value disputes can be achieved - something that not everyone is likely to accept. The problem is all the more urgent when similar premises are used to show that democratic use of state power is legitimate in the sense of being acceptable to all citizens. In Talisse's version, the pragmatist argument is deployed to circumvent the problem of founding democracy on substantial ethical and political views that may be rejectable by some citizens. However, even if this view of democracy is not centred on some comprehensive ethical view, to accept it we must still share a number of assumptions concerning rationality, truth and the requirements of good inquiry - in other words, a comprehensive epistemic view (cf. Rydenfelt 2011a; 2013).

Concentrating on the original issue of the connection between democracy and the pragmatist view of inquiry, we might grant the first premise as well as 


\section{Rydenfelt}

its consequences for the empirical revisability of the standards of rationality or justification. Perhaps the arguments at hand do not convince those who do not share the pragmatist view of inquiry into ethical and political issues; nevertheless, this is what the distinctively pragmatist view of democracy maintains. Even then, however, the second premise of Putnam's argument faces a challenge. Putnam maintains that this premise is empirical. Is it really obvious that experiences of inquiry - either in general, or into ethical issues in particular - have led us to think that inquiry can only (or even best) be pursued in a democratic setting? Putnam himself admits that sometimes full "democratization" is not a prerequisite of scientific inquiry: such inquiry may be conducted, for example, when a tyrant allows limited freedom of speech among a group of physicists engaged in specific research (1994, 175). Yet one might argue that this is the case of inquiry more generally. While it seems clear that the advancement of science does depend on the availability of information - at least of previous studies and empirical data - high quality science has been performed in contexts which are by no means democratic. Perhaps good science involves some elements of democratic governance, but it seems hardly evident that its progress presupposes a democratic societal setting. Why should things be any different in the case of inquiry into ethical and political issues?

\section{The role of citizens}

The question arrived at concerns the role of citizens. Again, consider the contrast between the pragmatist view and deliberative democracy. In the latter view, citizens must be involved and included in public deliberation; the test of the correctness, validity or legitimacy of political decisions is that a consensus is reached among them. In the pragmatist view, deliberation and consensus has no such role; rather - at least in contemporary accounts - it is argued that inquiry into ethical, political and societal issues demands "democracy". But how? What is the role of "ordinary" citizens in such inquiry?

The answer that many contemporary pragmatists have supplied is that the knowledge, particular perspective and experiences of any citizen may contribute to the advancement of inquiry. Drawing mainly from Peirce but also from Dewey, Cheryl Misak, as we saw, has pointed out that the experiences of everyone may be relevant to ethical and political inquiry. Similarly, Elizabeth Anderson (2006) has argued that Dewey's experimentalist view of inquiry entails the inclusion of citizens of diverse backgrounds, opinions and the like. In Anderson's view, the exclusion of some citizens would hinder the "ability of collective decision-making to take advantage of citizens' situated knowledge the fact that citizens from different walks of life have different experiences of problems and policies of public interest, experiences that have evidential import for devising and evaluating solutions"; in contrast, "[u]niversal inclusion makes maximal use of such situated knowledge" (Anderson 2006, 34). 
James Bohman, in turn, has argued that the "epistemic benefits of democracy", in Dewey's view, "derive from a practice of deliberation in which many different perspectives are brought to bear in an ongoing process of formulation, testing, and revision" (Bohman 2010, 53). ${ }^{2}$

While the idea of the potential benefits of drawing from the knowledge accrued by large numbers of people (or citizens) is part of the connection which Dewey made between democracy and social inquiry, as defences of the relevance of the views of "ordinary" citizens these accounts suffer from serious problems. It is unclear - at least unless much more is said of the contribution that citizens are expected to make - why the same information and knowledge would not be possessed, or at least very easily acquired, by experts. Indeed, these views of the role of citizens risk reducing the intelligence operative in inquiry to the potential contribution of individual intellects - that is, to the compound of individual knowledge - rather than viewing that intelligence as encompassing the whole process of testing social policy. That is, these views threaten to obfuscate the experimental nature of social inquiry. For example, although Bohman lists different stages of the scrutiny of a hypothesis - formulation, testing and revision - it appears that the (democratic) process of inquiry is still understood as the collection of information in a conversation between different "perspectives" and the interests they include in a process of deliberation. Such collection of information is needful to identify the issues and problems at hand and to formulate initial ideas for solutions. As Dewey had it, "fact-finding procedures are necessary for (1) determination of problems and for (2) provision of data that indicate and test hypotheses" $(1938,500)$. However, the ultimate test of a social policy is in its observable consequences when put into action by means of experiment.

Indeed, rather than the relevance of individual contribution to knowledge, it is the experimental nature of social inquiry that ultimately makes the engagement of "ordinary" citizens needful. Unlike in physical science advanced in the laboratory or observatory, the experiments of social inquiry must be actionable in the actual association of actual people. Dewey went so far as to say that this must a part of the very process of devising a hypothesis: "Any hypothesis as to a social end must include as part of itself the idea of organized association among those who are to execute the operations it formulates and directs" (1938, 496). Moreover, attributing some bearing and significance to the consequences of an experiment requires that those consequences take place in human practice. The relevance and significance of those consequences cannot be determined, Dewey maintained, except by "active or 'practical' operations conducted according to an idea which is a plan" $(1938,504)$. Social inquiry, then, would be impossible - at least in our current conditions - without citizens both willing to engage in its practical operations and organized, in groups and as a society, in a fashion that makes experimentation with social policy possible. ${ }^{3}$ Social inquiry cannot begin unless the required societal organization and the willingness to participate are in place. 
What would this process of experimentation look like in practice? The starting point of social inquiry is a problematic situation. Such inquiry must begin with an attempt to identify societal problems, formulate them in an accessible manner and devise hypotheses concerning possible solutions. This part of the process is close to deliberation, wherein "ordinary" citizens can participate and present their views of the problems they are facing, identify shared problems and propose different ideas for possible solutions. However, this is just one stage of social inquiry. After the problem has been identified and hypotheses concerning its solution have been devised, the hypothesis - a social policy - is then introduced to human practices. The role of citizens, at this stage, is to engage in their everyday social practices affected by the new policy. The outcomes generated are then assessed; for the collection of such data, the input of citizens and their views of the outcomes and their relevance are needful. The method of democracy involves not only discussion and deliberation to identify problems and possible solutions, nor only an assessment of results, but includes both as stages of the experimentation of policy within human practices. Although the process itself can be expert-driven, citizens' participation is required for the success of the overall process of inquiry: without their contribution at each stage, the inquiry could not be conducted.

Accordingly, we can make some sense of Dewey's proposal that democracy should permeate every form of human association. This was not to imply that we should decide everything by majority rule. The pragmatist view of democracy is a relatively radical one; it is not wedded to many of the features of contemporary Western societies with which we have grown accustomed to identify democracy: certain institutions, representational forms of government, voting, elections and so on. A successful implementation of the pragmatist vision doubtless requires that some (aspects of) these institutions are in place. Social inquiry would likely be stymied by an absence of free speech or the kind of educational institutions which produce experts able to engage in social inquiry, as well as citizens willing to engage in that process. However, the traditional institutions of Western democracy may themselves be subject to gradual revision in the search for better ways in which to devise and revise social and societal policy.

\section{Conclusion}

The pragmatist perspective on democracy is distinct from élitist and deliberative views of democracy. Rather than citizen representation and voting or participating in public deliberation, the starting point of the pragmatist perspective is a view of social inquiry into normative issues as a form of experimental science. This "method" of democracy, however, requires an articulation of the role of (ordinary) citizens: why is this inquiry not best conducted by merely by experts? I have proposed that social inquiry involves citizens participating in the improvement of social policy in terms of their 
everyday practices. It is this understanding of the connection between social inquiry and actual, everyday social practices that gives content to the pragmatist insistence that inquiry requires "democracy". Ordinary citizens' engagement in various stages of the experimental process is needful for its success. Accordingly, if there is a pragmatist "justification" of democracy, it is this: social inquiry requires more than experts. Fashioning democracy through the lens of social inquiry means, however, that the pragmatists - like Dewey - are unlikely to provide a detailed account of any fixed institutional and constitutional requirements of democracy. In line with the processes of any experimental line of inquiry, the specific methods of social inquiry are always subject to revision.

\section{Notes}

1 This is not to say that the deliberative view is without its problems; indeed, it is vulnerable to a relatively simple counterargument. Although deliberative democracy is not founded on the (alleged) acceptance of some particular (first-order) value, it nevertheless rests on a substantial conception of the correctness, justification or legitimacy of ethical and political views as a product of a free, rational, consensus-yielding discussion (cf. Rydenfelt 2013). This conception can be rejected by some citizens, rendering the justification of democracy suspect at least from some points of view. The same is the case with the more particular ideals and practices that theorists have suggested are integral to the deliberative process, such as the tolerance of pluralism of opinion and equality in making and criticizing proposals for policy (cf. Cohen 1989).

2 This is where pragmatism also promises to bridge the gap between the consensusoriented, liberal view and the agonist version of democracy that opposes it. The high bar of legitimacy set by the demand of acceptability to all citizens has been extended to act as the basis of foundational democratic principles (Rawls), and a rational consensus has been advanced as a criterion for the correctness of moral and political views (Habermas, many deliberative theorists). According to critics such as Chantal Mouffe (2013), such a view risks downplaying the conflict of views that occurs in a democratic societal setting. By analogy with scientific inquiry, the pragmatist can argue that democracy requires both moments of consensus and conflict; while relative uniformity of opinion about some central aims and values is needful to provide the starting points of such inquiry, diversity and pluralism of opinion provides the impetus necessary for constant revision of even well entrenched views.

3 It should be noted that technological development - especially advances in simulation and virtual reality - may eventually reduce the need to test social policies in actual human practices. However, while computer simulations, for example, can be deployed to test social policies against their desired ends-in-view, it is not at all clear whether simulations can ultimately provide data sufficient for the testing of those ends themselves.

\section{References}

Anderson, E. (2006). The epistemology of democracy. Episteme, 3(1-2), 8-22.

Bohman, J. (1998). Survey article: The coming of age of deliberative democracy. The Journal of Political Philosophy, 6(4), 400-425. 


\section{Rydenfelt}

Bohman, J. (2010). Participation through publics: Did Dewey answer Lippmann? Contemporary Pragmatism, 7(1), 49-68.

Cohen, J. (1989). Deliberation and democratic legitimacy. In A. Hamlin \& P. Pettit (Eds.). The good polity: Normative analysis of the state (pp. 17-34). New York: Blackwell.

Dewey, J. (1916). Democracy and education. In J.A. Boydston (Ed.). The middle works of John Dewey (Volume 9, pp. 1-370). Carbondale: Southern Illinois University Press.

Dewey, J. (1927). The public and its problems. In J.A. Boydston (Ed.). The later works of John Dewey (Volume 2, pp. 235-372). Carbondale: Southern Illinois University Press.

Dewey, J. (1935). Liberalism and social action. In J.A. Boydston (Ed.). The later works of John Dewey (Volume 11, pp. 1-66). Carbondale: Southern Illinois University Press.

Dewey, J. (1938). Logic: The theory of inquiry. In J.A. Boydston (Ed.). The later works of John Dewey (Volume 12, pp. 1-528). Carbondale: Southern Illinois University Press.

Habermas, J. (1990). Moral consciousness and communicative action (C. Lenhardt \& S. W. Nicholsen, Trans.). Cambridge: Polity Press.

Held, D. (1987). Models of democracy. Stanford, CA: Stanford University Press.

Hildreth, R.W. (2011). What good is growth? Reconsidering Dewey on the ends of education. Education \& Culture, 27(2), 28-47.

Locke, J. (1988). Two treatises of government (Peter Laslett, Ed.). Cambridge: Cambridge University Press. (Original work published 1689).

Misak, C. (2000). Truth, politics, morality: Pragmatism and deliberation. London: Routledge.

Mouffe, C. (2013). Agonistics: Thinking the world politically. London \& New York: Verso.

Peirce, C.S. (1992). The fixation of belief. In N. Houser \& C. Kloesel (Eds.). The essential Peirce (Volume 1, pp. 109-123). Bloomington: Indiana University Press. (Original work published 1877).

Peirce, C.S. (1992). How to make our ideas clear. In N. Houser \& C. Kloesel (Eds.). The essential Peirce (Volume 1, pp. 124-141). Bloomington: Indiana University Press. (Original work published 1878).

Putnam, H. (1992). Renewing philosophy. Cambridge, MA: Harvard University Press.

Putnam, H. (1994). Pragmatism and moral objectivity. In J. Conant (Ed.). Words and life (pp. 151-182). Cambridge, MA: Harvard University Press.

Rawls, J. (1996). Political liberalism. New York: Columbia University Press.

Rawls, J. (1999). A theory of justice (Revised edition). Cambridge, MA: Belknap Press. (Original work published 1971).

Rydenfelt, H. (2011a). Naturalism and normative science. In J. Knowles \& H. Rydenfelt (Eds.). Pragmatism, science and naturalism (pp. 15-38). Berlin and New York: Peter Lang.

Rydenfelt, H. (2011b). Epistemic norms and democracy. Metaphilosophy, 42(5), 572-588.

Rydenfelt, H. (2013). Constructivist problems, realist solutions. In J. Kegley \& K. Skowronski (Eds.). Persuasion and compulsion in democracy (pp. 153-169). Lanham, MD: Lexington Books.

Rydenfelt, H. (2015a). Pragmatism, objectivity and normative science. In U. Zackariasson (Ed.). Action, belief and inquiry: Pragmatist perspectives on science, society and religion (pp. 69-93). Helsinki: Nordic Pragmatism Network. 
Rydenfelt, H. (2015b). Emotional interpretants and ethical inquiry. Sign System Studies, 43(4), 501-513.

Rydenfelt, H. (in press). Democracy and moral inquiry: Problems of the methodological argument. Transactions of the Charles S. Peirce Society.

Schumpeter, J. (1950). Capitalism, socialism, and democracy (3rd ed.). New York: Harper \& Row.

Talisse, R.B. (2007). A pragmatist philosophy of democracy. London: Routledge.

Talisse, R.B. (2010). Peirce and pragmatist democratic theory. In M. Bergman, S. Paavola, A. Pietarinen \& H. Rydenfelt (Eds.). Ideas in action: Proceedings of the applying Peirce conference (pp. 105-116). Helsinki: Nordic Pragmatism Network.

Walzer, M. (1983). Spheres of justice. New York: Basic Books.

Westbrook, R.B. (1998). Pragmatism and democracy: Reconstructing the logic of John Dewey's faith. In M. Dickstein (Ed.). The revival of pragmatism: New essays on social thought, law, and culture (pp. 128-140). Durham, NC: Duke University Press.

Whipple, M. (2005). The Dewey-Lippmann debate today: Communication distortions, reflective agency, and participatory democracy. Sociological Theory, 23(2), 156-178. 


\title{
4 John Dewey's notion of social intelligence
}

\author{
Veli-Mikko Kauppi, Katariina Holma and \\ Tiina Kontinen
}

\section{Introduction}

This chapter focuses on a Deweyan understanding of intelligence as fundamentally social. This differs from conceptions of intelligence as a feature of an isolated individual or as the possession of an elite, which derive from longstanding philosophical traditions and are prevalent even today. Concrete illustrations of the effects of these traditional conceptions of intelligence can be seen in fields of study related to this project. For example, the study of the practices of citizenship and the work of nongovernmental organizations (NGOs) to strengthen citizenship often raise problems that could be understood from the perspective of the contextuality of intelligence. Solutions concerning deliberative participation or citizens' engagement developed in one societal and political context are often presented as universal guidelines for intelligent action, suitable for other settings, without in-depth understanding of their context (see Banks et al. 2015, 708-711; Pettit 2016, 89).

As Gaventa $(2004,34)$ notes, this may result in a situation where a solution that in one context was considered intelligent and liberating, becomes an instrument for "reinforcing domination and control" in another. For example, in terms of learning citizenship skills, many educational interventions in the development sphere are based on modern theories of education and learning, which have been accused of one-sidedly stressing developing the skills, knowledge, capacities and attitudes of the individual (see Triandis 1995; Peters \& Marshall 1996). The idea of social intelligence, on the other hand, resonates with the priority of a "social individual", an individual essentially embedded in the community, the model commonly seen as prevalent in subSaharan contexts (Kaphagawani 1998). Therefore, we contend that Dewey's theory of social intelligence provides a useful conceptualization that can facilitate our understanding of the social learning of citizenship.

Dewey bases his theory of intelligence ${ }^{1}$ on an evolutionary understanding of human nature and development, constructing it in light of the social nature of action. His goal of re-theorizing intelligence is closely related to one of the main efforts of pragmatism; at the turn of the nineteenth century, an era of 
rapid and thorough changes in industrializing societies, pragmatism aimed at revising earlier philosophy in the light of what were novel findings in both the natural and the social sciences. By focusing on evolutionary theory on the one hand and practice on the other, his theory sought to mediate between opposing views, challenging both the mind-body dualism and the division between the individual and the social (Scheffler 1974; Biesta \& Burbules 2003).

Dewey argues that theories of intelligence as an individual possession are misleading and may prevent us from making the most of human intelligence. He also provides insights into how we should develop human collaboration based on his theory of social intelligence. Pointing to some earlier theories which have, in his view, misinterpreted this notion, he points out that philosophical liberalism's ${ }^{2}$ conception of the individual is isolated and atomistic. This misconception, he argues, dims the connections of an individual with everything that surrounds and creates her as she pursues understanding of the world and attempts to reform it through "initiative, inventiveness and intelligently directed labor" (Dewey 1919, 107-108). At the level of society this has led to seeing social action as a field of singular wants, wills, feelings and sensations formed in their own bubbles, mostly driven by a passion for financial profit or other gains (Dewey 1927, 249; 1930, 78). A second line of critique for Dewey is what can be termed an elitist conception of intelligence, which, in his view, originates from the Western history of Enlightenment, Christian philosophy and the philosophy of ancient Greece. In this view, he argues, intelligence is seen as the possession of highly educated people, and as separate from solving everyday problems (Dewey 1916, 269-275; 1917, 38).

In the following, we begin by providing an overview of Dewey's theory of intelligence as a social phenomenon, focusing on how, according to this understanding, it forms, manifests and cumulates in interactions. We point out the connection between the notion of intelligence and action, problem solving, and learning as a reformulation of habits. We then discuss some presumed implications of Dewey's theory in terms of the contextuality of intelligent action, the importance of taking relevant, experience-based information into account, the use of a particular method of inquiry and modification of educational settings. In conclusion, we contend that the Deweyan notion of social intelligence provides an additional conceptual angle to address some of the challenges related to understanding contextualized citizenship and its learning.

\section{Social intelligence in Dewey's philosophy}

Dewey presents intelligence as something which forms and manifests in interaction. This notion is based on his critique of the model that presents the individual and the social as antithetical or as opposing forces (Dewey 1918, $57 ; 1919,194 ; 1927,351)$, arguing that this view leads to the false conclusion that effective intelligence is an individual possession (Dewey 1927, 367; 1935, 38). An individual human, in Western tradition, is seen as the building block 
of society, someone who makes independent decisions and choices. However, Dewey maintains that it is impossible to identify anything completely individual, discrete and apart from the endless network of interactions with everything that surrounds it. This understanding does not reject the meaning of the parts - that is, individuals - but makes it rather useless to focus on them on their own. No change of scale or spectrum will alter the fact that things are what they are in relation to their surroundings (Dewey 1927, 351-352). The artificial isolation of an individual from the environment is not beneficial for the understanding of either.

In response, Dewey presents the individual and the social as inseparable. He conceptualizes intelligence as a fundamentally social phenomenon, gained through individual experience in social relationships, practices and interdependencies, having value and operating within this social frame. He also points out that the human environment is formed both by material surroundings and, of especial importance, by interconnected human actions: a cultural matrix that is the medium in which each individual grows, lives and acts (Dewey 1916, 282-283, 304; 1938a, 481). Only in association with others does one become a conscious centre of experience (Dewey 1919, 198). The environment in which the individual experiences interaction with others thereby socially forming habits and adopting morals - is the source of the individual's formation (Dewey 1938b, 22). Dewey goes to extremes by stating, "Conceive mind as anything but one factor partaking along with others in the production of consequences, and it becomes meaningless" (Dewey 1916, 139).

Thus Dewey provides a particular understanding of the notion of experience and its relation to intelligence. He sees individual experience and the surrounding world as inseparable, and intelligence as an organizing factor within experience (Dewey 1919, 132). In the course of any experience, according to him, an individual changes and develops due to interaction with the world (Dewey 1934, 251). Furthermore, this interaction is never a onesided and passive observation of objects, as even a newborn child experiences the objects of the external world through their meaning, as well as the effects that these objects - and actions taken in relation to them - may have (Dewey 1916, 279-280; 1934, 251). To treat experience as something that happens in a vacuum inside an individual misses the fact that experience is constantly fed from springs outside the individual (Dewey 1938b, 22).

All kinds of association with others has an effect on the mentality and character of an individual (Dewey 1930, 80-81), leaving the stamp of a community (Dewey 1922 , 218) via a web of concepts and categories "within which and by which individual thinking, however daring and original, is compelled to move" (Dewey 1938a, 482, quoting Concord's From Religion to Philosophy). Individuals have the power to react, respond to and change their environment, including "the intelligence, the knowledge, ideas and purposes that have been integrated in the medium in which individuals live" (Dewey 1935, 48-49). By joining this social interaction, by sharing in activities that manifest common beliefs, judgment and knowing, a person "gradually acquires a mind of his own" (Dewey 1916, 304; 1922, 130). 
The stuff of belief and proposition is not originated by us. It comes to us from others, by education, tradition and the suggestion of the environment. Our intelligence is bound up, so far as its materials are concerned, with the community life of which we are a part. We know what it communicates to us, and know according to the habits it forms in us.

(Dewey 1922, 217)

This makes intelligence in many ways cumulative, and stresses the importance of cooperation in intelligent action. From the Deweyan point of view, participation and cooperation are something in which humans are born as they gradually develop in the network of social ties and relationships that bring with them the history, past achievements and restrictions of societies. Individuals may join the intelligent social action at hand, and also engage with the previous achievements of others, taking those achievements further, in a way that would not be possible for any individual alone. Individuals' minds and actions are dependent on the cumulated shared heredity transmitted through education, instruction and communication (Dewey 1899, 69; $1927,300,366)$. The individual adopts as her own some phase of the cumulatively built intelligence of a multitude of cooperating individuals (Dewey 1935, 48-49). With the aid of her surrounding world and its proceedings, an individual can easily overcome problems that decades ago were impossible for undoubtedly genius minds to solve. Vice versa, she would indeed fail sooner than later, if she were to try and solve problems that to most of us seem mundane, if she were to try on her own in isolation, no matter what a mastermind she is.

Henry George ${ }^{3}$, speaking of ships that ply the ocean with a velocity of five or six hundred miles a day, remarked, "There is nothing whatever to show that the men who to-day build and navigate and use such ships are one whit superior in any physical or mental quality to their ancestors, whose best vessel was a coracle of wicker and hide. The enormous improvement which these ships show is not an improvement of human nature; it is an improvement of society - it is due to a wider and fuller union of individual efforts in accomplishment of common ends." This single instance, duly pondered, gives a better idea of the nature of intelligence and its social office than would a volume of abstract dissertation.

(Dewey 1935, 48)

In the pragmatist framework, intelligence is, in the final analysis, understood in terms of the possibility of action that it may provide (Dewey 1916, 353-354; 1935, 34-35; see also Peirce 1878, 293), meaning that the concept of habit (see further in Holma \& Kontinen, this volume) is crucial for understanding the relationship between intelligence and action. Individual and collective habits - the mainspring of human action according to Dewey - are tested ways of possible action, ways of responding to the world and the 
problems it poses, by "selecting material from the store of knowledge amassed in past experience" (Dewey 1922, 51; 1935, 37). Habits, too, are socially passed on and learned in interaction, and they may change if they cease to act as solutions to the problems faced.

Thus, one of the crucial roles of intelligence is to modify old habits in order to provide possibilities for action that meets the new conditions (Dewey 1935, 37). The process of clarifying a new problem to be solved is set in motion by moments of disruption, both between the individual and her surroundings (Dewey 1922, 91; 1934, 20-23), and between the internal and external relations of society (Dewey 1935, 58). Indeed, change and disruption are fundamental to the process of learning, as they challenge old habits of thought and action. Dewey suggests that education, being a means for both continuity and reformation in society, should be reconsidered, starting with a scientific understanding of human nature and mind as operating through experience and the formation of habits (ibid., 34-35). Nevertheless, one-sidedly aiming changing habits through education would be useless, unless the environment and problems to which those habits respond to are also worked on and changed (Dewey 1922, 19-20; 1935, 44-45).

To conclude, if we compare the Deweyan view of intelligence, which sees it as a function of association and communication (Dewey 1927, 334), with the view which sees intelligence as an individual possession, it seems that the former provides us with a different, yet very reasonable conceptual framework for analyzing and developing human communities and societies. In the next section, we reflect the main implications of Dewey's theory of intelligence.

\section{Reflections on the implications of Dewey's theory}

Dewey suggests that if we create conditions for intelligence to flourish, we also create a better functioning society, one that gains from the growth of individuals and their capability to engage with intelligent action. In what follows, we reflect on four potential implications of Dewey's theory, which are, in many ways, connected to what Dewey calls social inquiry: a method that incorporates members of a society into its intelligent and experimental reformation (see further Rydenfelt, this volume).

The first reflection concerns the contextuality of all theorization. This is to say that we must refute the idea that philosophy can offer universal, wholesale solutions, and we should take seriously the inevitable contextuality of intelligent action. Dewey accuses philosophers of often treating social issues in a way that seeks to present general and universal answers to specific and detailed problems. By doing this, he claims, philosophy closes inquiries, rather than conducts them (Dewey 1919, 188). Dewey argues that the quest for universal answers actually hampers the ability to solve problems, because an attempt to solve a problem whose conditions have not been clearly determined is "simply useless" (Dewey 1938a, 488). He underlines the absurdity of this effort by presenting the analogy of trying to build a universal railroad in 
general, regardless of geography, human populations and needs, and so on (Dewey 2015). The trouble with wholesale solutions is not only the consequent lack of details; equally troublesome is the fact that general answers that have worked at one point of history often become irrelevant due to the temporality of problems. In other words, wholesale solutions make the takenfor-granted assumption that a solution that once worked in a certain setting should be, as a rule, applied to completely different settings as well, without inquiry into current conditions. When we understand that the world is in constant change, we recognize the need to analyze whether solutions once tested and proven suitable - including our own habits - still work with the new problems that arise in new situations. As "intelligence develops within the sphere of action for the sake of possibilities not yet given" (Dewey 1917, 45), it could be alleged that wholesale solutions fail not only in determining the sphere of action, but also in opening new possibilities beyond our present imagination in any particular context.

The second reflection relates to the connection between the notion of intelligence and experience-based knowledge. Dewey is suspicious of an elitist conception of intelligence, stating that "the combined observations of a number cover more ground than those of a single person" (Dewey 1927, 268). There, Dewey takes a critical look at the scope of philosophy of the time, ${ }^{4}$ which he accuses of favouring its own class interests rather than contributing to the general goal of asking and solving questions that truly matter in people's lives. In his book, The Public and Its Problems, he is against promoting the formation of an expert elite, as "[a] class of experts is inevitably so removed from common interests as to become a class with private interests and private knowledge, which in social matters is not knowledge at all" (ibid, 364). This would strongly counter his insistence on social inquiries that are specific and detailed. In contrast to holding onto elitist, private knowledge, he argues that, to solve social problems in the best possible way, we must have the best possible knowledge of them, their causes, effects and so forth. In the elitist view, such knowledge lies with well-read intellectuals and experts in specific areas. However, a full understanding of problem, according to Dewey, requires highly experience-based knowledge, since everyone has extensive intelligence regarding his or her own life situation. The danger of the failure to see the intelligent potential embedded in everyday lives and common habits, consequently rejecting some pieces of the puzzle, is that we cannot get a sufficiently clear picture of our total reality. To attain this, we must be able to gather a wide range of interpretations of reality from the individuals that constitute and reform the social. To make all human potential flourish we must be interested in knowledge from actual lived experiences and make use of it, not reject it as seemingly unintelligent.

Knowledge produced by lived experience is also the source of remedies for problems, promoting change towards a better situation. As Dewey states, "The man who wears the shoe knows best that it pinches and where it pinches, even if the expert shoemaker is the best judge of how the trouble is to be 
remedied" (Dewey 1927, 364). Although individual thinking flows through socially formed channels, it is also a potential source of new ideas, of intellectual variation in observation, imagination, judgment and invention, sometimes differing from current belief and, thus, suggesting change and progress and putting it in motion (Dewey 1916, 304-306). In the course of problem solving, these variations should be nourished, given the opportunity to spread and to reach those in charge of conducting changes as specialists in their own social fields (Dewey 1927, 365): to inform those whose responsibility it is to fix the shoe, to continue with the analogy.

Therefore, Dewey's view of social intelligence does not exclude specific expertise, gained, for instance, from education. His view implies, however, that to solve contextualized problems, such expert knowledge alone does not suffice; rather, it requires experience-based knowledge from everyone. At best, participants with different experiences can form a community of inquiry in which social intelligence grows through collaborative experimentation.

Our third reflection is thus related to Dewey's "method of social inquiry" and its use of experience-based knowledge. In Dewey's view, in order to direct social affairs so as to produce a better society, we must follow the principles of scientific experimentation and inquiry, which, inspired by the spirit of his time, he regards as distinctive dimensions of material and technological progress in human history (Dewey 1927, 238; 1935, 51, 64). He stresses that the scientific method is a self-regulating mode of intelligence, suggesting that the same kind of idea should also be a precondition in social inquiry. Then, inquiry and experimentation can be conducted through controlled provision of knowledge by all inquirers, without relying merely on "the happy intuitions of individual minds" (Dewey 1935, 34). In Dewey's view, the social sciences have long ignored the development of this kind of method, leading to a situation in which social policies promoting changes in society are often randomly formed on the basis of generalizations that obscure information and knowledge of the specific situation. Of course, Dewey's view of the possibilities of this kind of method in solving societal problems can be seen as overly optimistic from the contemporary perspective (Holma \& Kontinen 2015, 29 30); however, some dimensions of his idea of shared inquiry which takes experience-based knowledge seriously are relevant, even if we take a critical position on the wider idea.

The fourth reflection concerns the educational implication of Dewey's idea of social inquiry. For instance, Dewey had the view that the habit of scientific inquiry - which he suggested be extended to social matters - should be learned at school, in every branch of study, in a way that would enable connecting thought with the possibility of action, and action with context: that is, the "habits and ideas from which it sprang" (Dewey 1935, 34-35). This kind of education would better reveal the surrounding relations of the world, providing learners with the power of re-adaptation in changing conditions, thus making them less easily objects of someone else's ends (Dewey 1916, 328329). This idea resonates, for example, with the principles of critical 
education: becoming conscious of conditions and achieving the ability to act upon them (cf. Freire 1970/2005, 176; Shor \& Freire 1987, 45-46; see also Bananuka \& John, this volume).

Dewey also argues that educational systems often mislay a lot of intelligent potential. On the one hand, many without access to formal schooling are nevertheless highly intelligent, especially when it comes to understanding and changing their own life conditions. Moreover, Dewey suggests that this lack of formal schooling can even be a positive factor, as it facilitates the ability to learn from experience, rather than losing the appetite for learning in a school that might have taught things not meaningful to the student's context (Dewey 1938b, 29). This underlines the fact that there is a lot of intelligent action produced outside formal education, and a successful educational system must be able to acknowledge these sources in order to include them and the potentially precious knowledge provided by them. This acknowledgement augments the pursuit of shared intelligent action. In contrast, if an educational system imagines that it already has the solution to every problem without engaging in further inquiry, and that it only needs to deliver these solutions to its recipients, it is bound to go astray.

Considering the point of view of an individual not allowed to train or participate in intelligent social action, this of course appears a waste of potential and capacities, and thus a personal loss. Throughout his work, Dewey was convinced that we cannot assign intelligence and education to a small elite. Instead, everyone must have access to intelligence and a chance to participate intelligently (Dewey 1898, 383; 1899, 5; 1916, 269-270). Looking at society, on the other hand, an enormous potential is lost if its educational systems fail to acknowledge and make use of some of the intelligence that is manifest in the habits and actions of its members. Equally, society is harmed if it takes the intelligence provided by established sources in a taken-forgranted way and without critical appraisal.

\section{Conclusions}

In conclusion, we contend that the Deweyan notion of social intelligence provides an additional conceptual angle from which to address some of the challenges related to understanding contextual citizenship and its learning. Dewey's theory offers a powerful challenge to the idea of independent and isolated human beings in individual possession of different degrees of intelligence, who, based on this intelligence, make deliberate choices as members of human communities. Indeed, it inspires a shift in analytical starting point from isolated individuals to social practices where intelligence is produced; this resonates with understandings of citizenship in Africa as something not primarily exercised in accordance with the idea of a liberal individual, but within "intermediate solidarities" (Englund 2004). In the light of Dewey's idea of associated behaviour that "brings customs and institutions into being" (Dewey 1927, 301), we should focus on intelligence, not as the property of an 


\section{Kauppi, Holma and Kontinen}

individual, but as related both to the structure of the social context and its institutions, and to habits of association, communication and the solving of shared problems: elements that may both hinder and foster the full flourishing of social intelligence.

These points are all worth considering when conducting empirical studies, but also when planning or implementing action that aims at strengthening societies and communities. The four reflections presented in the previous section may be helpful in building research settings and developing best practices: focusing on real-life contexts, making use of experience-based knowledge, using the method of social inquiry and revising our educational operations.

In the particular context of this book and its concern with educational interventions to strengthen citizenship in sub-Saharan Africa, these reflections would imply: 1) embarking from the contextual experience of local people; 2) acknowledging the knowledge of those without formal education but, nevertheless, in possession of extensive experience of everyday problem-solving; 3) initiating social inquiry into problems people consider relevant to their situations; and 4) appreciating everyone's participation in educational initiatives. In so doing, the social intelligence formed, at its best, can provide new possibilities for action. Although Dewey's notions are based on an unconditional belief in the possibilities of a model of scientific inquiry to bring about progress - something that contradicts our contemporary knowledge of global challenges - they nevertheless provide fresh ideas to be developed further in our investigation and promotion of learning that leads to a more engaged citizenship.

\section{Notes}

1 It is important to note that the Deweyan approach to intelligence is different both from the idea of intelligence which is the basis for psychological IQ tests and from everyday ideas of intelligence such as the image of a classic "intellectual" that we may picture when we discuss the subject. Although these conceptions may be useful in certain settings, they often fail to address the social aspect of intelligence as well as lacking understanding of the connections between intelligence and social action. Additionally, when Dewey uses the term social intelligence, he does not refer to the more recent use of the term, especially in popular psychology (cf. Goleman 2006), which mainly refers to a person's knowledge and capacities in social situations.

2 Although sharing a common heritage, liberalism as a diverse political and moral philosophy is not to be confused here with economic liberalism. Dewey himself subscribes to the core tenet of liberalism: the idea of liberating people from old oppressive power structures and modes of thinking (Dewey 1935, 40), but argues that liberalism involves a false conception of intelligence as a separate possession formed apart from the social world.

3 Henry George (1839-1897) was an American journalist and political economist, and the father of a political philosophy called Georgism.

4 It should be noted that as Dewey talks of philosophy here, we should presumably consider including at least social psychology and sociology in this critique, as they were emerging partly under philosophy's sphere during the time of Dewey's criticism. 


\section{References}

Bananuka, T.H. \& John, V.M. (2019). The crafting of "critical education": Experiences of a Ugandan NGO. In this volume.

Banks, N., Hulme, D. \& Edwards, M. (2015). NGOs, states, and donors revisited: Still too close for comfort? World Development, 66, 707-718.

Biesta, G.J.J. \& Burbules, N.C. (2003). Pragmatism and educational research. Philosophy, theory and educational research series. Lanham: Rowman \& Littlefield Publishers, Inc.

Dewey, J. (1898). Review of psychologic foundations of education by William Torrey Harris. In J.A. Boydston (Ed.). The early works of John Dewey (Volume 5, pp. 372384). Carbondale: Southern Illinois University Press.

Dewey, J. (1899). The school and society. In J.A. Boydston (Ed.). The middle works of John Dewey (Volume 1, pp. 1-111). Carbondale: Southern Illinois University Press.

Dewey, J. (1916). Democracy and education. In J.A. Boydston (Ed.). The middle works of John Dewey (Volume 9, pp. 1-370). Carbondale: Southern Illinois University Press.

Dewey, J. (1917). The need for a recovery of philosophy. In J.A. Boydston (Ed.). The middle works of John Dewey (Volume 10, pp. 3-48). Carbondale: Southern Illinois University Press.

Dewey, J. (1918). Education and social direction. In J.A. Boydston (Ed.). The middle works of John Dewey (Volume 11, pp. 54-57). Carbondale: Southern Illinois University Press.

Dewey, J. (1919). Reconstruction in philosophy. In J.A. Boydston (Ed.). The middle works of John Dewey (Volume 12, pp. 77-202). Carbondale: Southern Illinois University Press.

Dewey, J. (1922). Human nature and conduct: An introduction to social psychology. In J.A. Boydston (Ed.). The middle works of John Dewey (Volume 14, pp. 1-230). Carbondale: Southern Illinois University Press.

Dewey, J. (1927). The public and its problems. In J.A. Boydston (Ed.). The later works of John Dewey (Volume 2, pp. 235-372). Carbondale: Southern Illinois University Press.

Dewey, J. (1930). Individualism, old and new. In J.A. Boydston (Ed.). The later works of John Dewey (Volume 5, pp. 41-124). Carbondale: Southern Illinois University Press.

Dewey, J. (1934). Art as experience. In J.A. Boydston (Ed.). The later works of John Dewey (Volume 10, pp. 1-453). Carbondale: Southern Illinois University Press.

Dewey, J. (1935). Liberalism and social action. In J.A. Boydston (Ed.). The later works of John Dewey (Volume 11, pp. 1-66). Carbondale: Southern Illinois University Press.

Dewey, J. (1938a). Logic: The theory of inquiry. In J.A. Boydston (Ed.). The later works of John Dewey (Volume 12, pp. 1-528). Carbondale: Southern Illinois University Press.

Dewey, J. (1938b). Experience and education. In J.A. Boydston (Ed.). The later works of John Dewey (Volume 13, pp. 1-62). Carbondale: Southern Illinois University Press.

Dewey, J. (2015). Lectures in social and political philosophy. European Journal of Pragmatism and American Philosophy, 7(2), 45-180. 


\section{Kauppi, Holma and Kontinen}

Englund, H. (2004). Introduction: Recognizing identities, imagining alternatives. In $\mathrm{H}$. Englund \& F. Nyamnjoh (Eds.). Rights and the politics of recognition in Africa (pp. 1-29). London: Zed Books.

Freire, P. (2005). Pedagogy of the oppressed. New York: Continuum. (Original work published 1970).

Gaventa, J. (2004). Towards participatory local governance: Assessing the transformative possibilities. In S. Hickey \& G. Mohan (Eds.). Participation: From tyranny to transformation? Exploring new approaches to participation in development (pp. 25-41). London: Zed Books.

Goleman, D. (2006). Social intelligence: The new science of human relationships. New York: Bantam Books.

Holma, K. \& Kontinen, T. (2015). The rocky road of growth into contemporary citizenship: Dewey, Gramsci, and the method of democracy. Studier i Padagogisk Filosofi, 4(2), 24-37.

Holma, K. \& Kontinen, T. (2019). Practices and habits of citizenship and learning. In this volume.

Kaphagawani, D.N. (1998). African conceptions of personhood and intellectual identities. In P.H. Coetzee \& A.J.P. Roux (Eds.). Philosophy from Africa: A text with readings (pp. 169-176). London: Routledge.

Peirce, C.S. (1878). How to make our ideas clear. Popular Science Monthly, 12, 286-302.

Peters, M. \& Marshall, J. (1996). Individualism and community: Education and social policy in the postmodern condition. London: The Falmer Press.

Pettit, J. (2016). Why citizens don't engage - Power, poverty and civic habitus. IDS Bulletin, 47(5), 89-102.

Rydenfelt, K.H.O. (2019). Pragmatism, social inquiry and the method of democracy. In this volume.

Scheffler, I. (1974). Four pragmatists: A critical introduction to Peirce, James, Mead and Dewey. London: Routledge \& Kegan Paul.

Shor, I. \& Freire, P. (1987). A pedagogy for liberation: Dialogues on transforming education. Westport, CT: Greenwood Publishing Group.

Triandis, H.C. (1995). Individualism and collectivism: New directions in social psychology. Boulder, CO: Westview Press. 


\section{Part II}

\section{Localized practices and habits of citizenship}


$\Longrightarrow$ Taylor \& Francis

Taylor \& Francis Group

http://taylorandfrancis.com 


\title{
5 Contextualizing citizenship in Uganda
}

\author{
Henni Alava, Twine H. Bananuka, Karembe F. \\ Ahimbisibwe and Tiina Kontinen
}

\section{Introduction}

According to the pragmatist framework of this book, practices in which citizenship is constructed are embedded in certain environments and, accordingly, current citizenship habits have been formulated in the course of a continuity of experiences and in interaction with existing circumstances (Holma \& Kontinen, this volume). In this chapter, we provide a short overview of Uganda in so far as it is relevant for understanding the experiences and practices of citizenship: both vocal political engagement and the everyday processes of addressing matters of local importance. In contemporary Uganda, citizenship is manifest, on the one hand, in the upfront contestation and mobilization of visible opposition figures with increased popular support, and, on the other, continuously in mundane everyday life where problems are solved and shared issues are addressed together. The chapter thus contextualizes subsequent empirical chapters on gendered citizenship (Ndidde et al.), localized citizenship (Ahimbisibwe et al.), subdued citizenship (Alava) and critical education (Bananuka \& John) in Uganda, and provides inspiration for reflecting on prevalent liberal ideas of citizenship in light of lived experience of politics in the country. The chapter proceeds as follows: an overview of Ugandan history is followed by discussion of some of its contemporary characteristics, after which we conclude with reflection on the multiple spaces for citizenship learning in Uganda.

\section{Historical positioning: From pre-colonial kingdoms to the contemporary hybrid state}

In 1894, most parts of what is today known as Uganda was annexed as a British protectorate, and the emerging country remained under colonial rule until 1962. At independence, the subjects of the colonial government were transformed, by law, into citizens of the independent state of Uganda (Mamdani 1996/2004). Prior to the British annexation of Uganda as its protectorate, the area comprised numerous socially and politically heterogenous groups. These ranged from the hierarchically ruled and centralized kingdoms of Buganda, Bunyoro, Ankole 
and Toro, to communities in which leadership was dispersed among chiefs and lineage heads, as in the regions of Lango, Acholi, Madi, West Nile, and Karamoja (Babikwa 2005; Quinn 2014). In the pre-colonial kingdoms, leadership was largely autocratic, and power was bestowed upon certain individuals by right of birth. Local governance habits had emerged over long periods of time; the modern Kingdom of Buganda, for instance, was already established in the fourteenth century (Mutibwa 2008, 1). Accordingly, as Karlström (1996) shows, "customary" Baganda ideas of governance and politics continue to influence people's interpretations of contemporary politics, transcending, for instance, liberal deliberative democracy when long-standing cultural norms may give priority to civility or good manners.

Moreover, colonial power had far-reaching implications for citizenship constellations in Uganda today. The subjection of peoples from different kingdoms and clans to colonial rule instituted a notable departure from the ways in which societies had been organized. Colonial rule also intensified ethnic divisions in the area. Different areas had a different stand on being annexed to the British protectorate. For instance, the Buganda kingdom collaborated with the British and became a springboard for the expansion of colonial rule into Eastern Uganda (Mutibwa 2008). Some areas which resisted British occupation, such as Bunyoro and Acholi, were violently subjugated while others were peaceably annexed. Moreover, different regions were favoured by the British in terms of provision of resources and appointment to leadership positions. Colonial rulers considered the different peoples of Uganda to be suitable for different jobs, hence, while the northern parts of the country, in particular, gained military employment, the central and southern regions were the recipients of investment in high-quality education and industrial development.

In many areas, traditional chiefs were replaced with colonially appointed rulers. The British administration also applied the Bugandan model - based on a hierarchy of chiefs under a king - to the rest of the country (Mutibwa 2008 , 9). In order to empower chiefs to fulfil the tasks expected of them by the colonial government, such as tax collection, a system of "indirect rule" granted chiefs a breadth of power far beyond what they had previously had and effectively removed the checks and balances that had reigned in chiefly power in the pre-colonial era. In Mamdani's (1996/2004) terms, the pre-colonial systems in which chiefs had acted not only as rulers but also as patrons and caretakers of their subjects were replaced with decentralized despotism. The bolstering of ethnic identities and the creation of formidable regional socioeconomic divisions during the colonial era had long-lasting effects once Uganda gained independence.

\section{Post-independent Uganda: Struggles and changing regimes}

The first few years after independence were characterized by hope, enthusiasm and a booming economy. The Constitution of 1962 included a 
comprehensive Bill of Rights, and gave relative autonomy to the kingdoms, especially Buganda. However, by 1966, the socialist-leaning Prime Minister Milton Obote had suspended the Independence Constitution and, in 1967, instituted a new one that positioned him as executive president with immense powers (Halsteen 2004, 104). The Bugandan parliament resisted this act, whereupon the Buganda king was forced into exile in Britain following an attack on his palace by forces led by the army commander, Idi Amin. In 1971, Amin deposed Obote, and was initially welcomed with high expectations both in Uganda and Britain, a euphoria that swiftly vanished as Amin unleashed a reign of terror and dictatorship. A protracted struggle led by the combined forces of exiled Ugandans and Tanzanian forces overthrew Idi Amin in 1979 and, in a highly disputed election in 1981, Milton Obote regained power (Apter 1995).

The regimes of Obote I, Amin and Obote II were all criticized for favouring their own people and entrenching ethnic, regional and religious rivalries (Carbone 2003; Makara et al. 2009). Discontent with the increasing violence of Obote's second regime, most of which was perpetrated by his primarily northern Ugandan Acholi and Langi soldiers, culminated in the rise of resistance in what became known as the Bush War (1981-1986). At its core was the National Resistance Army (NRA; later renamed the National Resistance Movement, NRM) led by Yoweri Museveni. Initially, Museveni's troops consisted mainly of members of the Banyarwanda group, which has historically lived and migrated across the colonially established borders between Uganda, Rwanda, Burundi and DR Congo. Their orderly conduct and respect for civilians in the areas they controlled led the rebels to gain support from local populations in central and southern Uganda. As the rebellion gained momentum, so did Obote's troops' violent retaliations, most heatedly so in the Luwero Triangle north of the capital, Kampala, which again spurred support for the NRA.

A peace deal eventually struck between Obote and a number of rebel groups was short-lived, and in 1986 the NRA took over Kampala and established Museveni as president, a position which he has retained to this day. After years of chaos and violence, the new regime started a process of consolidating peace and nation-building. Museveni's takeover was seen by many Ugandans as providing much needed respite from the chaos that had characterized the preceding years (Tripp 2010, 1), yet experiences across the country diverged widely. In areas where Obote's soldiers had subjected the population to a reign of terror, Museveni was hailed as a saviour. In those parts of the north where Museveni's troops rounded up former soldiers and inflicted brutal retributive violence on the civilian population, the NRA was seen as a reign of terror. While the north continued to be drenched in waves of violent warfare between Museveni and rebel groups opposed to him - the Lord's Resistance Army in the Acholi region among the most long lasting - the south set out on a path of stabilization, economic growth and human development. This split in experiences of state power created two distinctly different realities co-existing within Ugandan borders (Shaw \& Mbabazi 2007). 
A new constitution was promulgated in 1995 following country-wide citizen consultation and participation in seminars, workshops, written memoranda and public debates (Halsteen 2004, 104). The constitution of 1995 legalized "movement democracy" and a political "movement system", thus diminishing hopes that some had held of introducing a multi-party system (Anderson \& Fisher 2016, 69; Rubongoya 2018, 102). The "non-party system" was supported by arguments that after the decades of brutal violence and ethnic conflicts, the country was not ready for politics based on contestation (Carbone 2003; Makara et al. 2009). While the NRM's stated claim has been that it is a movement of all citizens, without ethnic, regional or religious bias (Rubongoya 2018, 103), the top leaders of Museveni's regime largely hail from his home region in western Uganda (Tripp 2010, 25). Many of the tensions laid down during the colonial era thus continue to influence the present. In place of blanket statements about "Ugandan" experiences of citizenship, there is a need for historical and contextual nuance.

\section{Multi-party system and hybrid governance}

During the colonial era, education was largely in the hands of Catholic and Protestant (Anglican) missionaries, which led to the emergence of a political elite divided along religious lines. Four years prior to independence, the country's first political party, the Uganda National Congress (UNC), was formed with strong backing from the Protestant Church, whereas the majority of activists in the Democratic Party, formed shortly after the UNC, had Catholic backgrounds. Considering the violence of the first decades of Uganda's independence, Museveni's move to ban political parties on grounds of their perpetrating religious and ethnic sectarianism can thus be seen as an attempt to address a genuine problem. Political parties were only re-allowed in 2005, following donor pressure and an eventual public election (Rubongoya 2018, 106). What at first sight appeared a step towards democratization led, however, to new pressures on civic space. Many commentators agree that the old ideas of "divide and rule" on the basis of politicized identities such as religion and ethnicity have intensified during Museveni's time in power (Rubongoya 2018, 106; Tripp 2010, 25), and although opposition parties are allowed, they are treated as "enemies" to be side-lined or destroyed, rather than as political contestants (Rubongoya, 2018).

The most recent changes in legislation in 2017, pushed through parliament by Museveni and his dominant NRM members of parliament, have removed presidential age limits, paving the way for Museveni - already nominated in 2019 as NRM's sole candidate for the 2021 election - to remain in power without any constitutional restrictions. Contemporary Uganda is thus rightly characterized as a "hybrid regime", in which democratic or liberal structures of governance co-exist with non-democratic or authoritarian governance methods such as patronage, violence and repression (Tripp 2010, 1-3). This kind of hybrid regime, and the many contradictions and tensions that 
characterize it, provide the context for citizenship practices in Uganda today, especially when it comes to political participation and state-citizen relationships. Despite the multi-party system, in practice the NRM party retains such a tight hold on power that the state and the NRM are largely inseparable in the eyes of many Ugandan citizens (Alava \& Ssentongo 2016). In the following section we turn to some elements that characterize contemporary discussions on the citizenship environment in Uganda, which provide lenses for understanding the contexts of different citizenship practices, both in the vocally contested political sphere and in everyday life.

\section{Characteristics of citizenship environments}

Our historical overview pointed to the specificities that characterize citizenship in Uganda to date. In this section, we discuss four elements that we consider of relevance for shaping current citizenship practices: belonging, patronage, religion and violence.

\section{Belonging: Politicizing ethnicity}

In a country of diverse ethnic groups and over 52 spoken languages, one's place of origin and mother tongue and the particular cultural practices attached to diverse ethnicities are common topics of everyday conversations. Questions of belonging are also central to debates about citizenship - both as a right (to vote, to own property, to claim land), and as an identity (Bøås \& Dunn 2013). Claims to belonging can provide important arenas of participation and inclusion, but they also function as mechanisms of exclusion. While a universal notion of "Ugandan" citizenship has been hard to craft, the sphere in which "citizenship" has de facto taken place (Clarke et al. 2014) has been either the broader ethnic community, or closer membership in the community towards which one fulfils one's social responsibilities (Cheney 2008). In this vein, good citizenship can be understood as "residence" in a community (Ahimbisibwe et al., this volume; Ndidde et al., this volume). Therefore, while the rights-based discourse portrays citizens as individuals with rights to claim, lived experience can emphasize citizenship as good and responsible membership in a community. Yet, even when membership in the local community may be regarded as a privilege by that community's members, the question of who can stake claims on the state remains influential and has powerfully shaped Ugandan history.

The expulsion of Asians living in Uganda by Idi Amin in 1972 presents perhaps the most striking example of exclusions from citizenship. Yet less visible but equally striking disputes continue regarding, for instance, the question of when a migrant or refugee - and there are millions in Uganda becomes a Ugandan. The question of who belongs has in recent years also been waged on sexual grounds, with queer Ugandans - often condemned as "un-African" (Tamale 2009, 58) - calling to be accepted as full citizens of the 
country, with the same political rights and freedoms as everyone else (Valois 2015). Additionally, while Uganda has been at the forefront of women's movements in Africa (Tripp 2001; 2002), citizenship rights and experiences are gendered when it comes to the right to own land, to gain independent income, to fully participate in political decision-making or to have control of one's own sexuality (Tamale 2009, 53), especially in rural areas.

\section{Patronage: Loyalties and obligations}

The second element characterizing citizenship experiences in Uganda is the relationship between participation and patronage. The extent to which Ugandans have been able to participate in public affairs has historically fluctuated from violent subjection to colonial rule, to eras of dictatorship, to the current regime's initial (at least rhetorical) emphasis on broadened participation in decision-making at the grassroots level. Colonial administrators used small gifts and benefits to set subjects against each other in a manner that benefited the rulers, and post-independence leaders have continued to use patronage to stay in power and as a political bargaining tool (Green 2011; Rubongoya 2018, 108; Titeca 2018, 115). In Uganda, patronage is frequently used to gain support, using the provision of gifts and services in order to ensure personal support and loyalty. During electoral campaigning, candidates want to picture themselves as good patrons by offering gifts and money to potential voters. Although intensified in the run-up to elections, exercising patronage is an ongoing effort; members of parliament and the president himself are frequently shown visiting communities and providing money to fix an immediate problem such as the lack of a decent road or toilets in schools (Titeca 2018, 123).

Patronage implies citizenship experiences that revolve around showing loyalty to power holders, and expecting the "father of the nation", and other "big men" to provide something material in exchange; the NRM, for instance, is perceived by many people as a fountain of good things (Vokes \& Wilkins 2016). Such citizens' experiences are quite different from the vision of citizenship as holding the government accountable, or as participation in deliberation on political issues. Therefore, Uganda's patrimonial politics and personalized rule can be seen as a contrast to liberal democracy (Halsteen 2004, 110), and, from such a perspective, patronage has been argued to be one of the main constraints on democratization (Hickey \& King 2016).

\section{Religion: Towards moral orders of citizenship}

In Uganda, religion plays an important role both in national politics and in local mobilizing. The most enduring effect on the political sphere has come from the Catholic and the Protestant (Anglican) Churches, which have until recently been the largest in the country. While, on the one hand, they have created inter-ethnic allegiances, they have also functioned as sources of 
division (Wasswa-Kintu 1995). Throughout the colonial and much of the post-colonial era, churches were the primary conduits between the state and citizens, and the primary provider of many social services, including education (Alava \& Shroff, 2019). Despite its formal opposition to religion, Obote's reign entrenched the division between the Anglican Church, which functioned as a de facto state church, and the Catholic Church, which was pushed into opposition despite its majority status.

Museveni's disbanding of earlier political parties, the two biggest of which were closely connected with the Uganda's largest churches, transformed the public role of religion: the churches' direct ability to influence politics decreased, yet they maintained a notable capacity to mobilize people at the local and national levels, with religious leaders employing their highly visible positions to take part in and influence public debates (Alava \& Ssentongo 2016). At the local level, alongside the activities of religious leaders, many of whom are respected as public authorities, a variety of local church groups exist to provide arenas for participation in parish decision-making and in various development initiatives - examples include parish councils, the Mother's Union of the Anglican Church and the Roman Catholic Church's Small Christian Communities. In Kassimir's view, these groups have limited effect in promoting transformation in civil society, partly because they have largely been established by missionaries or by local clerics rather than by local initiative (Kassimir 1998). Yet, despite such limitations, other observers note that churches in general must be acknowledged as deeply meaningful arenas for organizing at the local level (Jones 2009).

Particularly since the 1980 s, a key arena for collective mobilizing and organizing has developed around charismatic religious expression, both concerns over witchcraft and spirit possession, and over the apparent failure of the state and the moral corruption of society. This is an energy that the structures of mainline churches have largely been unable to capture for their own mobilization. Furthermore, it evidences understandings of "civility" that may be highly different to those implied by West-centric understandings of "civil society" (Kassimir 1998). Meanwhile, increasingly politicized Pentecostal/Charismatic forms of Christianity are articulating ideals of citizenship that are profoundly shaped by religious idioms and moral projects (Bompani \& Valois 2017). The growth of these movements' public influence has spread a concern about morality to all segments of public debate, whereby notions of what constitutes a "good citizen" in Uganda have increasingly turned into questions of morality (Gusman 2009).

\section{Violence: Militarization of the polity}

Ugandan post-colonial history has been characterized by what Anderson and Fisher $(2016,68)$ refer to as a general "militarization of the polity": the fusion of military and political power centralized around the president. Ugandan military and security services played a key role in ensuring support for 
Museveni's regime during the elections in 2001, which were characterized by outbursts of violence. Moreover, the police and army frequently harass and arrest assemblies of oppositional parties, as well as protesters addressing any issue in demonstrations or journalists covering such events (ibid., 80). This activity is partly enabled by the Anti-Terrorist Act of 2002 that gave security agencies a lot of power. Museveni's hold on power owes much to the, at times, brutal violence meted out by the army and special forces under the command of his younger brother, and to networks of informants that are commonly believed to have infiltrated all institutions, from village councils and churches to universities (Tapscott 2017). It has been argued that international donors have (often indirectly) strengthened the Ugandan military, and, thus, supported the authoritarian and violent regime (Anderson \& Fisher 2016, 68). Uganda's remarkable role in peacekeeping in the region has also enabled international military support to be flown into the country.

Moreover, during the first decade of NRM rule, it sought to secure full control all over the country in the face of protesting rebel groups. In that period, Local Defence Units (LDUs) were set up, and training schools of mchakamcaka were established under the NRM to train citizens in basic defence skills and inculcate political values in civilian participants in order to legitimate NRM power, with the argument that all citizens should be able to defend themselves against the future abuses of a tyrannical leader (Rubongoya 2018, 100). Such programs were compulsory for all citizens, and every morning "hundreds of thousands of Ugandans could be seen marching with wooden guns and chanting pro-NRM slogans" (Tripp 2010, 77). Clearly, a very specific kind of good citizenship is learned in militarized citizenship education of the type conducted by the NRM; loyalty to the party and to the nation, combined with the violent underpinnings of the training, come to shape understandings of what citizenship means (Verma 2013).

\section{Spaces for learning citizenship}

In any country, the formal education system plays an important role not only in provision of basic literacy and numeracy skills, but also in nation-building and the creation of a sense of citizenship. Moreover, civil society, both in the form of established civil society organizations (CSOs) and citizens' own associations cohering around shared issues, provide opportunities for learning citizenship.

\section{Educational system}

Uganda is an example of the current "crisis of learning" (World Bank 2018): while access to basic education has increased substantially, the learning outcomes in even the most basic skills have been low. The lack of skills such as literacy hampers the competence of citizens to participate actively and to hold the government accountable, thereby fulfilling the current ideals of citizenship 
engagement (Gaventa \& Barrett 2012). In Uganda, complexities in the education system partly result from its history. While in pre-colonial Uganda, ideals of "good citizenship" were passed from generation to generation through informal education, Christian missionaries and colonial administrators introduced a very different education system. At the time, the indigenous education was considered backward and incapable of transforming individuals into "good citizens", suitable for a colonial society (Opio-Odongo 1993; Ssekamwa 1997; Nabayego 2013).

Becoming a "good citizen" of colonial Uganda was fundamentally about becoming "civilized" through conversion to Christianity and acquiring a colonial education. These "reformed" natives, who adopted the dress, language and religion of their colonial masters, were considered a rank above other natives, and were encouraged to adopt an attitude of condescension towards their "uncivilized" fellow citizens (see p'Bitek 1972). The division between what emerged as a "civilized" and increasingly urban middle class and the less-educated rural population remains a profound characteristic of the landscape of Ugandan citizenry today. Moreover, Uganda's current education system has remained largely a copy of the British system, which partly decreases its relevance in the Ugandan societal context (Nabayego 2013; Datzberger 2018).

In post-independent Uganda, Obote's regimes espoused a formally leftist ideology, in line with which he nationalized schools, effectively pushing churches out of their most important arena for training what they considered "good citizens". In Amin's era, education was seriously disturbed by the chaos and violence. Against this backdrop, the new regime focused on stability immediately after 1986; education was not their first priority and it was not until 1997 that Uganda adopted Universal Primary Education (Oloka-Onyango 2009, 98). International donors have influenced the trends in education and, despite the kind of indigenization of education proposed in 1992 (Government of Uganda 1992), the content and structure of the education system have not changed much. With global neoliberalization, Uganda's education sector has encountered commodification, and higher education in particular has been privatized (Opio-Odongo 1993; Mamdani 2007; Kasozi 2003).

In general, there are large quality differences at each level, while, although primary education is technically free, many hidden costs hinder the attendance of the poorest pupils (Datzberger 2018, 135). Moreover, even secondary education does not seem to provide competence in critical and active citizenship. For instance, a recent study by Datzberger and Le Mat (2019) on the politically empowering elements learned in secondary schools, such as critical reflection and participation in communal life, showed that almost half the respondents, from various parts of the country, felt that they do not have a clear understanding of Uganda's political system (ibid., 23). For a citizen, it is challenging to participate in or engage with a system that one does not understand. This was accompanied by accounts that while some social problems are discussed at school, there is not much critical reflection of the core 
reasons for them nor of Uganda's own history (ibid., 24). In general, the approach to education is geared towards assimilation rather than transformation (Datzberger 2018, 135), and therefore, the "good" citizenship which is taught principally involves contributing to, and aligning with, the existing system rather than contesting it.

\section{Civil society and everyday organizing}

The local council system that structures local governance is intended to provide ordinary citizens with a meaningful participatory arena in which to accrue citizenship competence. Despite its challenges with patronage, the system has been vital in promoting women's political participation, among other things. Outside the government structures, citizens' participation and organizing around shared issues can take place in a range of CSOs from large national NGOs to local membership-based associations.

CSOs, having gained prominence since the 1970s (Deniva 2006; Fourie \& Kakumba 2011), are involved in direct citizenship education that often increases shortly before elections, but then is cut off afterwards (ConroyKrutz 2016), programs that strengthen the realization of rights and promote social accountability. Moreover, in Uganda, the environmental and women's movements have been especially successful in both mobilizing citizens and influencing legislation (Tripp 2010, 105). All the forms of association that can be identified in contemporary Uganda have roots in historical precedents of association, but changes in them have also been affected by broader dynamics beyond Uganda, such as the international human rights and women's movements, as well as donor funding (Tripp 2002).

Yet, from the very beginning, the ability to act of all civil society actors from the women's movement to local councils - has been curtailed; citizens could secure the benevolence of the NRM regime only by moderating their claims and shifting their activities into the most apolitical and non-contentious arenas possible (Dicklitch \& Lwanga 2003). A key component in this dynamic has been patronage: for instance, within the women's movement, presidential patronage strengthened the ability of individual women to voice their concerns in curtailed political arenas, yet simultaneously watered down the movement's efforts to create sustainable platforms for mobilizing (Goetz $\&$ Hassim 2002). The expansion of civic space was also short-lived. Soon after coming to power, Museveni reversed his position on the criteria for conferring citizenship and rights for those living in Uganda from an emphasis on residence back to one on descent (Mamdani 2002).

Local mobilization in membership organizations, such as village savings and loans groups (see Ndidde et al., this volume), produces a significant forum in which citizenship takes place (Clarke et al. 2014). Moreover, people organize around cultural festivities, and events such as marriages and funerals, to which everyone contributes according the agreed rules. The constellation of rights and responsibilities that revolve around such life span 
activities differ from liberal ideas of citizenship, but are, nevertheless, highly appreciated. Moreover, from the point of view of grassroots citizenship, the intertwining of participation and livelihood concerns are important. As shown by Hickey and King (2016; King 2015) in their studies in the subregion of Rwenzori, successfully initiating change should not be so much about promoting liberal democracy, as identifying and strengthening intermediate mechanisms, such as small-holder and producer groups where people engage in solidaristic networks in everyday efforts related to livelihoods.

\section{Conclusions}

The project of nation-building, so crucial in Western theories of citizenship, has unfolded in Uganda, as in other multi-ethnic post-colonial contexts, in ways hardly envisioned by those theories. In these contexts, even more than in apparently mono-ethnic "nation states", the notion of "nation" is in its essence a product of the imagination - one created and constantly maintained through complex cultural production and through violence (Anderson 2006). The regional, ethnic and religious divisions, and the unequal structures of power that were built into Uganda during the colonial era continue to affect contemporary experiences of what it means to be a Ugandan.

The coming to power of the incumbent president, Yoweri Museveni, was greeted as a new start by many Ugandans, and by the country's international donors, who for many years considered Uganda a "success story" of political and economic liberalization (Wiegratz et al. 2018; Anderson \& Fisher 2016, 68). Yet, in recent years, the initial promise of Uganda's transformation into a liberal success story has faded. Even though on many counts today's Uganda is more stable than at the beginning of the present regime in 1986, the past decade has been characterized by increasing restrictions on political freedom, the expansion of executive power and limits on the independence of the judiciary (Tripp 2010, 36-37). While these restrictions have not stopped Ugandans from confronting the regime, they do constrain the manifestations of vocal citizenship, as demonstrations and opposition rallies are met with harsh police and military response, followed by arrests and court cases. Both longerterm histories and recent developments in the Ugandan state have created a different citizenship environment to that assumed in liberal notions of citizenship. However, the ideal of liberal democracy and a very particular type of active citizenship holds a strong place in donor policies and NGO interventions.

In the everyday lives of Ugandan citizens, identification with ethnic groups, one's immediate community or religious organizations, can offer a much stronger sense of citizenship - both as belonging and as engaging with rights and responsibilities - than the sentiment of belonging to the nation. Consequently, as much of the joint organizing in the former sphere is geared towards solving local problems, arranging funerals and weddings and combining forces in agricultural production, active participation in politics or 
lobbying the government for accountability might not attract much attention nor energy. Relations between citizens and the state continue to be characterized by the logics of patronage, wherein leaders enlist support and ensure the loyalty of participating citizens through personal gifts and services, thereby undercutting the chances for political deliberation and citizens' mobilization, especially in the vast rural population. There thus appears to be a tension between human rights-based discourses of citizenship in Uganda - which emphasize that individuals have rights based on their humanity - and certain culturally valued conceptualizations of the good life, which emphasize that human beings grow into their status as full members of the community by fulfilling their responsibilities towards that community (Cheney 2008).

In conclusion, when reading accounts of contemporary citizenship practices and habits, we should keep in mind that experiences of citizenship emerge out of particular histories in particular localities and are moulded by ethnicity, gender and other contextual issues. The practices of citizenship that thus ensue may differ noticeably from whatever ideal images we might have about active citizenship.

\section{Box 5.1 Facts about Uganda}

Population (projection, 2017): 42.9 million

Urban population (2017): $23.2 \%$

Area: $241551 \mathrm{~km}^{2}$

Capital city: Kampala

Official languages: Kiswahili, English

Governance: Republic, executive president, multiparty system

Literacy rate (2012): 70.2\% (15 years and older)

Life expectancy (at birth) (2018): 60.2 years. Female 62.4 years, Male 58.0 years

Infant mortality (2016): 37.7/1000 live births

Employment percentage (estimate, 2017): 69.2\% (15 years and older)

Religions (2014): Christian (84.5\%), Muslims (13.7\%), Traditional religions (0.1\%), Other religions (1.4\%), Irreligion (0.2\%).

Ethnical groups (2014): Baganda (16.5\%), Banyankore (9.6\%), Basoga (8.8\%), Bakiga (7.1\%), Iteso (7.0\%), Langi (6.3\%), Bagisu (4.9\%), Acholi (4.4\%), Lugbara (3.3\%), Other (32.1\%).

Human Development Index (2018): Value 0.516 (Rank 162)

Civic space: Repressed

Freedom house indicators (value 100 most free, value 1 most free, 7 least free):

Aggregate freedom score: $36 / 100$

Freedom rating: $5.5 / 7$

Political rights: $6 / 7$

Civil liberties: $5 / 7$ 


\section{Governance indicators (2017) (100 is the highest rank):}

Voice and accountability: $31 / 100$

Political stability and absence of violence: $27 / 100$

Government effectiveness: $32 / 100$

Regulatory quality: 46/100

Rule of law: $42 / 100$

Control of corruption: $14 / 100$

\section{Sources}

Civicus (2019). Uganda. Retrieved from https://monitor.civicus.org/country/ uganda/

The Commonwealth (n.d.). Uganda. Retrieved from http://thecommonwealth. org/our-member-countries/uganda

Freedom House (n.d.). Freedom in the World 2019: Uganda. Retrieved from https://freedomhouse.org/report/freedom-world/2019/uganda

Uganda Bureau of Statistics (2016). The National Population and Housing Census 2014 - Main Report. Kampala. Retrieved from www.ubos.org/onlinefiles/uploads/ubos/NPHC/CENSUS\%20FINAL.pdf

UNDP (n.d.). Uganda. Human Development Indicators. United Nations Development Programme. Human Development Repots. Retrieved from http://hdr.undp.org/en/countries/profiles/UGA

The World Bank Group (2019). Worldwide governance indicators: Interactive data access. Retrieved from http://info.worldbank.org/governance/wgi/index. aspx\#reports

\section{References}

Ahimbisibwe, K.F., Ndidde, A.N. \& Kontinen, T. (2019). Participatory methodology in exploring citizenship: A critical learning process. In this volume.

Alava, H. \& Shroff, C. (2019). Unravelling church land: Transformations in the relations between church, state and community in Uganda. Development \& Change: 50(5), 1288-1309. https://doi.org/10.1111/dech.12503

Alava, H. \& Ssentongo, J.S. (2016). Religious (de)politicization in Uganda's 2016 elections. Journal of Eastern African Studies, 10(4), 677-692.

Anderson, B. (2006). Imagined communities: Reflections on the origin and spread of nationalism. London: Verso.

Anderson, D.M. \& Fisher, J. (2016). Authoritarianism and the securization of development in Uganda. In T. Hagman \& F. Reyntjens (Eds.). Aid and authoritarianism in Africa (pp. 67-90). London: Zed Books.

Apter, D.E. (1995). Democracy for Uganda: A case for comparison. The Quest for World Order, 124(3), 155-190. 
Babikwa, D. (2005). The political economy of adult education in Uganda. In A. Okech (Ed.). Adult education in Uganda: Growth, development, prospects and challenges (pp. 35-50). Kampala: Fountain Publishers.

Bøås, M. \& Dunn, K.C. (2013). Politics of origin in Africa: Autochthony, citizenship and conflict. London: Zed Books.

Bompani, B. \& Valois, C. (2017). Christian citizens and the moral regeneration of the African state. London: Routledge.

Carbone, G.M. (2003). Political parties in a 'no-party democracy': Hegemony and opposition under 'movement democracy' in Uganda. Party Politics, 9(4), 485-501.

Cheney, K.E. (2008). Pillars of the nation: Child citizens and Ugandan national development. Chicago, IL: University of Chicago Press.

Clarke, J., Coll, K., Dagnino, E. \& Neveau, C. (2014). Disputing citizenship. Bristol: Policy Press.

Conroy-Krutz, J. (2016). Electoral campaigns as learning opportunities: Lessons from Uganda. African Affairs, 115(460), 516-540.

Datzberger, S. (2018). Why education is not helping the poor. Findings from Uganda. World Development, 110, 124-139.

Datzberger, S. \& Le Mat, M. (2019). Schools as change agents? Education and individual political agency in Uganda. International Journal of Educational Development, 67, 18-28.

Deniva (2006). Civil society in Uganda: At the crossroads? (Civicus Civil Society Index Project). Kampala. Retrieved from www.civicus.org/media/CSI_Uganda_Country_ Report.pdf

Dicklitch, S. \& Lwanga, D. (2003). The politics of being non-political: Human rights organizations and the creation of a positive human rights culture in Uganda. Human Rights Quarterly, 25(2), 482-509.

Fourie, D.J. \& Kakumba U. (2011). Assessing the role and capacity of civil society organisations in holding local government accountable in Uganda. African Journal of Public Affairs, 4(2), 55-65.

Gaventa, J. \& Barrett, G. (2012). Mapping the outcomes of citizen engagement. World Development, 40(12), 2399-2410.

Goetz, A.M. \& Hassim, S. (2002). In and against the party: Women's representation and constituency-building in Uganda and South Africa. In M. Molyneux \& S. Razavi (Eds.). Gender justice, development, and rights (pp. 306-344). Oxford studies in democratization. New York: Oxford University Press.

Government of Uganda (1992). Government white paper on education. Entebbe: UPPT.

Green, E. (2011). Patronage as institutional choice: Evidence from Rwanda and Uganda. Comparative Politics, 43(4), 421-438.

Gusman, A. (2009). HIV/AIDS, Pentecostal churches, and the 'Joseph Generation' in Uganda. Africa Today, 56(1), 67-86.

Halsteen, U. (2004). Taking rights talk seriously: reflections on Ugandan political discourse. In H. Englund \& F.B. Nyamnjoh (Eds.). Rights and the politics of recognition in Africa (pp. 103-124). London: Zed Books.

Hickey, S. \& King, S. (2016). Understanding social accountability: Politics, power and building new social contracts. The Journal of Development Studies, 52(8), 1225-1240.

Holma, K. \& Kontinen, T. (2019). Practices and habits of citizenship and learning. In this volume.

Jones, B. (2009). Beyond the state in rural Uganda. Edinburgh: Edinburgh University Press for the International African Institute. 
Karlström, M. (1996). Imagining democracy: Political culture and democratisation in Buganda. Africa, 66(4), 485-505.

Kasozi, A.B.K. (2003). University education in Uganda: challenges and opportunities for reform. Kampala: Fountain Publishers.

Kassimir, R. (1998). The social power of religious organization and civil society: The Catholic Church in Uganda. Commonwealth \& Comparative Politics, 36(2), 54-83.

King, S. (2015). Political capabilities for democratisation in Uganda: Good governance or popular organization building? Third World Quarterly, 36(4), 741-757.

Makara, S., Rakner, L. \& Svåsand, L. (2009). Turnaround: The national resistance movement and the reintroduction of a multiparty system in Uganda. International Political Science Review, 30(2), 185-204.

Mamdani, M. (2002). African states, citizenship and war: A case-study. International Affairs, 78(3), 493-506.

Mamdani, M. (2004). Citizen and subject: Contemporary Africa and the legacy of late colonialism. Kampala: Fountain Publishers. (Original work published 1996).

Mamdani, M. (2007). Scholars in the market place: The dilemmas of neoliberal reform at Makerere University, 1989-2005. Kampala: Fountain Publishers.

Mutibwa, P. (2008). The Buganda factor in Ugandan politics. Kampala: Fountain Publishers.

Nabayego, C. (2013). Suggestions for improving Ugandan higher education to produce productive graduates. Makerere Journal of Higher Education, 4(2), 261-277.

Ndidde, A.N., Ahimbisibwe, K.F. \& Kontinen, T. (2019). Gendered citizenship in rural Uganda: Localized, exclusive and active. In this volume.

Oloka-Onyango, J. (2009). NGO struggles for economic, social, and cultural rights in UTAKE: A Ugandan perspective. In M. Mutua (Ed.). Human rights NGOs in East Africa. Political and normative tensions (pp. 75-111). Kampala: Fountain Publishers.

Opio-Odongo, J.M.A. (1993). Higher education and research in Uganda. Nairobi: Acts Press.

p'Bitek, O. (1972). Song of Lawino and Song of Ocol. Nairobi: East African Publishing House.

Quinn, J.R. (2014). Tradition?! Traditional cultural institutions on customary practices in Uganda . Africa Spectrum, 49(3), 29-54.

Rubongoya, J.B. (2018). 'Movement legacy' and the neoliberalism as political settlement in Uganda's political economy. In J. Wiegratz, G. Martiniello \& E. Greco (Eds.). Uganda: The dynamics of neoliberal transformation (pp. 95-110). London: Zed Books.

Shaw, T.M. \& Mbabazi, P.K. (2007). Two Ugandas and a 'liberal peace'? Lessons from Uganda about conflict and development at the start of a new century. Global Society, 21(4), 567-578.

Ssekamwa, J.C. (1997). History and development of education in Uganda. Kampala: Fountain Publishers.

Tamale, S. (2009). Law, sexuality, and politics in Uganda: Challenges for women's human rights NGOs. In M. Mutua (Ed.). Human rights NGOs in East Africa: Political and normative tensions (pp. 51-74). Kampala: Fountain Publishers.

Tapscott, R. (2017). The government has long hands: Institutionalized arbitrariness and local security initiatives in Gulu, northern Uganda. Development \& Change, 48(2), 263-285. 
Titeca, K. (2018). More is less? Decentralisation and regime control in neoliberal Uganda. In J. Wiegratz, G. Martinello \& E. Greco (Eds.). Uganda: The dynamics of neoliberal transformation (pp. 111-126). London: Zed Books.

Tripp, A.M. (2001). The politics of autonomy and cooptation in Africa: The case of the Ugandan Women's Movement. The Journal of Modern African Studies, 39, $101-128$.

Tripp, A.M. (2002). The politics of women's rights and cultural diversity in Uganda. In M. Molyneux \& S. Razavi (Eds.). Gender justice, development, and rights (pp. 413-440). New York: Oxford University Press.

Tripp, A.M. (2010). Museveni's Uganda: Paradoxes of power in a hybrid regime. Boulder, CO: Lynne Rienner Publishers.

Valois, C. (2015). Virtual access: The Ugandan 'anti-gay' movement, lesbian, gay, bisexual and transgender blogging and the public sphere. Journal of Eastern African Studies, 9(1), 145-162.

Verma, C.L. (2013). Guns and tricks: State becoming and political subjectivity in wartorn northern Uganda. (Doctoral Dissertation, University of Copenhagen, Denmark). Retrieved from https://anthropology.ku.dk/PhD/thesis/

Vokes, R. \& Wilkins, S. (2016). Party, patronage and coercion in the NRM'S 2016 reelection in Uganda: Imposed or embedded? Journal of Eastern African Studies, 10(4), $581-600$.

Wasswa-Kintu, J.A. (1995). Constraints to post-colonial economic development in Uganda 1962-1995: A political interaction approach (Masters' Thesis, Simon Fraser University, Burnaby, BC, Canada). Retrieved from https://core.ac.uk/download/pdf/ 56371039.pdf

Wiegratz, J., Martiniello, G. \& Greco, E. (Eds.). (2018). Uganda: The dynamics of neoliberal transformation. London: Zed Books.

World Bank (2018). World Development Report 2018: Learning to realize education's promise. Washington, DC: World Bank. Retrieved from http://www.worldbank.org/ en/publication/wdr2018 


\title{
6 Contextualizing citizenship in Tanzania
}

\author{
Ajali M. Nguyahambi, Haji H. Chang'a, Benta N. \\ Matunga, Rehema G. Kilonzo and Tiina Kontinen
}

\section{Introduction}

In order to explore citizenship habits, it is important to examine the circumstances and environments in which they have been formulated and where they are currently exercised (Holma \& Kontinen, this volume). The circumstances relevant for our purposes include both the historically evolved societal and political environments where citizenship is practiced, and the forums of citizenship learning that shape these ideas and practices. In this chapter on Tanzania, we approach them through the notion of maendeleo (in Swahili lit. "development"), which is continuously used in public discourses to emphasize the roles and responsibilities of the state and its citizens. From the point of view of citizenship practices, the idea of maendeleo does not only define the explicitly political features of citizenship, it also affects everyday participation and how shared issues are addressed.

In contemporary Tanzania, maendeleo is not a new term, as it was central before, during and after independence in 1961. Tanzania has passed through different phases of leadership and plans; however, in each phase the main issue has been development for the people. In recent years, the slogan, "maendeleo hayana chama" (development has no political affiliation), has increasingly become popular, especially with government officials and the ruling party - the Chama cha Mapinduzi (CCM) - emphasizing that development is meant for everyone regardless of political affiliation. In addition, it denotes the specific political orientation of the state and the expected, "unpolitical" form of citizens' participation in governance and development processes. Further, this discourse has emphasized the role and responsibilities of ordinary citizens in contributing to development, portrayed as the task of every individual in the country. Consequently, in Tanzania, strong contestations over citizenship rights and roles have not been prevalent; rather, citizenship has been exercised more or less within the framework defined by the governing political party: first during the single-party era of African socialism, and second, after the re-introduction of multiparty politics in 1992. Overall, citizenship in Tanzania has been characterized by phases of decolonization, post-independence nation-building and one-party African socialism, 


\section{4}

Nguyahambi et al.

with later liberalization of the economy and re-introduction of multiparty politics with regular elections (Aminzade 2013).

In planning development, the focus has been on technical issues and formal institutions, with the construction of citizenship taking place simultaneously in diverse situations. While a large number of different ethnic groups live in Tanzania, the consolidation of Kiswahili as a national language has strengthened shared "Tanzanian" values in the belonging and identity of its citizens (Rwengabo 2016; Kessler 2006). Moreover, the educational system prioritizes training people to become good citizens through the school curriculum, moulding individuals into responsive citizens who will participate in their own development. In the post-independence decades, education in general and adult education in particular has been a valued way to strengthen the competencies and commitment of citizens. Citizenship learning has taken place in multiple spaces and places such as the formal school system, official civic education and through practical learning in civil society and everyday life.

In this chapter, we provide an understanding of Tanzanian history and the contemporary moment through the lenses of development, citizenship and learning. We first revisit pre-colonial history and the birth of the nation, discussing the emergence of the discourse of maendeleo in nation-building in a single-party era. Following that, we reflect on the implication of the introduction of multiparty politics, highlighting contemporary aspects related to citizenship.

\section{Independence and the birth of a nation}

Like most of the African countries, Tanzania's history is intertwined with colonialism. Contemporary mainland Tanzania, Tanganyika, was initially part of German East Africa (1885-1918), and then a British colony until 1961. The ways in which these two different colonial powers established their relationship with their subjects (rather than citizens) have shaped the habits and structures of governance until today (Schneider 2006). In the pre-colonial era, communities in Tanganyika aligned in political and societal structures based on traditional arrangements according to the different ethnic groups established in the chiefdoms. During the colonial era, the Germans supported the Swahili culture, establishing a government school system along the coast with Swahili as the language of instruction; consequently, coastal leaders cooperated with the German colonial administration. The British, on the other hand, exercised "indirect rule" (Schneider 2006, 98) through pre-existing chiefs who would do their bidding, hence favouring the larger ethnic groups, such as Chagga (in Kilimanjaro) and Sukuma (in Shinyanga and Mwanza), over the small ones (Mpangala 1992). Given the environment of potential ethnic and tribal divisions created by the British colonial regime, pre-independence movement leaders preferred to employ associations capable of bringing together different ethnic groups. Thus, they organized their struggles through the Tanganyika African Association (TAA) and later the 
Tanganyika African National Union (TANU), which had already assumed a national character, to attaining political independence in December 1961.

Soon after this, Tanganyika embarked on a nation-building project that ranged from altering existing British colonial policies to radically departing from them, with the Arusha Declaration in 1967 providing the framework of implementation. Nation building was guided by the policy of Ujamaa socialism - which encouraged citizens to participate in communal activities in their respective villages - and was an overtly top-down political project that aimed to address ethnic divisions created during the colonial period and create a sense of national unity. The purpose was to inculcate citizens with desirable political ideals, that is, a strong attachment to the nation that transcended ethnic and regional identities. Nation building was thus meant to foster national identity (Aminzade 2013), which was required due to the multiethnic nature of the political society. Additionally, explicit efforts to reduce divisions on the basis of religion were made; the secularity of the state was announced from the beginning and the independent government promised equality for all religions. This is the background for discontent among religious activists (i.e. Muslims) who often complain about "unequal opportunities" in education and government employment compared with the Christian population (Liviga \& Tumbo-Masabo 2006; Bakari \& Ndumbaro 2001).

The nation-building project involved the establishment of associational bonds across ethnic groups alongside the adoption and experimentation of progressive social policies. For example, Ujamaa villages were created in order to facilitate the provision of shared common resources and social services, as well as making it easier to mobilize them politically. Among others, the nation-building project was meant to consolidate social cohesion, which was considered important in sustaining collective community projects. Nation building required state power and resources to enforce (Rwengabo 2016), and the first president of the country, Julius Kambarage Nyerere (1961-1985) provided leadership agency in the implementation of the project. It started in the early years of independence with the goal of cultivating national cohesion by integrating populations into the emerging state apparatus wherein a common identity was claimed. Thus, today's national citizenship identity resulted from a deliberate domestic process, which was politically top-down rather than the result of spontaneous actions initiated by the people.

Despite the multiplicity of ethnic groups in postcolonial Tanganyika, the nation-building project managed to develop a relatively coherent identity - in comparison to Uganda, for instance (Alava et al., this volume) - through a fusion of sub-national and ethnic social identities. As a move towards establishing a centralized government legitimized by the goal of building cohesion and national identity (Pratt 1981) all unions based on ethnic identity were abolished and religious associations were warned to stay out of politics. This was when the chiefdom system was banned and the potential discontent of influential chiefs controlled by giving them civil service posts. Consequently, 
nation building acquired shared cultural resources and symbols such as the Swahili language, which served as an ideological and political communication tool. In addition, nation building achieved the loyalty of populations to the same geo-political unit, and the elimination of ethnic dominance over political institutions (Miguel 2004). Overall, post-independence nation-building in Tanzania is generally regarded as a success, as Tanzania has avoided the seriously violent ethnic and religious conflicts prevalent in many other African countries.

\section{The emergence and formulations of "maendeleo"}

The notion of maendeleo, development - considered one of the strongest pillars in the nation-building project - was embedded in the post-independence policies of Ujamaa na Kujitegemea (familyhood and self-reliance). Ujamaa as a political notion denoted a strong sense of communal spirit, a sense of belonging and the assumption of mutual responsibility for societal development, which was explicitly related to traditional African values (Stöger-Eising 2000). In this respect, it constituted a societal project: African socialism that combined nation-building policies with social and economic development strategy. Hence, Ujamaa offered a distinct set of egalitarian principles that formed the bedrock of values and efforts to institute profound social change in collective ways of living, directed and shaped by the state.

The Ujamaa philosophy promoted the total participation of all community members in communal labour in the rural sector, communal ownership of land, nationalizations in the private sector and the provision of public services such as health and education at the national level (Jennings 2017). As such, citizens' participation in development activities was to be realized through mutual help and voluntary engagement in everyday community life. Indeed, notwithstanding the rhetoric of voluntarism, Ujamaa community members had an obligation to work, which took the form of cooperation in production and sharing in distribution (Stöger-Eising 2000). Therefore, a communalized work force and collectivized means of production were the cornerstones of maendeleo; people who were reluctant to participate in communalized development activities in Ujamaa villages were referred to as parasites (kupe in Swahili).

The rights and duties of citizens were defined alongside the kind of education that aimed to transmit values compatible with the creation of an egalitarian society. In order to ensure the effective implementation of the Ujamaa policy and attainment of its egalitarian goals, a powerful bureaucracy was installed to take control of its management. The policy was part of the Arusha Declaration of 1967, which was a concrete set of prescribed leadership codes, such as "freedom", "justice" and "unity", to be adopted by political officials and bureaucrats. The Tanganyika African National Union (TANU), which was the only political party within the single-party 
system, was entrusted with a supervisory role and leadership. The Ujamaa policy advocated state-led development that emphasized nation building and nationalism (Hyden 1981). Therefore, Ujamaa as the framework for the path of development in Tanzania denotes a specific ideological focus in the promotion of nationalism, the transformation from colonial hegemony to a meaningful sense of nationhood and citizenship, and African particularism in a socialistic form of governance. State-led implementation of the Ujamaa policy germinated into "developmental paternalism" (Pratt 1981; Schneider 2006), hence embedding Ujamaa in the rise of an authoritarian state that was supposed to take a paternalistic care of the development of its citizens. Although Nyerere (1968) elaborated on the connections between development and the participation of people in the communities, the realization of expected outcomes started to dwindle as the government largely took over the responsibility of development without much involving the grass roots level.

Different mechanisms were employed to implement the nation-building project, including the adoption of Kiswahili as a national language, the presence of civic curricula in schools and the official use of national symbols and slogans. In addition, some specific laws were made to promote national unity and discourage divisiveness. The nationalism discourse was monopolized by the ruling party, TANU (later CCM), through widespread party branches in all villages, schools, public services, major industries, major civic groups and trade unions (Mmuya \& Chaligha 1994). The population was mobilized to extremely high levels of support for the party, notwithstanding the generally passive roles occupied by ordinary people, while the government controlled political expression, political organization and the message of nation building. The primary objective of the government was to address three declared enemies (ignorance, diseases and poverty), hence it limited any potential voices of dissent or alternative nationalizing narratives (Nyerere 1962; 1968). Those who did not participate in the national building project were considered traitors, which helped to guarantee the involvement and support of every citizen in development projects, across classes, races, ethnicities and gender. The limited space for political expression and organization, however, produced a post-colonial citizenship agenda that was political and propagandistic rather than focused on citizenship rights and corresponding duties. Citizens became mere receivers of party policies and instructions, which they were to support and implement whenever they got the opportunity (Lawson \& Rakner 2005; Komba 1996).

State institutions managed the citizenship education agenda during the post-colonial era. President Julius Nyerere spearheaded nation-wide civic education through his speeches and other programs, moulding a new political orientation among citizens, guided by socialism and self-reliance (Mushi 2009). The pedagogical approaches employed were non-participatory and devoid of critical analysis, allowing the censorship of contradicting perspectives. The definition of a "good citizen" by the independent government 
included the need for all citizens to pledge their commitment and loyalty to the ruling party, the government and key national leaders. In this regard, critical citizenship was associated with the notion of violence, and hence not acceptable in interactions with the state. The delivery channels of civic education included formal political education for the youth in schools and colleges, as well as adult education. There were also public campaigns promoting economic and social development, while radio commentaries (Radio Tanzania Dar es Salaam - RTD) and print media (government and party-owned newspapers, e.g. Uhuru, Mzalendo, Sunday News and Daily News) publicized programs on issues like Ujamaa Vijijini, Mtu ni Afya, and Siasa na Kilimo (Ujamaa, health, science and agriculture). Ultimately, citizenship education cultivated a parochial political culture that enabled the group holding power under the one-party ideology to have maximum control with the minimum conflict (Mallya 2008). All general elections between 1965 and 1990 were held in a single-party system, hence with limited policy alternatives, even when the ruling party did not please citizens. For example, the presidential position had one candidate and the electorates were required to vote YES or NO, with no optional candidate.

Over time, however, international ideas of "development" influenced the internal debates in different ways. For example, throughout the 1970s the development discourse was dominated by the "participatory development model", which focused on the need to involve people in decision making and in the implementation phase. Following the series of global economic disasters $^{1}$ during the late 1970 s, the development discourse from the early 1980s was dominated by Structural Adjustment Programs (SAPs) that embraced a market economy as opposed to one that was state planned. Under the guidance of the Bretton Woods Institutions - the International Monetary Fund (IMF) and the World Bank (WB) - countries in sub-Saharan Africa were pressured to adopt privatization of state-owned enterprises and resources, deregulation and devaluation of currency, reduction of trade barriers, elimination of subsidies in public service provision and the agricultural sector, and principles of good governance and pluralism in politics. However, Tanzania, under the leadership of President Nyerere, was reluctant to subscribe to international development strategies engineered by the Bretton Woods Institutions, rather favouring state-planned strategies (Kiondo 1993). Nyerere was of the view that SAPs were modern imperialist mechanisms of colonization that minimized the ability of the government to organize and regulate its economy in the face of multinational companies. This threatened sovereignty over the economy because international institutions could dictate the nation's economic policy; yet, despite pursuing policies of self-reliance, Tanzania was heavily dependent on international development aid. Therefore, in the late 1980s, the neoliberal agendas of the international community forced Tanzania to reduce the public sector, embrace the market economy and initiate governance reforms in the direction of multiparty politics to address the pressures of democratization. 


\section{Era of reforms and multiparty politics}

After three decades (1960s-1980s) of experimenting with socialism and a policy of self-reliance, Tanzania decided to undertake political and economic liberalization. Political liberalization materialized through the introduction of a multiparty political system and greater space for civil society organizations to function with autonomy from state control. Economic liberalization came through change from a planned economy to a free market economy, which allowed the privatization of state-owned means of production. Politically, Nyerere's post-independence policy had abolished the multiparty political system $^{2}$ which had existed during the pre-independence period. Nyerere's argument was that colonialism was defeated and what lay ahead of every citizen was the fight against the three new enemies of ignorance, poverty and disease. According to Nyerere, the three enemies did not require multiparty politics, hence perpetuating negative images of opposition political parties in order to diminish their public support. The later retreat from the Ujamaa policy came as the outcome of internal and external factors. Internally, President Julius Nyerere and other political activists started to advocate for change from single-party to multiparty political system. Nyerere realized that political pluralism had awarded a victory to the global agenda of democratization, which could no longer be resisted. Meanwhile, the Ujamaa policy had become associated with economic shortcomings and the failure of the state in the field of public service delivery at the end of the 1970s and early 1980s (Mogella \& Kiondo 2006). Consequently, the country adopted a National Economic Survival Programme (1981-1982) and successive SAPs (19821986). Externally, pressure and conditionalities from donor countries, the WB and the IMF made the government implement SAPs, though these reform packages were strongly resisted by Nyerere.

Toward the end of 1980s, Ujamaa lost popularity as a favourite lexicon of development in Tanzania. Instead, vocabularies such as mageuzi ${ }^{3}$ (literally, change or transformation) and utandawazi (globalization) captured the social, economic and political discourses. The new terminologies suggested new duties for the state and corresponding rights among citizens in these fields. In 1992, a multiparty political system was re-introduced through Political Parties Act 1992 (No. 5 of 1992), ending nearly three decades of a single-party system. The newly established opposition political parties took the lead in introducing and promoting the new political language that propagated mageuzi. However, the agenda for changes took place in a context in which the notion of Ujamaa was still alive in the intellectual sphere and diffused across the country by the authorities and ruling party, Chama cha Mapinduzi (CCM), whose stance has remained conservative. Although Tanzania amended its constitution in 1992 to become a multiparty state, the CCM has continued to control the government.

Currently, there are 22 political parties that participate in general elections, which involve the election of the president, members of parliament and ward 
councillors. They also participate in elections for local government authorities to elect village and hamlet chairpersons. To date, Tanzania has conducted five general elections at intervals of five years from 1995 to 2015. All five elections have witnessed a peaceful transition from one government to another, while retaining the leadership of the CCM. The influence of opposition political parties has continued to grow, especially among the few active parties that have representation in the national assembly, including Chama cha Demokrasia na Maendeleo (CHADEMA), the Civic United Front (CUF), the National Convention for Construction and Reform (NCCR) - Mageuzi, and the recently established Alliance for Change and Transparency (ACT Wazalendo). Currently, the national assembly and ward councils are generally dominated by the ruling party with more than 70 per cent of about 390 members of parliament and about 5350 ward councillors respectively (Tume ya Taifa ya Uchaguzi 2016). The rest of the seats are distributed among the opposition parties although the numbers are also affected by the defection of members of parliament and ward councillors from opposition parties to the ruling CCM party.

When the reforms were taking place in the early 1990s, the majority of citizens seemed to be under the influence of the ideas and charismatic leadership of Nyerere and accustomed to the prevalent rule of the CCM at all levels of the society; indeed, there was some resistance to change in the political system. For instance, a public opinion survey reported in the Nyalali Commission Report (1991) indicated that 80 per cent of population had said "no" to the proposed multiparty system (Jamhuri ya Muungano wa Tanzania 1992); ironically, the new political environment necessitated the provision of civic education in order to promote political pluralism (Mallya 2008; Komba $\&$ Ndumbaro 2003). Since the adoption of political liberalization, civic education (at least in theory) has aimed to create well-informed citizens who show their affection for their country by critically examining state institutions. The purpose is to enable citizens to engage and participate actively in critical discussions regarding government policies, structures and actions, in contrast to the historical narratives of the 1960s that carefully framed the past, picking and choosing facts in order to emphasize national unity and peace (Kessler 2006). However, the ideal of a good citizen as a participant in the process of political change rather than the subject of the state is far from being realized.

These reforms have, however, also opened civic space for various interest groups, private sector actors and civil society organizations to play a part in development processes (Mundy 2008). Previously, civil society mobilization, such as women or youth movements, was co-opted by the state into centralized mass organizations. The opening of civic space was accompanied by the mushrooming of civic organizations; in the first decade, for example, the number of registered Civil Society Organizations (CSOs) increased from 224 in 1993 to 8,499 in 2000 (Lange et al. 2000). As part of the structural adjustment package, the plethora of CSO interventions was fuelled by the expansion of donor funding for civil society and NGOs, as donors searched 
for alternative channels through which to support social and political development due to their disappointment in states.

Despite being criticized for working for the people instead of working with the people (Shivji 2007), civil society organizations succeeded in influencing macro level issues such as the democratization agenda, human rights, gender equality and social justice by maintaining public discussion on the issues, and contesting the policies and actions working contra to these principles. Meanwhile, new kinds of civil society organizations provided forums in which people could address their particular challenges at the local level, and a way to acquire potential external financial support for these initiatives. Thus, NGOs and civil society organizations at different levels promoted a variety of ways of perceiving citizenship, and opportunities to "think differently" in terms of, for instance, the state-citizen relationship. Simultaneously, potential donor support created a number of organizations that manifested what Green (2012) calls anticipatory development: continually applying and waiting for donor funding before initiating any activities, resulting in their being conversant with donor policies rather than people's challenges. The priority given to registered organizations has also excluded people without the time or capacity to participate in formal CSO activities (Dill 2009; Mercer 2002).

\section{Contemporary multiparty politics as a context of citizenship}

The contemporary multiparty political system in Tanzania reflects the prior movements and civic associations from which the present parties derive their origin. At the time of the shift from single-party to multiparty politics in 1992, movements and civic associations had not articulated clear political agendas that would have amounted to a struggle to win political power. The new political parties were established on the basis of the ideas of elite individuals, with no clear political ideology, meaning that some political parties only gained strong social support from areas where the founder members originated; this may be compared with the CCM which was supported across the country and had a clearly articulated political ideology. Thus, the drive for a multiparty political system in Tanzania has largely been the outcome of external forces and pressures from the international community rather than internal changes (Mmuya \& Chaligha 1994). Moreover, although not exclusively, political changes have been the product of legislation rather than resulting from the claims of social movements. Thereafter, the established political parties and other elite institutions went on to socialize individuals and the larger society into the new political system. In this respect, while it was expected that the new political system could guarantee a high level of civic activism, the contemporary era still experiences a shortage of social movements.

After the re-introduction of a multiparty system, the ensuing regimes embarked on a project of revitalizing the maendeleo discourse, which is partly born out of the post-socialist situation, characterized by increasing concerns 


\section{2}

Nguyahambi et al.

about economic inequality, threats to national cohesion and the high visibility of corruption in the political sphere (Fouére 2014). Political elites from the ruling party and opposition parties compete in capitalizing on the moral legacy of President Nyerere to build political legitimacy and renew the national consciousness. All political parties claim to advocate social equality and economic justice, prolifically referencing the political principles for which Nyerere stood. However, opposition parties view the ruling party as perpetually striving to impose the state and CCM hegemony on common citizens, while the ruling party claims that opposition parties merely use Nyerere's name to earn popularity, considering itself the only party that should be closely associated with his legacy.

The ability of the government and ruling party to control national discourse has diminished considerably due to presence of opposition parties, the rise of independent media and the role of civil society organizations. However, despite a major overhaul of the civic education curriculum in recent years, the high level of commitment to changing education policy offers evidence of mixed feelings. For example, in 2005 the government banned the operations of HakiElimu ${ }^{4}$ on the grounds that it had presented a "baseless" critique of the government's progress in improving access to primary education (Mongula 2007), which implied the possibility of limiting space for autonomous CSO activity. Recently, the phenomenon of the "shrinking space of civil society" (Civicus 2018) also continues to affect active citizenship in Tanzania. Political pluralism is inhibited by limited freedom of association and restrictions on peaceful demonstrations. The media have remained under strong state control despite expectations that they would be the sounding boards for political concerns, hence hampering the principle of media independence. Freedom of speech is also constrained through various control mechanisms such as social media registration and political party legislation. This has been revealed in the recent public discourse that indicated dissent on the enactment of the Cybercrime Act of 2015, the Media Services Act of 2016, the amendment of the Statistics Act of 2018 (Cap 351) and the Political Party Amendment Act of 2019. Twaweza (2019) asserts that enforcement of those legislations undermines civil society activism, independence of the traditional social movements, freedom of expression in social media, the promotion of human rights, political activism and the autonomy of political parties.

The legal framework for political pluralism formally provides space for multiparty political activities and civil society engagement while the space to claim the rights of excluded groups is de facto limited by social and economic conditions and political constraints (Mallya 2008). Despite restrictions on the claimed spaces, however, development partners provide support for the creation of invited space for dialogue between civil society and local and national authorities. In this way, donor countries, International Governmental Organizations (IGOs) and international CSOs play a significant role in influencing contemporary multiparty politics and the general state of 
the political atmosphere. However, there is some level of laxity on the part of the ruling CCM in adopting the comprehensive practice of liberal policies, taking the conservative stance that unmonitored liberal practices tend to compromise the state of peace and tranquillity that has existed since independence in 1961.

The formal education system provides political socialization through a nation-wide curriculum of Civics (ordinary level secondary schools), General Studies (advanced level secondary schools and colleges) and Development Studies (university). These subjects offer a wide range of topics, including the state and society, and issues of human rights, gender, the environment and globalization (Komba 2013). For adult citizens, learning in the course of participation takes place in different groups that present meaningful spaces; co-operative societies and production groups (Maghimbi 2010), mutual help groups (Rodima-Taylor 2013; 2014) and local savings and loan groups (Green 2019) are all examples of arenas in which people come together and promote their development, while participation in funeral and wedding committees and cultural groups plays a much more significant role than taking part in civil society organizations (Dill 2009). These are all largely autonomous from state control because they do not directly involve a politically related agenda. By taking part in these groups, citizens learn different ways of living in society while fulfilling social and cultural duties and exercising corresponding rights. Political participation, especially in rural areas, refers to taking part in village meetings where joint issues are discussed; however, such participation is passive rather than active engagement in local debate, compared to similar meetings taking place in urban settings which exhibit relatively greater critical reflection.

Political parties also provide citizenship education in order to recruit members and encourage the general population to participate in various political processes, including the general elections. On the other hand, they appear rather to publicize their biased and propagandistic party policies than to present a general agenda for a democratic society (Mallya 2008). Instead of aiming to develop an informed citizenry, political parties use the opportunity to promote their own agendas and attempt to persuade people to vote for them, rather than to exercise their right of individual choice. Meanwhile, since the introduction of political pluralism in the late 1980s, CSOs have also been instrumental in the provision of civic education and promotion of human rights, citizens' agency, democracy and social transformation (Nyang'oro 2006). However, CSOs must operate under strong state monitoring and control and are dependent on their donors' agendas. Their ideal of promoting a vibrant civil society faces the reality that most CSOs are under-resourced, dependent on donor funding, lack democratic leadership and are mostly urban-based. With some longstanding exceptions, they promote issues such as active citizenship, social accountability or democratization only insofar as they receive funding for such programs. Indeed, donors may influence or compel CSOs to shelve their primary objectives, such as facilitating social change, in order to respond to donor funding demands. 


\section{Citizenship in contemporary Tanzania: Contestations and everyday realities}

The legacies of different historical phases can be seen in the contemporary manifestations of citizenship. The initial focus of the nation-building project was the creation of a crosscutting national identity by reducing the legitimacy of sub-group polarization. Despite dismantling the Ujamaa policy and single party politics, people in Tanzania live with the legacy of a political agenda that emphasized nationhood and unity. Consequently, collective debates about citizenship and imaginaries of the nation in contemporary Tanzania continue to be shaped by Ujamaa as a set of moral principles. The images embodied in the figure of President Julius Nyerere have continued to provide an important model for Tanzania's identity and civic values. Most Tanzanians even today refer to Nyerere either as "Mwalimu" (teacher) or as "Baba wa Taifa", the father of the nation, indicating that he is an honoured and benevolent paternal figure and, as such, citizens should be grateful and respect his personality and political principles.

Generally, Nyerere continues to stand as a symbol promoting national unity and criticism of the shortcomings of Ujamaa inside Tanzania is scarce (see Hunter 2008; Schneider 2004). In a similar vein, any open criticism of power holders, or explicit contestations between different political views is not prevalent except for the most vocal, mostly urban-based, civil society activists and opposition politicians. Overall, the on-going democratization, the change from a one-party system to a competitive multiparty system, offers both opportunities and threats to contemporary political citizenship. At the end of the 2010s, the political and legal conditions for political parties and civil society to flourish are deteriorating, although political and civil society activism persists.

Although the state has opened many new avenues to participation, it still strongly resists criticism or public involvement, hence creating tension between state and citizens, CSOs, political parties and media. Remnants of the Ujamaa policy continue to exist, with ordinary citizens displaying fear of the effects of too much political competition. Tanzania has, however, already begun to redefine its national identity for a new era by accommodating new civic virtues in a competitive political culture. The adoption of the latter is happening in a context where political parties and other civic activists continue to pursue peaceful and non-divisive modes of competition, echoing Nyerere's ideas. The fundamental negotiation, at least in rhetoric, is between maintaining a peaceful path and attempting to accommodate a competitive political culture.

The emerging citizenship discourse emphasizes the promotion of democracy, but only to the extent that enjoying civil liberties does not compromise the unity and security of the nation from the point of view of the power holders. For instance, sometimes civic movements, certain forms of political activism and critical individuals are labelled as violent, often facing strong- 
handed reprisal from the state for trading peace and stability for rights. The discourse of maendeleo is also used to de-legitimate critical voices, as anyone not supporting the current path defined by the power holders can be framed as being against development and the good of the country's citizenry as a whole. Moreover, appealing to African particularism and culture is also a means of criticizing "Western democracy" or not acknowledging the full rights of some groups, such as sexual minorities.

\section{Conclusions}

On the basis of our brief overview of the historical evolution and contemporary characteristics of the citizenship environment in Tanzania, we can conclude that ideas and practices of citizenship have been formed through nation building, one-party politics, liberalization and the intertwining of the traces of all these in discourses of maendeleo. The legacy of the nation-building project has created a relatively strong sense of the responsible citizen who participates in development, following the path marked out by paternalistic political leaders: a model strengthened by the merging of party, state and society during socialism, which did not provide much room for manoeuvre for autonomous civil society or individual citizens. While space has gradually expanded as a result of liberalization, there are still tensions in regard to civil society and its opposition today.

The notion that maendeleo hayana chama, wherein the ruling CCM mobilizes support from citizens in order to supply them with development in return, shapes and defines what citizenship is and how it can be practiced in everyday life. Good citizens are those who support government development efforts by being involved in the discourse that promotes peace and national unity. Despite the slow pace of change, the spirit of mageuzi - which differs from that of the Ujamaa era - is flourishing. The new goal is to develop critical minds and participatory citizenship and, indeed, there are many more voices in the political debate with reasoned opinions from different points of view which represent post-liberalization narratives.

Nonetheless, the country faces a great challenge to the practice of democracy because of the limited command of political and citizenship issues and debates among the majority of citizens. The population is predominantly rural dwellers who are not easily reached by social and political activists or civil society organizations. In addition, opposition parties lack good leadership which makes them disorganized often characterized by internal conflicts. Besides, as most party leaders were originally in the ruling party and joined opposition parties after losing their positions, they have neither a clear political agenda nor any desire to institute change. All these elements act as obstacles for the fulfilment of civic duties and the exercise of rights, especially during interaction with state institutions or when citizens try to hold their leaders accountable. 


\section{Box 6.1 Facts about Tanzania}

Population (projection, 2017): 57.3 million

Urban population (2017):33.1\%

Area: $947300 \mathrm{~km}^{2}$

Capital city: Dodoma/Dar es Salaam

Official languages: Kiswahili, English

Governance: Republic, executive president, multiparty system

Literacy rate (2015): $77.9 \%$ (15 years and older)

Life expectancy (at birth) (2018): 66.3 years. Female 68.1 years, Male 64.6 years

Infant mortality (2016): 40.3/1,000 live births

Employment percentage (estimate, 2017): 81.5\% (15 years and older)

Religions: Muslims (appr. 1/3), Christians (appr. 1/3), Traditional and other religions (appr. 1/3).

Ethnical groups: Overall about 120 groups

Human Development Index (2018): Value 0.538 (Rank 154)

Civic space: Repressed

Freedom house indicators (value 100 most free, value 1 most free, 7 least free):

Aggregate freedom score: $45 / 100$

Freedom rating: $4.5 / 7$

Political rights: $4 / 7$

Civil liberties: $5 / 7$

\section{Governance indicators (2017) (100 the highest rank):}

Voice and accountability: $37 / 100$

Political stability and absence of violence: $26 / 100$

Government effectiveness: 28/100

Regulatory quality: $30 / 100$

Rule of law: 35/100

Control of corruption: $39 / 100$

\section{Sources}

CIVICUS (2018). Tanzania. Retrieved from https://monitor.civicus.org/country/tanzania/

The Commonwealth (n.d.). United Republic of Tanzania. Retrieved from http:// thecommonwealth.org/our-member-countries/united-republic-tanzania FAO (2019). United Republic of Tanzania. Food and Agriculture Organization. 
of the United Nations. Retrieved from www.fao.org/countryprofiles/index/en/? iso3=TZA

Freedom House (n.d.). Freedom in the world 2019: Tanzania. Retrieved from https://freedomhouse.org/report/freedom-world/2019/tanzania

UNDP (n.d.). Tanzania (United Republic of): Human development indicators. United Nations Development Programme. Human Development Reports. Retrieved from http://hdr.undp.org/en/countries/profiles/TZA

The World Bank Group (2019). Worldwide governance indicators: Interactive data access. Retrieved from http://info.worldbank.org/governance/wgi/index. aspx\#reports

\section{Notes}

1 Economies in many countries across sub-Saharan Africa experienced economic glitches such as oil and debt crises and multiple economic depressions, leading policy makers to decide that deeper intervention was necessary to improve a country's overall well-being.

2 Tanganyika had a multiparty political system before attaining independence in 1961. The parties included the Tanganyika African National Union (TANU), the African National Congress (ANC), the United Tanganyika Party (UTP) and the All Muslim National Union of Tanganyika (AMNUT). However, soon after independence, Mwalimu Nyerere, who was TANU chairman and the first president of Tanganyika, announced a single party political system in 1962 and banned other political parties although they had all struggled for independence. Hence, a Single Party Constitution was introduced in 1965; TANU became the only party and all citizens joined it.

3 Mageuzi reflected political and economic liberalization, a critical turn from a single party to a multiparty system, and from socialism to a free market economy.

4 HakiElimu is a civil society organization that strives to transform education, in and out of schools, and to influence policy making and its effective implementation, while stimulating imaginative dialogue and social change.

\section{References}

Alava, H., Bananuka, T.H., Ahimbisibwe, K.F. \& Kontinen, T. (2019). Contextualizing citizenship in Uganda. In this volume.

Aminzade, R. (2013). Race, nation and citizenship in post-colonial Africa: The case of Tanzania. New York: Cambridge University Press.

Bakari, M. \& Ndumbaro, L. (2001, November). Religious and governance in the post-liberalization era. Paper presented at the Conference on Religious and Politics. Research and Education for Democracy in Tanzania (REDET). Dar es Salaam, Tanzania.

CIVICUS (2018). State of civil society report 2018. Retrieved from CIVICUS Monitorwww.civicus.org/documents/reports-and-publications/SOCS/2018/socs-2018-over view_top-ten-trends.pdf

Dill, B. (2009). The paradoxes of community participation in Dar es Salaam. Development and Change, 40(4), 717-743.

Fouéré, M.-A. (2014). Julius Nyerere, Ujamaa, and political morality in contemporary Tanzania. African Studies Review, 57(1), 1-24. 
Green, M. (2012). Anticipatory development: Mobilizing civil society in Tanzania. Critique of Anthropology, 32(3), 309-333.

Green, M. (2019). Scripting development through formalization: Accounting for the diffusion of village savings and loans associations in Tanzania. Journal of the Royal Anthropological Institute, 25(1), 103-122.

Holma, K. \& Kontinen, T. (2019). Practices and habits of citizenship and learning. In this volume.

Hunter, E. (2008). Revisiting Ujamaa: Political legitimacy and the construction of community in post-colonial Tanzania. Journal of Eastern African Studies, 2(3), 471-485.

Hyden, G. (1981). Beyond Ujamaa. In B. Mwansasu \& C. Pratt (Eds.). Towards socialism in Tanzania. Buffalo, NY: University of Toronto Press.

Jamhuri ya Muungano wa Tanzania (1992). Tume ya Rais ya Mfumo wa chama Kimoja au Vyama Vingi ya Siasa Tanzania, 1991 (Nyalali Report, Vol. 1-3). Dares-Salaam: Government Printer.

Jennings, M. (2017, September). Ujamaa. Oxford Research Encyclopaedia of Africa History. Retrieved from DOI: doi:10.1093/acrefore/9780190277734.013.172

Kessler, I.R. (2006). What went right in Tanzania: How nation building and political culture have produced forty four years of peace (Unpublished thesis). Edmund A. Walsh School of Foreign Services of Georgetown University, US.

Kiondo, K.S. (1993). Structural adjustment and non-governmental adjustments in Tanzania: A case study. In P. Gibbon (Ed.). Social change and economic reform in Africa (pp. 161-183). Uppsala: The Scandinavian Institute of African Studies.

Komba, W.L.M. (1996). Changing politics and political culture in Tanzania: The impact on political education and civics curricula, 1967-1994 (Doctoral dissertation, University of London Institute of Education, London). Retrieved from https://core. ac.uk/download/pdf/33676995.pdf

Komba, W.L.M. (2013). Citizens' views on appropriate civic education curricula under multiparty democracy in mainland Tanzania. Journal of Education and Practice, 4(3), $27-37$.

Komba, W.L.M. \& Ndumbaro, L. (2003). Towards a coordinated national civic education strategy in Tanzania. Journal of the Faculty of Education, University of Dar es Salaam, 23, 147-167.

Lange, S., Wallevik, H. \& Kiondo, A. (2000). Civil society in Tanzania (CMI Report R 2000:6). Bergen: Chr. Michelsen Institute, Development Studies and Human Rights.

Lawson, A. \& Rakner, L. (2005). Understanding patterns of accountability in Tanzania. Oxford: Oxford Policy Management. Retrieved from www.gsdrc.org/docs/open/ doc98.pdf

Liviga, A. \& Tumbo-Masabo, Z. (2006). Muslims in Tanzania: Quest for an equal footing. In R.S. Mukandala, S. Othman, S. Mushi \& L. Ndumbaro (Eds.). Justice, rights and worship- religion and politics in Tanzania (pp. 129-164). Dar es Salaam: University of Dar es Salaam, REDET Department of Political Science and Public Administration.

Maghimbi, S. (2010). Cooperatives in Tanzania mainland: Revival and growth (Cooperative Development in Africa Working Paper No. 14). Retrieved from www.ilo. org/public/english/employment/ent/coop/africa/download/wpno14cooperativesinta nzania.pdf

Mallya, E. (2008). Civic education in Tanzania: An assessment. Research and Education for Democracy in Tanzania (REDET). Retrieved from www.academia.edu/ 12987169/CIVIC_EDUCATION_IN_TANZANIA_AN_ASSESSMENT 
Mercer, C. (2002). The discourse of maendeleo and the politics of women's participation in Mount Kilimanjaro. Development and Change, 33(1), 101-127.

Miguel, E. (2004). Tribe or nation? Nation building and public goods in Kenya versus Tanzania. World Politics, 56(3), 327-362.

Mmuya, M. \& Chaligha, A. (1994). Political parties and democracy in Tanzania. Dar es Salaam: Dar Es Salaam University Press.

Mogella, C. \& Kiondo, A. (2006). Historical development of the civil society in Tanzania. In A.S. Kiondo \& J. Nyang'oro (Eds.). Civil society and democratic development in Tanzania (pp. 19-32). Harare: Mwengo.

Mongula, B. (2007). State-civil society relationship: The case of the state and HakiElimu in Tanzania. Tanzania Journal of Development Studies, 7(1), 1-15.

Mpangala, G. (1992). Major issues in Tanzanian economic history: Pre-colonial economy and social formations. Dar es Salaam: Dar es Salaam University Press.

Mundy, K. (2008). From NGOs to CSOs: Social citizenship, civil society and "Education for All". Current Issues in Comparative Education, 10(1/2), 32-40.

Mushi, P.A.K. (2009). History and development of education in Tanzania. Dar es Salaam: University of Dar es Salaam Press.

Nyang'oro, J. (2006). Civil society and political development in Tanzania: An introduction. In A.S. Kiondo \& J.E. Nyang'oro (Eds.). Civil society, democratic governance and political development in Tanzania (pp. 8-18). Harare: Mwengo.

Nyerere, J.K. (1962). TANU na Raia, Julius K. Nyerere, Rais wa TANU. Dar es Salaam: Tanganyika National African Union.

Nyerere, J.K. (1968). Ujamaa: Essays on socialism. Dar es Salaam: Oxford University Press.

Pratt, C. (1981). Tanzania's transition to socialism: Reflections of a democratic socialist. In B. Mwansasu \& C. Pratt (Eds.). Towards socialism in Tanzania (pp. 193236). Buffalo, NY: University of Toronto Press.

Rodima-Taylor, D. (2013). Gathering up mutual help: Relational freedom of Tanzanian market-women. Social Analysis, 57(3), 76-94.

Rodima-Taylor, D. (2014). Passageways of cooperation: Mutuality in post-socialist Tanzania. Africa, 84(4), 553-575.

Rwengabo, S. (2016, August). Nation building in Africa: Lessons from Tanzania and South Sudan. Paper presented at Mandela Institute for Development Studies (MINDS) Youth Dialogue. Dar es Salaam, Tanzania.

Schneider, L. (2004). Freedom and unfreedom in rural development: Julius Nyerere, Ujamaa Vijijini, and villagization. Canadian Journal of African Studies/Revue canadienne des études africaines, 38(2), 344-392.

Schneider, L. (2006). Colonial legacies and postcolonial authoritarianism in Tanzania: Connects and disconnects. African Studies Review, 49(1), 93-118.

Shivji, I.G. (2007). Silences in NGO discourse: The role and future of NGOs in Africa. Oxford: Fahamu.

Stöger-Eising, V. (2000). Ujamaa revisited: Indigenous and European influences in Nyerere's social and political thought. Africa, 70(1), 118-143.

Tume ya Taifa ya Uchaguzi (2016). Taarifa ya Tume ya Taifa ya Uchaguzi Kuhusu Uchaguzi wa Rais, Wabunge na Madiwani, 2015. Dar es Salaam: Tume ya Taifa ya Uchaguzi.

Twaweza (2019, January 28). The statement on proposed amendments to the Political Parties Act (2002). Twaweza. Retrieved from www.twaweza.org/index.php?i=1739 


\title{
7 The everyday and spectacle of subdued citizenship in northern Uganda
}

\author{
Henni Alava
}

\section{Introduction}

How does it feel to be a citizen? This chapter draws attention to the observation that every citizen is a body which exists in the world in a particular place and time. In this vein, it builds on the contention that citizenship is not just a static status, but something that is done - actively or passively, consciously or unconsciously, willingly or reluctantly - but always by a body. Understanding how citizenship feels and has historically felt is thus a crucial aspect of understanding citizenship in any given context. Drawing on ethnographic research in the Acholi region of northern Uganda, I demonstrate how citizenship practices are embedded in particular relationships between the state and its citizens. Employing aspects of Achille Mbembe's theory of postcolonial statehood, the chapter highlights the role of everyday violence and spectacular political performances in citizenship practices in contemporary Uganda.

From 1986, when the rebel forces of the incumbent president, Yoweri Museveni, took over Kampala, until 2006, the Acholi region was ravaged by warfare between the Lord's Resistance Movement/Army (LRM/A) rebels and the Ugandan state. During the latter years of the northern Ugandan war, and in the few years of intense post-war reconstruction that followed, the Acholi region was the target of massive humanitarian and development intervention. Much of this intervention espoused, at least on paper, a "rights-based" approach, and has included so-called "civic education" activities. The rhetoric and jargon of active citizenship, democracy, human rights, participation, empowerment and so on, are thus well-known in the region, both to the former participants and even more so to the former employees of such projects. As I show, however, there is a disheartening gap between the benign rhetoric and the malign practice of state-citizen relations in Uganda. Decades of violent encounters with the state, and experiences of not being protected by the state, have led many of the Acholi people living in this region to embody what I refer to as subdued citizenship. In contrast to the informed, active and engaged citizens envisioned by theories of "good citizenship", subdued citizens engage in the body politic on the basis of uncertainty and misinformation and relate to the state primarily through submission or aversion. 
My analysis draws from altogether ten months of ethnographic fieldwork that I conducted primarily in Kitgum town, between the years 2012 and 2016. The analysis that I unfold in this chapter draws from over a hundred formal interviews, media and other secondary sources, and detailed ethnographic fieldnotes of religious and political events and formal and informal gatherings. The focus of the research project was on the role of the Catholic and Protestant (Anglican) Church in the re-imagining of society and politics in the aftermath of war (Alava 2017b). In this chapter, I elaborate on arguments I have developed in greater empirical detail elsewhere (see ibid.), with a particular eye to the question of citizenship.

After outlining a theoretical approach to the chapter's analysis, I sketch an overview of the recent history of state-citizen relations in northern Uganda. Thereafter, I turn to ethnographic evidence to argue that the everyday in the Acholi region is tinged by silence and fear pertaining both to the violence of the past and to the uncertainty and fears of violence in the present. The spectacular moments of state performance that take place, and that are interpreted in the midst of this everyday, include presidential visits to church celebrations, one of which I use to illustrate my argument. I conclude by returning to reflect on the question of how and where citizenship is learned and consider the prospects for growth into citizenship in a context profoundly imbued with violence.

\section{Citizenship and state violence}

Grasping what citizenship means in northern Uganda - and arguably, in all former colonies - requires the recognition of violence as one of the constitutive elements of the relationship between states and citizens. As a lineage of scholars since Fanon (1967) has argued, this violence has its roots in the violence of colonialism, which left its marks not only on the structures and trappings of the state, but in the minds and bodies of its citizens. Writing of China, Kleinman and Kleinman observe:

Bodies transformed by political processes not only represent those processes, they experience them as the lived memory of transformed worlds. The experience is of memory processes sedimented in gait, posture, movement, and all the other corporal components which together realize cultural code and social dynamics in everyday practices.

$(1994,716-717)$

For Achille Mbembe, the relationship between rulers and subjects (dubbed states and citizens in independence constitutions) - is "inscribed in a largely shared symbolic order" (Mbembe 2006, 159). Violence and destruction, alongside possession and enjoyment, are foundational for this order. Yet because the symbolic order is shared, violence and destruction need not simply be impressed upon subjects by their rulers: the subjects of power 
themselves participate in creating and upholding the regime to which they are subjected. In Judith Butler's rephrasing: "power compels its subjects ritualistically to perform, within and through the mundane practices of civil society, a ratification of its own spectacular excess" (Butler 1992, 68).

Yet in Mbembe's analysis there is a double nature to the events and practices whereby citizens ratify the state - a duality through which the overwhelming power of the state may at times be called to question:

This very process of ratification becomes itself the site for a subtle delegitimation of state power. The paradox is that this subtle process takes place through the very authorizing or ratifying rituals... [T] his kind of deauthorizing subversion which takes place in and through the exercise of ratification re-authorizes that power at the same time that it exposes its vulnerability.

(Mbembe 2006, 161)

Although Mbembe acknowledges the potential for citizens to destabilize the violent excess of state power through their participation, the overall tone of his analysis remains bleak. One among the critics to point this out is Mikael Karlström, who, drawing from ethnographic research of political ceremonies in Buganda, argues that whereas Mbembe depicts the ceremonial patterns of power as intrinsically pathological, Karlström's own analysis suggests that these ceremonies may in fact provide "resources for popular critical consciousness" (2003). In part, these different interpretations are dependent on the regionally and temporally specific relationships between the state and its citizens. In some places more than others, the state forces citizens into submission to the degree that little or no space for critical consciousness remains.

\section{Legacies of state violence in northern Uganda}

The northern Ugandan war is commonly portrayed as a "rebel war by the Lord's Resistance Army", or as an internal conflict between the LRA and the Ugandan government. However, over the years, the war became deeply embroiled in relations of power and money that far exceeded the local arena: proxy warfare between Sudan and Uganda (Prunier 2004); the plunder and global trade of natural resources (Zeller 2013); attempts to protect Uganda's role as a "golden boy" of the international aid regime (Mwenda 2010); the US-led "war against terror" (Branch 2012); the selfdefeating practices of humanitarian assistance (Finnström 2012); and battles waged in the field of international criminal justice (Branch 2007). Amidst such global "shadows of war" (Nordstrom 2004), Acholi citizens had very little scope for influencing the trajectories of their lives - something of which they were painfully aware (Finnström 2006). Central to this sense of abjection was the fact that civilians suffered at the hands of both 
the LRM/A rebels and the Ugandan army - often on account of one party's suspicion that civilians were supporting the other.

The Lord's Resistance Army and its predecessors launched their rebellion in 1986, as a response to violence meted out against the Acholi people in the wake of the capture of state power by incumbent president Yoweri Museveni (see, for instance, Atkinson 2010; Finnström 2009). Whereas in many other parts of the country Museveni was hailed as a saviour who ended the violent chaos of the preceding decades; for the Acholi, who had previously held prominent positions in the government and army, there was much to fear in Museveni's ascent to power. The profound distrust felt by many Acholi towards Museveni's regime deepened during the northern Ugandan war. Not only did the state force people into internal displacement in squalid conditions, many for a whole two decades, the military also meted out harsh violence against civilians. Museveni was also accused of deliberately perpetuating the war because it was so enormously profitable for a small military elite, and in order to justify military expenditure to the country's international donors. The outcomes of the war for Acholi citizens were terrifying.

Chris Dolan has described the situation of Acholi citizens during the war as one of social torture. What distinguishes social torture from individual torture is that it takes place over long periods of time across a vast geographic area and takes the form of violence, intimidation, sexual abuse (see also Porter 2016) and humiliation that targets an entire community or society. Social torture is perpetrated by multiple actors and is justified to a broader society through the application of tailored public discourses (Dolan 2009, 12). Dolan argues that the northern Ugandan war was particularly traumatising for many Acholi because the very entity that was supposedly responsible for protecting its citizens - the state - was itself culpable for much of their suffering.

The war was an outgrowth of a long history of violence in the region. The Acholi suffered tremendously under Idi Amin's reign, and British colonization in this region was brutally violent, as were the slave and cattle raids that preceded it. Yet the overwhelming majority of the Acholi population is too young to have personal memories of the time before Museveni; it is thus primarily against the backdrop of the National Resistance Movement (NRM) regime that relationships between the state and its citizens are crafted in northern Uganda. Of note is that my latest visit to northern Uganda in 2016, from which the second of my ethnographic examples below draws, coincided with a presidential election. As during earlier elections, this was a time of heightened political awareness, rumours, and fear; my analysis is thereby particularly tuned in to aspects of the "sense of citizenship" that, had I conducted my fieldwork in less strained times, may have gained less prominence. Yet I argue that the points I make have more general validity. For instance, the heightening of Museveni's anti-opposition measures in recent years bears witness to the relevance of my analysis for a general understanding of citizenship in Uganda. 


\section{Learning citizenship in the everyday: Memories, rumours, fear}

In February 2015, Kitgum town was busy preparing for the arrival of President Yoweri Museveni as the guest of honour at two different church events: the centenary celebration of Kitgum Catholic Mission, and the national commemoration of Saint Janani Luwum, an Anglican bishop killed by Idi Amin for his opposition to the violence of Amin's regime. In the midst of preparations, a rumour circulated in town that "some people" some claimed them to be "men from [the capital city] Kampala" - had been inciting people to insurgency in a remote village in Eastern Acholi. As the rumour had it, numerous army trucks had appeared, and people had been forced to burn their own huts and the surrounding bush so that the soldiers could search for weapons allegedly hidden by the purported rebels. There was no reference to such events in the national media, and the various people who mentioned the rumour to me all insisted it had come to them through acquaintances with relatives or friends living in the affected area. The details in the story were somewhat vague, which was not surprising. As one man put it when I asked him for more details, "Here, it is hard to know what is actually happening."

While there was no way for me to verify whether the rumour was grounded in fact, what is noteworthy is that the villains of the piece were not the purported rebel group but, rather, the government soldiers who came to bully the locals and force them to burn their huts. As such, the rumour resonated more with people's memories of the government's anti-insurgency activities during the war than with the violence perpetrated by the LRM/A (see Atkinson 2010; Branch 2003; 2011; Dolan 2009; Finnström 2009). It was thus not a coincidence that the timing of the rumours coincided with the president's arrival. Rather, having soldiers en masse in Kitgum to "secure the town" for Museveni's visit, as my friend described their presence, reactivated memories of a commonly experienced but silenced past of state violence, and led them to spill over as rumours in the present.

In Kitgum, memories of the past co-mingled with contemporary political events, and the ubiquitous rumours attached to them. The way in which these were discussed, or silenced, in the midst of everyday encounters, reflected how people considered their engagements with the state. For instance, sometime after the death of a vocally critical young NRM MP, Cerinah Nebanda (see Alava 2017b, chapter 7 for more details), I asked two people with whom I was eating whether there had been much talk among their acquaintances about the matter. One of them fell quiet, drank his water and left without saying a word. After a while, the man remaining said, "People are learning not to comment." I sighed and said that things did not sound good, to which he replied, "Yes. These things are happening. And they're going to keep happening. Uganda is moving towards totalitarianism." After a moment's silence, he sang the first lines of the Ugandan national anthem's second verse: 
Oh Uganda! The land of freedom,

our love and labour we give.

And with neighbours all

at our country's call

in peace and friendship we'll live.

In the context of a nation buzzing with rumours about a purported political murder, the irony of the anthem's words could hardly have been more glaring. For many, perhaps particularly in the context of the churches I studied, "Oh Uganda" resounded more as a prayerful lament, rather than as praise. From the perspectives of many of my acquaintances in Kitgum, Uganda was not a land of freedom, nor one of peace and friendship. In addition to the experiences of war, which had cast their shadow on the anthem's glowing portrait of the nation, the image was further tarnished by rumours of deaths like Nebanda's, and by the fears that percolated through everyday lives, none of which lent credence to the notion of Uganda as a land of freedom.

Among the most often-cited of such fears were rumours that the government had spies keeping an eye on anti-government talk and activities in every village, every local council, every workplace and every church (see Alava \& Ssentongo 2016), although people practically never spoke of the stories as rumours, but as facts. These reports intensified at certain times: in 2015, for instance, as the country began to prepare for the 2016 elections, when my friend Orom explained the unlikelihood of Museveni losing in the following way:

You know here, there is a system already in place, everywhere. The state intelligence has officers all over, even in this village here, they are there. I could be a security officer, and you would never know. Or you could be, and none of us would ever know.

"Even here?" I asked, pointing to the serene scenery of houses and fields through which we were walking. "Yes," Orom answered with a serious look on his face. "If you start talking too much against the government, they will report you, and one day the army will come to your door, and you will be taken away. And never be seen again." While recent, documented cases, other than those of prominent politicians like Cerenah Nebanda, were seldom referenced as reasons for such fears by my interlocutors, Cecilie Lanken Verma's longitudinal study spanning a number of years during which she followed the lives of former LRM/A rebels who were retrained and recruited as so-called "NRM cadres", suggests that Orom's fears were not unfounded. Rather, she writes: 
I no longer doubt the very dense presence of spies and government agents scattered over even the vast peripheries of Acholiland - possibly the whole country - in the name of internal and external state security and in the form of a range of different networks and cells to which you can belong as different ranks or categories of informers. That makes for a constant flow of - and a constant suspicion of - information and questions that are considered a matter of or as scrutinizing "politics" and "security".

(Verma 2013, 48)

As noted by Rebecca Tapscott, who has recently conducted research on nonstate security provision in Acholi, there has been speculation as to the actual capacity of such local-level security initiatives and possible spy networks (Tapscott 2017). However, I would argue that from the perspective of Kitgum, and my informants, none of whom as far as I ever learned were themselves involved in such networks, the question of how efficient state security networks actually are, was somewhat irrelevant. Rather, the crucial issue seems to be that in part due to previous experiences of state violence, many people in Acholi believe state security to be extremely and dangerously effective; they believe the state to have, as one of Tapscott's (2017) informants put it, such "long hands", that were they to take up any kind of anti-government activities, the information would quickly reach the ears of the state, with grave repercussions. As Finnström has noted, experiences of violence result in the very real and at times realized "fear of the midnight knock" (2009) by state officials or unidentified assailants presumed supported by the state.

The sense of unsettledness that the rumours provoked in my friends also found its way under my own skin. For instance, when my Internet stopped working on the same day as the soldiers rolled into town prior to Museveni's visit, I became fairly convinced that the malfunction was due to the arrival of powerful tracking devices to spy on internet activity and phone calls in the area. Although I logically surmised that I was probably overreacting, the nagging sense of uncertainty was unsettling, and the fear that the incident retriggered (a fear I had often experienced earlier during the fieldwork) lingered even once the Internet problems were pinpointed as my modem's being outdated. Often, I was fairly sure that much of what I was doing and saying was being reported "somewhere", by someone perhaps even close to me. But the key point to make here is not my own experience, but how my own experience attuned me to understanding that I was not alone with my suspicions, fear and unsettledness - they were sensations I was picking up from, and coming to share with, those around me.

As Meinert has written, in post-war Acholi, "the trick [is] to expect distrust, and then possibly, and carefully, to unfold a sense of trust over time; trust which might, however, later revert to distrust" $(2015,126)$. My own sensations reflected the ambivalences, suspicions, and feelings of not-reallyknowing that colour people's sense of politics in Acholi. This sense is 
foundational for the way in which citizenship is experienced and practiced in this context. The everyday learning processes through which a particular sense of citizenship becomes engrained within Acholi citizens is complemented in moments of extraordinary state presence, what Mbembe calls the carnivals of the postcolonial state. It is to one such carnivalesque moment of citizenship learning that I now turn.

\section{Learning citizenship at the spectacle: Presidential visits at church celebrations}

At the church events which brought Museveni to Kitgum in 2015, the playing field was completely cleared in the president's favour, and no speakers representing the political opposition were allowed onto the podium. The many speeches that preceded the president's address were either utterly apolitical, or sang his praises. Museveni was thus free to craft his speech as he saw fit. The longest segments in Museveni's speeches at the events focused on reprimanding the Acholi. To this end, he employed a gimmick he regularly uses while travelling around the country, that is, he emphasized his key point through the application of a few select words in the local language. At the handover of the Mission in Kitgum, these words were lotuko (players) and loneno (spectators):

For football, you need both... But when you have got lotuko and loneno in the economy, that's a big problem. According to the 2002 Census, it showed that 32 of homesteads were lotuko: they were in the money economy. Sixty-eight percent were loneno. They were just spectating.

At Luwum's commemoration on the following day, Museveni developed the argument further. He mentioned that the previous day someone had complained to him that the problem in Acholi - the reason why they are not lotuko - was that people are poor, but, the president insisted:

You cannot be poor if you have land. The problem isn't poverty, the problem is sleeping. Archbishop Sentamu [a Ugandan cleric currently serving as the Bishop of York, who officiated at the service] can tell you how many people there are in the UK with as many acres of land as you. Poverty is not the problem but sleeping. People must now all be lotuko.

To make sense of the weight of Museveni's claims, they need to be analysed in the context of the political economy of northern Uganda. As mentioned in the contextualising chapter on Uganda, a significant politico-economic divide has cut across northern and southern/central Uganda since colonial times. To this day, almost a decade after the end of war in northern Uganda, the income disparity between the north and the rest of the country remains conspicuous (UNDP 2015, 21). Many of the Acholi lost practically everything 
they owned due to the war. Most notable among their losses, both economically and psychologically, was the loss of their cattle, which were of crucial importance to them: as capital, for tilling the soil, for manure and for forging social cohesion and security through bride price (Alava 2017a). Alongside the loss of cattle, people in the region have undergone years of physical and psychological torment in a war in which Museveni was far from innocent (Branch 2011; Dolan 2009). In consequence of these factors the majority of the Acholi continue to exist on low-technology subsistence agriculture (UBOS 2014). There are many reasons for the scarcity of higher-intensity agriculture and the low level of manufacturing industries in the region, such as unclear land tenure, low-yielding soils, lack of access to external markets (Gollin 2010), and limited access to credit - none of which were mentioned by Museveni in his speech. Arguably, many of these are issues that the government could have influenced to a greater extent than it has; for instance, the most recent agricultural census conducted in Uganda showed that only 6.2 per cent of northern Ugandan farming households had access to credit, in comparison to 14.4 per cent of those in President Museveni's home region of Western Uganda (UBOS 2010).

Museveni concluded his speech by announcing that because so much of the money he had so far sent to the north had been devoured by what he called "clever people", he had decided he would no longer allow civil servants to run development projects in the region (for an analysis of the extensive corruption of "recovery" initiatives in the region, see Golooba-Mutebi \& Hickey 2010). Instead, from now on, special army officers would distribute building materials and farm inputs in what was called "Operation Wealth Creation". Two things stand out in the announcement. First of all, building materials and farm inputs do not go far towards solving the bigger issues of political economy that drive people into subsistence agriculture and maintain high levels of poverty in northern Uganda. Secondly, with this announcement, Museveni narrated himself into the role of the benefactor, placing all the blame for the appropriation of northern Uganda's billions of shillings of aid money on people below him, while simultaneously circumventing claims that the army itself might be corrupt (see Mwenda \& Tangri 2013).

In light of all this it seemed there were good reasons for people to be angered by the president's words, and to express their anger. But no-one did. In contrast to the mass annoyance I witnessed at an event I had attended three years earlier (see Alava 2017b, chapter 6) there were no rebuking sounds of "tst-tst" or shouts of "goppa!" (lies!) directed at Museveni, nor gleeful ululations at the opposition's subtle ridiculing of him - just unbroken silence and thousands of eyes staring either at the ground or in the president's direction. How was it that the audience seemed to accept Museveni's berating without the slightest indication of protest?

To answer this question, we must observe that the President's speeches were not novel, but, rather, drew from a well-rehearsed repertoire of anti-Acholi sentiments. In particular, they resonated with the official discourse by which 
Museveni has internalized the problems of northern Uganda into Acholi throughout the past three decades (Alava 2008). This builds upon racist colonial representations of the Acholi people as essentially warlike and unpredictable and, particularly since the war, as both lazy and shackled by dependency syndrome (Finnström 2008). The speeches were thus a continuation of a dynamic that was evident throughout the northern Ugandan war. State rituals like this one figuratively and literally guide Acholi bodies towards submission. While this submission is at times reversed (see Alava $2017 \mathrm{~b}$ for examples), overall, a submissive habitus has been engrained among many Acholi over the past decades of war and "post-war". Following Mbembe (1992), this submission cannot be seen simply as a case of coercion and lack of opposition; rather,

[i]n the postcolony, an intimate tyranny links the rulers with the ruled, just as ... vulgarity [is] the very condition of state power. If subjection appears more intense than it might be, it is also because the subjects of the commandement have internalized the authoritarian epistemology to the point where they reproduce it themselves in ... daily life.

(Mbembe 1992, 22-23)

Internalization of the authoritarian epistemology takes place within a system of oppression wherein the oppressed "adopt an attitude of 'adhesion' to the oppressor" (Freire 1968/1990, 45 quotation marks in original). As Freire explains, this adhesion "does not necessarily mean that the oppressed are unaware that they are downtrodden, [b]ut their perception of themselves as oppressed is impaired by their submersion in the reality of oppression" (ibid.). Freire's analysis of oppression illuminates the role-play witnessed at the lotuko event I described above, where the president takes on the role of benefactor, and convinces the audience that, due to their inadequacy, his benefaction is what they need (ibid., 49-54).

Self-depreciation is another characteristic of the oppressed, which derives from their internalization of the opinion the oppressors hold of them. So often do they hear that they are good for nothing, know nothing and are incapable of learning anything - that they are sick, lazy, and unproductive - that in the end they become convinced of their own unfitness (Freire 1968/1990, 63).

Freire's description is almost eerily prescient in light of the case I have presented - as if Museveni has read the "Pedagogy of the Oppressed" as an oppressor's guidebook. A profound indication of the humiliation intrinsic to such internalization was provided at the handover of the Catholic Mission in Kitgum, where the chairperson of the District Council (LC5) thanked the president for a cattle-restocking program in which 798 cows had been given to farmers in the district as compensation for those lost to cattle rustlers in previous decades. I quietly asked a friend sitting beside me how many cows his family had lost in the raids, which many people in the area believe were silently condoned if not orchestrated by Museveni to snap the backbone of 
the Acholi. He answered, "Three hundred." Yet the chairperson of the district humbly thanked the president for 798 head of cattle. ${ }^{1}$

In discussions about the relationship between the Acholi and Museveni's state, expressions such as "we have been forgotten" or "we don't exist" are commonly used. The most concise and harsh of such statements that I heard during my fieldwork was made by a well-educated Catholic man in his forties, Komarach, who described the state's attitude to the Acholi thus: "We are like condoms; we're used and thrown away." Komarach's likening of the Acholi to condoms which, as he explained, are used for pleasure but get no part in it themselves, poignantly illustrates the intensity and intimacy with which the relationship with the state is experienced in post-conflict northern Uganda, as well as the sense of humiliation that colours it.

In sum, the lack of expressed annoyance by the crowd listening to Museveni's speech can be read as a result of the submissive habitus tinged with humiliation and shame that many in the region have adopted in relation to the central state. Mbembe holds that the postcolonial bodies which submit to playing the part of the submissive citizen cheering the state do so "precisely in order to better "play' with it and modify it whenever possible" (1992, 22-23). A Mbembeian interpretation of the events - of the large numbers of people who crowded to take part, of the excitement that the events engendered among spectators, and of the laughter sometimes witnessed at similar events in response to opposition leader's inciting and insightful speeches - might suggest carnivalesque enjoyment as a central aspect of public church events and of the performances of statehood seen therein. At the events attended by Museveni in 2015, however, there was none of the playful mockery of the state apparatus that Mbembe describes. Neither did I see such play in the weeks after the clampdown on opposition protests in 2016; nor in the submissive silences into which many retreated as soon as the politics of the state - the army, or state security officials - were raised in discussion. From this it appears that the ludic resources available to the subjects of the postcolonial state are more available for some than they are for others, and at some moments than at others. In contemporary post-war Acholi, these resources are limited by the vulgar and obscene violence of postcolonial performance (Mbembe 1992, 29-30) coupled with the less symbolic and more direct violence of the gun. Indeed, Museveni's transfer of "development initiatives" to the army gave him the perfect reason to deploy the military to rural areas (Vokes \& Wilkins 2016, 592). At times of heightened security in particular, such as in the run-up to elections, there is very little space in Acholi for the kind of laughter Mbembe claims to be subversive. When faced with the inevitability of a gun, that laughter dies.

This threat had practical implications for the rationales by which people judge politics. Even though there seemed to be no immediate threat of violent retaliation were people to stand up and protest, one could not be sure. Opposing the president might turn him even more firmly against the Acholi, hence, rather than rallying in anger, it was better to respond with silence. 


\section{Discussion: How does it feel to be a citizen in Acholi?}

So far, I have argued that in the Acholi region, the violent core of the NRM state inserts itself into the private realm of people's homes, lives and thoughts, so that even in the absence of overt state repression, and in the intervals between the state's public appearances, an under-the-skin sense of the state prompts people into submission. This cautious habitus is the outcome not only of the sense of an external and potentially violent state, but also of often war-related tensions and divisions among the Acholi, which are pressed underfoot and veiled in silence (see Alava 2017b).

Such circumstances have significant impact on the possibilities for ideal, benign citizenship to emerge. In Mbembe's $(1992 ; 2001)$ view, postcolonial citizenship is in part practiced through the employment of ludic resources which citizens can use to challenge and even ridicule the champions of state power. Such ludic resources, however, are constrained in Acholi, where many are persuaded as a result of pragmatic political calculation to adopt a variant of the subjunctive mood (Whyte 2002; 2005) as the cornerstone of their engagements with the Ugandan state. Judging by the analysis of one discouraged former Anglican bishop, Zac Niringiye, the predicament of statecitizen relations in Acholi is not the predicament of northern Uganda alone. He writes:

We must lament the failure of citizenship in Uganda. While the immediate casualty of corrupt and un-accountable leadership is service delivery, the long-term impact is on citizenship. Patronage kills citizenship; citizens are turned into subjects, both the assertion of rights and the exercise of responsibility die. Hence the current state of Ugandan citizenry: fear, apathy and slumber

(Niringiye 2017, 254).

In Niringiye's analysis, the blame is laid principally on the NRM regime; he claims, however, that the results of practiced statehood bleed over time into the realm of the citizen, and that the citizenry can choose how to respond to this bleeding. In Uganda, Niringiye claims, citizens have failed.

[O]ver time Ugandans have surrendered their rights and reneged their responsibilities... Ugandan voters have chosen inducements from the Museveni regime at election time and shied away from harassment that comes with opposition. Citizen organisations have either been killed, such as cooperative societies, or weakened and replaced with patronage networks.

(Niringiye 2017, 255)

Reflecting on Niringiye's words, one can debate whether there is any possibility for citizens or citizens' organizations to respond in anything other than 
subdued ways. What I claim is that the primarily submissive habitus that Acholi citizens have adopted towards the state is adopted on the basis of a pragmatic political calculus. In light of the history of state violence in the region, and the prevalence of on-going state-perpetrated violence, or rumours of it, one can rightly argue that submissive citizenship - "voluntarily" bowing down to the state that has forced you to your knees for decades - is a necessary life-preserving measure.

In this chapter, I have argued that citizenship in northern Uganda is learned in two different but interlinked arenas: first, at spectacular moments of state performance, at which citizens, as members of the audience, are guided towards particular forms of subdued participation; and, secondly, in everyday encounters with representatives of the state, which guide citizens towards particular sets of subdued dispositions. This analysis brings into focus how a sense of citizenship, and thereby practices of citizenship, are learned through embodied experiences: by taking part in public debate; by voting; by greeting a flag and singing the anthem; but also by running away when the army burns your home; by being raped by a soldier; by staying quiet for fear that spies are listening; by having your eyes sting from teargas as the police break up a political rally; by staying quiet and averting your eyes when the president declares that you and your people are good for nothing. The broader lesson to draw from this observation is that, whatever the means one wishes to deploy for fostering growth into citizenship, these means must commence from recognition and analysis of the everyday practices and spectacular events through which existing modes of citizenship have emerged.

\section{Note}

1 During the cattle raids that followed the NRA take-over in 1986, cattle numbers in Acholi decreased from an estimated 123,375 head to between 3,000 and 11,000 (Finnström 2008, 73).

\section{References}

Alava, H. (2008). Interactions of conflict and development intervention in northern Uganda (Master's thesis, University of Helsinki, Helsinki, Finland). Retrieved from https://helda.helsinki.fi/handle/10138/13050

Alava, H. (2017a). Homosexuality, the Holy Family and a failed mass wedding in Catholic northern Uganda. Critical African Studies, 9(1), 32-51.

Alava, H. (2017b). There is confusion: The politics of fear, silence and hope in Catholic and Anglican northern Uganda (Doctoral dissertation, University of Helsinki, Helsinki, Finland).

Alava, H. \& Ssentongo, J. (2016). Religious (de)politicization in Uganda's 2016 elections. Journal of Eastern African Studies, 10(4), 677-692.

Atkinson, R.R. (2010). The roots of ethnicity: The origins of the Acholi of Uganda before 1800 (2nd ed.). Fountain Studies in East African History. Kampala: Oxford. 
Branch, A. (2003). Neither peace nor justice: Political violence and the peasantry in northern Uganda, 1986-1998. African Studies Quarterly, 8(2), 1-31.

Branch, A. (2007). Uganda's civil war and the politics of ICC intervention. Ethics \& International Affairs, 21(2), 179-198.

Branch, A. (2011). Displacing human rights: War and intervention in northern Uganda. New York: Oxford University Press.

Branch, A. (2012). The paradoxes of protection: Aligning against the Lord's Resistance Army. African Security, 5(3-4), 160-178.

Butler, J. (1992). Mbembe's extravagant power. Public Culture, 5(1), 67-74.

Dolan, C. (2009). Social torture: The case of northern Uganda, 1986-2006. New York: Berghahn Books.

Fanon, F. (1967). The wretched of the Earth. Harmondsworth: Penguin Books.

Finnström, S. (2006). Meaningful rebels? Young adult perceptions on the Lord's Resistance Movement/Army in Uganda. In C. Christiansen, M. Utas \& H.E. Vigh (Eds.). Navigating youth, generating adulthood: Social becoming in an African context (pp. 203-227). Uppsala: Nordiska Afrikainstitutet.

Finnström, S. (2008). Living with bad surroundings: War, history, and everyday moments in northern Uganda. Durham, NC: Duke University Press.

Finnström, S. (2009). Fear of the midnight knock: State sovereignty and internal enemies in Uganda. In B. Kapferer \& B.E. Bertelsen (Eds.). Crisis of the state: War and social upheaval (pp. 124-142). Oxford and New York: Berghahn Books.

Finnström, S. (2012). 'KONY 2012', military humanitarianism, and the magic of occult economies. Africa Spectrum, 47(2/3), 127-135.

Freire, P. (1990). Pedagogy of the oppressed. London: Penguin Books. (Original work published 1968).

Gollin, D. (2010). Agriculture, roads, and economic development in Uganda: Edited by Richard Rogerson (NBER Working Paper Series No 15863). The National Bureau of Economic Research. Retrieved from www.nber.org/papers/w15863

Golooba-Mutebi, F. \& Hickey, S. (2010). Governing chronic poverty under inclusive liberalism: The case of the Northern Uganda Social Action Fund. Journal of Development Studies, 46(7), 1216-1239.

Karlström, M. (2003). On the aesthetics and dialogics of power in the postcolony. Africa, 73(1), 57-76.

Kleinman, A. \& Kleinman, J. (1994). How bodies remember: Social memory and bodily experience of criticism, resistance, and delegitimation following China's Cultural Revolution. New Literary History, 35(3), 707-723.

Mbembe, A. (1992). The banality of power and the aesthetics of vulgarity in the postcolony. Public Culture, 4(2), 1-30.

Mbembe, A. (2001). On the postcolony. Berkeley: University of California Press.

Mbembe, A. (2006). On the postcolony: A brief response to critics. African Identities, 4(2), 143-178.

Meinert, L. (2015). Tricky trust: Distrust as a starting point and trust as a social achievement in Uganda. In A.L. Dalsgård, S. Liisberg \& E.O. Pedersen (Eds.). Anthropology and philosophy: Dialogues on trust and hope (pp.113-136). New York: Berghahn Books.

Mwenda, A. (2010). Uganda's politics of foreign aid and violent conflict: The political uses of the LRA rebellion. In T. Allen \& K. Vlassenroot (Eds.). The Lord's Resistance Army: Myth and reality (pp. 45-58). London and New York: Zed Books. 
Mwenda, A.M. \& Tangri, R. (2013). The politics of elite corruption in Africa: Routledge studies on African politics and international relations. New York: Routledge.

Niringiye, D.Z. (2017). Conclusion. In P. Musana, A. Crichton \& C. Howell (Eds.). Ngoma Series Vol. 1: Ugandan churches and the political centre (pp. 242-257). Cambridge: Cambridge Centre for Christianity Worldwide.

Nordstrom, C. (2004). Shadows of war: Violence, power, and international profiteering in the twenty-first century. Berkeley: University of California Press London.

Porter, H. (2016). After rape: Violence, justice and social harmony in Uganda. Cambridge: Cambridge University Press.

Prunier, G. (2004). Rebel movements and proxy warfare: Uganda, Sudan and the Congo (1986-1999). African Affairs, 103(412), 359-383.

Tapscott, R. (2017). The government has long hands: Institutionalized arbitrariness and local security initiatives in Gulu, northern Uganda. Development \& Change, 48(2), $263-285$.

UBOS (2010). Uganda census of agriculture 2008/2009. (Summary Report, Volume 1). Retrieved from www.ubos.org/onlinefiles/uploads/ubos/pdf\%20documents/UCA Summary.pdf

UBOS (2014). Census 2014 report Northern Region: National population and housing census 2014 subcounty report. Retrieved from www.ubos.org/onlinefiles/uploads/ ubos/census_2014_regional_reports/Census_2014_Report_Northern_Region.pdf

UNDP (2015). Uganda human development report 2015: Unlocking the development potential of northern Uganda. Retrieved from http://hdr.undp.org/sites/default/files/ undpug2015_ugandahdr2015.pdf

Verma, C.L. (2013). Guns and tricks: State becoming and political subjectivity in wartorn northern Uganda (Unpublished doctoral dissertation). University of Copenhagen, Denmark.

Vokes, R. \& Wilkins, S. (2016). Party, patronage and coercion in the NRM'S 2016 reelection in Uganda: Imposed or embedded? Journal of Eastern African Studies, 10(4), 581-600.

Whyte, S.R. (2002). Subjectivity and subjunctivity: Hoping for health in Eastern Uganda. In R.P. Werbner (Ed.). Postcolonial subjectivities in Africa (pp. 171-190). London \& New York: Zed Books.

Whyte, S.R. (2005). Uncertain undertakings: Practicing healthcare in the subjunctive mood. In R. Jenkins, H. Jessen \& V. Steffen (Eds.). Managing uncertainty: Ethnographic studies of illness, risk and the struggle for control (pp. 245-264). Copenhagen: Museum Tusculanum Press.

Zeller, W. (2013). Get it while you can: Governance between wars in the UgandaSouth Sudan borderland. In B. Korf \& T. Raeymaekers (Eds.). Violence on the margins: States, conflict, and borderlands (pp. 193-217). Palgrave Series in African Borderlands Studies. New York: Palgrave Macmillan US. 


\title{
8 Gendered citizenship in rural Uganda Localized, exclusive and active
}

\author{
Alice N. Ndidde, Karembe F. Ahimbisibwe and \\ Tiina Kontinen ${ }^{1}$
}

\section{Introduction}

This chapter scrutinizes ways in which practices in which citizenship is constructed are embedded and interwoven in local contexts and existing power relations (Holma \& Kontinen, this volume; Robins et al. 2008; Gaventa \& Barret 2010). From the pragmatist point of view, we contend that social experience is an arena for formulating and maintaining habits: the taken-for-granted ways of thinking and doing, which includes a "habit of making social classifications" by attributing distinctive characteristics (Dewey 1922/2012, 12), in this case, between the roles and responsibilities of those perceived as "men" and "women" in society. The notion of habit resonates with the much-discussed difference between citizenship as a status and as lived experience (Kabeer 2005), or between formal and substantial citizenship (Lister 2003). Understanding existing habits also has implications for designing interventions aimed at strengthening women's citizenship and, hence, narrowing this gap between legal status and lived experience. In this chapter, based on interviews conducted in two districts, Kiboga and Namutumba, in Uganda (Ahimbisibwe et al., this volume), we examine the experiences and perceptions of gendered citizenship articulated by rural inhabitants who had previously participated in some activities of a Uganda gender-advocacy NGO, Action for Development (ACFODE) (Kontinen \& Ndidde, this volume). Based on the findings we argue that the lived experiences and daily practices of female citizens differ from their legal status in rural Uganda to date.

We begin by discussing the concept of gendered citizenship and some of the main critical debates concerning citizenship in feminist literature, followed by the discrepancies related to women's citizenship in legislation, policy and practice in the context of Uganda. We then identify and discuss localized, gendered habits of citizenship that emerged out of the various lived experiences articulated by both men and women. Women's local practices can lead to the reformulation of habits, thus creating spaces for a novel kind of active citizenship that references change in lived experiences that bring them closer to the idea of legal status with equal rights. These changes might not 
represent radical transformations in gendered citizenship, but they do constitute a disruption and trigger incremental change in these habits (Holma et al. 2018). Participation in groups and other community activities might gradually enable women to gain the confidence, capacity and opportunities to enjoy their legal status as citizens. In conclusion, we argue that from the perspective of habits and lived experience, citizenship appears gendered, contested and contradictory, but nevertheless, includes possibilities for reformulation of habits.

\section{Gendered citizenship: Towards lived experience}

One of the mainstream meanings of citizenship is membership in a state. In this approach, citizenship rights and duties defined in the national constitutions are perceived to apply equally and neutrally to all individual members of the nation, without distinguishing on the basis of gender, race, class, ethnicity or any other social relation that marks the everyday life of citizens (Meer \& Sever 2004). The discrepancies between citizenship as a legal status and the lived experiences of citizenship have, however, motivated a wealth of development interventions whose aim has been to raise people's awareness of their legal rights in order to change gendered practices. When we understand change and learning from the point of view of reformulation of habits (Holma \& Kontinen, this volume), it becomes important not only to highlight the discrepancies, but also to understand the habits in which the lived experiences are embedded; this facilitates exploration of the ways liberal imaginaries of a free individual enjoying citizenship rights fail to resonate with perceptions embedded in lived inequalities (Lazar 2013; Robins et al. 2008).

Feminist scholars have presented similar critiques of the concept of citizenship in general (Young 1989; Lister 1997) and the lack of gendered analysis in development contexts in particular (Meer \& Sever 2004). One of the critiques revolves around how the notion of citizenship is tied to public and political spheres, thus excluding the domestic spaces and care work where much "female" activity has habitually been located (Preece 2002; Lister 1997). These gendered roles locate women and their concerns outside the realms of citizenship, and their contributions to society are not valued as worthy of membership in terms of decision-making and public processes (Chari 2009). Further, women are seen as passive citizens in need of protection rather than active citizens negotiating their rights (Bhargava 2005). Additional concerns in critiques of gendered citizenship relate to access to infrastructure, housing and livelihoods. Entitlements to ownership and property inheritance are also often divided in gendered ways that do not make economic agency equally possible (Chari 2009).

Critical observations on the gendered nature of citizenship have been accompanied by suggestions that the notion of citizenship as legal status and membership in the state could be augmented through analysis of 
experienced citizenship and the politics of belonging in a variety of communities (Yuval-Davis 2012; Preece 2002). In this view, citizenship, rather than mere legal status and formal rights enshrined in legal and state policy documents, is seen as an active process and an identity based on the expression of one's membership in a variety of communities in different spaces in society (Chari 2009; Clarke et al. 2014). Citizenship is about negotiation, identity, experience and relationships that potentially promote participation and women's agency (Meer \& Sever 2004; Mukhopadhyay et al. 2010; Yuval-Davis 2012); it is, however, important to keep in mind that communities that provide identity are themselves gendered, and often characterized by patriarchal habits and male domination (Meer \& Sever 2004; Chari 2009; Mukhopadhyay 2007). For example, factors such as culture, religion and colonialism have affected gendered citizenship, both in practice and in legislation (Ramtohul 2009). Meanwhile, the efforts made by women's movements with the goal of transforming gendered roles that are considered unequal, have often been labelled "anti-social order movements", and accused of trying to appropriate men's positions in opposition to the dictates of "natural roles" (Mukhopadhyay 2015).

To understand these gendered debates has been considered a necessary condition for designing development initiatives, which require "both greater depth and greater breadth with regard to the ways in which gender (in)equality is conceived and addressed" (Staab \& Razavi 2015). Acknowledging the gendered lived experiences of citizenship calls for grounded analysis of power and equality rather than understanding interventions as technical operations (Meer \& Sever 2004) or as matters of simple awareness raising. Therefore, we opted for a grounded analysis of the understanding of notions of "citizenship" and practices in which women in rural areas participate. Before proceeding to the accounts of experienced citizenship, however, we first examine the "other side of the coin": the discrepancies related to women's citizenship in legislation, policy and practice in Uganda.

\section{Gendered citizenship as status: Analysis of discrepancies in the Ugandan environment}

When it comes to citizenship as a legal status, Uganda is, to date, regarded as one of the pioneer countries in the African region to spearhead and strengthen women's rights at all levels of society through legislation and policy formulation (UWONET 2018; Ahikire \& Mwiine 2015); indeed, the state has legislated extensively to grant citizenship rights to both men and women. These include, for instance, entitlements to the right to protection, access to basic services including education, equal rights during marriage and at its dissolution, protection against gender-based violence and the right to political representation and participation. ${ }^{2}$ In what follows we offer a brief overview of the legislation and policies geared to secure women's rights, and thus, determine their status as citizens. 
Uganda's 1995 Constitution, in the section of principles concerned with the protection and promotion of fundamental and other human rights, categorically declares that "the State shall ensure gender balance and fair representation of marginalized groups on all constitutional and other bodies" (Principle vi), and "the State shall recognize the significant role that women play in society" (Principle xv). Within the same Constitution there are several articles emphasizing the human rights of women and other marginalized groups. Article 21 affirms equality and freedom from discrimination when it states:

All persons are equal before and under the law ... a person shall not be discriminated against on the grounds of sex, race, color, ethnic origin, tribe, birth, creed or religion, or social or economic standing, political opinion or disability.

Article 32, on the other hand, addresses affirmative action on behalf of women and other marginalized groups, stating:

Notwithstanding anything in the constitution, the State shall take affirmative action in favor of groups marginalized on the basis of gender, age, disability or any other reasons created by history, tradition or custom for the purpose of redressing the imbalances which exist against them.

Article 33 is remarkable in that it is very specific about the rights of women and lists areas where the welfare and dignity of women shall be protected.

Through various ministries and in collaboration with civil society, the Government of Uganda has instituted policy frameworks, sector-specific policies and strategies geared towards the enhancement of the status of women and girls within this legislative context. Significant among the policies is the Uganda National Gender Policy (2007) which mandates gender mainstreaming in all planning, resource allocation and implementation processes by development programs in Uganda. The ultimate goal of this policy "is to achieve gender equality and women's empowerment as an integral part of Uganda's socio-economic development". All other national and sectoral policy/plan documents include an analysis of gender issues in their particular sectors and the formulation of strategies for addressing gender imbalances and inequalities. ${ }^{3}$

However, structural forces - including power and politics (Ahikire \& Mwiine 2015) and socio-cultural and economic gender dynamics (Asiimwe 2002; Babikwa 2003; 2004; Ndidde 2004; ACFODE 2014; UWONET 2018) shape the realization of women's citizenship rights and gender equity in Ugandan state policy adoption and implementation, and the extent to which the policies are practiced. Politics of patronage and clientelistic practices (Ssali Lukwago 2016; Ahikire \& Mwiine 2015; Tripp 2010; Alava, this volume), ignorance of the existence of the laws, and poverty, discrimination, 
subordination and social exclusion are key factors in Uganda that deny women access to, or the exercise of, their citizenship rights. Exacerbating this situation, sometimes law enforcement agencies, especially in rural areas, are not aware of the rights secured by Ugandan legislation (Khadiagala 2001). For example, a review of the implementation of the affirmative action policy in Uganda with specific reference to women's participation in politics carried out by ACFODE (2014) revealed that, despite the achievements, women's political participation and emancipation is still constrained by an interplay of factors arising from the internal functioning of the state but also embedded in socio-economic and cultural gender dynamics. Ahikire and Mwiine (2015), who have scrutinized the ways in which power and politics shape the realization of women's rights and gender equity in Ugandan state policy adoption and implementation, have examined the processes undertaken to adopt the Domestic Violence Act of 2010. They found that political patronage and "politics of compromise" have undermined the transformative elements contained in the Domestic Relations Bill of 2003. The DVA

emerges as a more tokenistic form of legislation that has barely moved from the statute books and was perhaps offered more as a means to appease a more marginal constituency upset by the loss of more radical legislative reforms (around DRB) than through any genuine commitment.

(Ahikire \& Mwiine 2015, 28)

Additionally, the "implementation of UPE [is] largely cast as a presidential gift of patronage, rather than as a right". Overall, they conclude (ibid.) that the state views women "as clients and not citizens with rights".

Against this backdrop, what is experienced as gendered citizenship might not resonate with legally guaranteed citizenship rights in the Ugandan context. The status of citizen is not enough without the conditions to enable such citizenship to be experienced and practiced. Formal, legal equality is not sufficient to ensure women can access their rights. Moreover, not only does formal or legal equality not guarantee real equality, it also hides inequalities because legal entitlement to rights and resources may be seen as actually exercising those rights or receiving the entitlements in reality.

\section{Lived experience of gendered citizenship: Localized, exclusive and active}

In this section, we discuss gendered citizenship as experienced and articulated in the interviews we conducted with rural inhabitants who had previously participated in the activities of ACFODE, a renowned Ugandan gender advocacy NGO (see Kontinen \& Ndidde, this volume). We interviewed 60 participants out of whom nine were men. We were interested in how gendered citizenship was constructed and articulated and the ways in which participation in localized practices as well as NGO activities offered opportunities and spaces for change in gendered habits. 
The analysis showed that instead of referencing their status as a state member, the participants framed the notion of "citizenship" in terms of "community seatedness", which represented a meaningful sphere of belonging. Formal citizenship was often discussed in terms of how a "good citizen" was framed in a gendered way, often based solely on male characteristics. Moreover, while it was typical for women to exclude themselves from such citizenship, they nonetheless positioned themselves as belonging and being active members in multiple groups. These groups and other practices provided new ideas and ways of operating that eventually diminished, to some extent, the gap between lived experience and legal status. In what follows we discuss in detail the contestations and contradictions of citizenship that appeared when it came to localized citizenship, self-exclusion, community exclusion and multiple belongings.

\section{"Localized" understandings of citizen and citizenship}

An important aspect of researching the lived experiences of citizenship is identifying the ideas and words in local languages used to refer to the English-language notion of "citizenship". During translation of the research tool, the research team decided to adopt omutuuze as the direct equivalent of the word citizen in Luganda. Initially the tool was translated into Luganda ${ }^{4}$ on the understanding that omutuuze would suffice in both Kiboga and Namutumba. However, when the research team went to Namutumba District in Busoga Region, the word omutyamye in Lusoga - the local language - was used to refer to a citizen. Literally, omutuuze implies someone who resides/ lives in a given area (Kiingi 2007), while omutyamye implies one "who is seated". In practice, both words emphasize the importance of community "seatedness" and participation in the affairs of a given area. They further emphasize a citizen as someone who is settled and lives with an acceptable level of permanence in a given area, a state defined, for instance, by owning land and having a house and family, as well as engaging in community affairs.

Omunansi is another term related to citizenship in both Luganda and Lusoga which literally means, "of the soil/earth". This term is generally and loosely used to mean a national, a person born in a given country. Conversations with the participants about the differences between omunansi and mutuuze/mutyamye revealed a distinction between what could be termed a "resident citizen" (mutuuzelmutyamye) and national or "freelance" citizen (omunansi). The resident citizen is someone with whom community members can identify due to his/her shared residence (butuuze/butyamye) and engagement in all activities considered important for the survival and livelihood of the community. On the other hand, the national citizen, omunansi, is someone who is born and resides in the larger country/nation and is in possession of a national identification card. However, a national citizen (munansi) only attains local citizenship after having lived in a community for a long period of time, sharing its general identity, as one of the participants explained: "Like 
you [the researcher], you're a national [munansi] but not a citizen [mutuuze]. You are a Ugandan but you have no residence here since you have another place where you come from." In view of the above discussion, and as the focus of our research project lies on citizenship as lived experience and as something that takes place in everyday life, we decided to use the word omutuuze in Luganda and omutyamye in Lusoga to refer to a citizen.

The definition of citizenship as a condition related to rights and legal frameworks seems rather distant from subjective experiences, where the outstanding characteristics of a citizen which were articulated included permanent residence in a community and having a home, family in the area, as well as ownership of property, especially land. In addition, the definitions focused on localized citizenship obligations and less on rights, suggesting people "of good conduct [who] respect the community code of conduct; if it is road maintenance, [they] should participate, in case of any occurrence, [they] should assist other people. In other words, that is good citizenship [obutuuze obulungi]." In contrast, national citizenship was discussed mainly in terms of material artefacts such as a national identification card or being a registered voter; even then, however, belonging to the local area and having a local identification document was still emphasized:

Citizenship [omunansi] is about one who is a Ugandan, in Uganda, who has documents that justify that [he/she] is a Ugandan. ... That is citizenship ... and if that person lives here at "Isegero B" must have another document that justifies he/she is a resident of Isegero " $\mathrm{B}$ ". That is citizenship and [proves] that he/she is a true resident citizen since such a person has, for example, a village identification document which proves that that person is a bonafide resident of Isegero " $\mathrm{B}$ ".

(Research participant in Namutumba)

Clearly, the localized view of the notion of citizenship intertwines the national with the local. Often, too, the localized ideal of citizenship is linked to family history within a particular place of origin:

A citizen must be permanently in one place [and work] together with the other people in the village. . . . My parents [are] from here, they produced me here, I grew up here, and when my father died, I married a woman [from here]. I have stayed on my father's land; I am still producing children on my father's land, and I am growing old expecting also to raise my grandchildren in this area.

(Male participant in Namutumba)

The significance of family lineage connections with a certain localized place was also related to the membership of certain ethnic group, which, in Ugandan contexts, closely relates to the geographical division of the country (Alava et al., this volume). 
In my view, a citizen is a person who is born in a "tribe" [ggwanga], for example, like in Buganda. As long as you are born in that area [you are a citizen there], and more so when your parents were at one time citizens of that area.

(Female participant in Kiboga)

In light of the above discussion, it becomes apparent that the basic understanding of the notion of "citizenship" in the rural communities and as translated into local languages in Uganda centres on community belongingness and identity, permanence of residence and participation in local community activities. These represent more significant and meaningful spaces of citizenship than the nation, where the latter is less acknowledged.

\section{Women's self-exclusion from being citizens}

In this section, we discuss gendered citizenship habits and practices made apparent in the various lived experiences articulated by the men and women with whom we interacted. The gendered nature of citizenship was both explicitly and implicitly embedded in the participants' views. Where a citizen was characterized as such by virtue of owning a permanent residence and/or property, especially land, in the area, and fulfilling family obligations like meeting food and clothing needs and paying school fees for the children, it implicitly referred to the characteristics of a male citizen. Additionally, both women and men participants referred to a woman as being part of the trappings of a good (male) citizen. As one female participant articulated: as a good citizen, "You have to have your home [house], you have to have a woman, you have to have children; also, you have to have animals in your home." Thus, characterizations of a (good) citizen were largely built on sociocultural beliefs and practices in which owning a home and property and meeting family obligations are duties, rights and obligations attached to the men of the society. It follows, then, that the above views implicitly exclude women from the definition of citizens in the locality; indeed, the status of a female citizen was often constructed vis-á-vis her relationship with a male, either a father or a husband.

Now a woman becomes a citizen of where she is living, so if she has been chased away, then she ceases to be a citizen. . . . Because men retain everything, even if you both worked so hard to get them; all of it remains his because it's a woman who comes to live with him.

(Female participant in Kiboga)

In addition to the implicit embeddedness of citizenship within the patriarchal register, women also explicitly excluded themselves from the definition of localized citizen. The following excerpt from a dialogue between a wife and 
husband illustrates the ways in which the localized citizenship of women is both flexible and transient, as it changes along with the change of spouse:

INTERVIEWER: So now, is a woman also a citizen?

WIFE: A woman! [Laughter] A woman! It is difficult. For example, like me here, Sarah, today I can say that I am a resident/citizen here. If a time comes that we separate [this man and I], I will get another man and go.

HUSBAND: Me as the man, I am the citizen [mutyamye] because I cannot leave this place to go and get married elsewhere. But for a woman, it is true, she can be a citizen [mutyamye] but when you get a disagreement here, she just leaves. So she can no longer be a citizen [mutyamye] here.

INTERVIEWER: But she may be born in that community. . .

WIFE: Even if I am born in this area, if something happens, I just leave.

HUSBAND: As a woman, she may have resident citizenship [obutyamye] but only short term. That is why they say that a woman has no religion, because she gets her religion where she gets married. When she marries a Muslim, she also becomes a Muslim. When she marries a Born Again she also becomes one.

WIFE: . . . and in the same way, they do not have citizenship.

HUSBAND: They do have, but it is limited.(Participant couple in Namutumba)

However, these perceptions also seemed fluid and in a process of change, as illustrated by the following example:

Women are also citizens [abatyamye]. I am a woman but I have citizenship [obutyamye] here because I have my home here. I am also registered in the book of bataka ${ }^{6}$ and they know that Betty is based here and she is a resident citizen [mutuuze] of this community . . . even when you may not be married, with a husband, or when the marriage has failed. Nowadays, women are also given land from their ancestral homes. Someone may say, "That land is for my girl child." So she also comes to settle and build for her children. That qualifies her to become a citizen [omutuuze] of a particular community.

(Female participant in Namutumba)

Ultimately, given the lived experiences of the participants, we can conclude that citizenship and being a citizen was in the majority of cases framed in a gendered manner, often only incorporating the characteristics of a male citizen, with patriarchal attitudes influencing citizenship practices and women excluding themselves from the category.

\section{Gendered exclusion in a community through habits and practices}

In this section we discuss experiences of gendered habits and practices involving community restrictions and gender-differentiated citizenship activities. 
While women consciously and unconsciously excluded themselves from their legal right to citizenship, they also reflected on the ways in which they were either included or excluded by the community wherein members' gendered habits, embedded in culture and religion, have been formed over decades or centuries of upbringing. For women, these habits include taken-for-granted assumptions and control over what they can and cannot do, and for both women and men, they are so deeply rooted that it is a challenging task to change them by means of government legislation (Asiimwe 2002; SebinaZziwa 1999). Some of the women participants in this study felt that it was extremely difficult for them to become citizens in a given locality as becoming a citizen depended on whether a person was settled in marriage or not. Women often held the belief that being a woman automatically disqualifies them from being an independent citizen of a locality. In Namutumba, this view was especially embedded in cultural norms among Basoga women and men, who believe in male supremacy. Hence the adage, omwami kyakoba nzeena kye kola, which literally means being subordinate or submissive to men's views and practices.

The community as a whole has a final say in whether a woman can be perceived as a citizen or not. Often, women's endeavours to assert themselves as active citizens are sanctioned as misbehaviour and a breach of society's norms (Mbire-Barungi 1999; Ovonji-Odida 1999; Asiimwe 2002), while other practices may even result in ostracization or exclusion from the category of citizen (butyamye). In Namutumba, behaviour in this category that was mentioned by the participants included adultery, pride, promiscuity, or failure to participate in community work (Bulungi bwansi).

A woman might have what we call pride. When she is proud around the community, she is adulterous and goes out with every man. So sometimes, because of her behaviour, people may not regard her as a resident of that village. And so she might be denied settlement at that particular community for the reason that she goes out with people's husbands.

(Female participant in Namutumba)

In conclusion, a woman's acceptance as a resident citizen is determined by the community as a whole. Such communities are themselves gendered, and often characterized by deep-rooted patriarchal habits and male domination.

\section{"Localized" practices and multiple belongings as spaces for disruption in gendered habits}

The formal and legal status of being a citizen allows Ugandan women to make claims as citizens in their own right (The Constitution of the Republic of Uganda 1995). However, analysis of the narratives of the participants revealed that, for a woman, being recognized as a citizen, or further, an "active citizen", does not come on a silver platter; in reality, it is a struggle. 
Women must negotiate between different categories of citizenship that are themselves continuously evolving: "Women are now recognized as citizens through their own efforts", said one of the participants of the recent changes. The existence of multiple identities and belongings, and participation in the different activities of formal and informal groups and organizations, characterize this struggle. If one regards learning as the reformulation of habits, it is essential to ask what might function as a disruption that would trigger changes in the habits of gendered citizenship. On the basis of the analysed narratives, changes seem to result from an aggregated engagement with, and participation in, a number of groups over time rather than any specific event or intervention. Two participants' reflections on the results of their taking part in various community activities were as follows:

All the above have changed my way of thinking as a woman. I no longer sit back and wait for my husband.

(Female participant in Kiboga)

When there are meetings, I participate in those meetings. Usually when someone participates in a meeting with three or five people, you cannot leave with the same brain. Something special happens... the brain changes.

(Female participant in Kiboga)

For instance, one of the key steps in gaining recognition as a local citizen is by joining and participating in Village Savings and Loan Associations (VSLAs) (see also Kilonzo et al., this volume). Each of the women participants belonged to at least two or more VSLAs, engagement with which enabled them to accumulate savings, which would, in turn, be loaned out with interest. The savings and interest on the loans would be shared at the end of the year. The VSLAs enabled women to invest in other income-generating activities, the acquisition of assets such as land and the construction of buildings for different purposes, both residential and commercial. Economic empowerment gained through the VSLAs also strengthened women's agency and their experience of being competent citizens. As noted by two women in Kiboga:

Before I joined TukolereWamu, I depended so much on my husband. He was the one to provide all the basic household necessities. I would feel helpless in case he was unable to provide for us. But when I joined TukolereWamu, we learnt how to work. ... I could not contribute to the school fees of even one of my children. But now, the things I have learnt in TukolereWamu have provided me with the capacity to pay fees for at least one child. 
[B]ut the most important thing is that this group has made me develop as a person. Truly, before I joined it, I was badly off: poverty, sickness and even ignorance. Yes, I used to survive as a person but there was something missing [that would allow me] to be a good citizen among people, a person fit to live in a community. But now, I can stand and teach my colleagues; I can even "teach" community members.

(Female participant in Kiboga)

This economic struggle for identity and belonging has enabled women to gain financial empowerment, which is exhibited in their ability to contribute to meeting family obligations like school fees for their children, medical bills and other home requirements. Furthermore, the entire process of struggling for identity and belonging through economic engagement has enabled women to gain confidence and assert themselves in the local community. Consequently, the overall process has enabled women to gain knowledge and diverse skills in leadership, public speaking, financial management, saving and investment.

Other practices that provided meaningful participation included, for instance, involvement in local politics, with the majority of women leaning towards the ruling National Resistant Movement Party (NRM); religious affiliation, especially Anglican, "Born Again", Muslim and Catholic; and community based socio-cultural groups. According to the experiences of women in Namutumba District, the process of gaining recognition as a local citizen involved going through certain "rites of passage", occurring when a woman gets married and is coached by a senior woman citizen on the practices of a "proper local woman citizen" over the period of a year. Once accepted as a mutaka (local citizen) she is required to fulfil specific, genderdifferentiated duties, obligations and responsibilities:

Here as women we also make local contributions [Ife wano ewaife tuwayo obutaka]. We women, we carry food and fetch water when we lose a member of the community ... that is what makes us [women] recognized as citizens in the area ... The men contribute money, construct shelter and dig the grave; we, the women, we carry food and fetch water - that is how we fulfil our community obligations [n'obutaka bwaife bwe tukola].

(Female participant in Namutumba)

As with economic empowerment, women gain recognition in community groups through being subjected to a complex specific process quite different from that of their male counterparts. It is clear that the identity ascribed to women is still, in reality, often shaped by their relations to a man, whether as a mother, daughter, sister or wife. Nonetheless, religious affiliation as an avenue to recognition as local citizens involved women both as part of the laity but also as active participants in church-related activities, while filling different roles in the church. Some were choir members, others occupied 
positions as deaconesses, chairpersons of women church groups and secretaries; still others were members of church youth or women's groups. While many said that there were no tangible benefits, the prayers and blessings were very important for their survival and the success of their day to day activities:

[I]t is true, if you put something first, it should be religion. Without God, all these other activities/jobs can collapse. Therefore, when I go to the church, I go there to pray, and I have other church activities which I can do ... My expectations of St Cecilia are not high. But I belong to it for a reason: you cannot manage the group's business on... when God is not there. For that matter, I belong to the church mainly for proper guidance in all these other activities I do. Because if you do not have religion here, all the other activities do not go well.

(Female participant in Kiboga)

The ways in which women struggle to gain recognition as citizens do not form a single trajectory but, rather, a nexus of multi-membership whereby, on the one hand, they engage in different practices in each of the communities/ groups to which they belong, behaving differently as they construct different aspects of themselves and gain a range of perspectives; on the other hand, the latter notwithstanding, the overriding requirement of identity-formation is the ability to participate, interact and influence each other, leading to the reformulation of habits. Overall, taking part in local practices, belonging to multiple informal community groups and to churches and religious groups, and participating in local politics and formal organizations has led to the gradual reformulation of taken for granted habits and, thus, created spaces for women's visibility, agency and active citizenship.

\section{Conclusions}

Our analysis has showed that Ugandan women, especially in rural communities, are still struggling with discrepancies between citizenship as a legal status and their lived experience, between entitlements granted in government legislation and social controls exercised in everyday life. We contend that it is not a question of women's intentional reluctance to enjoy their incontestable rights, nor of their being unaware of them or scared of cultural reactions if they practice them more actively (Mbire-Barungi 1999; Meer \& Sever 2004; Wyrod 2008); rather, their lived experience is the result of gendered habits formulated over history. When it comes to learning as a reformulation of these habits, there is no abrupt and direct shift from one condition to another, from a socially-constructed, gendered citizenship to a universally equal one. Instead, prevalent concepts undergo incremental change whereby new ideas, actions and processes act as disruptions, generating additional perceptions of different kinds of citizenship. Furthermore, it is not enough to assume that gendered citizenship in society can be transformed by means of written 
statutes, or by allocating positions for women, designing policy instruments or delivering authoritative speeches wherein citizenship is primarily discussed in national terms: not as long as the experienced citizenship mostly revolves around localities. The notion of citizenship should be sufficiently contextually relevant to accommodate negotiated, experienced, localized perspectives. Consequently, interventions aimed at strengthening citizenship should recognize and take advantage of the complex nature of women's multiple relationships in their local contexts, using them as entry points for holistic transformation.

\section{Notes}

1 The first author has had overall responsibility for the chapter. The first and the second authors have conducted the fieldwork presented, initiated the overall idea and contributed substantially to each section. The third author is a PI of the project. She has contributed to the theoretical content and the overall structure.

2 Refer to the Constitution of the Republic of Uganda (1995); the Local Government Act (1997); the Land Act (1998), the Education Act of Uganda (2008), the Uganda Domestic Violence Act (2010); the Prohibition of Female Genital Mutilation Act (2010); the Equal Opportunities Act (2010).

3 Some of the sector policy/plan documents include Uganda Vision 2040, Second National Development Plan 2015/16-2019/20, Social Development Plan (SDIP-2), Agriculture Sector Strategic Plan 2015/16-2019/20, Health Sector Strategic Plan, Education and Sports Sector Strategic Plan 2017/18-2019/20

4 Luganda is the local language of the Baganda of central Uganda but also widely spoken across the greater southern part of the country.

5 In the understanding of the participants, omunansi acts like a freelance person with neither community attachment and responsibility nor permanence in the community. Some of the examples given included casual and/or migrant labourers, distant visitors and in some cases women.

6 Bataka is the plural of Omutaka. Omutaka according to Basoga social practices is a registered member of a local community who is obligated to fulfil prescribed community maintenance roles. To be registered as a member (mutaka) one pays an agreed sum of money to the treasurer and is registered in the "book of bataka".

\section{References}

ACFODE (2014). A research report on the review of affirmative action policy in Uganda (A printed research report). ACFODE.

Ahikire, J. \& Mwiine A.A. (2015). The politics of promoting gender equity in contemporary Uganda: Cases of the domestic violence law and the policy on Universal Primary Education (ESID Working Paper series, No. 55). Retrieved from https:// ssrn.com/abstract $=2695727$

Ahimbisibwe, K.F., Ndidde, A.N. \& Kontinen, T. (2019). Participatory methodology in exploring citizenship: A critical learning process. In this volume.

Alava, H. (2019). The everyday and spectacle of subdued citizenship in northern Uganda. In this volume.

Alava, H., Bananuka, T.H., Ahimbisibwe, K.F. \& Kontinen, T. (2019). Contextualizing citizenship in Uganda. In this volume. 
Asiimwe, J. (2002). Women and the struggle for land in Uganda. In A.M. Tripp \& J.C. Kwesiga (Eds.). The women's movement in Uganda: History, challenges, and prospects (pp. 119-137). Kampala: Fountain Publishers.

Babikwa, D. (2003). Environmental policy to community action: Methodology and approaches in community-based environmental education programmes in Uganda (Doctoral dissertation, Rhodes University, Grahamstown, South Africa).

Babikwa, D. (2004). The political economy of adult education in Uganda. In A. Okech (Ed.). Adult education in Uganda: Growth, development, prospects and challenges (pp. 35-50). Kampala: Fountain Publishers.

Bhargava, R. (2005). Introduction. In R. Bhargava \& H. Reifeld (Ed.). Civil society, public sphere and citizenship dialogues and perceptions. New Delhi: SAGE Publications.

Chari, A. (2009). Gendered citizenship and women's movement. Economic and Political Weekly, 44(17), 47-57.

Clarke, J., Coll, K., Dagnino, E. \& Neveau, C. (2014). Disputing citizenship. Bristol: Policy Press.

Dewey, J. (2012). Human nature and conduct. Digireads.com Publishing. (Original work published 1922).

Gaventa, J. \& Barret, G. (2010). So what difference does it make? Mapping the outcomes of citizen engagement (IDS Working Paper 347). Retrieved from https://onli nelibrary.wiley.com/doi/abs/10.1111/j.2040-0209.2010.00347_2.x

Holma, K. \& Kontinen, T. (2019). Practices and habits of citizenship and learning. In this volume.

Holma, K., Kontinen, T. \& Blanken-Webb, J. (2018). Growth into citizenship: Framework for conceptualising learning in NGO interventions in sub-Saharan Africa. Adult Education Quarterly, 68(2), 215-234.

Kabeer, N. (Ed.). (2005). Inclusive citizenship: Meanings and expressions. London: Zed Books.

Khadiagala, L.S. (2001). The failure of popular justice in Uganda: Local councils and women's property rights. Development and Change, 32(1), 55-76.

Kiingi, K. (2007). Enkuluze y'Oluganda ey'e Makerere. Kampala: Fountain Publishers.

Kilonzo, R.G., Matunga, B.N., Chang'a, H.H. \& Kontinen, T. (2019). Habits of contributing citizenship: Self-help groups in rural Tanzania. In this volume.

Kontinen, T. \& Ndidde, A.N. (2019). Learning in a Ugandan gender advocacy NGO: Organizational growth and institutional wrestling. In this volume.

Lazar, S. (2013). Citizenship, political agency and technologies of the self in Argentinean trade unions. Critique of Anthropology, 33(1), 110-128.

Lister, R. (1997). Citizenship: Feminist perspectives. New York: New York University Press.

Lister R. (2003). What is citizenship? In J. Campling (Ed.). Citizenship: Feminist perspectives. London: Palgrave.

Mbire-Barungi, B. (1999). Ugandan feminism: Political rhetoric or reality? Women's Studies International Forum, 22(4), 435-439.

Meer, S. \& Sever, C. (2004). Gender and citizenship: Overview report. BRIDGE Cutting Edge Pack. Brighton: Institute of Development Studies.

Mukhopadhyay, M. (2007). Gender justice, citizenship and development: An introduction. In M. Mukhopadhyay \& N. Singh (Eds.). Gender justice, citizenship and development (pp. 1-14). Ottawa, ON: Zubaan and International Research Development Centre. 
Mukhopadhyay, M. (2015). Gendered citizenship in the postcolony: The challenge for transnational feminist politics. In R. Baksh \& W. Harcourtthe (Eds.). Oxford handbook of transnational feminist movements (pp. 607-628). Oxford Handbooks online.

Mukhopadhyay, M., Hunter, C. \& Milward, K. (2010). Gender and rights: A resource guide. Amsterdam: KIT.

Ndidde, N.A. (2004). Meeting the needs of the marginalized in Uganda. In A. Okech (Ed.). Adult education in Uganda: Growth, development, prospects and challenges (pp. 210-224). Kampala: Fountain Publishers.

Ovonji-Odida, I. (1999). Land law reform: Challenges and opportunities for securing women's land rights in Uganda. Paper presented at DFID Workshop on Land Tenure Policy in African Nations. Sunningdale, UK.

Preece, J. (2002). Feminist perspectives on the learning of citizenship and governance. Compare, 32(1), 21-33.

Ramtohul, R. (2009). Women and politics in a plural society: The case of Mauritius (Doctoral Dissertation, University of Cape Town, South Africa). Retrieved from op en.uct.ac.za

Republic of Uganda (1995). The Constitution of the Republic of Uganda. Republic of Uganda: Government Printers.

Republic of Uganda (2007). The Uganda National Gender Policy. Republic of Uganda: Ministry of Gender Labour and Social Development.

Robins, S., Cornwall, A. \& von Lieres, B. (2008). Rethinking 'citizenship' in the postcolony. Third World Quarterly, 29(6), 1069-1086.

Sebina-Zziwa, N. (1999). The paradox of tradition: Gender, land and inheritance rights among the Baganda. (Doctoral Dissertation, University of Copenhagen, Copenhagen, Denmark).

Ssali Lukwago, V. (2016, January 8). Patronage, clientelism and economic insecurity in Uganda. Pambazuka. Retrieved from http://pambazuka.org/en/category/features/ 96316

Staab, S. \& Razavi, S. (2015). Gendered dimensions of development compiled and introduced. United Research Institute for Social Development (UNRISD). Geneva: Oxford University Press.

Tripp, A.M. (2010). Museveni's Uganda: Paradoxes of power in a hybrid regime. London: Lynne Rienner Publishers.

UWONET (2018, March 8). The state of women's rights as a national concern. Press statement by the women's movement in Uganda [Blog post]. Retrieved from www. uwonet.or.ug/the-state-of-womens-rights-as-a-national-concern-2018/

Wyrod, R. (2008). Between women's rights and men's authority: Masculinity and shifting discourses of gender difference in urban Uganda. Gender \& Society, 22(6), 799-823.

Young, I.M. (1989). Polity and group difference: A critique of the ideal of universal citizenship. Ethics, 99(2), 250-274.

Yuval-Davis, N. (2012). The politics of belonging: Intersectional contestations. London: SAGE. 


\title{
9 "A good believer is a good citizen" Connecting Islamic morals with civic virtues in rural Tanzania
}

\author{
Ajali M. Nguyahambi and Tiina Kontinen
}

\section{Introduction}

One of the tasks of this book is to analyse existing practices and the kinds of citizenship habits acquired through participation in them (Holma \& Kontinen, this volume). In sub-Saharan contexts, religious practices provide some of the most important spaces for the exercise of citizenship when understood from the perspectives of belonging and active participation. In this chapter, we approach religion and faith from the pragmatist point of view, as practices of specific communities that offer an everyday space where "the art of living" is developed in interaction with others (Rogers 2009, 109), and citizenship habits are shaped in connection with tradition and fellow community members (Stitzlein 2014, 64). In development, the majority of rights-based initiatives perceive a "good citizen" as an individual actively engaged in claiming personal rights, whereas critiques of this stance have pointed out that people in sub-Saharan Africa tend to be firmly integrated into communities, interpreting experiences from the position of social belonging rather than from that of a right-holder (Robins et al. 2008).

Religious communities as arenas for public life are prevalent examples of social embeddedness. For example, the Afrobarometer survey in 2008 showed that 71 per cent of the adult population in Tanzania identified themselves as being religiously active (Manglos \& Weinreb 2013, 202). In recent years, the close connection between religion and citizenship in Africa has been widely discussed, especially in the context of Christianity and in relation to the spread of the Pentecostal and other charismatic churches (Bompani \& Frahm-Arp 2010; Englund 2011; Jones 2012) that shape the "politics from below" through people's everyday participation (Bompani \& Valois 2017). Thus, exclusion of religion from the design of citizenship initiatives may disregard influential and central elements of everyday identity and agency, resulting in a failure to understand the prevailing ways in which citizens engage. The common separation between "development" and "religion" in development policies becomes obscure from the point of view of everyday experiences, as a person is not a believer at one moment and a liberal state citizen at another. 
In recent research on sub-Saharan Africa, Islamic religion has received relatively little attention, notwithstanding its significant role in the area since the start of so-called "Arab imperialism" on the coasts of the Indian Ocean in the 14 th century. Today, Loimeier $(2007,138)$ places Tanzania in a category of countries with a sizable Muslim population, although no official statistics of religious affiliations in Tanzania ${ }^{1}$ are available. Thus, the Islamic faith plays an important role in the everyday practices of the Muslim population in Tanzania, its religious morals shaping perceptions of a "good citizen". There is, however, no institutionalized connection between Islamic morals and the state, as Tanzania has no official religion. Indeed, throughout its history, there have been both political and everyday contestations between the two "imported faiths" of Christianity and Islam (Ndaluka \& Wijsen 2014; Njozi 2000), although today, religious disputes are more commonly linked to matters of rituals and the interpretive authority of competing Islamic scholars or movements (Loimeier 2007). In contrast to directions taken in the recent expansion in research on Islamic radicalization in East Africa (Kfir 2008; Stith 2010), in this chapter we are, rather, interested in everyday Islam in nonradicalized rural contexts, and the civic virtues considered important by community members themselves.

Building on the pragmatist framework of this edited volume, we contend that, through participating in communities, people acquire habitual ways of addressing the common good and interacting with each other (Stitzlein 2014). In situations where the Islamic faith characterizes the immediate community, Islamic morals are important in defining what is good and appropriate, not only within the religious community, but in also in other spheres of society. In our understanding, habits concerned with general public life, and judged good by the participants in a community, can be labelled civic virtues. Thus, the notion of civic virtues here refers to characteristics of good citizenship as understood by the members of three Islamic communities in rural Tanzania. We ask how community members connect faith and citizenship, and how they reflect on relationships between Islamic morals and civic virtues. Based on our interviews in Kondoa District, we analyse how community members explain and articulate what it means to be simultaneously a good believer and a good citizen. In what follows, we first revisit the conceptual terrain of religion, civil society and civic virtues relevant to our purposes, before briefly discussing the status of Islam in contemporary Tanzania. We then offer an analysis of community members' ideas on religious morals and civic virtues. In conclusion, we reflect on the implications of Islamic morals in shaping particular citizenship habits.

\section{Religion, civil society and civic virtues}

Religion has consistently been a contested area in international development initiatives that focus on strengthening civil society and citizenship. While many influential international NGOs are faith-based organizations, 
development policies often disconnect participation in civil society and in religious life, especially in the liberal view of civil society, which tends to exclude religion from public life. This distinction is based on the argument that negotiations over shared issues in religion do not comprise democratic deliberation, nor are they based on ideas of equal rights; rather, they are dictated by divine doctrine, dogmas and authoritarian rules within hierarchical social systems (Habermas 2006; Sapir \& Statman 2012; Elshtain 2009). However, religion is a significant public space in Africa in which ideals pertaining to the "good citizen" are cultivated and citizens are mobilized to undertake practical initiatives for contributing to the common good, while activeness in religious groups increases participants' civic consciousness in general (Bompani \& Valois 2017; Bompani \& Frahm-Arp 2010; Englund 2011; Jones 2012; Manglos \& Weinreb 2013). As a result of this somewhat artificial distinction between citizenship and religion, the practical designs of education for active citizenship and human rights often encounter what Ahmed $(2012,728)$ calls a "liberal dilemma", which entails the tendency to presuppose a certain kind of individual autonomy that rests on Western "truths considered to be self-evident and universal". These assumptions leave little room for "non-Western people" to challenge these taken-for-granted liberal ideas that they might perceive as "non-negotiable, dogmatic and oppressive" (ibid.). For instance, an autonomous individual as a locus of rights - a view held by many NGO-education initiatives - might appear a strange idea in an Islamic context where the individual is seen as a member of a community of faith in which "goodness is not just an individual matter [and] society has a duty to publicly uphold moral behaviour and religious practice" (Halstead 2007, 289).

The existing biases towards Western political theories and the challenges related to the liberal ideal of civil society in international development have been acknowledged by many scholars (e.g. Chambers \& Kymlicka 2002; Lewis 2002). An "Islamic civil society" that has been proposed as one of the alternatives to a liberal version (Hanafi 2002), is not particularly conversant with contexts like Tanzania where different religions, such as Christianity, Islam and Hinduism, co-exist and mix with more traditional belief systems (Ndaluka \& Wijsen 2014). In this chapter, we approach the regulating impact of religion as part of what constitutes everyday civil society, producing a public sphere wherein people organize themselves around shared issues (see Holma \& Kontinen, this volume). While much Islamic practice is concerned with "religion", with an institutional "body of beliefs and practices", it also entails "religious" experiences connected with achieving an attitude that provides faith in the possibilities of an ideal, which can likewise be displayed in the spheres of "art, science and good citizenship" (Dewey 1934, 9, 21). This Deweyan distinction between "religion" and "religious" guides our attention not primarily to the institutionally defined pillars of the Islamic faith, but to everyday faith-related practices through which certain kinds of citizenship habits, the "layered dimension that underwrites identity and thereby provide 


\section{4}

the starting points for future judgements and behaviour" (Rogers 2009, 109), are acquired.

Therefore, our interest is not in the explicitly defined virtues taught in the Qur'an - such as justice, benevolence, piety, honesty, integrity, gratitude and chastity (Halstead 2007, 284) - but those articulated by community members in relation to their everyday life. From a pragmatist perspective, these virtues do not only have a definite status granted by institutionalized dogma; they are also "tentative" attitudes or virtues that are connected both to the institution of Islam and the sphere of public life in general (Rogers 2009, 127). Moreover, while for Islam, as for other religions, morals and virtues are considered truths given by God rather than something negotiated among human beings (Halstead 2007, 283-284), it is also assumed that discovering what it means to be a human is a life-long effort of guided reflection rather than the simple adoption of certain dogmas (Ahmed 2012). We use the notion of civic virtues in a very general, everyday way in reference to "characteristics of a good citizen" that contribute to the common good (Lovett 2015). We contend that the ideals related to such characteristics are continuously learned through participation in religious communities where certain citizenship habits are acquired.

\section{Islam in Tanzania}

Although our primary interest lies in local perceptions of connections between religious morals and civic virtues, we first engage briefly with the historical context of the Islamic faith in Tanzania, and the dynamic relationship between Islam and the officially secular state. Although there is no consensus over the exact date of its arrival, history suggests that Islam has been established on the East African coast since at least the 8th and 9th centuries. On its arrival, Islam remained confined to coastal regions for some time and in the 10th century (1007 AD), the oldest still-intact building in East Africa, a functioning mosque, was built in southern Zanzibar. During the 14th century, Islam spread widely across the Indian Ocean area wherever Muslims controlled trade and established coastal settlements in South East Asia, India and East Africa (Liviga \& Tumbo-Masabo 2006; Lodhi \& Westerlund 1997).

Although Islam became familiar in the hinterland before the colonial period, due to the mediation of Swahili traders, its expansion into the East African interior came later, during the 18th and 19th centuries, facilitated by Arab trade caravans that set out from coastal cities. For example, centres such as Kondoa, Tabora and Kigoma along the old trade route were attached to Islam, despite people carrying out their local traditions in practice. The expansion of Islam continued under colonial rule in both German East Africa (1884-1914) and British Tanganyika (1914-1961), promising to restore order to a chaotic situation following the disruptions of the Maji Maji rebellion (1904-1907) and the First World War (1914-1918) 
(Loimeier 2007; Koponen 1994). After defeating the coastal Muslims, the Germans turned to them as allies in the new administration. Islam was also associated with Swahili culture, which was closely connected with coastal areas, and Germans adopted Swahili as the language of administration and built up a system of education with Swahili as the medium. They also used Swahili people (akidas and liwalis) in their direct system of colonial rule (1884-1914), hence, in a way, promoting the rapid expansion of Islam (Westerlund 1980; Iliffe 1979).

British colonial rule (1914-1961), on the other hand, prioritized local chiefs over coastal Muslims. In response, coastal Muslims participated in struggles for independence and later played a significant role in building Tanzanian socialism. At the beginning of the 1950s, the Tanganyika African Association (TAA) in Dar es Salaam had strong Muslim elements in the persons of Abdul Sykes, Ali Sykes, Dosa Aziz and others who formed an inner circle that also included non-Muslim members such as John Rupia. In 1953, however, Julius K. Nyerere was chosen to replace Abdul Sykes as chairperson of the TAA to spearhead the interests of Africans (Liviga \& Tumbo-Masabo 2006). Soon after Tanzania gained independence in 1961, President Nyerere established a nation-building programme managed under the philosophy of Ujamaa Socialism, with the vision of establishing a secular state; in fact, he discouraged religious divides among the people. In this regard, religious activity belonged to the private domain (Nyerere 1968). Nyerere pleaded for religious tolerance and the avoidance of offences against even small religious minorities, in addition to discouraging debates and research on religious matters (Liviga \& Tumbo-Masabo 2006). When he abolished the multiparty political system in 1965 , the decision was meant, among other things, to discourage any kind of divisions in Tanzanian society, including those based on religion. Although a Muslim-based political party, the All Muslim National Union of Tanganyika (AMNUT), existed both before and after independence in 1961, while the ruling political party (TANU and later CCM) emphasized that ethnic, race and religious identities had no role to play in a secular, socialist agenda of nation-building (Campbell 1999). In the same vein, during the re-establishment of a multiparty political system in 1992, legislation outlawed the registration of any political party which exhibited the features of, or associations with, any religious orientation.

Today, the majority of Muslims in Tanzania are "Africanized" and flexible about their religious habits in terms of everyday practices, such as praying, fasting and marrying across religions. In everyday life, there are no serious tensions between religions - nor between Shias and Sunnis, Tanzanian Muslims being predominantly Sunnis - with everyone "praying their own religion" alongside each other. In the public education system, religion has no significant influence: at the primary level, religious subjects are not taught officially in government schools, only in private faith-based schools; at the junior (ordinary) secondary level, religion sessions take the form of informal classes; while at the senior (advanced) level, "Islamic Knowledge" 
and "Bible Knowledge", with formal subject status, give students the opportunity to sit for a final national examination in these elective subjects. Thus, most Islamic education is concentrated in madrasa classes outside of formal education, and in parallel with the religious education delivered in the course of other Islamic religious activities, at social gatherings and within households.

\section{Learning civic virtues through Islamic practice}

This study explores the ways in which members of rural Islamic communities in Tanzania draw connections between religious morals and civic virtues; analysis is based on data drawn from individual interviews $(n=28)$ with religious teachers and community members, out of whom six were females, from three selected villages in Kondoa district, Dodoma region. Kondoa itself, the capital of the district, is positioned along the ancient caravan route; consequently, the majority of the population is traditionally of the Islamic faith. Kondoa is famous among the Muslims of the country for its high quality, Islamic education institutions. Islam is evident in the everyday life-rhythm, the way people dress, and the number of madrasas, or classrooms for Islamic education. Two of the selected villages were located relatively far from Kondoa town along a negotiable but not well-established road. The other village was nearer the town and easily reachable, mostly along a main road with a tarmac surface. Two Tanzanian researchers, a male and a female, one of whom was a Muslim himself (the first author of this chapter), conducted the interviews related to religion. The first author, and sometimes the second as well, also observed daily life in the villages and engaged in informal chats on the issue.

There were at least two mosques in each village: a BAKWATA-organized mosque, ${ }^{2}$ largely attended by relatively older members of the communities, and an Answar-Sunni mosque, which mainly attracted young Muslims. Some members of the older generation described the younger generation as aggressive in its approach and interpretation of a number of religious practices. The majority of the interviewees, many of them religious teachers and leaders, were attached to the BAKWATA mosques. Community members regularly attend prayers in the mosques, especially the five prayers a day which are the second pillar of Islam. The research team visited the villages during the month of Ramadan in 2018 when the majority of the villagers were fasting and regularly attending prayers. Nevertheless, a small group of youths and somewhat older people seemed to skip or not attend prayers at all, something described by members of the older generation as representing a decline of religious morals and ethical values. For the purposes of this chapter, observations and interviews were analysed from the point of view of community members' perceptions of how religiously-grounded morals connect with civic virtues to produce the characteristics of a "good citizen". 


\section{Islamic practices: formal and informal learning venues}

The villagers identified two basic ways of learning religious morals: first, education on Islamic principles was provided in organized classroom settings (madrasa) attended by both children and adults; second, considerable learning took place through participation in activities related to religion, ranging from attending prayers to contributing to community initiatives. Madrasa settings provided an opportunity for learning and teaching the Holy Qur'an, hadith and tafsir. In practice, learning involves reciting the Holy Qur'an and discussing the essence of respective surah and verses. As recitation takes place in Arabic, teaching starts with the basics in order to introduce an elementary understanding of the language among participants. Hadith and tafsir are generally about making sense of the Holy Qur'an through the contextualized meaning of the words of God (sacred hadith) and detailed deeds: that is, the teachings, statements and actions of Prophet Muhammad, peace be upon him (noble hadith); tafsir goes further to translate the teachings of the Holy Qur'an from Arabic to Swahili.

Educational activities conducted in madrasa settings, among both schoolaged children and adults, play an important role in cultivating an Islamic worldview. Class sessions are scheduled so that they do not compromise other routine activities. For example, children in groups that include both genders attend madrasa from around 4:00 to 6:00 p.m. during the weekdays after their formal education, and for longer periods of time at weekends. Adult students, in groups separated by gender, attend madrasa sessions after completion of their duties in farming, small business management and domestic activities. While the adult men had the opportunity to extend their classes until around 8:00 p.m., adult women often left during magharib ${ }^{3}$ as they had to attend to their families and household responsibilities.

While this difference can be seen as a practical matter, it also essentially relates to the gendered difference in the virtues to which people aspire. Religious morals as social norms assigned family care and household responsibilities to women ("good wives") rather than their male counterparts ("good husbands"), socially constructed, gender-divided roles that have been seen to reflect inequality in regard to the public space provided (Hakura et al. 2016; Strachan 2015). In a similar vein, both male and female interviewees indicated that control over behaviour related to dressing and social interactions was stricter for girls than for boys. Nevertheless, for adult women, even with the time limits, madrasa sessions also served as public spaces, as platforms for sharing experiences of parental roles and other issues, as well as providing opportunities to participate in established income-generating groups. As Loimeier (2007) observes, in rural areas religious education provides important space for such interaction on shared issues, as other events, such as NGO seminars, are rare compared to urban settings.

In addition to madrasa settings, the inculcation of religious morals took place in many other daily activities and community gatherings. In the 
interviews, religious leaders and teachers emphasized that the five pillars of Islam - shahada (declaration of faith), salah (everyday obligatory prayers), zakat (compulsory giving), sawm (fasting in the holy month of Ramadan) and hajj (pilgrimage to Mecca) - provide a profound cognizance, helping believers to accept, commit and adhere to the faith. They further explained that these formed the basis for daily activities and that each of the five pillars complements the others, as every Muslim believer must practice all of them, except for hajj, which requires financial capacity. For example, the interviewees placed importance on regular attendance in mosques to offer the five obligatory prayers, fulfilling their compulsory giving, taking part in voluntary community activities and contributing in cash and in kind to any community request. Involvement in Islamic social gatherings - either in joys (Eid-al Fitr, Eid al-Hajj and Mawlid al-Nabi) ${ }^{4}$ or in sorrows (burial ceremonies) - were also important. In addition, related religious projects, such as the cleaning, construction and renovation of mosques and madrasas, included religious teaching to remind members of their primary purpose of existence from an Islamic point of view. Indeed, religious leaders stated that gatherings such as these also socialize community members by encouraging certain types of "good behaviour" while assisting to transform, revitalize, redirect or reshape the patterns of those which are not appreciated. Therefore, even informal gatherings contributed to the continuous construction of an ideal member of a Muslim community. For instance, one female villager summarized the significance of participation as follows:

Participation in religious activities makes me feel liberated. This is because religious morals can counteract some mental factors that lead to bad practices such as greed, hatred and delusion.

Thus, the basic idea that participation in religious activities provides spaces in which to connect with God also supports a holistic understanding of the distinction between good and bad in both spiritual and very practical conduct in any sphere of life.

\section{Identifying religiously grounded morals}

Examining community conceptualizations of religiously grounded morals raises a more general question concerning the ways in which Islam shapes the public sphere - from everyday life to the national level - in engagement with a secular state (Turam 2004). Halstead $(2007,287)$ suggests that in Islam morality largely falls into three categories: first, obligations and duties; second, values and manners related to good upbringing; third, personal qualities demonstrated in everyday life. While all these elements receive their specific meaning in Islam as an institutionalized religion, they can, nevertheless, be conceived of in terms of more general civic virtues, as part of the good conduct of a human being as a member of a community (Dewey 1934). 
In our analysis, we focused on the kinds of morals and virtues to be exercised in everyday life which were identified by the interviewees.

Top of the list was helping and giving charity to the poor, helpless and disadvantaged people in the community. Interview narratives highlighted that religious teachings call for the provision of care and love for one another, especially the sick and deprived in the community. Villagers expounded further that, in addition to allowing recipients to meet their needs, helping and giving charity is deeply rewarding in the Islamic faith; in whatever form it may take, helping others is crucial, not only for the wellbeing of the needy, but also for the ultimate happiness of the entire community. As one interviewee summarized:

In our faith, it is encouraged to give charity because it shows how goodhearted one is. Therefore, one need not be super rich in order to give charity. Rather, the motive should be the need to help the needy.

Cooperating with, and showing kindness, to the rest of the community - both in joys and in sorrows - emerged as a second form of religiously grounded behaviour that distinguishes who may be identified as a religious person. Interviewees first noted that religious teachings require them to demonstrate generosity to everyone, thereby further highlighting that, since they live a collective kind of life, friendly relations are necessary. From the perspective of the villagers, the Islamic faith teaches them to practice kind and gentle behaviour and offer mutual support to other community members. As summarized by an interviewee:

In our daily life, problems find anyone, anytime. Therefore, one has to show humanity by comforting and supporting those in such situations. In fact, you never know, the same may happen to you.

Furthermore, community members associated religious people with characteristics such as forgiveness and keeping promises, thus underscoring that in the Islamic faith, human beings are not "perfect creatures", and can make mistakes that negatively affect others. On this basis, villagers expressed the importance of forgiveness as a way of appreciating "human weaknesses", while creating harmonious relations in the community. Meanwhile, they described a promise as moral duty that requires an individual to do whatever has been said would be done. As a moral duty villagers felt that a promise carries the kind of obligation that does not need legal enforcement but rather, is fulfilled due to considerations of right and wrong within the Islamic faith. On the importance of forgiveness, one religious leader noted:

In addition to bringing harmony, another benefit of forgiveness is the reward that one receives from God. Therefore, we encourage people to 
forgive one another because if you do not forgive, the same will be reciprocated to you on Judgement Day.

In addition, interviewees pinpointed that tolerance was an important attribute among religious people, elucidating that Islamic teachings forbade them from being judgmental of others. They further stressed that the beauty of being tolerant to each other is that it produces a better community, characterized by love and care for everyone. Tolerance makes people remain humble and capable of controlling their emotions, thereby enabling them to accommodate the opinions and ideas of others. In this regard, it was claimed that tolerant people respect everyone, as demonstrated in the way that communal life brings people together from different ethnic and religious backgrounds. As one interviewee remarked, "Without tolerance, there is no harmony."

Similarly, interviewees mentioned that religious people must demonstrate decency and truthfulness in their ideas and practices, elaborating further that religious teachings forbid qualities associated with deceit; on the contrary, religious morals always promote telling the truth. Villagers noted that it was considered good behaviour in their community to demonstrate a high standard of honesty, both in private and in public life, with one interviewee observing, "It is only by possessing a reputation for telling the truth that the rest of the community can respect you." Decency and truthfulness are thus considered a way of showing respect for others, while expecting reciprocity in return.

\section{Drawing connections between religious morals and civic virtues}

When describing and identifying religious morals, interviewees also reflected on the connections between these morals and characteristics of good citizenship, or civic virtues. They understood civic virtues to refer to the abilities that enable individual community members effectively to undertake their responsibilities at the household level and in the community. Therefore, developing certain habits by participating in religious activities contributes to cultivating a "good citizen" with the behavioural patterns required for a well-functioning civic and political life. The link between religious morals and civic virtues appeared quite self-evident as the interviewees were largely of the opinion that Islamic religion was a way of life in their community. They further explained that Islamic religious morals offer mental and spiritual guidance that resonates with other spheres of human activities, including that of the state and politics. As a religious leader said:

Islamic religious values forbid behaviours related to theft, corruption, drug abuse, telling lies, and much more, while the government does the same in social and political life. Therefore, if you ask me, a good religious believer is also a good citizen. 
Almost all the interviewees, especially religious leaders, stressed that religious morals remind people of the difference between good and evil in the context of Islam and, thus, in life in general. They further emphasized that religious morals do not only guide the good conduct of individuals, but also define the kind of society that will produce good members. However, interestingly, many interviewees did not only mention Islamic morals, but were of the opinion that religious morals in general establish solid grounds for good citizenship. As a female interviewee described:

In Islam there is love, in Christianity there is love. The Christians worship, the Muslims worship. You see, it is the same. I cannot say about other religions as I do not know then based on my experience (...) We depend on each other, we help each other, and thus, we bring development together.

Above all, villagers articulated that people with religious morals are motivated to engage in activities that promote the wellbeing of the community. Yet they also acknowledged that a combination of factors influence community wellbeing that includes social, cultural, environmental, economic and political conditions, in which all community members have the role to play. Villagers were of the opinion that religious morals hindered passiveness, and thus supported being active in joint initiatives in the community. Likewise, interviewees articulated a view according to which "good citizens" should know what the community expects from them and, thus, can act proactively. These articulated expectations were often gendered. For example, interviewees noted that religious morals make women perform their roles as mothers and family caretakers to the full, while requiring their husbands to ensure the social and economic wellbeing of the family and society at large. Villagers highlighted that people with religious morals habitually feel a sense of responsibility and demonstrate control over their deeds, adding that they greatly appreciate individuals who take the required action or complete tasks without any external pressure.

Furthermore, according to the interviewees' perspectives, a person with religious morals takes all the necessary initiatives to avoid corrupt practices, thereby making it clear that corruption in any form is unacceptable, both in religious teachings and in civic life. Indeed, villagers emphasized that corrupt practices destroy ethical values and justice, and in the end can destabilize society. The understanding of good civic habits was thereby linked to individual behaviour that upholds justice and avoids corrupt practice in the family, workplace, community and the nation at large. In this respect, interviewees expressed the need for both men and women to demonstrate a sense of uprightness in the face of corrupt practices in different roles embedded in the family and society. Villagers observed that, because of the harm that corruption can bring to a community, it is the moral and civic duty of every community member to fight it, directly or indirectly. As one interviewee stated: 
Corruption affects us all. It is not fair to stay aside and keep lamenting on gross misconduct in political processes, especially when one has an opportunity to take part in changing the situation. Before God, everyone will have to account for what you have done to change the situation, given the little opportunity you had.

In addition, interviewees appreciated religious morals for their role in moulding community members to reject cruelty, violence and abuse. According to them, a good community member will always avoid practices that dehumanize fellow members or human beings at large. They further noted that it is morally wrong, according to their faith, for an individual or group of people to harm someone else's life or cause suffering to others. With this in mind, some people in the villages took part in the campaigns against killing people with albinism and preventing suffering caused by violence against women and children. In line with this, villagers were of the opinion that a good citizen always refrains from cultural practices that in any way encourage or lead to cruelty, violence or abuse against fellow community members. They emphasized that it is the responsibility of every citizen to ensure that all community members enjoy their basic freedoms and that the entire society, including women and children, lives in a peaceful and harmonious atmosphere.

Similarly, villagers were of the view that religious morals cultivate lawabiding behaviours among community members. In their understanding, each society has its own ways of doing things, often enunciated in the different laws, regulations and procedures that should be followed. Interviewees were of the opinion that it is morally unbecoming to disobey the laws of society. For them, discipline starts at the family level where children must obey their parents, wives respect their husbands and husbands reciprocate this respect by meeting their responsibilities, hence scaled up to the society level. In this respect, villagers noted that a good citizen obeys the established laws and regulations generated in cultural, religious and political arenas. Therefore, a good member of their community has to ensure that he/she fully understands the laws and follows them accordingly.

Moreover, interviewees pointed out that being hardworking and economically self-sufficient are additional qualities of "a good community member". In their opinion, religious morals teach people to work in order to earn a living by lawful means, thus holding the view that individuals with civic virtues are habitually people who work hard in order earn their livings lawfully. This implies that civic virtues encourage economic independence at the individual level and thence the entire community, something illustrated by the incomegenerating activities established by women's religious groups, such as local saving schemes in order to help build the economic strength of their families. Indeed, it was a civic duty for a good citizen to be economically self-sufficient in order to provide for his/her family, and ultimately contribute to the economy of the community. This implies that religious morals provide behavioural 
guidelines for organizing the production of goods and services and exchange, distribution, consumption, profit making and price setting. In this regard, one religious leader summarized as follows:

We encourage community members to engage in lawful economic activities. It is a good habit to be independent because our religion forbids the behaviour of begging, especially for energetic people who have no disability that inhibits them from engaging in productive activities. We also discourage people from orienting themselves around super profit making because it is not fair for one person to be super rich at the expense of others. We often tell our business persons to be considerate to their customers, most of whom are poor community members.

Villagers also noted that religious morals cultivate peace and order in their community because they reinforce people's respect for the legitimate authorities, including religious, traditional and village governments. In this understanding, villagers considered respect for legitimate authority one of the "good behaviours" in their communities. In addition to maintaining social order, interviewees associated respect for the authorities with the need to ensure political harmony; they perceived the authorities to be promoters of common goals, such as equality and justice, meanwhile appreciating the role of religious leaders in strengthening unity and togetherness through their spiritual teachings. Village government leaders oftentimes gave directives regarding various civic rights and duties, such as those related to political elections and participation in other decision-making processes concerned with social and economic benefits. In this regard, a "good citizen" follows sets of rules recognized as legitimate and operational in the community. These rules were considered societal values and used to guide the behaviour and actions of community members, as one interviewee summarized:

A good person believes in God, and God wants his people to observe good deeds such as justice, forgiveness and to repel evil with what is better. If you ask, religious and political authorities emphasize the same things. It is misbehaviour if we do not respect them.

Religious morals seemed to motivate community members to work together not only towards the attainment of religious objectives, but also in addressing social goals. Villagers observed that good citizens voluntarily participate in collective activities including community projects that require the attention of all village members. They favoured the essence of community spirit that enhances the sense of togetherness in their religious faith and other social practices. In this respect, women gave examples of performing cleaning operations in the mosques and cooking at social gatherings such as burial and marriage ceremonies. For their part, men cited examples of participating in manual work such as the construction and renovation of mosques as well as 


\section{Nguyahambi and Kontinen}

other community projects that required collective action. From the perspective of the community members, there was little separation between individuals, religion and society. Interviewees stressed how religious morals played a big role in preparing community members for interactive participation in religious and non-religious activities.

Islamic morals guide my way of life. They teach me how to talk to others, how to dress, love and care for my family, and generally in all my practices regarding how to relate to my fellow Muslims and non-Muslim community members.

This quote also illustrates that members of the Islamic community acknowledged the presence of other religious groups in their midst, and promoted mutual acceptance and tolerance among different religious positions.

\section{Conclusion}

In this chapter we have reflected on the kinds of citizenship habits potentially acquired by participation in Islamic practices in rural communities in Tanzania. Our analysis has concentrated on identifying the ways in which community members articulated connections between religious morals and civic virtues, especially focusing on the positive characteristics of a "good citizen" as understood by community members, based on their everyday experiences. Thus, in this chapter, we did not engage with a holistic analysis of connections between the Islamic faith and citizenship in general, neither were we able to capture differences and discrepancies within the Islamic community. Insights from community members in this chapter hold that "a good believer is a good citizen" because faith influences all spheres of daily life. The characteristics of being a good citizen articulated included being able to distinguish between good and evil, avoiding corrupt practices, being aware of specific rights and responsibilities, rejecting violence and abuse, being lawabiding and economically self-sufficient, cultivating peace and harmony and respecting the authorities.

These diverse civic virtues reflect certain kinds of citizenship habits acquired through participation in faith-related practices. Primarily, the citizenship habits identified are social, reflecting the argument that in Islam, "goodness is not an individual matter" (Halstead 2007, 289). It was clear that accounts of civic virtues were related to the kinds of "good people" and "good community" desired. An individual is supposed to be a responsible and functional member of his/her community: self-reliant but not dismissive of other members. The idea of a good citizen who contributes but does not benefit from others was related to the need to be economically self-reliant and hardworking, to participate voluntarily in community initiatives, help those in less privileged positions and be against violence and abuse. In this sense, Islamic morals reflected a religious attitude connected to hope and the 
struggle for something better (Dewey 1934) and, thus, provided criteria for judging good behaviour in the present life as well (Rogers 2009). Additionally, as is central to any religious thinking, being a good citizen was not only about the present life, but also about ensuring a good life after death, in the afterlife, and conducting good behaviour in God's sight.

The good citizen's characteristics of cultivating peace, being law-abiding and respecting all kinds of authority also reflected "harmony-seeking" citizenship habits. The importance of harmony and peace was shown not only in accounts related to the Islamic community, but in reference to the need to live in peace with community members of different religions and a variety of ethnic backgrounds. Harmonious citizenship habits included respect for the authorities, thus partly contrasting with the idea that the active citizen is one who engages with the authorities to claim his/her rights (Gaventa \& Barrett 2012). During our research, we did not receive any accounts of contestations with, for instance, corrupt authorities; however, the narratives indicated that, instead of open confrontation, people gradually cease to respect authorities they consider are misbehaving. Moreover, the notion of harmony tended to maintain rather than contest existing explicit status differences: for instance, in regard to the relationship between ordinary believers and religious leaders, teachers and students, and between women and men.

While many of the characteristics of a good citizen were associated with Islamic morals, they also reflect Tanzania's historical and political contexts. First, the importance of community participation in rural settings speaks not only to the Islamic faith but also to its prevalence in local governance since the early drive for independence (see Nguyahambi et al., this volume). Second, the ways in which community members spoke about the desirability of harmony between members of different religions echoed the ideology of the secular state, dating back to Nyerere's (1968) times. The interviewees explicitly cited common slogans such as "the state does not have a religion; individuals have", or, "you should not mix religion with politics". For the members of the Islamic community in Tanzania more broadly, good citizenship is not about promoting their religion in the public arena but, rather, being a good member of a pluralistic nation in which faith-related practices provide significant spaces of belonging and of identity.

Such community-centred and harmony-seeking citizenship habits could potentially function as a fruitful starting point for any civil society initiative with the goal of strengthening citizenship. This would, however, require acknowledgement of the intertwined nature of religion and civic life, and the realization that undertaking activities that potentially jeopardize harmony or diminish the power of the traditional authorities might be almost unimaginable for ordinary community members, not only because of the need to maintain the good life in the present, but also to ensure a good afterlife. Thus, the implication for the concept of civil society is that ordering and organization on religious principles constitutes a significant part of public and civic life in general, from particular perspectives which are not always conversant with the liberal view of the citizen. 


\section{Notes}

1 The 1967 census was the last one to categorize people based on spiritual beliefs (Heilman \& Kaiser 2002).

2 BAKWATA is an abbreviation for Baraza Kuu la Waislamu Tanzania literally meaning the National Muslim Council of Tanzania. It was founded and registered in 1968 and is a well-established, faith-based Islamic organization, with branch offices all over the country and networks from national to the grassroots levels. As the official Muslim council, recognized by the government, BAKWATA is the target of resistance from relatively aggressive Muslims. often referred to as Answar Sunni, many of whom are young. The misunderstanding between the two because Answar Sunni considers BAKWATA an organization that the government uses to control Muslims instead of dealing with their development concerns.

3 Magharib denotes both prayer time and a prayer itself, which is conducted just after sunset. It is the fourth of five obligatory daily prayers performed by practicing Muslims. In Kondoa and large part of Tanzania, magharib occurs around 6:00-7:00 pm East African time.

4 Eid-al Fitr, Eid al-Hajj and Mawlid al-Nabi are Muslim religious festivals recognized officially as public holidays in Tanzania. Eid-al Fitr takes place on the first and only day in the month of Shawwal during which Muslims are not permitted to fast. The holiday celebrates the conclusion of the 29 or 30 days of dawn-to-sunset fasting during the entire month of Ramadan. Eid al-Hajj takes place on the day of Arafah, the second day of pilgrimage rituals, which marks the conclusion of the event of the annual Islamic pilgrimage to Mecca. Mawlid al-Nabi is celebrated to mark the birth of Prophet Muhammad (peace be upon him) in around 570 AD.

\section{References}

Ahmed, F. (2012). 'Tarbiyah' for 'shakhsiyah': Seeling out culturally coherent pedagogy for Muslim children in Britain. Compare: A Journal of Comparative and International Education, 42(5), 725-749.

Bompani, B. \& Frahm-Arp, M. (Eds.). (2010). Development and politics from below: Exploring religious spaces in the African state. London: Palgrave Macmillan.

Bompani, B. \& Valois, C. (2017). Christian citizens and the moral regeneration of the African state. London: Routledge.

Campbell, J. (1999). Nationalism, ethnicity and religion: Fundamental conflicts and the politics of identity in Tanzania. Nations and Nationalism, 5(1), 105-125.

Chambers, S. \& Kymlicka, W. (Eds.). (2002). Alternative conceptions of civil society. Princeton, NJ: Princeton University Press.

Dewey, J. (1934). A common faith. New Haven, CT: Yale University Press.

Elshtain, J.B. (2009). Religion and democracy. Journal of Democracy, 20(2), 5-17.

Englund, H. (2011). Christianity and public culture in Africa. Athens: Ohio University Press.

Gaventa, J. \& Barrett, G. (2012). Mapping the outcomes of citizen engagement. World Development, 40(12), 2399-2410.

Habermas, J. (2006). Religion in the public sphere. European Journal of Philosophy, 14(1), $1-25$.

Hakura, D., Hussain, M., Newiak, M., Thakoor, V. \& Yang, F. (2016). Inequality, gender gaps and economic growth: Comparative evidence for sub-Saharan Africa (IMF Working Paper). International Monetary Fund. Retrieved from www.imf.org/ external/pubs/ft/wp/2016/wp16111.pdf 
Halstead, J.M. (2007). Islamic values: a distinctive framework for moral education? Journal of Modern Education, 36(3), 283-296.

Hanafi, H. (2002). Alternative conceptions of civil society: A reflective Islamic approach. In S. Chambers \& W. Kymlicka (Eds.). Alternative conceptions of civil society (pp. 171-189). Princeton, NJ: Princeton University Press.

Heilman, E.B. \& Kaiser, P.J. (2002). Religion, identity and politics in Tanzania. Third World Quarterly, 23(4), 691-709.

Holma, K. \& Kontinen, T. (2019). Practices and habits of citizenship and learning. In this volume.

Iliffe, J. (1979). A modern history of Tanganyika. Cambridge: Cambridge University Press.

Jones, B. (2012). Pentecostalism, development NGOs and meaning in eastern Uganda. In D. Freeman (Ed.). Pentecostalism and development: Churches, NGOs and social change in Africa (pp. 181-202). Hampshire: Palgrave Macmillan.

Kfir, I. (2008). Islamic radicalism in East Africa: Is there a cause for concern? Studies in Conflict and Terrorism, 31(9), 829-855.

Koponen, J. (1994). Development for exploitation: German colonial policies in mainland Tanzania, 1884-1914. Finnish Historical Society: Studia Historica 49. Helsinki/ Hamburg: Lit Verlag.

Lewis, D. (2002). Civil society in African contexts: Reflections on the usefulness of a concept. Development and Change, 33(4), 569-586.

Liviga, A. \& Tumbo-Masabo, Z. (2006). Muslims in Tanzania: Quest for an equal footing. In R.S. Mukandala (Ed.). Justice, rights and worship- religion and politics in Tanzania (pp. 129-164). Dar es Salaam: University of Dar es Salaam, REDET Department of Political Science and public Administration.

Lodhi, A. \& Westerlund, D. (1997). African Islam in Tanzania. Retrieved from www. islamtanzania.org/articles/islam $2 . h t m$

Loimeier, R. (2007). Perceptions of marginalization: Muslim in contemporary Tanzania. In B. Soares \& R. Otayek (Eds.). Islam and Muslim politics in Africa (pp. 137156). New York: Palgrave Macmillan.

Lovett, F. (2015). Civic virtue. In M.T. Gibbons (Ed.). The encyclopedia of political thought (pp. 1-10). John Wiley \& Sons. Retrieved from https://onlinelibrary.wiley. com/doi/10.1002/9781118474396.wbept0147

Manglos, N.D. \& Weinreb, A.A. (2013). Religion and interest in politics in subSaharan Africa. Social Forces, 92(1), 195-219.

Ndaluka, T. \& Wijsen, F. (Eds.). (2014). Religion and state in Tanzania revisited: Reflections of 50 years of independence. Zürich: LIT Verlag.

Nguyahambi, A.M., Chang'a, H.H., Matunga, B.N., Kilonzo, R.G. \& Kontinen, T. (2019). Contextualizing citizenship in Tanzania. In this volume.

Njozi, H.M. (2000). Mwembechai killings and the political future of Tanzania. Ottawa, ON: Globalink Communication.

Nyerere, J.K. (1968). Freedom and socialism. Dar es Salaam: Oxford University Press.

Robins, S., Cornwall, A. \& von Lieres, B. (2008). Rethinking 'citizenship' in the postcolony. Third World Quarterly, 29(6), 1069-1086.

Rogers, M.L. (2009). The undiscovered Dewey: Religion, morality, and the ethos of democracy. New York: Columbia University Press.

Sapir, G. \& Statman, D. (2012). Religious argument in the public sphere. Journal of Law, Religion and State, 1(3), 242-257.

Stith, C.R. (2010). Radical Islam in East Africa. The Annals of the American Academy, $632,55-66$. 
138 Nguyahambi and Kontinen

Stitzlein, S.M. (2014). Habits of democracy: A Deweyan approach to citizenship education in America today. Education and Culture, 30(2), 61-85.

Strachan, A.L. (2015). Women in politics and the public sector in Tanzania. Birmingham: University of Birmingham.

Turam, B. (2004). The politics of engagement between Islam and the secular state. British Journal of Sociology, 55(2), 259-281.

Westerlund, D. (1980). Ujamaa na dini: A study of some aspects of society and religion in Tanzania, 1961-1977. Stockholm: Almqvist \& Wiksell International. 


\title{
10 Habits of contributing citizenship Self-help groups in rural Tanzania
}

\author{
Rehema G. Kilonzo, Benta N. Matunga, Haji H. \\ Chang'a and Tiina Kontinen ${ }^{1}$
}

\section{Introduction}

In this chapter, we approach self-help groups in rural Tanzania as loci of specific practices and reflect on the kinds of citizenship habits that are acquired through participation in them (Holma \& Kontinen, this volume). By self-help groups, we refer to locally organized groups established to address the needs and challenges of their members. They provide significant fora for people's own organizing and voluntary participation (Rodima-Taylor 2014), and play an important role in economic, social, political and psychological empowerment in the countries of the Global South (Brody et al. 2016). Our interest in self-help groups emerged from the intersection of three main elements. First, our exploratory study of the everyday practices in which people participate outside their immediate households - conducted in selected villages in Kondoa District (Nguyahambi et al., 2017.) - indicated that self-help groups were among the most common, especially for women. Second, development research suggests that in African civil society self-help groups are among the most prevalent organizational forms (Lewis 2002; Rodima-Taylor 2013), while membership-based organizations are considered essential in promoting local development (Banks et al. 2015, 709); importantly, they also offer examples of local associations that function as "schools of democracy" (Gaventa \& Barrett 2012, 2406). Third, from the pragmatist point of view prevalent in this book, self-help groups provide concrete examples of a specific form of associated life (Dewey 1922/2012), and of a general human activeness in addressing shared problems.

Development research suggests particular connections between participation in local groups and associations, and citizenship. For example, Merrifield (2002) argues that local groups provide opportunities to access important knowledge, abilities and dispositions related to the exercise of citizenship, and Gaventa and Barrett $(2012,2402)$ see local associations as both a means to solve problems and to "construct citizenship" through increased awareness, strengthened self-identity and thickened social networks. Local groups are seen to provide the skills of associational participation that build the "political capabilities" of their members (King 2015, 754), and also to work as 
potential stepping stones towards political empowerment, even if they are not explicitly "political acts" (Brody et al. 2017, 18). They are also regarded as providing platforms for the acquisition of competencies and skills that might be transferred to other, more "political" arenas of emerging citizenship, such as demanding a responsive and accountable state (Gaventa \& Barrett, 2012, 2402). Generally, self-help groups are considered a means to achieving a certain kind of political stance: active citizenship that includes engagement with the state and claiming rights in diverse arenas. In contrast, from an anthropological perspective, Englund (2004, 2) suggests that, instead of starting with an abstract idea of "rights", we should pay attention to diverse arenas of "intermediate solidarities". In line with this, Rodima-Taylor $(2013,77)$ suggests that self-help groups constitute such an arena; she also notes that the material / social connectedness with other people that is one of their features takes particular forms, including members' expectations and obligations. In the same vein, our primary interest lies in the practices inherent to self-help groups and the citizenship habits they produce.

We define citizenship habits as dispositions to interact, organize and think jointly with others in situations where shared problems are addressed and common good promoted. Our usage of the notion of habit derives from John Dewey's $(1922 / 2012,20)$ definition as "acquired predispositions to ways or modes of response, not to particular acts". Consequently, in our usage, habits do not refer directly to the activities the self-help groups undertake, such as meetings, loans, agricultural work or elections, but the dispositions to think, to act and to respond which members acquire as a result of their experiences in these particular groups. According to Dewey (ibid., 11), habits in general are formed through social conduct with the support of "environing conditions" such as a specific group of fellow (wo)men. We understand self-help groups as providing such conditions. Moreover, we scrutinize citizenship habits that, according to Stitzlein $(2014,63)$, develop in social groups through interaction with others and the world. We contend that self-help groups provide spaces for this kind of interaction in which members gradually acquire certain citizenship habits.

The nature of the latter depends on what takes place in a specific social group: the modes of interacting with others in the group, of building social knowledge, of solving problems together and of upholding a common good (Stitzlein 2014, 66). Consequently, in order to be able to reflect on the citizenship habits acquired, we focus on the question of the practices self-help groups engender, approaching the issue via the experiences and accounts narrated in interviews with members of nine self-help groups in three rural villages in Kondoa District, Tanzania, in June-July 2018. In our analysis, we focus on three main themes related to the characteristics of practices: What kinds of shared problems do self-help groups address and how? How is the interaction within the group organized and governed? Who participates in the self-help groups? In the course of analysis, we constantly encountered a theme of contribution. The members of self-help groups reflected on what 
kinds of contribution (mchango) the group makes to their own well-being, the different ways in which they were able and expected to contribute (kuchangia), and what kinds of rules governed different contributions. Consequently, we suggest that a habit of contributing citizenship is acquired through participating in these entities.

In what follows we briefly discuss the general role and practices of self-help groups in the context of development and Tanzania before presenting the characteristics of these practices as experienced and described by the participants. We then reflect on the citizenship habits that are acquired through participation in self-help groups, elaborating on our notion of contributing citizenship and discussing it in connection with the ideals of active citizenship.

\section{Self-help groups as practices in the context of development in Tanzania}

Self-help groups have long occupied a central role in international development - especially in regard to women's empowerment (Anand 2002; Bouman 1995; Brody et al. 2016) - and the significance of group formation in addressing poverty has likewise been previously accepted (Thorp et al. 2005). Different kinds of mutual-help associations have multiple purposes: facilitating political alliances, providing psychological support and offering access to new sources of information and collaboration partners, among others (RodimaTaylor 2014, 562). In development practice, mutual-help associations and savings and credit groups have received extensive attention as a means of providing financial inclusion for the less privileged (Le Polain et al. 2018). Group models, such as Village Savings and Loan Associations (VSLA), introduced by international NGOs, are widespread in Sub-Saharan Africa (Allen 2006; Green 2019) where, in addition to enabling economic inclusion and poverty reduction, they have been seen as potential schools of democracy (Gaventa \& Barrett 2012) and spaces for social, political and psychological empowerment (Brody et al. 2016).

In Tanzania, the idea of self-help groups is neither new nor even initially introduced by international development actors; indeed, customary mutual help practices have existed since pre-colonial times (Rodima-Taylor 2014). There are long traditions of mobilizing on the basis of mutual help, in agricultural activities, for example, or when arranging events such as weddings, anniversaries and funerals (Tripp 1994); these are still prevalent today, often requiring substantial financial contributions in addition to provision of voluntary labour (Dill 2010). Moreover, at least since the 1950s, locally organized, small saving groups (upatu) have been created, which grew in number in the mid-1980s along with urbanization (Tripp 1994). Since the mid-1990s, more formalized, registered, community-based organizations (CBOs) and non-governmental organizations (NGOs) have become more prevalent (Dill, 2010), partly due to the influence of the international development community, which extensively funds NGOs under the banner of strengthening civil society. 
In Tanzania, the "allegedly customary" ways of sharing and mutual help were also adopted by post-colonial, socialist governance (Rodima-Taylor 2014, 568), and articulated in the post-independence ideologies of Ujamaa and self-reliance formulated by the first president, Julius K. Nyerere (Ibhawoh \& Dibua 2003). The subsequent creation of Ujamaa villages called for the participation and hard work of all to increase productivity and improve livelihoods (Sheikheldin 2015); the system also insisted that people live peacefully together, and demanded that individuals, all considered equal, become persons through the medium of community (Hunter 2008). It has been argued that President Nyerere's philosophy failed from an economic perspective (Ibhawoh \& Dibua 2003) and, at times, the noble political ideals were implemented through forced resettlements (Rodima-Taylor 2014) and/or the imposition of obligatory participation (Schneider 2004). Nonetheless, the legacy of his policies can be seen in the maintenance of political stability and the achievement of a substantial degree of harmony between the country's ethnic groups, which number more than a hundred (Ibhawoh \& Dibua 2003; Rodima-Taylor 2014), as well as in the prevailing contemporary discourse of development, self-reliance and citizens' participation (Nguyahambi et al., this volume). More recent development policies in Tanzania have emphasized - at least in rhetoric - the significance of groups and the need to allocate them public funding through local government authorities (LGAs), especially groups of women, people with disabilities and youth.

\section{What kinds of shared problems do self-help groups address and how?}

In this section, we describe issues related to the common good and shared problems which groups address, which, in turn, influence the citizenship habits acquired (Stitzlein 2014). Among the nine self-help groups from three villages participating in the study, their type, scope and functions varied from very small, informal neighbourhood mutual help groups (vikundi vya kusaidiana) to more formal organizations with up to 30 members engaged in joint economic activities, such as cultivating and marketing agricultural products or savings and credit schemes. All groups were self-organized and designed to solve various problems experienced by their members. Thus, they were not originally established in the framework of an externally funded development initiative, although some of them had received training from various NGOs at some point. As the example of the Upendo group illustrates:

We started as an informal self-help group with 20 individuals, meeting every week on Sunday, contributing Tsh 10,000 (app. 3.8 euros) each. After 20 weeks of rotation, every one of us was able to receive Tsh. 200,000 (app. 76 euros) each to solve an immediate problem such as paying school fees or as capital to start or expand a small business with different items. Later we learned about the Village Community Bank 
(VICOBA) model with savings and borrowing activities. This [offered a] low interest rate for members with minimum contributions. We managed to network with one of the VICOBA facilitators who helped us to establish a formalized savings and credit group of 30 members contributing a minimum of Tsh. 6,000 every week. We prepared a constitution [containing] explicit rules and regulations concerning the purposes of borrowing money (lengo la mkopo), and we make a follow-up to make sure that the money borrowed is used for the intended purpose. We also managed to register our group with the village government level.

Self-help groups were typically formed to address immediate and practical problems experienced by members struggling to solve them within their household means. For instance, groups responded to sudden challenges such as a death in a member's family by providing cash and labour. In the saving and lending groups, members had borrowed money for purposes that included paying their children's school fees, building better houses, purchasing new mattresses, constructing improved toilets in their households, expanding farming activities and engaging in small entrepreneurial activity such as running a village café. Jitegemee, for example, is a group that addresses problems connected with the quality of agricultural products. It began in 2001 with two individuals who produced onion and tomato seeds; two years later two more members were welcomed who grew maize seeds; in 2006 these were joined by two cowpea producers; in 2008 two more focusing on sunflower seeds and so on, until the current complement of 15 members, all of whom are preoccupied with growing vegetables. Each member is responsible for her/his own gardening, but the group helps each other during planting, weeding and harvesting. The financial and social aspects also intertwine when members buy each other's products especially for social functions, such as weddings and funerals. These experiences, and many others like them, show what while the groups initially and primarily address problems related to income and livelihood, they also provide members with an important forum of social belonging.

While the self-help groups in the study were locally organized, most of them also looked to external sources for financial, material or training support, which was often provided under the banner of development (maendeleo) (Green 2012b). For instance, funding by government bodies, banks, NGOs or microfinance institutions is granted to groups rather than individuals. Moreover, the groups should have established and reliable practices such as registration, a constitution and a bank account with identified signatories and regular transactions. At times, the search for external funding constituted the main shared problem, guiding the rearrangement of group practices in order to meet funders' demands in regard to legitimate civil society organizations (Green, ibid.). Nevertheless, as interviews with the self-help groups demonstrated, not all groups received the loans they expected, and they continued to solve their problems by lending money among their members. As the group leader of Ari Kasi Nguvu Mpya explained: 
We managed to open a bank account at NMB bank at Kondoa with the aim of obtaining a loan from supporters to expand our economic activities, such as buying a posho [maize] mill machine to cater for our needs. However, we have not received any loan from any supporter including the government. Now we are engaged with keeping goats for income and other needs.

Self-help groups also addressed shortages experienced by village leadership and wider village communities. For instance, when village leaders needed assistance in showing hospitality to visitors, the groups contributed cash, food, song, dance and testimonies of successful development initiatives. The active groups and their innovative ideas brought credit to the village leaders for the good performance of their roles in the eyes of visiting authorities and leaders at higher levels. All the groups interviewed had participated in one way or another in village government activities related to Mwenge wa Uhuru (Torch of Freedom) $)^{2}$ by providing material support such as utensils, cash and traditional dance, with songs carrying messages related to development (maendeleo). Groups frequently participated in community activities such as planting trees, improving school buildings, keeping the environment around health centres clean and protecting village water sources. Additionally, groups contributed by formulating innovative ideas for community development and sharing them with the village government and, later, the village assembly. If accepted for implementation, the groups mobilized other community members (kuhamasisha wengine). For instance, as an interviewee from Neema A group explained:

They are being sensitized. I was educated when I went for training; it is not that the training is all about buying shares, it has many things, for instance loss of harvest, we learned about all these. We were told how to use metal silos and treated bags for storing food. We were taught by HELVETAS (a Swiss NGO). When I started to sensitize people, they all started to buy and use metal silos. In my self-help group every member has a metal silo.

In a same vein, the Ari Kasi Nguvu Mpya group had promoted the goals of sweeping household surroundings, avoiding littering and using racks (vichanja) for drying kitchen utensils in the sun. They also supported ideas such as the production of safe, clean drinking water by boiling and the use of garbage pits, toilets and hand-washing. These practices received positive response and now households increasingly observe environmental cleanliness and help in the minimization of diseases outbreak such as cholera. Moreover, self-help groups often strengthen social responsibility and social ties in the wider community (Aikaruwa et al. 2014). For the groups interviewed, social responsibilities included providing food, clothing and other requirements for the disadvantaged in the village. The groups regularly helped "those in need", 
thereby playing a role in local social protection systems in the absence of national, public provision (Green 2012a).

Banks et al. $(2015,709)$ suggest that local, grassroots, membership-based organizations in the Global South generally hold "oppositional relation" with the state in terms of pressing for accountability. Our experience in the context of the study did not support this suggestion. Few groups addressed issues outside their immediate communities, and even fewer, if any, engaged in activities aimed at explicitly pressuring the government to provide greater accountability or ensure citizens' rights. While many group initiatives resulted from the fact that the government was not delivering expected services, rather than claiming better delivery or waiting for contributions from external actors, they engaged in self-reliant practices directed at actively solving problems. The account from Upendo describes the general attitude:

Although we were mobilized to open a bank account as one of the requirements for getting loans from the district local government and NGOs, we have not received any loan from anywhere. Now we continue to borrow money from our VICOBA to solve our problems; we cannot stop.

Furthermore, the general opinion was that politics and politicians are unreliable, and most groups demonstrated little interest in getting involved in the political sphere. The common national slogan, "politics should be separated from development issues" (tusichanganye mambo ya siasa na maendeleo) was frequently cited. However, some groups had an explicit political attachment to the ruling party, Chama Cha Mapinduzi (CCM). For example, Ari Kasi Nguvu Mpya had mobilized the community to support CCM contestants during electoral campaigns. After the elections, however, it transformed into a general self-help group dealing with its own socio-economic challenges through vegetable production and keeping about 200 chickens. Later, its old the chickens and bought goats, opened a bank account and, at the time of interview, planned to purchase a maize-milling machine in order to generate income for group members.

All in all, the groups were very active in addressing different problems related to generating livelihoods and dealing with members' short-term cash shortages. They also engaged with village-level problems related to cleanliness, access to water and support for the less privileged. The problems addressed, however, did not directly relate to an observed non-realization of rights or inadequate government accountability; rather, according to their own accounts, the groups had successfully worked to improve the economic status of their members as well as providing reliable social support. Moreover, the reflections indicated increased self-esteem, especially among the group leaders. 


\section{How is interaction within self-help groups organized?}

As Stitzlein $(2014,66)$ proposes, one central element in the development of citizenship habits through participation is how interaction with others takes place in the groups and how group interaction is organized and governed. In this section, we focus on participants' accounts of this. Some groups, especially those established for mutual support, have very informal practice, with a low quotient of explicit structures, rules or regulations; they meet, discuss matters of interest and make decisions merely on an ad hoc basis. Other groups, however, have explicit associational structures and regulations such as a constitution. Most importantly, all the groups interviewed considered gradual formalization a positive trend, and many were proud to position themselves as well-structured organizations. Explicit rules and regulations were considered beneficial for the clear distribution of roles, duties and responsibilities. Moreover, participants narrated that rules help to maintain discipline, minimize conflicts and disputes, and encourage proper record keeping, prudent resource use and management, and valuable activity planning; explicit rules also limit the powers of leaders and group members. For example, as an Upendo representative enthusiastically explained:

We started the group without a constitution, then realized that solidarity in the group was not good and decided to make a constitution. Because of that, the group is now stable, we love each other, cooperation is high, and everything is now in the constitution. The constitution has helped us to be punctual and committed to the group. ... Our group is strong because it has a constitution and well-determined leadership. And because of that we are led by explicit and strict rules.

Self-help groups also had well-structured procedures concerning the contributions expected from members for specific events such as weddings or funerals; these could be in the form of labour, cash, utensils and clothes (khanga, vitenge). For instance, in the Mlimani Park group:

If a woman member of the group is bereaved, it is the responsibility of all members to contribute and show moral and material support to the family from the beginning to the end. Some groups have a special uniform to wear at different events, such as funerals and weddings, in order to show their group status.

The accounts of meetings provided in interviews, and our own observations of them, show great similarity with those in Ulanga (Green 2019) and among the Kuria in Mara Region (Rodima-Taylor 2014); they were promptly scheduled to take place once a week at the same time and they followed certain scripts. The meetings of savings and loan groups in particular closely resemble Green's descriptions of meetings in Ulanga (ibid., 113-115). A metal cashbox 
with three padlocks is placed on a small table behind which the group leadership sits; members sit on the ground or on plastic chairs in a semi-circle facing the table with the cashbox. The meeting starts with the three keyholders opening the cash box. The chairperson calls out the distinguishing number of each member - names are not used - in order to check attendance. When a person's number is called, he or she is supposed to respond by reciting the similarly numbered group rule. The balance books are distributed and the weekly contributions made in a pre-defined order and with minimum interaction. At the end of the meeting, the cash box is locked and the chairperson announces the closing of the meeting. Usually, members leave to attend their household chores without much delay or chitchat with other attendees. Green $(2019,113)$ argues that group meetings can be understood like public events in Tanzania more generally, which are "tightly choreographed events at which participants expect their behavior to be governed by explicit rules set out in groups' constitutions as well as by inexplicit expectations". For instance, when the meeting is in progress, members were not allowed to speak without permission from the chairperson or use their mobile phones. The ringing of an unmuted mobile phone or being late without a prior notice received a fine.

In her work on mutual help groups, Rodima-Taylor $(2014,563)$ observes that written documents and by-laws were very significant even in nonregistered groups that did not necessarily need them. She argues that regulations had symbolic significance, "but offered little resource for solving disputes", situations in which peer pressure and negotiation were mainly used in seeking settlement (Rodima-Taylor 2014, 563). This observation also applies to the self-help groups in Kondoa. Despite having explicit regulations, in their everyday activities groups balanced between following their constitution strictly and a flexible adaptation of rules. Ultimately, the strict application of rules was found unpleasant. Two groups had lost members due to strict adherence to regulations, and interviewees narrated that rules have even scared off potential new members and discouraged them from joining. Nonetheless, sometimes groups took severe action against members who violated them. For instance, as a member of the Mlimani Park group told us:

There was a time when we reached a point of suspending or expelling some members from the group, something which sometimes we would not want to do. But since this is what our constitution says there is nothing we can do.

In other cases, flexibility was exercised and negotiations allowed, especially when it came to delays in loan repayment. A Neema A member told us that when one of the group fails to repay a loan on time, the leadership sits down with whoever it is to discuss the best way to deal with the matter without causing the person harm and to prevent the situation worsening. Rodima- 
Taylor $(2014,562)$ argues that the mutual help groups she explored combined fragmented elements of formalization and traditional and kin-based templates, especially when solving disputes. In our case, even though groups might list the explicit consequences of different malpractices, they also used familial models in settling group disputes. For example, a member who misbehaves or violates any of the rules faces a disciplinary committee of two members. After the hearing, the committee will determine a penalty according to the offence committed. If the member agrees to pay the fine then the matter ends there and the committee reports to the group. As someone from the Upendo group observed:

In our group, sometimes members quarrel. When this happens, concerned members are taken to shangazi and mjomba for dispute settlement.

The interesting point here is that the status of two members of the committee, shangazi (aunt) and mjomba (uncle), is derived from the social respect given to them in many Tanzanian ethnic groups, especially in conflict resolutions. This family model is used as a substitute for the direct application of explicit rules, providing an opportunity to resolve disputes amicably and leave the group united.

\section{Who participates in self-help groups?}

While the internal interaction geared toward shared problems in social groups is central to acquiring citizenship habits, it is also important to address the question of who can participate in or join these groups in the first place (Holma \& Kontinen 2015). Participation can be an individual choice, but some characteristics of group practices may also affect who is eligible for membership. Although self-organized groups are primarily perceived as a means to achieving development, financial inclusion and empowerment, they generally have barriers to participation (Brody et al. 2017, 21). In the Tanzanian context, Mercer (2002) has shown how the wealthier rather than poorer women in a community joined self-help groups. Similarly, Rodima-Taylor (2014, 561) argues that mutual help groups can actually further uneven wealth accumulation in communities. Relevant to this issue, our interviewees were ready with explanations of who was eligible to participate in their selfhelp groups, most of which related to gender, income and the reputation of being a "good person".

As the self-help groups under analysis were concerned with issues of social development, joining one was generally considered "women's business". A frequently articulated view was that since women have a common understanding of issues that concern them, it is easy for them to organize themselves as a group. Moreover, when group activities involved cooking or dancing at various events, these were perceived as purely female pursuits in which men could not possibly participate. Some groups had both male and 
female members, but women comprised the majority in most. Indeed, the characteristics of "bad" and untrustworthy were attached to men as provisional members in general, especially in regard to borrowing and paying back loans. For example, a Mazingira member stated:

Our group is composed only of women because men are not much to be trusted. Also some are aggressive in such a way that when they borrow and fail to repay loans, no one will dare to force him to pay.

However, the few male members often assumed leadership positions, illustrating the complex idea that while men, as a general category, were perceived as insufficiently trustworthy even to be a member, those who were members were highly appreciated. This was partly due to its being taken-for-granted that men would aspire to be leaders in a mixed-gender group, something also prevalent in other spheres, such as religion and the household, wherein men typically were considered more capable and powerful. Indeed, gender dynamics in the household had strong implications for women's ability to participate in self-help groups in the first place. Some members narrated how their husbands had first opposed their participation but, after seeing the financial benefit, had started to support them. In one of the group discussions, one of the women described this process:

I went back home after a self-help group meeting, I told my husband that I got Tsh 100,000 that we could use to solve our problems. After seeing the benefit of joining the group, he was happy and is now supporting me. Even at the point when I don't have money to pay loans and buy shares (kugonga hisa hisa).

The tendency for men to fill leadership positions in the groups also relates to the reasons why they were included in the first place. For instance, men holding formal leadership positions in the village were desirable group members, and readily given leadership positions due to their already existing status in the community. In general - something related to community status members must originate in the locality. As stated by an interviewee from the Jitegemee group, "the first membership criterion is to be from the village" (sifa ya kwanza awe mwanakijiji). Origin was important as membership could only be granted to those with a "good reputation", which was related to one's ability to earn an income and general good behaviour. Reputation was also linked to age, with youth in general being considered unreliable. As one of the Upendo group leaders explained:

We need to observe them [the youth], those who have job here, because you cannot just have a young person of twenty-five years, sometimes he/ she does not have even a place to live, he still depends on his parents. If he takes TZS 500,000, will he really come back to pay? 
Moreover, the explicit and strictly upheld rules governing participation were themselves criteria for membership, which was not available to those unable to contribute. The requirement of weekly cash contributions in all the groups, and the social expectation of taking out a loan at some point in the saving groups, excluded those suffering economic hardship. In order to join, one had to have attained a certain economic level, which varied according to group; in some of those engaged in agriculture, a prerequisite was having land and existing cultivation activity, while in some small groups a minimum weekly contribution of 2,000 TZS (approx.0.7 euros) was expected. Those in economic straits or with challenges such as a disability were not perceived as potential members but, rather, as objects of charity and assistance. As a spokesperson of the Jitegemee group observed of their future plans:

We are thinking to share our idea with the village of having a programme to provide assistance to the most needy people in the village, such as children and orphans living in risk environments, very old ones and people with disabilities who cannot involve themselves in working. This can help in taking good care of them. For now we are helping but not much. If we have a programme in the village, we can help better in terms of providing them food, cleaning and clothes.

\section{Habits of contributing citizenship}

In this section, we reflect on the kinds of citizenship habits acquired through participation in self-help groups, and how these relate to the competencies required to fulfil aspirations for active citizenship engagement (Gaventa \& Barrett 2012). We suggest that one of the prevalent citizenship habits engendered by self-help group practices - a disposition to think and act jointly when organizing and interacting in any situations where shared problems are addressed and common good promoted - is what we call "contributing citizenship". Obviously, contributing citizenship is not the only habit acquired; however, it effectively captures tendencies in members' descriptions of their groups and relationships with other actors. The issues addressed included how groups can contribute to solving the immediate problems encountered by their members, such as shortage of cash for school fees, in adequate harvests or the need to deal with a sudden death in the family. Additionally, groups were constantly conscious of what and how their members should contribute, which included time, money and labour allocated to group activities. In many interviews, descriptions of what made a good member were quite similar:

If I were a member in your group, what should I do in order to be a good member (mwanachama hai)?

Good member? You would pay your contributions (michango) and come to the meetings. That would make you a good member. 
Thus, many explicit rules and regulations were concerned with the requisite member contributions, while groups were inclusive of those having the capability to contribute due to wealth, status or reputation. Groups, in turn, also contributed to general community wellbeing by helping the less privileged and undertaking initiatives related to water and health. The centrality of "contributions" in the interviewees' accounts reflects the general patterns of Tanzanian community life, where "people continuously need to contribute (kuchangia) in money or foodstuffs, to weddings, funerals, and the annual memorial events for dead relatives and neighbours, in addition to the fundraising efforts of churches and village government" (Green 2019, 109).

The notion of contribution also effectively captures the manner in which the groups described their relationships with village governments. Here they mentioned the instances they have been invited to contribute to social events by the village leaders, or how they had contributed to joint village challenges such as a lack of clean water or appropriate toilets, the promotion of healthy nutrition and the selection of the best crops to cultivate in the fields. Thus, the ways in which the groups reflected on their relationship with the government sectors differs from suggestions by Banks et al. (2015) that local memberbased groups generally have a contentious relationship with the government which is geared towards claiming their rights. With little exaggeration, one can say that while "active citizenship" often refers to engaging with local government in order to claim rights and demand accountability, in practice the groups demonstrated their position vis-á-vis local government by providing food, utensils and cultural programs to the Mwenge festivities the latter arranged, and were ready to contribute their ideas, labour and resources to joint village programs.

Gaventa and Barrett $(2012,2402)$ suggest that by participating in groups people become "better citizens" as they develop greater civic and political knowledge, greater awareness of rights and empowered self-identity. Our experience showed that groups tended to maintain an explicit distance from "politics", except for those campaigning for the ruling party. Moreover, groups were very active in pursuit of knowledge and innovation in regard to, for instance, more effective agricultural methods, better food storage and good quality pit latrines. They were eager to learn about village banking models, establishing and governing associations, and how to open bank accounts and use mobile-banking services; in the course of this, their extravillage networks with NGOs, government officials and universities underwent continual expansion, and their practices changed on the basis of new knowledge. Such activities did not directly impact on their political capabilities (King 2015) or increase their awareness of rights (Gaventa \& Barrett 2012), but they certainly empowered members' self-identity. Many of the women with whom we talked were very proud of their ability to lead successful groups and to learn and apply new technologies, or of being members of groups that initiated new ideas for the entire village. Moreover, the opportunity to establish a small business with credit provided by the groups supported 
the self-identity of women as capable and, at times, very successful entrepreneurs at the local level. Groups were also very proud of their reputations in the community. Their active contributions have been acknowledged by village leaders, and gradually, some groups have also been invited to be heard on general issues.

Finally, we suggest that the persistence of contributing citizenship is easy to understand in light of Tanzania's historical and institutional contexts. From a pragmatist perspective, habits provide continuity between past and future to the extent that they are "inherited from our forerunners" (Dewey 1922/2012, 13). Thus, self-help practices were embedded, not only in contemporary forms of organizing, but also in long-term African traditions and social habits of being a citizen in alignment with, rather than contesting the authorities (Dorman 2014) - of contributing to the state rather than claiming from it. Moreover, current citizenship habits also reflect the legacy of Ujamaa - the policy that emphasized the active participation and contribution of every citizen to the development of the country which is still prevalent in political language in Tanzania today (Fouéré 2014, 18).

\section{Conclusions}

In this chapter, we have described the nature and practices of a number of village self-help groups in rural Tanzania, reflecting on citizenship habits acquired through participation in them. Among the most prevalent of these is "contributing citizenship": a disposition to think and act in situations where shared problems are addressed or the common good promoted, which is primarily influenced by people's interest in what they can or should contribute, rather than in their rights or entitlements. In light of these findings, therefore, it can be claimed that the apparent associational activeness of members of rural communities does not directly resonate with the notion of active and engaging citizenship promoted in much of the development literature and practice (see also Nguyahambi \& Chang'a, this volume).

Our exploration has showed that rural people are active citizens when it comes to organizing joint problem-solving, addressing issues regarded as important - the latter mostly related to livelihoods, showing solidarity in challenging times and attending to the common good at the community level. Our observations resonate with King's $(2015,742)$ findings in rural Uganda that, in terms of promoting increased political engagement, organization connected with livelihood issues emerges as a more effective strategy than that aimed solely at promoting citizen participation within local government spaces. It was also apparent that skills and competencies learned in the groups supported new kinds of agency that encouraged people, especially women, to become more vocal and self-confident and to expand their networks in order to access knowledge of use to them. Moreover, local governments had come to recognize and appreciate self-help groups and their members due to their development initiatives; thus, although the groups were 
not directly preoccupied with claiming rights and contesting government policy, they were gradually creating spaces for voices to be heard. In an imaginary situation in which such groups did not exist, the experiences and ideas of their members would not be acknowledged by local governing bodies to the extent they are today.

\section{Notes}

1 The first author contributed mainly to the literature review; the second and third authors made equal contributions to the findings sections as well as carrying the main responsibility for data collection and analysis; the fourth author is the PI of the project and contributed to data collection and the overall design, content and structure of the chapter.

2 The Uhuru Torch (Mwenge wa Uhuru), literally (Torch of Freedom), is a kerosene torch symbolizing freedom and light, which is one of the national symbols of Tanzania. It was first lit on top of Mount Kilimanjaro on December 9, 1961 by Alexander Nyirenda (one of the Tanzanian heroes who had carried it there) with the symbolic goal of shining across the country and its borders to bring hope where there is despair, love where there is enmity and respect where there is hatred. It is still used to highlight evil doings such as corruption while also advocating development projects. The Uhuru Torch race takes place every year starting and ending from different places in the country.

\section{References}

Aikaruwa, D.B., Sumari, G.A. \& Maleko, G.N. (2014). Social functionality of Self Help Groups in Tanzania. Journal of Business Administration and Education, 5(2), 99-136.

Allen, H. (2006). Village savings and loan associations: sustainable and cost effective rural finance. Small Enterprise Development, 17(1), 61-67.

Anand, J.S. (2002). Self-help groups in empowering women: Case study of selected SHGs and NHGs (Discussion Paper Number 38). Kerala Research Programme on Local Development. Centre for Development Studies, Thiruvananthapuram. Retrieved from shodhganga.inflibnet.ac.in/jspui/bitstream/.../13/13_reference.pdf

Banks, N., Hulme, D. \& Edwards, M. (2015). NGOs, states, and donors revisited: Still too close for comfort? World Development, 66, 707-718.

Bouman, F.J.A. (1995). Rotating and accumulating savings and credit associations: A development perspective. World Development, 23(3), 371-384.

Brody, C., de Hoop, T., Vojtkova, M., Warnock, R., Dunbar, M., Murty, P. \& Dworking, S.L. (2016). Can self-help group programs improve women's empowerment? A systematic review. Journal of Development Effectiveness, 9(1), 15-40.

Dewey, J. (2012) Human nature and conduct. Digireads Publishing. (Original work published 1922).

Dill, B. (2010). Community-based organizations (CBOs) and norms of participation in Tanzania: Working against the grain. African Studies Review, 53(2), 23-48.

Dorman, S.R. (2014). Citizenship in Africa. In E.F. Isin \& P. Nyers (Eds.). Routledge handbook of global citizenship studies (pp. 161-172). London: Routledge.

Englund, H. (2004). Introduction: Recognizing identities, imagining alternatives. In H. Englund \& F. Nyamnjoh (Eds.). Rights and the politics of recognition in Africa (pp. 1-32). London: Zed Books. 


\section{Kilonzo, Matunga, Chang'a and Kontinen}

Fouéré, M.-A. (2014). Julius Nyerere, Ujamaa, and political morality in contemporary Tanzania. African Studies Review, 57(1), 1-24.

Gaventa, J. \& Barrett, G. (2012). Mapping the outcomes of citizen engagement. World Development, 40(12), 2399-2410.

Green, M. (2012a). Co-producing ineffective states: Social knowledge, social policy and social citizenship in Africa and in development (ESID Working Paper Series No 14). Retrieved from www.effective.state.org

Green, M. (2012b). Anticipatory development: Mobilizing civil society in Tanzania. Critique of Anthropology, 32(3), 309-333.

Green, M. (2019). Scripting development through formalization: Accounting for the diffusion of village savings and loans associations in Tanzania. Journal of the Royal Anthropological Institute, 25(1), 103-122.

Holma, K. \& Kontinen, T. (2015). The rocky road of growth into contemporary citizenship: Dewey, Gramsci, and the method of democracy. Studier iPadagogiskFilosofi, 4(2), 24-37.

Holma, K. \& Kontinen, T. (2019). Practices and habits of citizenship and learning. In this volume

Hunter, E. (2008). Revisiting Ujamaa: Political legitimacy and the construction of community in post-colonial Tanzania. Journal of Eastern African Studies, 2(3), 471-485.

Ibhawoh, B. \& Dibua, J.I. (2003). Deconstructing Ujamaa: The legacy of Julius Nyerere in the quest for social and economic development in Africa. African Association of Political Science, 8(1), 59-83.

King, S. (2015). Political capabilities for democratization in Uganda: good governance or popular organization building? Third World Quarterly, 36(4), 741-757.

Le Polain, M., Sterck, O. \& Nyssens, M. (2018). Interest rates in savings groups: Thrift or threat? World Development, 101, 162-172.

Lewis, D. (2002). Civil society in African contexts: Reflections on the 'usefulness' of a concept. Development and Change, 33(4), 569-586.

Mercer, C. (2002). The discourse of 'maendeleo' and the politics of women's participation in Mount Kilimanjaro. Development and Change, 33(1), 101-127.

Merrifield, J. (2002). Learning citizenship (Institute of Development Studies Working Paper 158). Retrieved from www.participatorymethods.org

Nguyahambi, A., Kontinen, T., Kilonzo, R. (2017, August). Exploring experienced citizenship in Tanzania. Paper presented in (Un)Making Europe: Capitalism, Solidarities, Subjectivities. Conference of European Sociological Association. Athens, Greece.

Nguyahambi, A.M. \& Chang'a, H.H. (2019). Social accountability monitoring as an approach to promoting active citizenship in Tanzania. In this volume.

Nguyahambi, A.M., Chang'a, H.H., Matunga, B.N., Kilonzo, R.G. \& Kontinen, T. (2019). Contextualizing citizenship in Tanzania. In this volume.

Rodima-Taylor, D. (2013). Gathering up mutual help: Relational freedom of Tanzanian market-women. Social Analysis, 57(3), 76-94.

Rodima-Taylor, D. (2014). Passageways of cooperation: Mutuality in post-socialist Tanzania. Africa, 84(4), 553-575.

Schneider, L. (2004). Freedom and unfreedom in rural development: Julius Nyerere, 'Ujamaa Vijijini', and Villagization. Canadian Journal of African Studies/Revue canadienne des études africaines, 38(2), 344-392.

Sheikheldin, G.H. (2015). Ujamaa: Planning and managing development schemes in Africa, Tanzania as a case study. The Journal of Pan African Studies, 8(1), 78-96. 
Stitzlein, S.M. (2014). Habits of democracy: A Deweyan approach to citizenship education in America today. Education and Culture, 30(2), 61-85.

Thorp, R., Steward, F. \& Heyer, A. (2005). When and how far is group formation a route out of chronic poverty? World Development, 33(6), 907-920.

Tripp, A. (1994). Deindustrialization and the growth of women's economic associations and networks in urban Tanzania. In S. Rowbotham \& S. Mitter (Eds.). Dignity and daily bread (pp. 139-157). London: Routledge. 
$\Longrightarrow$ Taylor \& Francis

Taylor \& Francis Group

http://taylorandfrancis.com 


\section{Part III}

\section{Transformative ideals and incremental change}


$\Longrightarrow$ Taylor \& Francis

Taylor \& Francis Group

http://taylorandfrancis.com 


\title{
11 Participatory methodology in exploring citizenship
}

\author{
A critical learning process
}

\author{
Karembe F. Ahimbisibwe, Alice N. Ndidde and \\ Tiina Kontinen ${ }^{1}$
}

\section{Introduction}

In this chapter, we shift the focus from analysing citizenship practices to reflecting on learning within the research process of exploring everyday citizenship. To this end, we provide a narrative of our experimentation with participatory research methodology when investigating the daily practices and participation patterns of citizens in two districts in rural Uganda. "Experimentation", in this context, refers to an endeavour in which we reflectively tested actualizing the participatory methodology that we considered the most appropriate for this research.

Participatory research methodologies have gained prominence in a range of research disciplines in recent decades. Considered a counterforce to the socalled traditional or extractive methods in the social sciences which are geared towards "data collection" by researchers, participatory methodologies broadly aim to develop the capacity among local people to co-produce and analyse knowledge, as well as determine and address the root causes of their lived problems and issues as they work for social change (Berryman et al. 2013; Williams 2005). In tracing the origins of participatory research methodologies, MacDonald (2012) posits three main strands: the action research developed by Kurt Lewin (1946/1948); the critical pedagogy of Paulo Freire (1972); and the different participatory (social) movements in promoted in development studies and other fields of research (Chambers 1994; Maguire 1987). Each of these strands, in their own way, converge in their strong commitment to working with grassroots groups to promote fundamental social transformations (Healy 2001, 94) by enabling "individuals to identify and analyse their own problems and influence their own situations" (Sohng 1992, 5). Participatory methodologies have also advocated change in the power relationships between planners and workers, adult educators and learners, and development agents and their beneficiaries. Increasingly, many fields of social research, including education and development studies, have adopted participatory research on the grounds that it allows people the space to determine their own development and participate meaningfully in the process of analysing their own solutions in order to lead to the design of relevant 
interventions and sustainable development (Chilisa \& Preece 2005; Attwood 1997; Chambers 1994).

For a long time, we - the first two authors of this chapter - have been passionately committed to participatory methodologies in our research and teaching at Makerere University, considering that their ideals provide a mutual learning and an empowering experience for the research participants. Additionally, we were also convinced that they comprise the best possible way to explore lived experiences of citizenship, as they enable co-construction of knowledge related to local citizenship practices rather than starting with definitions of citizenship provided by the research literature (Isobell et al. 2016; D'Cruz \& Gillingham 2017). As our experimentation began however, we were also conscious of the criticism levelled against, and shortfalls of participatory methodology in general. These include its superficial use in order to legitimate predesigned development interventions (Cooke \& Kothari 2001), its utopian goals concerning the potentiality of research to contribute to societal transformation, and the impossibility of doing away with certain power and knowledge differences between researchers and research participants (Bergold \& Thomas 2012; Pain \& Francis 2003). Such identified discrepancies between the ideals and practices of participatory methodologies motivated us to undertake a critical analysis of our own research process. Therefore, in this chapter, we reflect on two things: a) how we implemented a participatory methodology in this particular research initiative; and b) in which ways tensions related to the actualization of aspirations for mutual learning and empowerment were manifested in the course of it. In what follows, we first describe the process of opting for a participatory methodology in the GROW project discussed in this book (see the Introduction of this volume), and the way it was used in practice in our research on lived experiences of citizenship in rural Uganda. Second, we provide a critical reflection of how and in what ways the discrepancies between ideals and actual practices manifested in this particular case and, finally, we conclude by elaborating on the lessons learned.

\section{Designing the methodology: Opting for narratives and participatory approach}

According to Berryman et al. (2013), participatory research is a process rather than an event, one that begins and ends with "people". It is difficult to identify the exact starting point of this particular research project but, to be frank, it began with brainstorming among researchers rather than interaction with people, with some scattered ideas for GROW existing long before writing the approved proposal in 2014. These were further developed in the joint kick-off seminar in autumn 2015. The detailed design of the fieldwork methodology was scrutinized in a three-day project seminar held in Kampala in June 2016. The participants included the chapter authors together with two Tanzanian colleagues. At this seminar, we made a number of key decisions regarding the 
nature and direction of the intended research. As we were committed to a general pragmatist perspective, we agreed to focus on lived experiences: the ways in which people in communities understand, give meanings to and practice citizenship (Kabeer 2005). At this point, the encounters between these lived experiences and interventions designed by civil society organizations to strengthen citizenship were also of interest.

As a result of our conversations, we agreed that narrative inquiry (Clandinin 2006) combined with a participatory methodology would work best at capturing lived experiences of citizenship. It would also provide an enabling conversational platform for research participants (Quaynor 2015; Minkler 2004) as well as build a strong learning relationship between researchers and participants (Berryman et al. 2013). Using the languages spoken and understood by the local communities, we designed a way to inquire into people's citizenship experiences, and to learn about the groups and communities of belonging of those taking part. For the latter aim, we opted to use one of the main tools in participatory methodologies - a Venn or Chapatti ${ }^{2}$ diagram in order to enable participants to identify the groups of significance for them, and further, analyse the extent of significance of these different groups in their everyday practices. Guided by participatory research principles, we aimed to enable participants to become co-researchers, co-learners and co-instructors of knowledge, meanwhile building a successful and trustworthy research rapport (Genat 2009; Isobell et al. 2016; D’Cruz \& Gillingham 2017). The narrative approach guided us to inquire about stories of participation, and to prompt participants to offer practical examples of different events rather than merely listening to them listing the groups and their significance. The main tension confronting us at this stage was how to distance ourselves from our own, scholarship-informed notions of citizenship, and develop a methodology that would allow people to speak from their own perspectives. Practically, for instance, this meant struggling with the translation of "citizenship" into the local languages to be used in interviews so that it would not provide a fixed, ready-made interpretation but would allow room to investigate people's own meanings (see Ndidde et al., this volume).

\section{Whose voice will be heard? Identification of the case NGO, study areas and research participants}

The GROW project was interested in encounters involving NGOs promoting some kind of active citizenship with local communities. Our intention was not to evaluate the performance of these interventions as such but, rather, to reflect with the community members on how their interaction with the NGO had facilitated their potential growth into citizenship (Holma \& Kontinen, this volume), and whether this was cascading into lived experiences of citizenship identity, belonging and practices. Thus, we set out to identify a case NGO based on the criteria of it having been involved in mobilizing and sensitizing citizens for development work and citizen advocacy, as well as having 
a rich history and experience of working with marginalized sections of society. On this basis, three national gender-advocacy NGOs were initially selected and formally invited to be part of the project, and finally, after several meetings and negotiations with the NGOs in July 2016, we decided to work with Action for Development (ACFODE) (see Kontinen \& Ndidde, this volume).

ACFODE suited our aims of investigating NGOs involved in strengthening citizenship. Established in 1985, it has been at the forefront of championing a women's empowerment crusade through consolidated advocacy of gendered policy formulation, research, capacity building, coalition building, mobilization and sensitization. Moreover, ACFODE has conducted extensive citizenship activities and interventions in all five regions of Uganda, focusing on building the capacities of communities and leaders to promote good governance and to improve their socio-economic transformation. The NGO also has a participatory attitude and has built good relationships with communities, which presumably decreased the suspicion of community members towards us as researchers. Moreover, the national coverage of its activities provided the research team with a variety of choices of districts in which to work. Based on this understanding, it was decided that the research would be conducted in two districts: Kiboga $^{3}$ in central Uganda and Namutumba ${ }^{4}$ in eastern Uganda. The choice was influenced by the fact that the researchers had an understanding of the languages spoken in the two areas and would not need interpreters. The ability of researchers to interact directly with community members is important for the successful implementation of participatory research.

When it comes to the selection of research participants in the communities, a central concern in participatory methodologies is who will be included and excluded. Critical observations have claimed that those who attend participatory exercises are usually the most well-off and privileged members of a community (Janes 2016). In our case, the participants were selected from among those who had had encounters with ACFODE activities in their citizenship strengthening programs. With the assistance of the NGO's focal persons in the communities, 60 participants were identified for individual indepth interaction in their homes and/or workplaces. The participants in Kiboga district were mainly local leaders who had received training in leadership and governance while, in Namutumba, participants were community members who had received training in livelihood and socio-economic transformation interventions. While participatory research often uses group-based methodologies, we opted for individual interviews for two main reasons: strategically, we did not want to involve participants in bothersome travel from their areas of residence to the location of participatory exercises, as this would have also brought in the logistical issues of transport refund and time delays; practically, we wanted to initiate a process of mutual learning with participants in their own everyday environments. Our choice of individual interviews therefore provided ample time and space to focus on individual 
participant reflections and experiences, albeit this could have denied us the benefits that could have accrued from having joint discussion, engagement and analysis among group participants.

Getting consent from research participants is an important element of any research initiative, as it ensures that they willingly and voluntarily accept being part of it (Araali 2011). In this respect, we encountered a tension between "standardized" and "local practice" ways of obtaining consent. The team had a detailed, seven-page consent form translated from English into the local language, Luganda, as required by the Ugandan National Council for Science and Technology. According to these official requirements, the participants were expected to read, understand and sign the consent form as a confirmation of their willingness to participate in the exercise. If participants had any queries, the consent form advised them to contact the Finnish Principal Investigator (PI), either by phone or email. Such a consent form, standardized practice in "Western" research culture, smacked of the oftencritiqued power relations embedded in North-South research collaborations (Bhattacharya 2007), despite it being a Ugandan institution that required its administering. Further, the consent form requirements also ran counter to both African social practices and the spirit of participatory research. In the African communal way of living, a visitor is treated as a visitor (Jegede 2009), so that once one has been accepted into somebody's home, one is treated with the utmost sincerity and courtesy (Araali 2011). In addition to appropriate informal greetings and conversations, part of our rapport-building involved giving a detailed oral explanation of the purpose of the study and summarizing the contents of the voluminous consent letter to gain the actual consent of the participants. In the end, they willingly signed the consent form and agreed to having conversations audio recorded.

\section{Coming down from the Ivory Tower: Positioning and revealing ourselves}

In participatory research, reflecting on the positionality of the researcher is critical for mutual engagement and learning (Berryman et al. 2013; MacDonald 2012; Jackson 1994). It requires researchers to make their biases transparent (Berryman et al. 2013) and to be conscious of who they are and how their positions impact on the people with whom they are working. Initially, the two researchers - the first and second authors of this chapter - entered the communities and introduced themselves as coming from Makerere University, a premier university in Uganda and beyond. Locally, the name Makerere University is synonymous with power, knowledge and prestige. In common local parlance, Makerere University is popularly known as Akasozi k'abayivvu (the Hill of the Elites, the "Ivory Tower"). Being part of an elite class was an inevitable identity we carried into our interactions with the community participants. However, while we introduced ourselves as researchers from Makerere University, we hastened to emphasize that we were in the area as "outsiders" who knew little or nothing about local lived 
experiences. We emphasized that we were in the community not as experts but as people who had come to learn. Before commencing the actual interview, we often engaged in informal chit chat with the participants in a conscious attempt to establish cordial relationships despite the expected power relations. We often politely declined to sit on the prearranged "special" seats usually reserved for "important" guests and insisted on sitting where we found the participant seated. We also conducted the interviews in the local dialects, Luganda and Lusoga respectively. A typical introduction to the research interaction was as follows:

Thank you very much mama. Let me introduce myself: I am called AK, from Makerere University. We are in your village of Bubago to converse with people like you about their views as citizens of this area. . . Like I explained before, we're here to talk about obutyamye (citizenship) and abatyamye (citizens) and we'll be pleased to hear your experience as a citizen, as well as your independent opinion on various issues we would like to discuss together. . . . One thing I'd like to emphasize is that we are not looking for specific or pre-conceived and/or right/wrong answers/responses from you but your unique experience as a citizen of this area.

(An introduction to the research participant, Namutumba district, May

These introductions and other pre-interview activities in the homesteads helped set the tone of the participatory interaction and the attendant Venn diagramming exercise. To some extent, it helped create an atmosphere of mutuality, respect and reassurance for the participants. In terms of the outsider/insider debate, the researchers had different levels of outsiderness. The first author is not a native speaker of either Luganda or Lusoga, albeit having a relatively strong functional knowledge of both languages. The second author is a native Muganda and fluent speaker but also with functional knowledge of Lusoga. In some cases, in Namutumba, we encountered participants who could not speak Luganda and therefore, a mixture of the two languages was used. In such circumstances, the self-introductions set the pace for the engagements and improved as the interaction proceeded. Revealing our self-identity and the declaration of minimal knowledge on our part evidently created a situation of trust and emphasized participants' role as those who are knowledgeable. A typical prelude to the interview would go thus:

My name is AK, I'm here to have a conversation with you about your experience as a citizen (omutuuzelomutyamye) of this area. I am not a native Muganda/Musoga but I have some reasonable functional knowledge of the language. I can speak it and even listen to it. Where I can't express myself properly, I will ask you to guide me. . . 
It can thus be argued that, from cultural-linguistic perspective, the first author was an "outsider" in both areas, while the second author was an "insider" in Kiboga and an "outsider" in Namutumba; however, from a social status and education perspective, both were "outsiders". Although we remained relative outsiders owing to our position as educated researchers who were not residents of the area but from a university and carrying files of papers and voice recorders, our consciousness and admission of these limitations played a key role in reducing power gradients during the interaction process. In addition, our expression of ignorance about contextualized experiences in the community disencumbered us of the burden of being seen as experts with authoritative knowledge. Indeed, as the interaction proceeded the participants easily "took over" from us as they reflected on the institutions in which citizenship is exercised and practiced.

\section{Venn diagramming exercise: Imagining and reflecting on "citizenships"}

The leading role of the participants became especially apparent in the course of the participatory method of Venn diagramming that actualized our narrative approach. Venn diagramming is an exercise often used to depict key institutions, organizations and individuals and their relationship with (or importance to) the local community (Sontheimer et al. 1999). In participatory research, this method is used to generate information on who and what persons or organizations are important in and for a community (Adebo 2000, 16). For us, the method facilitated interaction, generating narratives in the course of producing a diagrammatic representation of spaces of participation significant to the research participants. We explained the purpose of using the Venn diagram as a tool to illustrate the series of institutions or groups to which we belong and through which we perform our respective roles and exercise our rights in concert with others in our daily citizenship practices. We further explained that these institutions play different roles in shaping and influencing our own practices in our daily human interactions. We then asked the participants to name such institutions or groups in their everyday life and, as the interaction progressed, they were guided to draw them on the Venn according to their perceived degree of importance in participants' daily citizenship practices. Our final aim was not merely to draw the Venns, but to use them in stimulating self-reflection and learning about citizenship practices in the communities. Typically, the explanations for the Venn drawing exercise went thus:

From what we have shared so far, it looks like you practice your citizenship through a network of institutions and groups. Now I request that we do an exercise to help us understand better the groups or organizations/ institutions that you belong to and their importance to you as citizen of this area. We call this the chapatti exercise. We shall put your chapatti in the middle; for every group you think is most important and useful you 
will draw a chapatti and put it closer to you in the middle. Those organizations that are not very useful will be put at a relatively greater distance from you.

(Interaction with a female participant, in Bubago Namutumba, May

The activity of explaining and drawing diagrammatic representations of the most and less significant institutions engaged participants in processes of thought, learning and reflection as they justified and explained the positions given to the various organizations and groups. This involved back-and-forth drawing and erasure until the participant was satisfied with the position allocated to a particular institution on the Venn. From the point of beginning to draw to the point of a finished Venn diagram, a wealth of interesting insights emerged.

Kibiga Women Solidarity Group should be closer than any other. . we meet regularly. . . we have got friends, we know each other in the area now, we have that togetherness as women of Kibiga. We help each other in times of grief and happiness. When one has got a problem, you see all of them come to comfort you, and they help you in all ways and free of charge. Saucepans, plates, food and every necessary thing is brought, and you feel comforted in a way as they do everything. And we also started a savings scheme; we worked out something and we started saving. We no longer go to the banks to stake our property as security. We save every week and there is an amount of money that we decided we should all save every week, the money that one is able to manage, for instance, two thousand every week. Now if someone needs money, it's collected and given to her, and she then brings it back with a little interest.

(Female Participant, Kiboga, February 2017)

We were cautious with participants, ensuring that they got sufficient time to think about their views before finally putting them on paper. In some situations, we found participants in areas where it was not possible to draw visible Venns due to rough surfaces, very soft sandy surfaces, wet conditions or green compounds. In such circumstances, the level of participation and the flexibility in making changes on the Venns were slightly limited. We mitigated this by using manila paper and markers that we carried with us to draw the Venns with the participants. Further, in practical terms it was not easy to be consistent with either distance and/or size of the chapatti to represent the importance or non-importance of a particular institution or group to an individual. In the end the two would be mixed up as the exercise progressed. For example, the researchers used different explanations during the Venn diagramming exercise, with one emphasizing distance (Figure 11.1) and the other, size (Figure 11.2). 


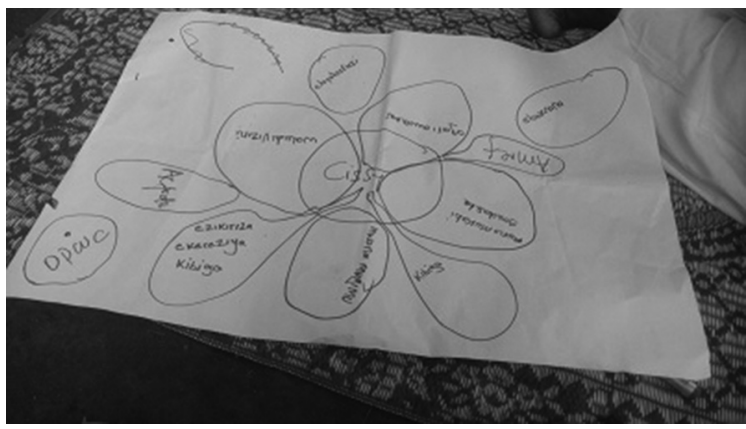

Figure 11.1 A Venn diagram drawn using distance to show groups of non/importance in Namunyuka Village, Kiboga District.

Source: Field photo

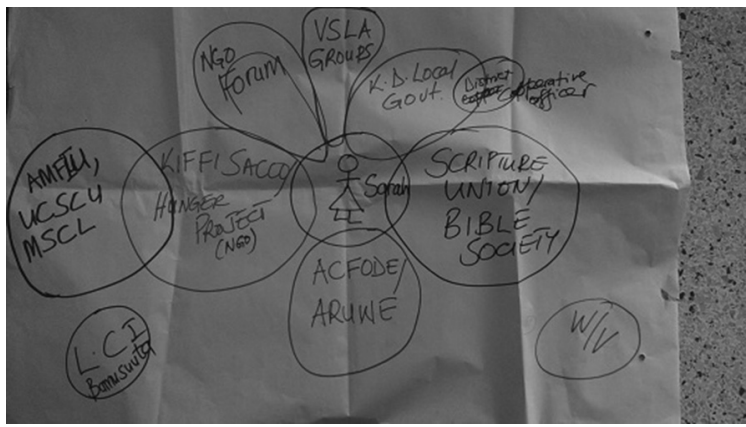

Figure 11.2 A Venn diagram drawn using size (and distance) to show groups of non/ importance in Kajjere Village, Kiboga District.

Source: Field photo

\section{Reflections on power relations, (co-)learning, empowerment and tensions experienced}

Up to this point, our narrative has focused on describing the experiences of experimenting with a participatory methodology in research exploring everyday experiences of citizenship in rural Uganda. In what follows, we reflect on some of the key assumptions of participatory methodologies with regard to issues of co-learning, power and empowerment, and how these assumptions were actualized in our research, which, as in any practice, included tensions with issues that would not totally fit the ideal process of the participatory model. 


\section{Co-learning about citizenship through participatory methodology}

The participatory research literature emphasizes the need to include research participants in processes of inquiry and knowledge production (Bergold \& Thomas 2012). Participatory research methodologies, therefore, aim to empower marginalized communities by believing in their abilities to create and share knowledge through negotiated reflection on their reality (Cauto 1987; Jackson 1994). It is often suggested that participatory research promotes mutual learning and supports reciprocity, friendships and (self-)reflection among the researchers and participants (Genat 2009; Glassman \& Erdem 2014). In our case, with the design of the methodology and its implementation from the time the team set foot in the homes of the participants to the conclusion of the interaction, we aimed to learn about how participants perceived their reality. Based on our reflections, we are confident that our participatory interviews presented critical learning opportunities based on mutuality, reciprocity, friendship and self-reflection among us and the research participants, while the diagramming exercise produced novel knowledge about different belongings and forms of participation as experienced by the participants (Kabeer 2005). Through joint analysis with the participants, we learned about the significance of community-based solidarity groups in which community members supported each other economically and socially. Moreover, the significance of religion became apparent when participants reflected on their own analysis:

From what we have drawn, I think everything should be put inside the circle/chapatti of the church. Without God, all these other activities and opportunities can easily collapse. Therefore, when I go to the church, I go there to pray, and I have other church activities which I do with others...

(Female Participant, Kiboga, February 2017)

Additionally, the back-and-forth reflection on local citizenship facilitated by the Venn revealed the lesser importance that seemed to be attached to "political" citizenship. The analysis showed that the importance of ACFODE's programs for strengthening citizenship was linked to their ability to address people's survival needs. In Namutumba district, where ACFODE was implementing a socioeconomic livelihood program, some voices praised it as ómuzadde waffe (our parent). During the interactive Venn drawing process, participants reflected on how ACFODE, through its training programs, had helped them to improve farming systems, such as planting in rows and improved post-harvest practices, as well as training them in adding value to their crops by, for example, making juice out of avocado, mangoes and oranges. In the course of the interviews, we also understood how such basic livelihood improvements had meanwhile strengthened the women's self-esteem and agency.

During the Venn drawing process, strong voices and statements pointed to the preponderance of different groups, organizations and institutions 
concerned with citizenship practices in the community. We contend that if we had used the traditional tools of data collection, such as a questionnaire or a simple interview schedule based on a theoretically-informed definition of citizenship, we would possibly not have been able to learn about the priorities and meanings participants assign to different citizenship practices. For instance, we might have ignored the utmost importance attached to religion (Figure 11.3), solidarity groups or a profession like teaching (Figure 11.4), in comparison to the NGO programs. While the participatory method provided a tool for the researchers to learn about the experienced citizenship, the participants themselves also appreciatively talked of how the Venn diagramming exercise had "opened their eyes" to look more critically at the role played by different institutions and groups in their daily lives.



Figure 11.3 A Venn diagram of a female teacher and councillor in Kiboga District. She encircles everything with her teaching profession, arguing that her job at a local primary school was the main reason for her involvement in all Source: Field photo the other activities and groups.

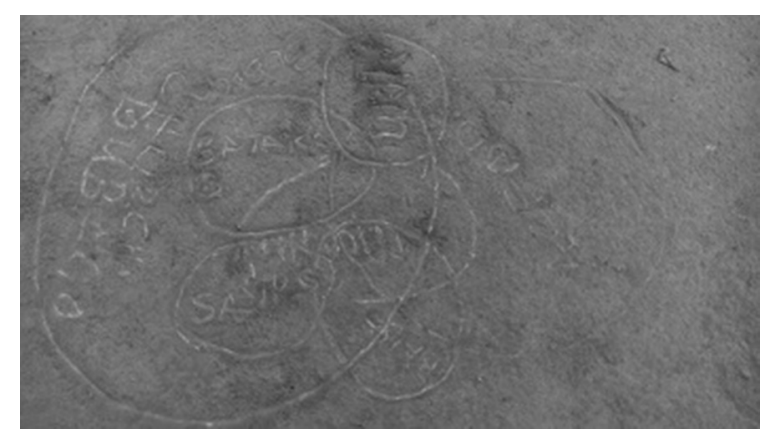

Figure 11.4 A Venn diagram of a male participant emphasizing the significance of religion. He drew a bigger Venn for his local church, Bubago Church of Uganda. "It's Source: Field photo because of God that am still alive and talking to you now", he said. 


\section{Power relations and (the utopia of) empowerment}

Participatory research claims to be a way of flattening power relations between researcher and participants and of empowering marginalized groups (Kabeer 2002; Minkler 2004; Berryman et al. 2013; Isobell et al. 2016). Committed to fostering egalitarian practices, participatory research is assumed to "allow community initiatives to guide the research thereby building capacity and the stimulating critical consciousness among mobilized participants to take action to bring about social transformation" (Isobell et al. 2016). In our case, we entered the communities as researchers from a prestigious university carrying research materials, holding smartphones and driving cars. In most rural areas, these are symbols of power, wealth, elegance, sophistication and elitism. Further, we explained the agenda of the research, gave most of the instructions for drawing the institutions and organizations on the Venn, and generally "dominated" the entire research process. Inevitably, as researchers, we had a kind of privileged status, even though we were guided by the philosophy and spirit of participatory research. However, we were aware that, as Reason $(1994,334)$ acknowledges, "participatory research cannot occur without the initiative of someone with time, skill and commitment, someone who will almost inevitably be a member of a privileged and educated group". What was important to us was that we conducted ourselves with the community in a manner that did not seek to portray us as "powerful" people. For instance, we deliberately refused to sit on raised seats with participants on lower seats, we expressed our inadequate knowledge of the daily experiences of the participants, and we spoke the local languages of the participants. In turn, participants welcomed us and willingly shared their opinions. These actions entreated us to "act out mutual and interdependent power relations" (Hilsen 2006) and significantly created spaces for democratic distribution of power and evenness among the academe and the community knowers (Janes 2016). Our research practice contained the deliberate effort "to flatten the power relations between researchers and participants" (Berryman et al. 2013, 17) as it was our goal to make it an open process of sharing, although it was impossible for us to do away with our position as those structuring, guiding and inviting participants in the first place.

We cannot say much about the more general aim of participatory research to promote empowerment and transformative change (Williams 2005). The process of joint identification of problems and finding solutions for them through changes in local practices and power relationships would have gone far beyond the time and other resources allocated for this particular research project. Thus, based on our experimentation, we cannot claim that our work resulted in the long-term empowerment of research participants. However, based on their immediate feedback, we maintain that participatory interviews were empowering rather than extractive experiences. Participants freely engaged in explaining and interrogating their own notions of citizenship practices as we worked collaboratively throughout the research process to 
such an extent that, by the end of the interactions, participants often jokingly told us that our status had changed from that of bagwiira (outsiders/aliens) to batuuze (citizens) in the community.

\section{Tensions in disrupting the conventional research process}

One of the arguments in favour of a participatory methodology is that it counteracts the practices of more conventional research in the social sciences by emphasizing democratic engagement and the equality of all research participants (Healy 2001; Janes 2016; D'Cruz \& Gillingham 2017). Despite our avowed philosophy, embedded as it is in participatory research, our initial physical appearance and contact with the community members were those of conventional researchers in every sense of the word. In rural areas, the common habit of conducting research follows a template of the "powerful" researcher/"powerless" researched relationship, whereby the former enter the community armed with questionnaires to "collect data" from the respondents. However, as our interaction in the communities continued, our approach potentially presented a disruption in people's usual habits of "being respondents" and trying to provide the "right answers". Instead, we introduced a new habit of doing research, by interacting with participants. This was practically exemplified by our declining to sit on the prearranged seats, and by declaring our cultural and linguistic limitations, which placed us in "a more advantageous position to learn and be guided by the participants in the community as the research turned into a process with people rather than to the people" (Berryman et al. 2013, 265). Indeed, as the interaction proceeded in the communities, members "took charge" of the process as they reflected on the institutions in which their citizenship is exercised and practiced.

On the other hand, our attempts to "do it differently" encountered some practical difficulties. For example, as the process of drawing Venn diagrams commenced, both non-literates and literates who had not held a pen for a long time ${ }^{5}$ had to adjust their everyday habits in order to cope with the task. Whilst some were not open to admit their inability to write and therefore often asked the researchers to do the drawing as they narrated their stories, others were visibly enthused to hold the chalk or markers to draw their Venns. Yet others, owing to their socio-economic status, found drawing on the ground a bit of a kindergarten exercise reminiscent of their infant life when they were beginning to learn to write (Figure 11.5). For example, when we introduced the Venn drawing exercise, a woman leader in Kiboga district said, "You expect me to bend down and start writing and drawing things in the sand like my grandchildren?!" Therefore, while we could see that the participatory method was an empowering and praised exercise for some, for others we had to be flexible about opting for alternative ways in order to ensure their being comfortable and not "forced" to participate in the way that we wanted. 




Figure 11.5 A participant guiding the researcher in drawing her Venn diagram in Kiboga district. She argued that she could not write on the ground as if she was a child.

Source: Field photo

\section{Conclusions}

In this chapter, we set out to describe a process of experimenting with a participatory methodology to explore lived experiences of citizenship in rural Uganda, and to provide a critical reflection on the discrepancies between the ideals and actual practices of the methodology that was demonstrated in this particular case. Based on our experimentation, we can conclude that, in many ways, the participatory methodology we used, supported the aims of learning about the lived experiences of citizenship with people themselves, and contributed to the realization of the ideals of participatory research. First, we were able to create situations where researchers and participants consciously embarked on a tumultuous journey of flattening power relations. Second, the methodological principles made us acknowledge and appreciate the situated uniqueness of community perspectives and experiences on citizenship. Third, the research interactions conducted were able to promote co-learning and co-inquiry through appreciation of the positionality of researchers and participants. Fourth, the participatory interview enabled participants to reflect on and change their perspectives on their citizenship identity and belonging.

However, our experimentation also showed that, given the usual restrictions on time and other resources, deploying a participatory methodology in the course of a single research initiative often remains an isolated, short-term experience of empowerment and mutual learning for both the researchers and the research participants. While we were able to disrupt traditional research practices and undertake alternative models of research characterized by a 
flattened power relationship and co-construction of knowledge, we did not, to our knowledge, contribute to any significant, long-lasting transformation of the research communities. Therefore, we suggest that rather than trying to fulfil all the ideals attached to participatory methodologies of their inherent ability to empower and transform research participants (Berryman et al. 2013; MacDonald 2012; Williams 2005; Schugurensky 2004), research should - while continuously struggling to attain the participatory ideals - also be content with small, incremental changes in research practices.

\section{Notes}

1 The first author has had overall responsibility of the chapter. The first and the second authors conducted the fieldwork analysed in this chapter, initiated the overall idea of the chapter and contributed substantially to each section. The third author is PI of the project, and has contributed to the overall methodological design of the fieldwork, and to the theoretical content and overall structure of this particular chapter.

2 Chapatti is a popular quick food snack made out of wheat flour and cooking oil. It is circular in shape and is often made instantly on many roadside stalls in urban areas in Uganda. Its circular form was used to compare it with the Venn diagram in order help the participants to understand the exercise.

3 Kiboga district is in the central region of Uganda. It is a multi-ethnic district and was the epicentre of the 1980-1985 guerrilla war that left most parts of central Uganda in total ruins. ACFODE has been operating in Kiboga district since 1986, and has implemented a number of interventions in the district purposely to improve women's participation in governance and decision making at local and national levels. It focused on training and equipping women councillors with skills and knowledge on gender, democracy and good governance to understand their roles and responsibilities in society better, assisting them in exercising their rights in the health and education sectors.

4 Namutumba district, located in eastern Uganda, Busoga sub-region, is considered a backwater district with some of the poorest development indicators. Its population growth rate is estimated at 2.7 per cent with an approximate population of 252,562 people (Uganda Bureau of Statistics 2016). From 2012 to 2014 ACFODE worked in the district, addressing famine and malnutrition by strengthening the capacity of households with knowledge and skills on food security, production, storage, value addition and marketing.

5 In rural areas, it is common for people to spend most of their time without writing, especially if they are ordinary citizens without responsibilities that require them to write or read often.

\section{References}

Adebo, S. (2000). Training manual on participatory rural appraisal. Addis Ababa: FSN. Retrieved from www.fsnnetwork.org/sites/default/files/pra_guide.pdf

Araali, B.B. (2011). Perceptions of research assistants on how their research participants view informed consent and its documentation in Africa. Research Ethics, 7(2), 39-50.

Attwood, H. (1997). An overview of issues around the use of participatory approaches by post-graduate students. In IDS, Participatory Research, IDS PRATopic Pack (February, 1997). Brighton: IDS, University of Sussex. 
Bergold J. \& Thomas S. (2012). Participatory research methods: A methodological approach in motion. Historical Social Research, 37(4), 191-222.

Berryman, M., SooHoo, S. \& Nevin, A. (2013). Culturally responsive methodologies from the margins. In M. Berryman, S. SooHoo \& A. Nevin (Eds.). Culturally responsive methodologies (pp. 1-31). Bingley: Emerald Group Publishing Ltd.

Bhattacharya, K. (2007). Consenting to the consent form: What are the fixed and fluid understandings between the researcher and the researched? Qualitative Inquiry, 13(8), 1095-1115.

Cauto, R.A. (1987). Participatory research: Methodology and critique. Clinical Sociology Review, 5(1), 83-90.

Chambers, R. (1994). The origins and practice of participatory rural appraisal. World Development, 22, 953-969.

Chilisa, B. \& Preece, J. (2005). Research methods for adult educators in Africa. Cape Town: UNESCO Institute of Education.

Clandinin, D.J. (2006). Narrative inquiry: A methodology for studying lived experience. Research Studies in Music Education, 27(1), 44-54.

Cooke, B. \& Kothari, U. (Eds.). (2001). Participation: The new tyranny?London: Zed Books.

D’Cruz, H. \& Gillingham, P. (2017). Participatory research ideals and practice experience: Reflections and analysis. Journal of Social Work, 17(4), 434 452.

Freire, P. (1972). Pedagogy of the oppressed. Harmondsworth: Penguin

Genat, B. (2009). Building emergent situated knowledges in participatory action research. Action Research, 7(1), 101-115.

Glassman, M. \& Erdem, G. (2014). Participatory action research and its meanings: Vivencia, praxis, conscientization. Adult Education Quarterly, 64(3), 206-221.

Healy, K. (2001). Participatory action research and social work: A critical appraisal. International Social Work, 44(1), 93-105.

Hilsen, I.A. (2006). And they shall be known by their deeds: Ethics and politics in action research. Action Research, 4(1), 23-36.

Holma, K. \& Kontinen, T. (2019). Practices and habits of citizenship and learning. In this volume.

Isobell, D., Lazarus, S., Suffla, S. \& Seedat, M. (2016). Research translation through participatory research: The case of two community-based projects in low-income African settings. Action Research, 14(4), 393-411.

Jackson, C.A. (1994). Participatory research: A feminist critique. Psychology in Society (PINS), 18, 3-20.

Janes, J.E. (2016). Democratic encounters? Epistemic privilege, power, and community based participatory action research. Action Research, 14(1), 72-87.

Jegede, S. (2009). African ethics, health care research and community and individual participation. Journal of Asian and African Studies, 44(2), 239-253.

Kabeer N. (2002). Citizenship and the boundaries of the acknowledged community: Identity, affiliation and exclusion (IDS Working paper 171). Brighton: Institute of Development Studies.

Kabeer, N. (2005). The search for inclusive citizenship: Meanings and expressions in an inter-connected world. In N. Kabeer (Ed.). Inclusive Citizenship: Meanings and expressions (pp. 1-27). London \& New York: Zed Books.

Kontinen, T. \& Ndidde, A.N. (2019). Learning in a Ugandan gender advocacy NGO: Organizational growth and institutional wrestling. In this volume. 
Lewin, K. (1948). Action research and minority problems. In G.W. Lewin (Ed.). Resolving social conflicts. New York: Harper \& Row. (Original work published 1946).

MacDonald, C. (2012). Understanding participatory action research: A qualitative research methodology option. Canadian Journal of Action Research, 13(2), 34-50.

Maguire, P. (1987). Doing participatory action research: A feminist approach. Amherst: University of Massachusetts Press.

Minkler, M. (2004). Ethical challenges for the "outside" researcher in communitybased participatory research. Health Education \& Behavior, 31(6), 684-697.

Ndidde, A.N., Ahimbisibwe, K.F. \& Kontinen, T. (2019). Gendered citizenship in rural Uganda: Localized, exclusive and active. In this volume.

Pain, R. \& Francis, P. (2003). Reflections on participatory research. Area, 35(1), $46-54$.

Quaynor, L.J. (2015). Researching citizenship education in Africa: Considerations from Ghana and Liberia. Research in Comparative \& International Education, 10(1), $120-134$.

Reason, P. (1994). Three approaches to participative inquiry. In N. Denzin \& Y. Lincoln (Eds.). Handbook of qualitative research (pp. 324-339). Thousand Oaks, CA: SAGE.

Schugurensky, D. (2004). The tango of citizenship learning and participatory democracy. Retrieved from www.researchgate.net/publication/252391396

Sohng, S.L. (1992). Consumers as research partners. Journal of Progressive Human Services, 3(2), 1-14.

Sontheimer, S., Callens, K. \& Seiffert, B. (1999). FAO. PRA Tool Box. Retrieved from www.fao.org/3/x5996e/x5996e06.htm

Uganda Bureau of Statistics (2016). The National Population and Housing Census 2014 - Main Report. Kampala: Uganda Bureau of Statistics.

Williams, L. (2005). Researching, organizing, educating, and acting: Social change and participatory research. Humanity and Society, 29(3-4), 239-259. 


\title{
12 Learning in a Ugandan gender advocacy NGO
}

\section{Organizational growth and institutional wrestling}

\author{
Tiina Kontinen and Alice N. Ndidde ${ }^{1}$
}

\section{Introduction}

A typical goal in the strategies of non-governmental organizations (NGOs) all over the world is to become a learning organization. However, what this actually means and, further, how organizational learning takes place are complex questions. In the field of development NGOs, the notion of a learning organization typically refers to one whose management mechanisms, such as its monitoring and evaluation systems, are geared towards learning, in addition to accountability (Ebrahim 2005; Hayman et al. 2016). Moreover, among NGOs this has been depicted as an ongoing spiral of experiential learning (Fowler 1997; 2000), engagement with local knowledges in beneficiary communities (Chambers 1997; 2017), or the ability to reflect on prevailing power asymmetries in North-South partnerships (Eyben 2006; Fowler 1998). Drawing on Easterby-Smith and Lyles's (2011) distinction, we differentiate between the notions of learning organization and organizational learning. The former refers to mere normative depictions of what a learning organization ought to be (e.g. Senge 1990), while the latter is a phenomenon widely researched from multiple theoretical perspectives and debated in different disciplines including management, social psychology, organization studies and sociology.

In this chapter, inspired by John Dewey's notion of growth (1922/2012; see also Holma \& Kontinen, this volume), we investigate organizational learning which takes the form of a reformulation of habits in response to disruptions and problematic situations (Brandi \& Elkjaer 2016, 147; Lorino 2018). In this instance we examine learning that occurs in what Deweyan pragmatism characterizes as a "community of inquiry" wherein participants jointly negotiate and experiment with new ways of doing things. Thus, we are interested in learning which is embedded in organizations' daily practices as a result of joint reflection and experimentation caused by experienced disruptions.

The communities of inquiry in NGOs do not, however, exist in isolation from their institutional and societal contexts. Indeed, we suggest that learning in individual organizations is both enabled and constrained by the 
institutional environment (Kontinen 2018). Organizational habits acquired and disruptions encountered in development NGOs are often related to tendencies in international development in general and also to the degree of contestation over the role of civil society organizations in a particular state. In order to address these phenomena, we draw on the notion of "wrestlings" (Brandi \& Elkjaer 2016, 153-155), using the term "institutional wrestling" in reference to the enduring tensions that are part and parcel of the processes of organizational growth. This can include, for instance, balancing between managerialism and human-centred management approaches (Claeyé 2014); between perceiving projects as the implementation of blueprints or as adaptive processes of experimentation (Rondinelli 1993); between contributing to incremental change in people's lives or more profound societal transformation (Mitlin et al. 2007; Choudry \& Kapoor 2013); and between being a professional development $\mathrm{NGO}$ or a member-based organization embedded in people's daily needs (Banks et al. 2015).

Action for Development (ACFODE), a Ugandan, gender-advocacy NGO, has provided a fruitful entry point to exploration of the dynamics of learning and wrestling, and is the case study discussed in this chapter. Over three decades of operation, it has changed from a participant in the transformative Ugandan women's movement (Tripp \& Kwesiga 2002) into a more reformist professional organization, altering its strategies and organizational forms in response to encountering the above-mentioned general tensions. ACFODE describes itself as follows:

"We measure, monitor, analyse and improve productivity, process, tasks and ourselves to satisfy stakeholders. We work with enthusiasm and intellect, and are driven to surpass what has already been achieved"

(ACFODE 2016, 4).

Today, the NGO has well-functioning monitoring and reporting mechanisms, produces considerable knowledge to back both its advocacy and community development activities, and engages in critical debates with its donors.

In this chapter we examine the kinds of instances in which organizational growth has taken place in ACFODE and the institutional wrestling that has ensued. In what follows, we briefly depict our organizational learning perspective before introducing the NGO case study and the research methods used. We then reflect on the complexities in ACFODE's core concern of addressing the habits of others, and discuss learning in terms of project implementation, advocacy approaches and organizational restructuring. We show that learning as the reformulation of organizational habits includes continuous balancing and negotiation between, for instance: transformative and reformist agendas; strategies of traditional training and the embedding of NGO work in existing community practices; collaboration and contestation in relationships with the state; and being an efficient modern organization and one based on more traditional membership. 


\section{Organizational growth and institutional wrestling}

In this chapter, we take a pragmatist perspective on organizational learning, one that is distanced from the idea of an organization as a rational decisionmaker in search of maximal effectiveness, the view typical of management approaches to the subject (Lorino 2018). Pragmatist accounts rather provide definitions of organizational learning such as a "process that transforms an uncertain situation into a more settled situation", where new knowledge and habitual practices are jointly created (Brandi \& Elkjaer 2016, 149); this is one in which existing "organizational beliefs and practices become problematic" (Morgan 2014, 1047), and the "normal ways of doing things are disrupted because of surprises or unusual events that are difficult to comprehend and to deal with" (Rumens \& Keleman 2016, 13). We therefore define organizational learning as potential growth (Holma \& Kontinen, this volume) in organizational contexts which takes place in everyday practices in an organization when an encountered disruption triggers joint reflective inquiry. This inquiry is potentially characterized by democratic interaction among those involved, and leads to new, better practices, conceptualizations and habits.

In our framework, the notions of habit, disruption and community of inquiry (Dewey 1922/2012) are central. We understand habit as an "acquired predisposition" to respond in a certain way under certain conditions (Dewey 1922/2012, 20) due to repeated experience. In NGOs, habits can be materialized in organizational guidelines and plans, but they are also embedded in the implicit, taken-for-granted ways in which "we do things here", performed to the degree that they meet the needs of action in a specific situation (Morgan 2014, 1046). However, when such "normal" ways of doing things encounter disruptions, surprises or unusual events, doubt arises and existing habits become the focus of attention and reflection (Rumens \& Keleman 2016, 11; Lorino 2018, 81) - potentially in an organizational community of inquiry where negotiation and experimentation results in new, better ways of doing. In organizational contexts, a community of inquiry can refer to a group where both members and non-members participate in an attempt to address a shared task encountering a problematic situation (Rumens \& Keleman 2016, 11; Brandi \& Elkjaer 2016, 149). In NGOs, a community of inquiry can comprise the members of staff involved in certain tasks, but can also include beneficiaries, donors and other stakeholders insofar as interaction is characterized by democratic negotiation and experimentation rather than the imposition of one actor's agenda in face of a shared challenge.

We seek to combine the notion of organizational growth with that of institutional wrestling, in line with Brandi and Elkjaer (2016, 150-151) who suggest that negotiations in communities of inquiry within organizations are characterized by "wrestlings" between different ideas concerning the content or purpose of the organization's work. Drawing from Kontinen's (2018) elaboration of how organizational learning in development NGOs is intertwined with the need to align with institutional tendencies in search of legitimacy vis- 
á-vis different audiences, we suggest that many organizational tensions are manifestations of what we call institutional wrestling: that is, the need to balance between pervasive tensions and tendencies characteristic of organizational environments and the institutional field of development (Tvedt 1998; Lewis 2016; Cornwall 2007). These tensions can present disruptions to organizational practices which may be explicitly reflected within the organizational communities of inquiry; however, organizations cannot do away with these tensions merely by reformulating their own habits.

The development research literature has discussed a number of such tensions with which NGOs, especially those in the Global South, must wrestle. For instance, in countries that follow policies restricting their civic space (Hossain et al. 2018), NGOs have to define their purposes and activities in a way that ensures their chances of survival. Further, NGOs wrestle with their potentially dual role in society as contributors to incremental improvements in people's lives and as mobilizers of transformational change at a more systemic level (Mitlin et al. 2007; Choudry \& Kapoor 2013); they must also continuously balance between adhering to management practices aimed at effectiveness and measurement, and more human-centred approaches based on interaction and oral narratives (Claeyé 2014; Girei 2016; Dar 2014). Therefore, when NGOs emphasize one or the other approach explicitly, it gives rise to situations where they have to wrestle with the ensuing tensions. Consequently, we argue that, in the processes of organizational growth, the formulation of new habits is both enabled and constrained by the need for institutional wrestling. Therefore, in our understanding, growth and wrestles are not separate nor alternatives to each other, but intertwined in organizational learning processes.

\section{Introduction to ACFODE and methodology}

Action for Development (ACFODE) is a kind of success story among Southern development NGOs. It is a Ugandan organization established in 1985 to "stimulate, energise and catalyse action on women issues". ACFODE engages with national level advocacy in relation to gender aspects of legislation and policies, and implements community development programmes addressing gender inequality, currently covering all the regions of the country. ${ }^{2}$ The organization was started by a few concerned activists, many of whom were academics, in the aftermath of the UN's Third World Conference on Women in Nairobi in 1985. Since then, the NGO has established itself as one of the leading, all-inclusive ${ }^{3}$ gender advocacy organizations in the country. It has grown from a "hand-bag organization" 4 hosted in the office of one of the founder members at Makerere University to a professional organization that owns an office building and has a fully functioning secretariat. ${ }^{5}$ Probably due to the fact that many of the founder members were academics, knowledge production and dissemination have been high on the organizational agenda from the very beginning. The Arise 
Magazine, covering a range of gender-related issues, has been a consistent bi-annual publication since 1991, and ACFODE has produced a number of research reports and studies. As is common to many well-established NGOs in the Global South, the organization to date is highly donor-dependent, with almost 90 per cent of its budget covered by external funding. Longterm and constant support from its development partners, especially the Konrad Adenauer Foundation, has played an important role in ACFODE's organizational stability and success.

The research material collected from the NGO includes documents such as reports, field notes on organizational workshops conducted in November 2016 and April 2017, and individual interviews with members and members of staff $(n=12)$. In the first workshop the participants analysed significant events in the organization's history and discussed interaction with different stakeholders. After the workshop, individual interviews with selected staff and ordinary members were conducted. In the second workshop we presented a report based on the preliminary analysis of the material collected in 2016 in order to validate our interpretations and receive additional analysis.

For the purposes of this chapter, we read organizational documents and transcribed interviews and workshop discussions in an attempt to identify instances of "problematic situations" and the habits that were prevalent in these situations. Further, we identified potential changes in organizational practices as a consequence of reflecting on these situations, ${ }^{6}$ and the enduring tensions embedded in these instances of habit reformulation. Over a time span of 30 years, such instances were many. In what follows we discuss selected examples that illustrate the dynamics of growth and wrestling, first in this particular NGO and then in development NGOs in general.

\section{Complexity of the core concern: Dealing with patriarchal habits}

Management views of organizational learning emphasize the need for clear definitions, specific goals and measurable indicators. In contrast, the pragmatist perspective suggests that goals and strategies are always fallible and frequently changing, and that organizational learning should be examined in connection with more enduring but also unarticulated existential concern rather than explicit cognitive goals concerning what should happen in a near future (Lorino 2018, 83). The existential concern, or the core concern as we call it, refers to the fundamental reason for an organization's existence: what it seeks to achieve through a variety of explicit goals that change during its history. From the pragmatist perspective, the main question is not about polishing goals and measuring them, but about how an organization learns to promote its core concern in a flexible manner and in the best possible way in changing situations. For ACFODE, such concern has been related to gender equality which it has addressed according to different goals and a variety of strategies over the years. 
Claims that learning is more effective when goals in development NGOs are well-defined are challenged by the complex nature of typical core concerns related to social change. Development research has increasingly emphasized "messy realities", uncertainties and realistic views in development management rather than aspirations of linear change with well-defined goals (Davies 2005; Green 2016; Ramalingam et al. 2008, 65-66). ACFODE's core concern is a complex phenomenon in which biological, social, cultural, political, economic and legal elements intertwine and are impacted by different forms of power. One member depicted the learning to do with the core concern in the following way:

ACFODE's dream of transformation of the whole nation, with people changing their mind-set about women has not been realized. For example, gender-based violence is still rampant; women are working in the garden, [they] harvest crops, and when they sell, men get all the money and drink it out; when a wife complains, a husband beats her; when she asks money for the family, he says, "Shut up. You are only a woman, I paid for you". ACFODE is learning that this is still continuing, despite all its efforts for the last 30 years.

The above reflection illustrates common challenges and frustrations in NGOs devoted to social change and the realization of rights. While their visions mostly relate to radical transformations in oppressive structures and systems, as well as ensuring the realization of rights, they often see their results in incremental changes in welfare or service delivery and use. With its origins in the women's movement, ACFODE was eager to address what could be called patriarchy on a more systemic level. In interviews, members frequently repeated that ACFODE had, from the start, "a rights mantle, as opposed to a women's welfare mantle" (Arise 2015, 7). In the early years, it conducted welfare-related initiatives to facilitate women's empowerment under the existing conditions, such as providing bursaries for girls to go to school, or micro-loans to women to start small businesses. At a more systemic level, it influenced legislation review to take a gender perspective, and advocated placing women in leadership positions. However, the core concern of ACFODE is such that achieving it is beyond the control of any single organization given that it aspires to changing the attitudes and practices of so many "others": of individuals, communities, legislators and, further, cultures and social systems.

Thus, from the pragmatist point of view, organizational learning in ACFODE is geared to the question of how best to change the habits of others. In its strategic plans, the NGO frequently mentions deep-rooted gender inequalities "resident in socio-cultural practices". For example, as articulated in ACFODE's strategic plan for 2012/13-2016/17, one of its strategic objectives articulates an aim "to contribute to the reduction of sociocultural practices that cause gender-inequality". Often, culture as "knowledge 
and values shared by a particular society" is mentioned, and a distinction between negative and positive socio-cultural practices is made (ACFODE 2016, 6). The negative practices identified by ACFODE resonate with those observed in many other contexts: early and forced marriages, virginity testing, widow rituals, female genital mutilation and witch-hunting against women and girls (ACFODE 2015, 12). Gender-based domestic violence, rights to land ownership, and women's absence from decision making have also been among the practices addressed. ACFODE has seen gender inequality as an economic and political concern, not only a cultural issue.

From the pragmatist point of view, these socio-cultural, economic and political practices can be defined as patriarchal habits. Experience over generations has stabilized certain habits in gender relations, which limit the "imagination of people of doing otherwise" as it is "convenient to use the roads that are already there" (Dewey 1922/2012, 27). Therefore, the habits that for ACFODE were manifestations of undesirable gender inequality were not necessarily perceived as problematic in the communities. This reflects Dewey's $(1922 / 2012,44)$ suggestion that we should realize the full force of institutions as "embodied habits", and take into account their stability and resistance, which hinders "rapid and sweeping social change". The gendered cultural practices addressed by ACFODE are taken-for-granted, and rarely contested during the course of everyday life as "such practices persist because they are not questioned or challenged and, therefore, take on aura of morality in the eyes of those adhering and promoting them" (ACFODE 2015, 2). Sometimes, the force of habit was physically manifested when ACFODE staff members were harassed by local men who perceived them as importing a threatening message alien to local daily experience.

At times, the resistance has led to frustration, as the outcomes of the NGO's work are hard to identify and they occur across long time spans; little or no change seems to take place despite considerable efforts. In response, the organization has developed patience, practiced long-term planning and tried to be satisfied with "partial" success. It has also attempted to adopt a form of reporting that pays more attention to qualitative life stories indicating change than quantitative indicators. As one staff member comments with regard to the challenges of measuring the "success":

When you meet around 50 people, you'll get those who are championing [our cause], at least 15 [out of the 50]. But then the 35 are saying, "No, for us we believe in our culture; a woman is an assistant; a woman is just a worker, a woman isn't supposed eat from where you eat from." Now those are the 35; the 15 will say, "We can educate girls." The 15 will actually challenge and share; eh, they will always be champions. But the champions are always few. Yet even if out of ten you only get two, those two are enough; you would work with them because now the two will try to engage slowly with the eight and among the eight at least you will get four or five saying, "Yes, let's support this." 
When we look at ACFODE's organizational learning in relation to its core concern of gender equality, it becomes clear that learning to address such a complex and enduring phenomenon, one embedded in the institutionalized habits of others, means dealing with constant uncertainty and resistance. Therefore, in order to keep going, ACFODE has had to wrestle with the discrepancy between the desired goals of profound transformation in patriarchal habits and the incremental changes taking place in everyday lives, continually experimenting with different strategies in order to address the concern on different fronts. In the following section we discuss learning and changes in terms of actual practices geared towards creating a disruption in the habits of others.

\section{Changes in the habits of implementation: Embedding project activities in daily lives}

Modes of addressing its core concern have changed in ACFODE over time. In the beginning, the organization employed strategies that one of the members called "preaching". They were enthusiastic about educating women about their rights, empowerment and emancipation. In practice, the work in the communities included a lot of training. Typically, one or two active ACFODE members from Kampala, the capital city of Uganda, went out to the communities to provide a training workshop lasting a few days, to which local women were invited. These approaches, however, seemed to be problematic when it came to whether actual change took place in consequence, and whether the exercise reached the people whose cooperation was essential for transformation to take place.

Thus, notwithstanding the specific content of any particular project, the organizational habit of conducting training workshops encountered a range of challenges; for instance, women's attendance at training venues outside the community was problematic due to the difficulty of totally abandoning their daily household duties. Sometimes their husbands forbade their attendance; at other times they surprisingly appeared in the training venues along with all their children and baby-sitters. Inviting only women also created suspicion among men: "The works of ACFODE were misunderstood; people perceived it as inciting women against men, they misunderstood women's empowerment as teaching women to disobey". Moreover, an empowerment message delivered by "somebody from Kampala" was not always considered relevant in the community settings. Usually, the workshops resulted in considerable enthusiasm being generated among attending individuals whose new ideas, however, were constantly challenged by everyday practices, as discussed in the previous section:

It was new for them and the women were excited to know that they had such rights. But again the people who were violating their rights were not involved in the training from the beginning. So women would tell us, "Okay, you have told us it is our right to have a, b, c, but when we reach home these men violate them. What do we do?" 
From the pragmatist point of view, the disruptions that ACFODE encountered in its training approach exemplify the challenges to changing institutionalized habits formed by long-term practice more generally; they do not reside only in individual conceptualizations but are also incorporated into action and circumstances. ACFODE's experience resonates with Dewey's (1922/2012, 12-13) reflections that "we cannot change the habit directly, but we can change it indirectly by modifying conditions", and further, "we must work on the environment, not merely on the hearts of men". For development NGOs, this implies that the strategy of training individuals is not sufficient to bring about enduring social change. While increased information is needed, actual change requires a more holistic approach. ACFODE has reflected on this disruption after observing that a training approach might not be the best possible way forward, and has reformulated its educational initiatives in ways that a member described as "conducting workshops to go where people are". Today, while the organization continues to provide structured training events, it has also increasingly introduced educational models such as dialogues conducted within the communities, "just under the tree". Moreover, soon after the workshops commenced, men were also invited to take part in training sessions, and later, a more comprehensive idea of the "strategic engagement of men" was introduced. Implementation strategies, such as promoting "model couples" of gender equality to be examples in communities, were adapted, and the enrolment of cultural and religious leaders started. Thus, the activities promoted by the NGO were increasingly embedded in existing daily practices and social power constellations in communities instead of being conducted as separate events.

Another disruption experienced by ACFODE was related to the form and content of the message delivered. The fact that most of its community projects across Uganda were funded by foreign donors and international NGOs and used across Uganda, meant that much of the training material used was originally produced outside the country and was in English. In practical training situations, the staff realized that sometimes the materials were useless because community members did not understand them at all. In order to address this, ACFODE staff took the initiative to find extra resources, as well as convincing current donors to fund the translation of material into local languages. Yet the challenge was not only due to language, but also to content. ACFODE realized that at times too much prior knowledge was assumed of the participants. For example, the training materials on democracy and good governance for local women councillors started with a depiction of the birth of democracy in "ancient Greece" - a place that had little resonance with the experiences of participants. Moreover, at the beginning of another capacity-building project for women councillors, it was realized that many of them "did not even know how to read and write", highlighting the pressing need to change approaches.

These examples illustrate problematic situations ACFODE encountered in its attempts to address its core concern through training approaches. In the 
face of these disruptions, ACFODE staff and its members have actively reflected on and experimented with better ways, continuously reformulating its organizational habits of project implementation in the communities - not only through discussion among staff members, but also in negotiation with beneficiaries and donors. During the interviews, ACFODE staff gave credit to both "vocal" beneficiaries' open critique of approaches that do not work and "flexible" donors who were ready to adjust project plans, without which reformulation would not have been possible.

\section{Changes in advocacy approaches: Balancing between survival and impact}

As part of the emerging Ugandan women's movement in the late 1980s, ACFODE was involved in many activities that today would be labelled advocacy. These included lobbying the newly formed National Resistant Movement (NRM) government to appoint women to government bodies, advocating the improvement and restructuring of national networks for women, engaging actively in the constitution-making process and contributing to affirmative action that ensured special seats for women at every level of governance. At that time, the NRM government offered a conducive and supportive environment for the women's empowerment agenda. However, it was soon felt that the NRM and President Yoweri Museveni himself wanted to be seen in the "driver's seat", which somewhat sidelined the significance of the women's movement (ACFODE 2010, 79). Moreover, developments within the political environment and the introduction of multiparty politics in Uganda in the late 1990s changed the government's attitude to one of suspicion and confrontation. When operating during the time of a one-party - or non-party - regime, ACFODE did not question political power relations while advocating women's rights (Tripp 2001), but its role changed in parallel with changes in broader state-civil society relations, while changes in international development discourses affected ACFODE's project portfolios. Issues of women's empowerment were accompanied by questions of human rights and good governance; thus, desirable transformations of interest expanded from the rebalancing of asymmetric gender relations to overall democratization and realization of human rights.

In the changed situation, habits of mutual collaboration with the NRM no longer worked. For example, ACFODE became increasingly dismissed as an elitist organization: "You would hear government officials asking, who you speak for anyway?" The NGO responded to the challenges by adopting advocacy strategies such as bringing members of rural communities to meet decision-makers to lobby for themselves instead of lobbying on their behalf. They also invested in knowledge production, documentation and dissemination in order to base their advocacy on facts and evidence. A strategy of joint advocacy, networks and coalition building with other NGOs has also been critical in a hostile political environment; meanwhile coalitions ${ }^{7}$ have likewise 
strengthened the power to influence and facilitate collective positions on key gender issues, offering women leaders safe fora in which to discuss their challenges and seek collective support in cases of political backlash. Networks have been crucial in protecting the organization while advocating and lobbying on "politically sensitive" issues.

The current relationship between NGOs and the government in Uganda comprises a continuous balancing act between collaboration, co-optation, control and confrontation. Consequently, ACFODE needs to walk a fine line between advocating democracy and having a non-partisan identity, as required by the NGO Act of 2016. For instance, during awareness training in communities about general elections, ACFODE emphasizes the need for voting a competent woman, while it avoids supporting any particular party. The same applies to the training of women caucuses established in local councils: "We said no, as women councillors we are all representing women, we are not representing parties; you are representing women's issues." At the local level, ACFODE's efforts to educate ordinary citizens to claim personal rights, state accountability and good governance were often considered threatening and perceived as anti-government activity. As noted above, in the early days, ACFODE used to go straight to the communities, but this approach became problematic and they explicitly changed their ways of collaborating with the local government sector. As one of the members of staff reflected, "They need to know, even if you are not inviting [the government officials], there will be security people around, listening to what you are saying." More recently, ACFODE has put constant effort into incorporating the organization's actions into local government activity plans by signing Memoranda of Understanding (MoUs) and inviting government officials to attend training events and community dialogues. As one of the interviewees explained, "You should at least pay a visit to their offices. Even if you don't find them there, you can deliver an information pack." This is a prerequisite for being able to function, as in some instances a failure to disseminate relevant information has led to the abrupt suspension of training activities by officials.

Whether ACFODE has advocated on issues to do with electoral processes, public financing or holding leaders accountable, its strategy has always been geared towards advancing its core concern: gender equity and equality. The core concern has also been affected by changes in international debates on gender and development. Meanwhile, affirmative action (e.g. special seats reserved for women), strongly advocated by ACFODE in the early years, has been challenged by the fact that while it provides political opportunities for marginalized groups, it simultaneously strengthens the political power of the authoritarian regime; for instance, the special "women's seats" are easily coopted by the ruling party (Muriaas \& Wang 2012). Furthermore, overall "gender mainstreaming" - on ACFODE's agenda for a long time - has encountered critique on the basis that it domesticates and hampers the transformative potential of feminism (Cornwall et al. 2004; Davids et al. 
2014). Indeed, ACFODE has been criticized by radical activists who claim that its reformist strategies scarcely address deep-rooted, oppressive, gendered power structures but, rather, continue to entrench them further. Moreover, some international NGOs have demanded that ACFODE take a more transformative stance and confront the authoritarian government. These debates illustrate, once again, the continual wrestling between supporting incremental or transformational change that NGOs undergo. While ACFODE has learned to reformulate its organizational habits when advocating its core concern of gender equality, it has simultaneously wrestled with survival as a civil society organization in a semi-authoritarian regime that requires constant balancing between transformation and reformation, and between contestation and co-optation.

\section{Reformulating the ways of being an organization: Organizational restructuring}

As with any major change, the prospect of letting go of the old and concretizing the new ACFODE was greeted with anxiety, scepticism and even fear. Members had grown fond of ACFODE and they identified with her story. It was their story; it seemed, to many of them, that changing ACFODE would be like stripping naked and losing the identity that no doubt had been entrenched in their minds over a long period. It was painful to accept that the character and personality of ACFODE that they had come to cherish had to change.

(ACFODE 2010, 65)

The process of reformulating habits of being an organization relates to the critical discussion of the professionalization and modernization of Southern NGOs in light of donor demands and global managerialism trends (Banks et al. 2015; Girei 2016). ACFODE's experience of organizational restructuring seems like a typical example of adaptation to donor demands; however, a closer look at the process provides a more nuanced picture. A model of the best ways to organize was not simply imported to ACFODE with any single donor capacity-building initiative, but also resulted from continuous self-reflection which started in the NGO's early years. The vocabulary used at the beginning of the 1990s by leadership, staff and general membership embraced openness and a willingness to learn from mistakes, and stemmed from both internal and external environments. Language like, "to continue the struggles, add more firewood and blow harder, so that the founding fire does not go out"; "re-engineering"; "shedding off old skin"; "coming of age"; "pruned off removable buds", "period of refinement"; and "identifying strategic spots" is found in most of the organization's publications around that time. The outgoing chairperson's hand-over reports (ACFODE 1997) provided a frank assessment of organizational experiences and the need for "re-engineering" in order to become a more effective organization in terms of gender advocacy. Different, gradually accumulated challenges triggered an organizational restructuring process implemented in 2000. 
The restructuring process addressed a number of organizational habits experienced as problematic; one concerned the use of the office building. Members frequently convened in the premises, perceiving it as their "living room". At the time, ACFODE used its members in its programme implementation. Thus, members came to the office to inquire about the possibilities of fieldwork assignments, but also to conduct their personal activities using the NGO's facilities, or just to socialize and meet other members. This led to a difficult situation in which organizational resources such as water and electricity were overused, and office tasks were not effectively accomplished while considerable time was spent in general socializing. Secondly, ACFODE had the habit of being a "fire-brigade". In the early years of the new Ugandan women's movement, ACFODE, as one of the very few local women's organizations, tried to be everywhere and address every issue related to gender equality, carrying out a variety of activities on an ad hoc basis with short-term donor funding. These activities seemed not to work in the long run, and beneficiaries were not satisfied with limited short-term attention. Moreover, "being everywhere" led to minimal overall impact. The establishment of a number of other gender NGOs enabled specialization, while changes in external circumstances, especially in donors' strategic foci, hindered the continuation of specific activities such as bursaries and microcredits.

In these changing circumstances, habits formulated during the organization's early experiences seemed not to work anymore. Encouraged by one of their donors, Hivos, ACFODE decided to go through a total restructuring process led by a Change Process Management Team (CPT) made up of representatives from among the general members, the executive board and staff, as well as an external consultant from a well-known organizational development institute in Tanzania. The process took months and included participatory workshops and negotiations. As a result, the organization structure was revised from units to programme committees; the Board was "re-engineered into a non-executive one that was more policy-oriented"; the vision, mission, core purpose, mandate and strategic objectives were revised to focus more on advocacy than service delivery; and the new focus was articulated in organizational artefacts such as strategic plans that guided long-term work.

During the restructuring, the position of members also changed. Their involvement in project implementation was to be based on qualification and competence, not only on willingness - with recruited professional staff taking on most of it - and their use of office space and equipment was restricted. While restructuring the $\mathrm{NGO}$ was considered inevitable if ACFODE were to be able to address its core concerns, it called for balancing between different ideas of what constitutes a good and proper organization. In a number of interviews members remembered the "good old times" of wide-spread enthusiasm and member-engagement in field assignments: 
Before, when there was an activity, maybe in eight or ten districts, we were setting off on the same day ... . and each district is taking a minimum of three people. You find that twelve people would be setting up at six in the morning going down to the South, West, a few going to North, so you all would go . . . Now, a whole project might only take up like maybe four people from the membership, the rest would be staff.

Overall, ACFODE repositioned itself as an efficient, professional organization with a core purpose of "advocacy for gender equality and equity", a clear structure and a staff recruited on the basis of competence in both substance and project management. The current organization aligns with the global model of a "modern organization" that follows the principles of rationality, has explicated goals, explicit borders, and tracks its use of resources (Bromley \& Meyer 2017; Meyer \& Bromley 2013). However, it is still torn between - and wrestles with - being an open-for-all space for members and an organization with specific borders, as some of the initial sense of belonging and solidarity has been lost. It also encounters contradictory tendencies from the donor community due to its being simultaneously in accordance with the requirements but at the same time subject to the critique of being "too professional" to be able to address the needs of communities (Banks et al. 2015). The latter trend has surprised the organization, as one informant noted, "If I was . . . an NGO in the northern hemisphere, I would be happy to work with a professional organization because you know your resources will be effectively used." Overall, restructuring was not a one-off exercise, and the NGO continually seeks to maintain close relationships with its members and the communities with which it works, through participatory processes of designing organizational strategies, among other means.

\section{Conclusions}

Based on our analysis of ACFODE, we can summarize four types of interplay between organizational growth and institutional wrestling. We began by demonstrating the multi-faceted nature of ACFODE's core concern. As organizational learning is geared towards finding the best possible ways to address core concerns, development NGOs must consider the complexity of social change in their efforts to transform social habits. Further, they continuously encounter situations in which their approaches do not work as expected, thereby giving rise to uncertainty as to best practice. Second, we showed how NGOs can learn during the implementation of their projects, in this case by shifting from training approaches to those more embedded in people's daily practices. Third, we provided an example of how NGOs have to learn to change their advocacy strategies in political environments that are becoming more restrictive. Fourth, we scrutinized how NGOs learn to be modern organizations with explicit borders, measurable goals and competence-based division of labour, in contrast to more informal, membership-based operating principles. 
All these instances resonate with the idea of organizational learning as growth. In these examples, ACFODE encountered situations in which its taken-for-granted ways of working did not function: the training approach did not bring about the desired change in gender relations; collaboration with the NRM became difficult in the changed political environment; and perceptions of the NGO as an open space benefiting all its members was considered problematic in terms of resource use and loss of focus. Throughout the process, ACFODE showed the ability to learn, forming communities of inquiry that addressed these situations either internally, or with other NGOs, beneficiaries and donors, and jointly searched for better ways to operate. This was supported by ACFODE's continuous commitment to its core concern. While it reformulated its project implementation practices, advocacy approaches and ways of being an organization, it retained gender equality as a guiding principle. Encountering problematic situations, ACFODE initiated reflection, followed by negotiation of, and experimentation with, better ways to address gender inequalities. Thus, we contend that organizational growth was the prevailing response to problematic situations.

However, the processes of organizational growth were also characterized by institutional wrestling. As one of the ACFODE members asked in our feedback seminar:

All these learnings, do we really want them? . . . If a development partner says that they are restricting your finances, we have to react to that - but is that a positive learning process?

In an ideal process of organizational growth, the organization would be able, through negotiation and experimentation, to identify the best possible ways to address its core concern in the context of changed circumstances. However, as our case study shows, formulation of new ideas and practices are constrained by institutional tensions, unsolvable by any single organization. These included the restriction of NGO activities by project models that often include the implementation of training events that can be counted for the purposes of reporting; the compromises made to transformative agendas both in order to survive in a political environment restrictive for civil society organizations and also be accepted in communities resistant to their main messages; and the loss, on professionalization, of some of the feelings of belonging and solidarity characterizing membership-based organizations. Therefore, we conclude that organizational learning in NGOs requires the tolerating of continuous uncertainties while navigating between a variety of demands and interests. At the same time, the organization needs to be faithful to its core concern. Organizational learning, thus, is not so much about defining objectives and measuring the achievement of ideal goals, but, rather, a continuous engagement with practices and a readiness with ongoing response to problematic situations and joint experimentation of novel ways of doing things. 


\section{Notes}

1 The first author is the principal contributor to the conceptual discussion and participated in the data collection in the NGO together with the second author. The authors contribute equally to analysis and writing up the findings.

2 These include, in the Central Region: Kiboga and Mubende; in Karamoja Region: Kaabong, Kotido and Moroto; in Westnile: Nebbi and Yumbe; in Northern Region (Acholi Sub-Region): Pader; in Lango Sub-Region: Apac, Dokolo, Kole and Oyam; in Eastern Region: Namutumba; and in South-West Region: Kanungu and Kisoro Districts.

3 ACFODE membership includes all women without discriminating on the basis of age, education level, employment status, personality, etc. While it started as a women-only organization, in the course of restructuring processes, it has admitted like-minded men as members as well.

4 One of the first members narrates how, in the beginning, all organizational assets such as documents were kept in members" "handbags" (ACFODE 2010, 10).

5 By 1997, ACFODE's Secretariat was headed by an executive secretary with 17 support staff.

6 We illustrate our analysis with direct quotes from the material. When the quote is from a document, a source is explicated. Other quotes are from individual interviews and workshop discussions and the speaker is not identified in order to ensure anonymity.

7 For instance, networks such as the Coalition on the Domestic Relations Bill (DRB) whose main objective was to lobby the government and other stakeholders for a just domestic relations law to be passed; the Uganda Women's Network (UWONET) which is an advocacy and lobbying coalition of national women's NGOs and institutions in Uganda; the Uganda Land Alliance whose mandate is to advocate fair laws regarding women's ownership of land; and the Coalition for Political Accountability to Women (COPAW).

\section{References}

ACFODE (1997). Hand-over report by Dr. Joy C. Kwesiga (1993/1995 and 1995/ 1997). ACFODE.

ACFODE (2010). 25 Years. A shattered dream gave birth to ACFODE's incredible journey (Printed report to celebrate ACFODE's 25th anniversary).

ACFODE (2015, December). Culture, gender and development. Strengthening institutions to promote gender responsive social cultures (PRO-GERESOC) (Project Newsletter). ACFODE.

ACFODE (2016). Culture, gender, and development. Promoting positive socio-cultural practices in Lango sub region (PRO-GERESOC) (End of Project Newsletter). ACFODE.

Arise (2015). Celebrating a journey of passion for a just society. ACFODE 30 years. Arise: A Women's Development Magazine Published by ACFODE, 2015(59), 1-68. Retrieved from www.kas.de/c/document_library/get_file?uuid=c5cf4e46-28f9-093a -33a5-a313c56ea4e8\&groupId=252038

Banks, N.D., Hulme, D. \& Edwards, M. (2015). NGOs, states, and donors revisited: Still too close for comfort? World Development, 66, 707-718.

Brandi, U. \& Elkjaer, B. (2016). Organizational learning: Knowing in organizing. In M. Kelemen \& M. Rumens (Eds.). American pragmatism and organization: Issues and controversies (pp. 147-161). London: Routledge. 
Bromley, P. \& Meyer, J.W. (2017). They are all organizations: The cultural roots of blurring between the non-profit, business and government sectors. Administration and Society, 49(7), 939-966.

Chambers, R. (1997). Whose reality counts: Putting the first last. London: Intermediate Technology Publications.

Chambers, R. (2017). Can we know better?: Reflections for development. Rugby: Practical Action Publishing.

Choudry, A. \& Kapoor, D. (2013). NGOization: Complicity, contradictions and prospects. London: Zed Books.

Claeyé, F. (2014). Managing nongovernmental organizations: Culture, power, and resistance. New York, NY: Routledge.

Cornwall, A. (2007). Buzzwords and fuzzwords: Deconstructing development discourse. Development in Practice, 17(4/5), 471-484.

Cornwall, A., Harrison, E. \& Whitehead, A. (2004). Introduction: repositioning feminism in gender and development. IDS Bulletin, 35(4), 1-10.

Dar, S. (2014). Hybrid accountabilities: When western and non-western accountabilities collide. Human Relations, 67(2), 131-151.

Davids, T., van Driel, F. \& Parren, F. (2014). Feminist change revisited: Gender mainstreaming as slow revolution. Journal of International Development, 26, 396408.

Davies, R. (2005). Scale, complexity and the representation of the theories of change. Evaluation, 11, 133-149.

Dewey, J. (2012). Human nature and conduct: An introduction to social psychology. Digireads.com Publishing. (Original work published 1922).

Easterby-Smith, M. \& Lyles, M.A. (Eds.). (2011). Handbook of organizational learning and knowledge management. Chichester: Wiley.

Ebrahim, A. (2005). Accountability myopia: Losing sight of organizational learning. Nonprofit and Voluntary Sector Quarterly, 34(1), 56-87.

Eyben, R. (2006). Relationships for aid. London: Earthscan.

Fowler, A. (1997). Striking a balance: A guide to enhancing the effectiveness of nongovernmental organisations in development. London: Earthscan.

Fowler, A. (1998). Authentic NGDO partnership in the new policy agenda for international aid: Dead end or light ahead? Development and Change, 29(1), 137-159.

Fowler, A. (2000). The virtuous spiral. A guide to sustainability for NGOs in international development. London: Earthscan.

Girei, E. (2016). NGOs, management and development: Harnessing counter-hegemonic possibilities. Organization Studies, 37(2), 193-212.

Green, D. (2016). How change happens? Oxford: Oxford University Press.

Hayman, R., King, S., Kontinen, T. \& Narayanaswamy, L. (Eds.). (2016). Negotiating knowledge: Evidence and experience in development NGOs. Rugby: Practical Action Publishing.

Holma, K. \& Kontinen, T. (2019). Practices and habits of citizenship and learning. In this volume.

Hossain, N., Khurana, N., Mohmand, S., Nazneen, S., Oosterom, M., Roberts, T., Santos, R., Shankland, A. \& Schröder, P. (2018). What does closing civic space mean for development? A literature review and proposed conceptual framework (IDS Working Paper 515). Retrieved from www.ids.ac.uk/publication/what-doe s-closing-civic-space-mean-for-development-a-literature-review-and-proposed-con ceptual-framework 
Kontinen, T. (2018). Learning and forgetting in development NGOs. Insights from the organizational theory. Oxon: Routledge.

Lewis, D. (2016). Abandoned pasts, disappearing futures: Further reflections on multiple temporalities in studying non-governmental organisation worlds. Critique of Anthropology, 36(1), 84-92.

Lorino, P. (2018). Pragmatism and organization studies. Oxford: Oxford University Press.

Meyer, J.W. \& Bromley, P. (2013). The worldwide expansion of "organization". Sociological Theory, 31(4), 1045-1053.

Mitlin, D., Hickey, S. \& Bebbington, A. (2007). Reclaiming development? NGOs and the

challenge of alternatives. World Development, 35(10), 1699-1720.

Morgan, D.L. (2014). Pragmatism as a paradigm for social research. Qualitative Inquiry, 20(8), 1045-1053.

Muriaas, R.L. \& Wang, V. (2012). Executive dominance and the politics of quota representation in Uganda. The Journal of Modern African Studies, 50(2), 309-338.

Ramalingam, B., Jones, H., Toussaint, R. \& Young, J. (2008). Exploring the science of complexity: Ideas and implications for development and humanitarian efforts (ODI Working Paper 285). Retrieved from www.odi.org/sites/odi.org.uk/files/odi-assets/p ublications-opinion-files/833.pdf

Rondinelli, D.A. (1993). Development projects as policy experiments: An adaptive approach to development administration. London: Routledge.

Rumens, N. \& Kelemen, M. (2016). American pragmatism and organization studies: Concepts, themes and possibilities. In M. Kelemen \& N. Rumens (Eds.). American pragmatism and organization: Issues and controversies (pp. 3-24). London: Routledge.

Senge, P. (1990). The fifth discipline: The art and practice of the learning organisation. New York: Doubleday.

Tripp, A.-M. (2001). The politics of autonomy and cooptation in Africa: The case of the Ugandan Women's Movement. The Journal of Modern African Studies, 39, 101-128.

Tripp, A.-M. \& Kwesiga, J.C. (2002). The women's movement in Uganda: History, challenges, and prospects. Kampala: Fountain Publishers.

Tvedt, T. (1998). Angels of mercy or development diplomats: NGOs and foreign aid. Trenton, NJ: Africa World Press. 


\title{
13 The crafting of "critical education" Experiences of a Ugandan NGO
}

\author{
Twine H. Bananuka and Vaughn M. John
}

\section{Introduction}

Over the past half a century non-governmental organizations (NGOs), as part of broader Civil Society Organizations (CSOs), have become an indispensable force in international development, particularly in the Global South. In Uganda the number has risen from 200 in 1986 to over 13,000 in 2015, although the reasons for such rapid growth are contested. Muhumuza (2005), for instance, credits it to the conducive environment ushered in by the National Resistance Movement (NRM) government; on the other hand, Makoba (2002) attributes it to state failure to provide essential social services, resulting in NGOs' filling the gap left by government.

Most NGOs in the Global South describe their work as community development with a focus on education. Although literature links community development to adult education (Beder 1989; Brookfield 1984; Lovett 1972; Niederfrank \& Cole 1972; Spence \& Wolff 1953), it falls short of describing the dynamics of the relationship: that is, how it emerges, develops and is sustained. Moreover, many NGOs commit themselves to critical education characterized by aims such as empowerment (Chilisa \& Preece 2005), conscientizing (Freire 1972) and liberation (Nyerere 1973; 1982). In this chapter, drawn from a larger case study (see Bananuka 2014), we address the relationship dynamics of adult education and community development by analysing the process of designing and implementing a kind of critical education in the Emesco Development Foundation (EDF), an indigenous rural-based NGO in mid-western Uganda.

This chapter therefore offers a narrative of how critical education emerges, how it is realized and the kinds of constraints it faces. Critical education in the EDF, while not planned in any deliberate manner, appears to have evolved in response to shifts in the role of the NGO from a provider of resources to a capacity builder in the community. We begin with a historical purview of the EDF and its objectives and then briefly discuss the context in which it is positioned. This is followed by examination of the elaborate process of changes and shifts that has produced the type of critical education in play. We conclude the chapter by showing how the multiple contexts of the EDF have shaped the kind of critical education it espouses. 


\section{The making of the EDF}

The Emesco Development Foundation (EDF) is an indigenous non-governmental organization located in mid-western Uganda near the border with the Democratic Republic of Congo (DRC). It was founded in 1998 in this rather remote and neglected area by a young Ugandan couple who were fortunate to have benefited from university education and who dreamed of contributing to the socioeconomic transformation of their area. The major goal of the EDF was thus to tackle the challenges of the local people in terms of preventable diseases and ill-health, extreme poverty, water scarcity and hunger. It hoped to realize socio-economic transformation through the creation of a social enterprise, that is, a micro-finance scheme from which "poor" ${ }^{1}$ people could borrow money at very low interest rates to invest in various projects. This scheme was based on an understanding that providing resources alone would lead to socioeconomic transformation, yet it faced a number of challenges, including the failure to repay loans. Some people borrowed and spent the funds on non-profit-making ventures such as marriage ceremonies and burials, while those who invested in agriculture faced the challenges of unreliable output resulting from bad weather and other vagaries of nature such as pests and diseases.

The above state of affairs compelled the EDF to rethink its community development strategy. It became clear that the founders had not properly diagnosed the communities' challenges, interests and capacities. Like many NGOs, the EDF's initial strategy was influenced by modernization development theory which holds that poor people are poor because they lack the knowledge and resources to better their lives (Youngman 2000; Zapf 2004). Despite the good intentions of the founders, they seemed not to have paid sufficient attention to the complexities of community development and to the peculiarities of the context. Realization of this caused the EDF to rethink and develop a new strategy, changing its focus to become a multi-sectoral development agency. In a bid to ensure integrated community development, micro-finance was followed by three programmes in the fields of agriculture, health, water and sanitation. The view of the founders was that agricultural improvement coupled with a healthy population in a hygienic environment would translate into socioeconomic transformation. Thus, over the years, the EDF shifted from a microfinance venture into an accomplished community development organization spanning the three districts of Kibaale, Kagadi and Kakumiro. It has since earned respect both nationally and internationally. Yet, despite switching from micro-finance to multi-sectoral development, it still had to deal with the complexities of providing a range of resources and advice to spur socioeconomic transformation. Linking up with development partners made it possible for the EDF to provide the vital resources for communities. In agriculture, the focus was on basic equipment such as farm tools, pesticides, seedlings and fertilizers; in the area of health, securing drugs was a priority, while in the field of water and sanitation an emphasis was placed on creating bore holes and shallow 
wells, mosquito nets and water tanks. Further reflection also made it apparent that resources alone were not the real challenge in the communities, but rather the lack of knowledge or ability to translate available and additional resources into solutions to their problems. This realization gave birth to a programme of adult education in the EDF which, as we show below, came to reflect some of the basic tenets of critical education.

\section{The multiple contexts of the EDF}

In order to understand the EDF's work and development strategy, it is necessary to grasp the multiple layers of context in which it is located: that is, the local communities, the government (local and central) and the international community (donors and global campaigns and policies). To begin with, the members of the local communities which the EDF seeks to develop and transform are largely small-holder peasant farmers engaged in subsistence agriculture. Kibaale district, which has since been split into the three districts of Kibaale, Kagadi and Kakumiro, occupies the former "lost counties" of Buyaga and Bugangaizi, ${ }^{2}$ and is subject to unstable and contestable land ownership. The issue of absentee landlords stretches back to colonial times when the British ceded large chunks of the Bunyoro kingdom to the Buganda kingdom in return for the latter's support of colonialism (Asiimwe \& Nolan 2001; Kuhanen 2000; Rugadya 2009; Rulekere 2006). Many people are squatters on the land they occupy and for this reason have limited economic rights over it.

These districts have a rich cultural mix with a combination of ethnicities including indigenous Banyoro and largely immigrant Bakiga from south western Uganda. Other groups include Baganda, Banyankore, Bafumbira and Banyarwanda from Rwanda and from the neighbouring DRC. In spite of the differences in ethnicities, these communities are comparable in many ways. They are highly conservative, with religion being core to societal values; Catholicism is the dominant faith followed by Anglicanism. By virtue of geographical location, Banyoro culture, which is patriarchal in nature, is dominant in the area. Therefore, great respect is accorded to men as family heads and overseers of resources (Bananuka \& John 2015).

The government must be seen as another core element of the context. By law, all NGOs in Uganda should be registered with the government and must detail all their activities and sources of funds. Due to the growing number and influence of NGOs, the government has tightened the rules governing them. Among others, all NGOs are required to declare their sources of funds and also renew their operational licences annually. Locally, NGOs are required to submit their work plans to the local government. This implies that the survival and successful operation of any NGO, including the EDF, requires good relations with the government. Like most NGOs (Sanders et al. 2012; Banks \& Hulme 2012), the EDF provides some essential services that would otherwise be the responsibility of the government, such as building school 
classrooms and providing safe water. The EDF requires government permission for such activities, and follows the government-set standards. Therefore, the government has grown into a critical stakeholder in the work of the EDF and its influence is evident from planning to evaluation. It is therefore not surprising that many local people struggle to distinguish the EDF from the government.

The third core component of the EDF's context is the international community, largely represented by the donors from the Global North who finance the EDF's programmes, as a result of which it has to contend with certain conditions (Makoba 2018). In order to tap into such funding, the EDF works to align itself with international protocols and proclamations such as the Millennium Development Goals (MDGs) and recently the Sustainable Development Goals (SDGs). Additionally, in order to enter such partnerships, it must be able to manage its projects according to hegemonic international models (Contu \& Girei 2013). Thus, the EDF's operations sit at the intersection of local culture, national and government obligations, and international proclamations and funding guidelines, all of which constitute influential contextual forces on the programmes and philosophy of the EDF.

\section{The emergence of critical adult education in the EDF}

In general, critical education refers to approaches rooted in critical theory and other radical philosophies. Its central aim is to empower learners to question and challenge dominant power centres and structures (Major \& Mulvihilland 2009; Freire 1972; Nyerere 1973; 1982), while its most profound foundation is that education is a political process characterized by power imbalance between the educator and the learner that should be dismantled (Farrow 2017; Foley 2001; Holst 1999; 2009). Paulo Freire (1972), one of the founders of critical pedagogy, speaks of conscientizing education and Julius Nyerere (1973), when positioning the main ideas of critical education in the contexts the postcolonial nation-building in Africa, uses the term liberating education.

Critical education was ushered into the EDF as part of its broader shifts and changes from a social business enterprise focussed primarily on financial resource provision to a multi-sector development organization offering a range of resources, and finally, an adult education-led development organization. As often discussed in the literature, community development is coterminous with adult education (Niederfrank \& Cole 1972; Nyerere 1973; VanDer-Veen \& Preece 2005) and, since its founding, the EDF has come to realize that community development is indeed an educational process.

It is important to note that because adult education was not initially among the major objectives of the EDF and nor were the founders and managers' educationists, there was no explicit educational agenda or educational system in place. The NGO reported that three years into its work, it was necessary to change focus because it was not realizing its intended goal of 
socioeconomic transformation. When asked why the EDF suddenly had to prioritize education in its work, one member of senior management had this to say:

I think, for us, adult education is a tool for achieving our community development goals. There is virtually no work that we do where we don't have [adult] education as a main component. To us, adult education is a key [emphasis added] to our community development agenda because it helps us to deliver the messages to the farmers and communities.

(Kwaga, a social worker by training)

Another member of senior management also noted:

In the beginning, we would go to the community and would really be giving lectures to community members about what needs to be done, what we see the community is like, what we feel the community needs to do or improve and things like that. We would be looking at the resources. But we came to realize that the resources are within the community: land, human resources, their knowledge and ideas.

(Paulo, an agriculture officer by training)

It is evident that the EDF started to see adult education as a "missing link" in their community development endeavours. The question that then followed and confronted the EDF was the type of education that could best lead to meaningful transformation. The findings of the case study on the EDF indicated that education and, further, of a type which would fully engage the community and connect with their world was what was needed. Other descriptions of education from stakeholders in EDF included the terms "a key" and "sustainability strategy". This growing awareness of the role of education in the realization of socioeconomic transformation gave rise to the following educational practices: retooling of staff, attending to indigenous knowledge, the conception of Community Development Workers (CDWs $)^{3}$ and the adoption of dialogic facilitation methods. Combined, these elements contributed to the emergence of "critical education" in the EDF, as discussed in detail below.

When the EDF decided to change its focus from resource provision to education as the main driver of socioeconomic transformation, it became necessary to venture into new territory in terms of its staff knowledge and skills. The EDF had initially recruited professionals in the fields of agriculture, health, water and sanitation and social work. Among the staff, there was only one health worker who had acquired an international certificate in adult learning facilitation, who was fondly referred to by colleagues as the "Pan African facilitator". He was later to act as the springboard for adult learning and education mentorship of colleagues. The EDF also took a 
decisive step to retool all staff with adult facilitation skills, preferring to retrain rather than recruit new staff in line with the changed focus because it felt that both technical and adult learning and education skills were required for integrated community development. Adult learning and education was now a tool to engage the community in the areas of agriculture, health education, income generation and water and sanitation. This type of retooling to create multi-skilled personnel is what Nyerere $(1982 ; 1973)$ calls the development of generalists in adult education.

The EDF's second seemingly critical education practice was to pay attention to indigenous knowledge. Many community development efforts are rooted in modernization development theory which posits that people are poor and backward because they lack the knowledge and skills to better their lives (Youngman 2000), thinking that was also reflected in the EDF's earlier community development approach, as noted above. The EDF had initially thought to have "correctly" diagnosed the problems of the people in Kibaale as lack of financial and material resources. The over-reliance on technical experts also implied that the kind of knowledge that the communities in Kibaale possessed was inferior and could not be relied on for socioeconomic transformation, which required some form of expert knowledge supplied by universities or advanced societies (Babikwa 2004). The EDF later realized that local people and communities possessed important indigenous knowledge which was vital for their own development: a big breakthrough. This enabled educational processes similar to those Freire (1972) calls conscientization: that is, awaking local knowledge and the power of local people. The following comments from two EDF staff members illustrate the rationale behind paying attention to indigenous knowledge.

Learners have much more experience than us [staff] who have been in school [formal education] . . you have a diploma in agriculture but have never done farming before . . . but these people know from experience. They can tell you that in such a season if you do not plant early, your crops will die because of less rain ... He [the farmer] knows this practically because he has done it before and did not gain from it. So the information we get from the village is useful to us as staff and management.

(Mendo)

Obviously the relationship between these adult learners [local people] and those students in school is not the same because here we share information ... in teaching you just come and give your information to the people and the people you are teaching ... But here [EDF] we assume that these adults know something, and as an educator, you are just adding to what they know. 
The EDF's decision to tap into indigenous knowledge has led to greater harmony with the local communities, with the staff realizing that the learning process should be mutual and not one way. This is what Busingye (2011) calls "tapping into the learners' knowledge reservoir". The EDF abandoned the know-it-all attitude of technist ${ }^{4}$ or expert development workers operating according to modernization theory (Babikwa 2004; Youngman 2000). The new approach now matches the cultural adage common in greater western Uganda that "obukuru magezi" (age comes with knowledge).

Relatedly, tapping into indigenous knowledge led to the conception and introduction of paralegal Community Development Workers (CDWs), who facilitated greater consultation with the communities as another form of collaborative learning. Two major reasons were advanced for the introduction of CDWs: they were regarded as a means of tapping into indigenous knowledge and also as instrumental in building the sustainability of interventions. Sustainability relates to the fact that CDWs, as volunteers and part of the community, could better ensure the ownership of development interventions even after a particular project had ended (Kontinen \& Melber 2015; Menike 1997). The fact that CDWs are also linked to experience and indigenous knowledge signalled more of a partnership between the EDF and the communities rather than a relationship of expert domination. This form of learning dynamic is consistent with the tenets of critical education.

Along with the introduction of CDWs, the EDF has also taken up a new approach of consulting community members on important issues before decisions are made, no longer taking the communities for granted. This is in stark contrast to the early years of the EDF when there was no consultation at all because members of the management assumed that they knew the communities' problems and how to solve them. By adopting a more participatory approach, the EDF seems to have not only appropriated critical education principles and practices but also survived the dilemma in which most NGOs find themselves, of trying to find perfect solutions without consulting with beneficiaries. This resonates with what Menike (1997) has to say:

NGOs, are based on [the] false assumption that we, the poor, do not know how to overcome our poverty and improve our conditions . . . For us, all this is quite hilarious ... The poor have their own pace and own rhythm of empowerment: a rhythm that is born out of wisdom and experience and not out of planning on a drawing board, sitting under a fan in a comfortable urban office.

(Menike 1997, 25)

The CDWs and the practice of consultation have together led to a more collaborative relationship between the EDF and the communities which has resulted in consultation during baseline surveys, proposal writing, implementation and evaluation. The realization that change can only happen from 
within and not from outside is another breakthrough in education and advances citizenship participation in development. There seems to be considerable consensus in the development literature that sustainable development cannot be externally driven. As Nyerere (1982) writes,

So development is for man, by man, and of man. The same is of education. Its purpose is the liberation of man from the restraints and limitations of ignorance and dependency ... This means that adult education has to be directed at helping men to develop themselves.

(Nyerere 1982, 37-38)

It should be stressed that community development as a discipline and profession has been associated with the two extremes of technical assistance and empowerment, with the empowerment and self-help models tending to align themselves with critical education, which, according to Freire (2004), promotes respect, power sharing and mutual exchange between the learner and the educator. The characteristics of education in the EDF, presented above, thus display a distinct critical education orientation. We therefore conclude with an analysis of facilitation methods of adult education in order to augment our claim that the EDF sponsors critical education. When one novice educator in the EDF was asked how she facilitates learning of community members, she remarked:

I always want learners [community members] to see me as one of them, so they do not fear me as a teacher but rather see me as one of them. We all appear as though we have come to learn, they ask me and I also ask them, but I don't try to appear as though I am a class apart . . . I was never taught that, it has been part of me, it has always been . . . maybe it is part of my principles.

(Naka)

Interestingly, Naka echoes Freire $(1972,71)$ when he says, "How can I dialogue if I regard myself as a case part from others - mere 'its' in whom I cannot recognise other 'I's?" Clearly, Naka rejects appearing before learners as superior either in knowledge or status. She also espouses dialogue, which is a major principle of critical pedagogy. This view is echoed by Keti who formerly trained as an agricultural assistant:

It depends on the class of the people where you've gone for that period of time; for example, if you are with farmers then you have to behave like farmers . . . I don't take myself to be a boss, that is out, then I can't behave like a primary or secondary teacher because these ones [farmers] are bosses with powers. 
Respect for learners - first for the knowledge they possess and then for their age - is key to critical education. Like Freire (2004), Keti also recognizes the inherent power of the learners. In short, the technist knowledge she possesses from school does not negate the fact that the learners also know certain things through experience. She further castigates facilitation methods used by primary and secondary teachers. This is what Freire (1972) rejected as "banking education", in which educators simply deposit information in learners who are perceived to be ignorant empty vessels. Finally, another novice educator with formal training in agriculture likewise notes:

Obviously the relationship between these adult learners and those students in school is not the same because here we share information ... in teaching you just come and give your information to the people you are teaching ... But here [EDF] we assume that these adults know something, and as an educator, you are just adding on what they know and getting out the superstition that they may have.

(Enid)

We may deduce from the words of the three novice educators quoted above that learning as a process of community development makes sense when it is a two-way process. The educator or community development worker assumes the role of a leader without diminishing the power of the learner or community member. This is contrary to the EDF's initial approach of changing the community in the direction of its desired goals using technist or professional strategies and simply providing resources as if they were a magic bullet.

We note that education programmes in the EDF were crafted according to views similar to conscientization and praxis (Freire 1972). The EDF has come to agree with the communities that it is not a shortage of resources that is responsible for poverty and ill health, but a failure to translate indigenous knowledge into a better life. This has led to new modes of engagement between the EDF and the communities with which it works based on the premise that any strategy to address the challenges of a community must take note of the local people's knowledge. This has been operationalized by enlisting CDWs who link the NGO with the recipient community.

The voices of the novice educators above describe an educational approach that has slowly become the norm in the EDF. In this we can observe the following key aspects of critical education: respect for learners (adults), dialogue as a method of facilitation, repudiation of the banking method, liberatory education, conscientization and praxis, an endeavour to flatten power relations and drawing from learners' experience. In summary, the above comments from staff and CDWs re-echo the principles of critical education advanced by Freire and Nyerere. In the next section we analyse the role played by the EDF's context in changing its community development philosophy to include education. 


\section{The role of context in shaping critical education in the EDF}

Many researchers concur that NGOs are in most cases defined by the context in which they operate (Ghosh 2009; Klees 2008). This applies to international as well as local or indigenous NGOs (Makoba 2018). The role of the contextual forces was also evident in the case of the EDF, both facilitating and hindering the crafting of its critical education programme. In what follows, we focus on what we consider to be the three key contextual elements in the work of the EDF - the beneficiary community, the government (local and central) and the donor community - and their implications for how critical education was conducted in practice.

Like many NGOs, the EDF at first tended to perceive its beneficiary communities as "poor" and in need of positive change facilitated by the NGO and taking the direction considered good by the latter. In practice, although people in Kibaale can be described as rural and vulnerable, they have a rich culture and their communities are strongly rooted in the Christian faith, aspects which have in essence been a source of pride. The communities have also previously benefited from empowerment programmes promoted by other NGOs and the government. There have, for example, been concerted campaigns for women's emancipation programmes, as a consequence of which the majority of CDWs and beneficiaries of the EDF are women.

When it became clear that rural people had vital ideas for the betterment of their lives, the EDF chose to partner with them rather than "helping" them as vulnerable individuals. This realization and resulting shift in the EDF's thinking later came to inform the concept of community development workers (CDWs) and respect for indigenous knowledge. When adult education was espoused as the major driver of community development, critical education became the best fit. It was also noted that respect for learners and dialogue, which are key to critical education, were born out of the desire to treat adult learners with respect, a feature emphasized by the local culture of the Banyoro. The EDF has also built an educational structure at the grassroots level, where CDWs carry out educational campaigns in health, agriculture and sanitation; however, because the CDWs are part of the community, the interactions are more dialogue than lecture, meaning that people learn from one another in a less threatening environment. This form of adult education has to all intents and purposes adopted the characteristics of critical education, to the credit of the EDF.

Despite recognition of the communities' capacities and the empowerment approach taken, some limitations on an ideal implementation of critical education has remained, principally related to inherent feelings of powerlessness on the part of rural people. The enduring power dynamics, including the traditional ways of defining powerful and powerless, have challenged the realization of the principles of critical education. Most community members still believe that EDF staff have knowledge that is superior to their own. This seems to be based on the educational, socioeconomic and urban status of 


\section{4}

Bananuka and John

EDF staff relative to the communities, in spite of the EDF's re-assuring them of their valuable knowledge and ability. Observations of training sessions showed that mostly community members preferred to be lectured to rather than engaging in dialogue and debate as equals. Although facilitators endeavoured to employ participatory techniques, there appeared to be some unwritten rules that elevated the views of educators above those of learners. Thus, change in the approach of an NGO encounters the existing pervasive power dynamics, which are hard to transform with a single NGO intervention.

The government is another key contextual factor in the EDF's critical education. Banks and Hulme $(2012,6)$ note that "NGOs are often polarised with local and national governments, but such a dichotomy overlooks the nature of relationships between the two, which can range from overt and hidden tensions and active hostility to cooperation and collaboration". As far as education and training is concerned, the EDF has had to align with the government for a number of reasons. First, local government involvement was required as endorsement for its community mobilization, with many stakeholders arguing that the EDF's profile was lifted thereby. The EDF also solicited the services and expertise of local government staff in the training of CDWs as, in the rural setting of Kibaale, it is rare to find specialized personnel in the areas of health, agriculture and water. This seeming fusion of the EDF and local government has had a profound impact on the training pedagogy. It was observed that trainers from the local government usually carried prepared presentations of "right knowledge" in a manner akin to banking education. Thus, the use of government employees in training, something required for its legitimacy and smooth operation, undermined the critical pedagogy approach preferred by the EDF. Government facilitators, referred to as resource persons, were more likely to employ teaching methods that were considered less participatory and critical, thus jeopardizing the overall aim of the NGO's approach.

The third and last contextual force is what we term the globalization effect. Despite being an indigenous, rural-based organization, the EDF still feels the impact of a globalized world, largely through the influence of donor funding from partners in the Global North which, as with most NGOs in the Global South, provide the EDF with almost all its funding. However, financial assistance from the Global North comes with some conditionalities which are rooted in the ideologies of source-donor country or international policies and declarations. For example, North-South financial support tends to follow international development priorities based on agendas such as MDGs and SDGs. This means that global debates and decisions directly impact on the flow of resources from the Global North which ultimately affects the work of the EDF. Today, however, most development partners support facilitation strategies that are learner-centred or inclined towards the tenets of critical education. For instance, Kane (2008) notes that although the World Bank, like most development agencies, had for long espoused a technist approach to 
rural transformation, it has recently jumped on the bandwagon of participatory approaches, which renders it supportive of critical education. Thus, EDF aspirations for critical education have found favour with most funders.

However, different donors have different conditions governing what an NGO they support can or cannot do (Barr et al. 2005; Contu \& Girei 2013; Kontinen 2003; Kontinen \& Melber 2015; Shivji 2004). When it comes to critical education, the impact of the donor community on the EDF is doubleedged. While donors have been supportive of critical education, some of their conditions conflict with the principles of the EDF and the culture of the local community. As the saying goes, "he who pays the piper calls the tune". For instance, the funded projects have timelines meaning that the EDF has limited options when it comes to implementation, leaving little space for the EDF to fulfil their dreams for the people of Kibaale, as they have to strike a balance between the interests of the donors and the communities. The EDF thus finds itself at the centre of these competing forces and has to manage a delicate balancing act.

\section{Conclusion}

The case of the EDF discussed in this chapter has helped to illuminate the emergence, growth and practice of critical education in community development shaped by contextual forces. Critical education, which became popular due to its espousal of democratic principles of learning, has often been transplanted into educational programmes as if it were a magic bullet, sometimes with little success. The emergent lesson, therefore, does not come in the shape of a model to be replicated by other NGOs or CSOs but, rather, stresses the importance of context in community development interventions. This particular case showed how an NGO shifted its community development approach from social enterprise to education-led integrated development as it learned from the environment in which it was located.

At a more general level, the chapter's narrative demonstrated the intricacies of running an NGO, particularly in the Global South. NGOs should maintain a delicate balance between the needs of the beneficiary community, the legal regime and the values of the funding agencies. Organizational survival is greatly dependent on flexibility in the face of contextual forces and the accommodation of shifting interests. The EDF's shifting of organizational goals, which led to a pedagogical philosophy tending towards critical education, provides an example of such flexibility, and is a product of the EDF's continual assessment of its context and how best to serve the community.

\section{Notes}

1 Poverty is relative and has no universal meaning. In this case, it is used to refer to individuals and households lacking basic necessities of life such as decent housing, access to land and sufficient access to basic medical care. 


\section{Bananuka and John}

2 The British colonial masters had gifted this part of the Bunyoro kingdom to the Buganda kingdom for its support during annexation of the resistant King Kabalega of Bunyoro. To date, Buganda still have titles for the land occupied by Banyoro.

3 CDWs are paralegal professionals based in communities who normally possess special skills vital to community needs. CSOs often, and the government sometimes, solicit for the support and services of CDWs as entry points to communities. Not only do they understand community dynamics, they also understand the language of the community.

4 A community development approach that emphasizes socio-economic transformation driven by experts, that is experts prescribing the "right approach" to a community's development challenges

\section{References}

Asiimwe, W. \& Nolan, P. (2001). Land reform and sustainable livelihoods in Kibaale District. Kampala: Ireland Aid and APSO.

Babikwa, D. (2004). The political economy of adult education in Uganda. In A. Okech (Ed.). Adult education in Uganda: Growth, development, prospects and challenges (pp. 35-50). Kampala: Fountain Publishers.

Bananuka, T.H. (2014). Adult education for community development: the case of a Ugandan non-governmental organisation (Unpublished Doctoral Thesis). University of KwaZulu-Natal, Pietermaritzburg, South Africa.

Bananuka, T. \& John, V.M. (2015). Picturing community development work in Uganda: fostering dialogue through photovoice. Community Development Journal, 50(2), 196-212.

Banks, N. \& Hulme, D. (2012). The role of NGOs and civil society in development and poverty reduction (BWPI Working Paper 171). Manchester: The Brooks World Poverty Institute, University of Manchester.

Barr, A., Fafchamps, M. \& Owens, T. (2005). The governance of non-governmental organizations in Uganda. World Development, 33(4), 657-679.

Beder, H. (1989). Purposes and philosophies of adult education. In S.B. Merriam \& P. M. Cunningham (Eds.). Handbook of adult and continuing education (pp. 37-50). San Francisco, CA: Jossey-Bass.

Brookfield, S. (1984). The contribution of Eduard Lindeman to the development of theory and philosophy in adult education. Adult Education Quarterly, 34(4), 185-196.

Busingye, J.D. (2011). Reducing risk: Local knowledge for livelihoods security among Ugandan small holder crop farmers. Pietermaritzburg: University of KwaZulu-Natal.

Chilisa, B. \& Preece, J. (2005). Research methods for adult educators in Africa. Hamburg: UNESCO Institute for Education.

Contu, A. \& Girei, E. (2013). NGOs management and the value of 'partnerships' for equality in international development: What's in a name? Human Relations, 67(2), 205-232.

Farrow, R. (2017). Open education and critical pedagogy. Learning, Media and Technology, 42(2), 130-146.

Foley, G. (2001). Radical adult education and learning. International Journal of Lifelong Learning Education, 20(1), 71-88.

Freire, P. (1972). Pedagogy of the oppressed. London: Penguin Books.

Freire, P. (2004). Pedagogy of hope: Reliving pedagogy of the oppressed. London: Continnum. 
Ghosh, S. (2009). NGOs as political institutions. Journal of Asian and African Studies, 44(5), 475-495.

Holst, J.D. (1999). The affinities of Lenin and Gramsci: implications for radical adult education theory and practice. International Journal of Lifelong Learning Education, 18(5), 407-421.

Holst, J.D. (2009). Conceptualizing training in the radical adult education tradition. Adult Education Quarterly, 59(4), 318-334.

Kane, L. (2008). The World Bank, community development and education for social justice. Community Development Journal, 43(2), 194-209.

Klees, S.J. (2008). NGOs, civil society, and development: Is there a third way? Current Issues in Comparative Education, 10(1/2), 22-25.

Kontinen, T. (2003). Partnership and trusteeship in management of development cooperation projects: Case of Finnish NGO development co-operation in Tanzania. In T. Kontinen \& M. Seppanen (Eds.). DEVELOPMENT - Concepts, policies and practices (pp. 131-159). Helsinki: Finnish Society for Development Studies.

Kontinen, T. \& Melber, H. (2015). Civil society, cooperation and development. Journal für Entwicklungspolitik, 31(1), 4-12.

Kuhanen, J. (2000). Poverty and wealth in traditional African societies: Considerations regarding wealth, well-being, and nutrition in the Ganda and Nyoro societies, c 1800 to 1875. Nordic Journal of African Studies, 9(1), 70-95.

Lovett, T. (1972). Adult education and community development: A network approach. Liverpool: ERIC ED 074320.

Major, T. \& Mulvihilland, T.M. (2009). Julius Nyerere (1922-1999), an African philosopher, re-envisions teacher education to escape colonialism. Journal of Marxism and Interdisciplinary Inquiry, 3(1), 15-22.

Makoba, J.W. (2002). Nongovernmental organizations (NGOS) and Third World development: An alternative approach to development. Journal of Third World Studies, 1-10.

Makoba, J.W. (2018). Non-governmental organizations and the African state. In G.K. Kieh. (Ed.). Contemporary issues in African society: Historical analysis and perspectives (1st ed., pp. 29-46). Austin, TX: Palgrave Macmillan.

Menike, K. (1997). People's empowerment from the people's perspective. In D. Eade (Ed.). Development and Patronage (pp. 25-30). Oxford: Oxfam Print Unit.

Muhumuza, W. (2005). Unfulfilled promises? NGOs' micro-credit programmes and poverty reduction in Uganda. Journal of Contemporary African Studies, 23(3), 391-416.

Niederfrank, E.J. \& Cole, L.W. (1972). Education for community development. Review of Educational Research, 29(3), 304-307.

Nyerere, J. (1973). Freedom and development/Uhuru Na Maendeleo: A selection from writings and speeches of 1968-1973. Oxford: Oxford University Press.

Nyerere, J. (1982). Adult education and development. Adult education and development, 19(Special Issue), 37-45.

Rugadya, M. (2009). Escalating land conflicts in Uganda: A review of evidence from recent studies and surveys. Kampala: International Republican Institute (IRI) and Uganda Round Table Foundation.

Rulekere, G. (2006). 24 arrested over Kibaale tribal conflict that has claimed 3: More tribal conflict. Retrieved from www.ugpulse.com

Sanders, B., Phillips, J. \& Vanreusel, B. (2012). Opportunities and challenges facing NGOs using sport as a vehicle for development in post-apartheid South Africa. Sport, Education and Society, 19(6), 789-805. 


\section{Bananuka and John}

Shivji, I.G. (2004). Reflections on NGOs on Tanzania: What we are, what we are not, and we ought to be. Journal of Development in Practice, 14(5), 689-695.

Spence, R. \& Wolff, M. (1953). Adult education and community development. JSTOR: Review of Educational Research, 23(3), 248-260.

Van-Der-Veen, R. \& Preece, J. (2005). Poverty reduction and adult education: beyond basic education. International Journal of Lifelong Education, 24(5), 381-391.

Youngman, F. (2000). The political economy of adult education \& development. London: Zed Books.

Zapf, W. (2004). Modernization theory - and the non-western world. Paper presented at the Conference on Comparing Processes of Modernization, University of Potsdam, Wissenschaftszentrum, Berlin. 


\title{
14 Social accountability monitoring as an approach to promoting active citizenship in Tanzania
}

\author{
Ajali M. Nguyahambi and Haji H. Chang'a
}

\section{Introduction}

This chapter scrutinizes attempts to promote change in current citizenship habits through different forms of participation. It focuses on social accountability monitoring (SAM), which is one of the intervention approaches globally used to facilitate changes in citizenship practices, especially in regard to citizen-state relations. The approach is widely employed by many civil society organizations (CSOs) to promote people's active participation in order to influence the outcomes of governance processes (UNDP 2013; Ahmad 2008). SAM draws its legitimacy - among actors focusing on democratic governance and development - from its ability to create new spaces for citizens and civic groups in which to interact with the government and its agencies; it thereby recognizes citizen participation as a necessary and important practice (FriisHansen \& Ravnkilde 2013), especially in contexts where the government is traditionally the dominant actor in governance. Previous research has shown that there are multiple factors affecting the outcomes and implementation of SAM. Context-based factors include the role of different kinds of political institutions, the types and capacity of CSOs involved and the nature of statesociety relations and those between groups and citizens (Hickey \& King 2016; King 2015; Campbell et al. 2010; Shankar 2010). In addition, interventionbased factors such as the credibility of lead actors - that is, individuals and organizations (Joshi \& Houtzager 2012) - also have impact on results.

In this chapter, we analyse the ways in which the implementation of SAM both promotes and hinders the ideal model of active citizen participation in Tanzania. We begin with general discussion based on the literature, followed by illustrative examples from the context of a CSO initiative located in Kondoa District whose goal is to improve service delivery in the health sector. In the course of this, we address the following questions: (a) What kind of model is SAM, both in general terms and from the perspective of the particular CSO implementing it? (b) What kinds of changes does SAM promote with regard to citizen-state relations at the local level? (c) What kinds of discrepancies can occur between ideal SAM-models and their implementation in Tanzania? 
In what follows we first review the principles of the SAM approach, then discuss the model used and outcomes and discrepancies with the model in the course of its implementation. In conclusion, we argue that the success of the SAM model in promoting changes in the direction of a certain kind of active citizenship depends on whether the promotion of the ideal model takes into account contexts at the local level.

\section{Social accountability monitoring and active citizenship}

In this section, we describe the SAM approach and the kind of active citizenship it promotes, briefly sketching the approach's historical background in international development in general, and in Africa in particular. We then analyse accountability as the central issue in the SAM model, as well as experiences of promoting "active citizenship" through SAM as an established governance framework.

The adoption of the SAM approach in sub-Saharan Africa commenced in the mid-1980s as a corrective mechanism for failures in public service delivery systems. Indeed, early initiatives came along with the adoption of World Bank (WB) and International Monetary Fund (IMF)-led Structural Adjustment Policies (SAPs) that promised to fix trade and production environments in order to boost declining economies and public service delivery (Malena \& McNeil 2010). In the same vein, governance was equally subject to reform that promoted approaches facilitating citizen-led forms of accountability. Therefore, SAM has been adopted in order to provide a mechanism that stimulates improvement in service delivery (Friis-Hansen \& Ravnkilde 2013) and addresses socio-economic inequalities, especially poverty (Ringold et al. 2012). With the SAM approach, citizens and civic organizations undertake a wide range of actions in order to hold the state to account; this gives citizens the opportunity to contribute to improving the results of governance and to influence the quality of service delivery (Claasen \& Alpin-Lardies 2010).

Generally, social accountability monitoring as an approach seeks to promote a particular view of active citizenship, one cornerstone of which is a participating citizen. Participation involves the shift in status of ordinary people from mere beneficiary to citizen, from consultation to decision-making and from appraisal to implementation. In promoting the right to participation in social, economic, cultural and political life, SAM is embedded in and draws from the nexus of basic human rights (Gaventa 2004). The approach emphasizes citizens' rights to be active and involved in making and implementing decisions that affect them, and, thus, also regards participation as a duty towards the government and fellow citizens. According to Gaventa and Valderrama (1999), participation is both the right and duty of a citizen in situations where local governance calls for the increased participation of civil society in activities that traditionally form part of the public sphere. This implies that participation is a key element in governance at all levels. It facilitates the introduction of improvements to public services, makes local 
government more accountable and, more importantly, deepens democracy by complementing representative forms with more participatory forms (Gaventa 2002); as Lister (1998) observes, participation is an expression of human agency in the political arena. In line with this, SAM's underlying idea is that the influence of, and exercise of control by, citizens on governance happens not only through indirect or representational forms of participation, but also through direct participation. Therefore, the idea of participation as a civic right emerges from the discourse of governance and citizenship that seeks to address the exclusion of citizens from policy formulation and decision making, especially in key areas that affect their lives.

Moreover, SAM's view of active citizenship expects informed citizenry, as information catalyzes citizens' action. This idea guides the philosophy behind SAM initiatives in sub-Saharan Africa. For example, those in Tanzania focus on motivating citizens to "be informed, involved, and monitor every move, in order to make their government work for them" (Mugizi 2013; Colm 2008). In this respect, people are expected to speak their minds and be proactive in demanding accountability, as citizens' actions are supposed to trigger state responses. So, SAM initiatives emphasize the realization of basic political and civic rights, access to information, as well as government responsiveness vis-ávis citizens' demands.

Additionally, SAM builds on the accountability resulting from active citizen participation as a cornerstone of good governance. Accountability, in this context, plays two main functions: first, it prevents, or rather limits, the abuse of power and ensures the predictability of the actions of the state and its agencies; second, it provides continuous public supervision and control of the state and its agencies in order to ensure that public services are suited to citizens' needs and interests (Joshi 2013; Green 2015; Malena \& McNeil 2010). SAM emphasizes the importance of citizens' participation (direct or indirect), which enables them to demand accountability from policy makers, service providers and program managers, and to ensure that public/state institutions act in their best interests. It also denotes the "rights-duty" relationship between state institutions as duty bearers and citizens as rights holders (Clippinger et al. 2014; UNDP 2010), thereby aligning citizenship with the rights-based approach to development in which duties are well executed and rights are realized.

Accountability framework literature conventionally identifies vertical and horizontal forms of accountability (Joshi 2013; 2008; Ahmad 2008). Vertical accountability takes place between state and citizens, wherein the main instruments that citizens use to hold duty bearers accountable are periodic elections, usually considered democratic practices. Horizontal accountability takes place between different state agencies via a separation of powers. A form of political accountability, it is exercised through checks and balances applied to state institutions that involve parliamentary oversight, independent judiciary and ombudsmen offices, such as anti-corruption bureaus, human rights commissions, Comptroller and Auditor Generals and public service 


\section{Nguyahambi and Chang'a}

codes of ethics. Nevertheless, in order to ensure the optimal reinforcement of existing accountability mechanisms, governance actors encourage citizen-led accountability initiatives that go beyond periodic elections. In this regard, SAM initiatives respond to the situation that vertical and horizontal accountabilities are never self-sufficient and exhaustive enough to make public officials fully inform citizens regarding the happenings taking place in the public service arena, especially at the grassroots level (World Bank 2007; Hyden et al. 2003).

It is not the intention of SAM to replace existing accountability mechanisms; instead, it is meant to reinforce and complement them by emphasizing the direct or indirect participation of ordinary citizens and civic groups in demanding accountability from the duty bearers. SAM initiatives can be initiated and/or supported by the state, civil society and/ or citizens, although very often they are demand-driven and operate from the bottom up (Clippinger et al. 2014; Malena \& Chhim 2009). Although widely employed, the environments in which SAM initiatives are implemented differ from context to context, involving a range of implementation mechanisms and actors at various levels and across the sectors (UNDP 2013; Claasen \& Alpin-Lardies 2010). In Africa and elsewhere in Asia and Latin America, SAM has been implemented in various ways in the course of building accountability that relies on citizens' engagement. Examples of these approaches include information campaigns (i.e., Citizen Charters and Citizens Service Centres) and budget transparency (i.e., public reporting of revenues and expenditures, budget literacy campaigns, public expenditure tracking and independent budget analysis), as well as social accountability checks (i.e., community score cards, social audits, citizen report cards, citizen satisfaction surveys, grievance redress and citizens' juries). The approaches also include different forms of consultation, such as public hearings, focus group discussions and advisory committees, participatory planning, community management, community contracting and citizen membership in decision-making bodies (Friis-Hansen \& Ravnkilde 2013; Mattes 2010; World Bank 2005; 2003).

Generally, SAM initiatives aim to strengthen the voices of citizens when demanding greater accountability and responsiveness directly from public officials and service providers. They emphasize the importance of the moral responsibility of public officials, politicians and service providers to be transparent and responsive to the needs of the people in terms of how they exercise authority, on the basis of the relationship between right holders and duty bearers (Friis-Hansen \& Ravnkilde 2013; Khadka \& Bhattarai 2012). However, the environment in which implementation of SAM initiatives takes place creates a number of limitations that inhibit both reinforcing and complementing existing accountability mechanisms. In Tanzania, for example, the SAM implementation environment is characterized by the constrained interface between CSOs (facilitators of SAM initiatives) and state institutions because the public accountability culture and its systems are relatively weak 
compared to the strong executive arm of the government (Green 2012; APRM 2011; Lawson \& Rakner 2005). Because of the state dominance of service delivery and governance processes, the goal of meeting the objectives of SAM initiatives while at the same time overcoming state fears of citizen involvement remains a challenge. This has implications for how CSOs, as facilitators of such initiatives, can effectively manage activities to encourage and support citizens' active participation. Therefore, the benefits of the SAM approach are not automatically realized; rather, successful implementation in this regard depends on grassroots realities when encouraging citizens to exploit opportunities to shift towards active citizenship and overcome challenges that may inhibit the move.

\section{Implementation of social accountability monitoring}

In this section, we discuss experiences of implementing SAM initiatives in Tanzania, where the model is employed by a large number of CSOs. We provide illustrative examples from an organization called Sikika, ${ }^{1}$ a nation-wide NGO that implements SAM in the area of health services provision, and one among the Tanzanian CSOs that have been at the forefront of ensuring that local communities in Tanzania are empowered enough to engage in all the essential matters that determine their wellbeing. Sikika's special interest lies in promoting the active engagement of citizens with health service providers and policy makers in order to realize good governance and the accountability of public resources, especially at the lowest levels of governance (local government authorities) and service delivery (health centres) (Sikika 2015). Sikika has also implemented a SAM initiative in Kondoa District, from where we have drawn the research material informing our reflections. This includes oneto-one interviews with thirty community members from three selected villages in Kondoa District, as well as two programme officers from Sikika. In addition, we interrogated interview materials with secondary data extracted from SAM program implementation reports and observation of actual village environments, especially in the respective health service centres. In what follows, we first describe how the SAM model is perceived and implemented in the context of Tanzania in general, and from CSO and Sikika perspectives in particular. We then discuss the outcomes of SAM initiatives, once again, firstly in general and then in the particular context of Kondoa, finally pinpointing discrepancies between ideal principles and the actual implementation of SAM.

\section{Social accountability monitoring: the $N G O$ perspective}

In Tanzania, NGOs consider the SAM approach a mechanism that creates an alternative civic space for citizens' participation in governance and servicedelivery processes, especially at lower levels of governance. Therefore, through implementation of SAM initiatives, NGOs tend to create a novel space for 


\section{Nguyahambi and Chang'a}

citizens' engagement that differs both from the existing everyday life in the communities and from state-organized spaces. In occupying the alternative civic space, NGOs emphasize two major elements in the promotion of active citizenship: citizens' voices in decision making and citizens' access to information.

Citizens' voices in decision making are of paramount importance, especially when reflecting on the scale of the particular decision and its implication. Where decisions concern the urgent need to improve basic service delivery in a particular community, citizens need to take part in decisionmaking processes in order to influence or contribute to their outcomes. In Tanzania, the lack or insufficiency of citizens' ability to influence these processes is one of the key challenges facing marginalized community members. The challenge is especially observable in rural communities at the lowest possible levels of governance. In a context where public actors dominate community life and civic activities, the prevailing question is the extent to which citizens' voice can be integrated into decision-making processes, ultimately facilitating community members' making a difference.

Through SAM initiatives, CSOs promote citizens' voices in decision making in service delivery processes, as exemplified by Sikika's interventions, which mobilize communities at the village level. Sikika implements SAM by enabling local communities to monitor plans, budgets and implementation of health service delivery through a SAM team formed by representatives from the community. The purpose of this particular activity is to ensure that the decisions and actions of local government authorities' officials and health service workers take into account community concerns. Although the institutional environment for implementation of SAM initiatives lacks an elaborate legal base and a clear shared understanding of their status among local governance actors, Sikika's initiatives have helped to highlight the importance of citizens' voices in expressing community demands, as noted by one SAM team member, a representative of a rural community:

For a long time now, we have experienced poor services being provided by health centres and dispensaries in our communities, but it was not easy for community members to change the situation. Now, by means of participating in a SAM team, at least we have reminded health service workers and district officials about key challenges which people wish to be addressed.

In Tanzania, access to information is a right guaranteed in the constitution and legislatively protected by the Access to Information Act of 2016. This is important in order to afford citizens the opportunity to participate democratically in community life. Promoting access to information has the goal of cultivating citizen acceptance and support of democratic principles such as participation, accountability and transparency. In this respect, the SAM approach provides an opportunity to create a common space wherein 
individual citizens may be seen and heard, and reveal themselves through arguments, discourse and action, with citizens being considered users, producers and conductors of information. In its implementation of SAM, Sikika conducted an awareness campaign in local communities about the right of access to information, its importance and ways of gaining access to it. The purpose of the awareness campaign was to cultivate a more informed populace in order to facilitate meaningful state-citizen interactions. For example, representatives of local communities formed a SAM team to conduct accountability monitoring in health services that enabled them to ascertain the evidence-based status of the service in selected health centres. This enabled local communities to dialogue with health service workers and district officials to demand accountability on identified issues including alleged misuse of money and power.

Accountability monitoring activities helped to improve information supply channels. For example, one district authority clarified an identified mismatch between budget figures and the actual status of services in health centres. Villagers learned that discrepancies between budget estimates and actual expenditure often occur because they depend on disbursements from central government. Similarly, the district authority took corrective measures on practical concerns raised by the SAM team, for example, they started immediate renovation of incinerator in one of the health centres for which funds had been allocated, although somehow implementation had been delayed.

\section{Outcomes of citizens' engagement: Results from SAM initiatives}

The outcomes of the SAM approach in Tanzania are expected to manifest in the form of a change in citizens' habits and practices in their interaction with government officials and/or service providers, a response to the exercise of citizenship rights among community members on the one hand, and effective execution of duties among service providers on the other. It is the right of citizens to access information regarding service delivery processes, and use such information to act; at the same time, it is the duty of service providers to share such information freely and take necessary measures to comply with citizens' demands. Such new habits and practices either constitute corrective measures for governance and service delivery challenges or reinforce already existing accountability mechanisms. As elucidated by Claasen and AlpinLardies (2010), SAM as an approach to promoting active citizenship aims to empower ordinary citizens in the exercise of their inherent right to hold governments accountable for how they exercise authority. Likewise, an attempt to promote citizens' engagement focuses on influencing the ways in which citizens play their role in interactions with government officials, that is, decisionmakers and service providers (Green 2015; Malena \& McNeil 2010). Thus, SAM initiatives across the country and in a range of sectors have focused on promoting three main elements: community interest and participation in 


\section{Nguyahambi and Chang'a}

service delivery activities, community willingness and confidence to voice accountability issues and adherence to formal administrative procedures at service centres.

The CSOs' quest to cultivate community interests and members' participation in service delivery activities has the goal of offering greater control over the actions of service providers by the underprivileged. Community control of service delivery processes is expected to influence the outcomes of service delivery by ensuring that community demands are taken into consideration. The essence of citizens' engagement in service delivery activities is to ensure inclusive processes (UNDP 2013; Gaventa \& McGee 2013) in which communities are viewed as key stakeholders (Malena \& Chhim 2009). In this respect, by implementing SAM initiatives, CSOs have aimed to awaken a community spirit of participation in order to exploit individual and collective intelligence in influencing decision-making processes and service-delivery outcomes in different sectors and communities.

CSOs mobilize local communities to attend village meetings that deliberate on different issues of common concern and the implementation of collective decisions. For example, in Sikika's intervention, communities in selected villages participated in village meetings that deliberated on issues of cleanliness and the lack of pit latrines at their health centres. Furthermore, the communities went on to implement those decisions by contributing their manual work in constructing pit latrines and cleaning the health centre's surroundings. Thus, SAM served as a mechanism that provided space for citizens' participation in decision-making and service-delivery activities that collectively addressed the identified service challenges. At the same time, community participation in monitoring the physical status of health service provision ensured that service providers executed their duties effectively and made economic use of allocated funds according to the demands of local communities and budget provision.

Development of community willingness and confidence are additional outcomes that CSOs expect to achieve from SAM initiatives. Community willingness is about the desire to take collective action to ensure the accountability of service providers, while community confidence relates to the conviction of community members that they possess the power (rights) which, if exercised, can influence or change an existing situation through collective action. Thus, willingness and confidence are considered important attributes in effective citizen participation in social, economic and political life (individually or collectively). Similarly, Friis-Hansen and Ravnkilde (2013), and Gaventa and Barrett (2010), suggest that community willingness and confidence cultivate a sense of altruism on issues of community interest, such as the need to address challenges facing public service delivery, without which it would be hardly possible to promote change in citizenship habits.

The mechanism employed by CSOs to cultivate community willingness and confidence involved a sensitization campaign in local communities in order to develop enthusiasm and motivate them to voice pressing accountability 
concerns in their everyday encounters. For instance, Sikika mobilized local communities - beneficiaries of health services - to take necessary action based on information (evidence of shortfalls) collected during health service monitoring activities in their villages. Consequently, people started to report service irregularities to the responsible authorities and request information and clarification from health service workers. Some of the raised issues, such as the limited availability of basic medicines, received immediate attention in the shape of increased budget allocation by the district authority. Similarly, community demand was raised on other issues that required long-term solution to be solved such as shortage of health workers in respective health centres. All of these constituted important achievements for the SAM approach.

An additional expected outcome that CSOs aim to achieve by implementing SAM initiatives is the adherence of district officials and service providers to formal administrative procedures. The latter are important attributes of state-citizen interaction because they establish a system of rules that aims to ensure the accountability of office-holding individuals. Therefore, CSOs' advocacy of "active citizenship" in the context of the SAM approach focuses on ensuring that local communities at lower levels of governance take an active role in state-citizen interaction to reinforce adherence to existing local governance systems. SAM thus facilitates the effective use of existing administrative procedures in order to limit the abuse of power and ensure the predictability of service providers in their interactions with communities. In relation to service delivery, limiting the abuse of power and ensuring predictability results in meaningful and continued interaction between service providers and communities in the context of "duty bearer-right holder" relationships (Clippinger et al. 2014; Ringold et al. 2012).

In order to ensure adherence to existing governance systems, CSOs mobilized communities to demand information about service delivery in their health centres. This prompted service providers to respond to community demands, providing the required information in accordance with established procedures; in other words, SAM promoted the use of existing systems through which service providers should provide information to the public. For example, Sikika mobilized villagers to demand health service information from health centre workers in the form of reports of medical supplies, budget allocations and the key decisions made by health centre committees. Although the use of public notice boards seemed to be somehow ignored by health workers, it is still among the existing mechanisms for ensuring transparency and making service providers to account for their decisions and actions. Indeed, it makes it possible for interested individuals to have easy access to information about health plans, budgets, financial and implementation reports, available medicines and other key decisions made by health centre committees. Due to ever-increasing demand from villagers, health service workers started to post information deemed important on public notice boards for wider access by the villagers. Indeed, the use of public notice boards at health centres helped to reduce unnecessary confrontations between 


\section{Nguyahambi and Chang'a}

health service workers and communities, at the same time encouraging communities to follow health-related information at their respective health centres continuously.

\section{Tensions in the implementation of SAM: Ideal versus reality}

In this section, we point out some typical discrepancies when it comes to putting ideal SAM models into practice. The extent to which anticipated SAM outcomes can effectively be achieved depends on the dynamics involved during its implementation in a particular context. Ideally, the process of implementing a SAM approach requires the kind of methodologies that can ensure not only the instrumental objective of improving service delivery (Friis-Hansen \& Ravnkilde 2013; Joshi 2008), but that also deepen grassroots democracy by making citizen-state interaction at lower levels of governance more transparent and open to civic involvement (Malena \& Chhim 2009; Gaventa 2004; 2002). Many CSOs in Tanzania implement SAM initiatives in order to mobilize communities to re-define citizen-state relationships and promote wider citizen participation in community life, as well as building accountability that relies on citizen engagement in decision-making and service-delivery processes. However, there are challenges to balancing the "ideal process" of SAM against "realities on the ground". In what follows, we discuss five examples where ideals and practices can collide, examining the ideals of making SAM a community-led process that ensures the wide participation of community members, enhances citizen-service provider dialogue, and promotes access to information and the legitimacy of CSOs facilitating SAM initiatives.

First, there is a tension between the SAM model's ideal of citizens' engagement initiatives being community driven, and the practice of significant CSO facilitation. Historically, citizen engagement in governance and development processes in Tanzania has had a narrow field, and open interaction between citizens and government officials/service providers has been limited (Lawson \& Rakner 2005; Lange et al. 2000). The SAM approach, and related initiatives implemented by many CSOs, aims to mobilize communities to engage in redefining citizen-state relationships as a way of opening up the space for citizen participation. Experiences of such initiatives show that facilitators of the approach have managed to promote the participation of communities in decision-making processes in the framework of interaction between rights-holders and duty bearers, especially those related to service delivery. For example, Sikika assisted local communities in collecting evidence of poor prioritization in budget allocations on the part of the district authority with regard to infrastructure development in their health centres. As a result of the activities of the SAM team, the district authority responded to community observations regarding allocations which it had previously ignored on the grounds of "limited budget". Subsequently, the district authority incorporated the idea of constructing mortuary buildings in health 
centres into its comprehensive district health plans, and disbursed some funds to facilitate the renovation of other worn-out buildings. Thus, the CSO managed to cultivate understanding among community members of the importance of citizen engagement in service-delivery processes.

Ideally, citizen participation ought to be the goal of all community members, one driven by the impetus provided by individual consciousness and the community. However, in this case participation was by invitation of the facilitating CSO rather than initiated within the communities. Brock, McGee and Gaventa (2004) observe that one of the major challenges of invited participation is the risk of limiting consideration of the best interests of citizens. The facilitators, such as CSOs, tend to know more than citizens and, thus, take control of proceedings. Sikika conducted open public meetings with villagers to introduce a SAM program focusing on health service delivery, even though the communities had not previously established that health services required such interventions. In practice, the actual implementation of service-monitoring activities was controlled by the facilitating CSO, rather than being community driven. Consequently, communities lacked ownership of the SAM process, which, in the end, compromised the essence of citizen engagement and the need to promote active citizenship.

Second, while SAM ideally encourages broad community participation, the scope of participation can be effected by the representation approach used by CSOs during implementation. The essence of promoting broader citizen participation in community life emanates from the need to create a more democratic society. Indeed, meaningful governance at the local level cannot be imagined without the effective participation of the largest possible number of local community members (Mugizi 2013; Green 2015). In a context where power and civic responsibility have been somewhat dominated by the state, citizen engagement initiatives aim to open up space for more inclusive governance processes that allow the direct exercise of citizenship rights and duties at grassroots levels. In Tanzania, CSOs have implemented SAM initiatives with the purpose of facilitating the participation of the people in deciding on matters affecting their lives, planning and executing their development programs and fostering partnerships between civic groups at lower levels of governance. For example, Sikika's SAM initiatives demonstrated that citizen participation has influenced decision-making processes and the quality of health-service delivery. Subsequently, communities acknowledged that they were enjoying relatively improved service delivery in the form of increased availability and accessibility of medicines, medical reagents and other medical supplies in their health centres.

However, although SAM aimed to promote greater citizen participation at the local level, in many cases the level of participation may be limited to just a small number of community members. For instance, Sikika opted to work with a few representatives selected at public village meetings. As one villager recalled, 
I remember I participated in the SAM meeting. One day Sikika people came to our village and conducted an open meeting with village community members. They first explained the purpose of coming and then introduced the SAM project. It was at that meeting where we selected one person who went to Kondoa town to represent our village in the SAM project.

During actual implementation, 15 members representing different categories of health service stakeholders - including ordinary villagers, ward councillors, health workers, religious leaders, the district management team and district health board, ward executive officers, CSOs and health centre boards formed the district SAM team. Out of 15, only five members represented local communities (ordinary villagers) in the SAM district-based team that carried out the actual monitoring activities in the selected health centres. Thus, the anticipated wider community participation was limited to voting for SAM team representatives, which was exercised during open meetings at which Sikika introduced the SAM program in the various villages. In this respect, the expected benefits of the ideal of wider citizen participation collided with practices of participation through representation by a few selected individuals.

Third, social accountability interventions aim to promote meaningful dialogue between citizens and service providers. This ideal often clashes with the unwillingness of the service providers to undertake such dialogue. Through the application of SAM models, CSOs envision a stronger citizen voice directly demanding greater accountability and responsiveness of public officials and service providers. Citizens are expected to interact freely with service providers in order to communicate what needs to be shared. In so doing, CSOs strive to make citizen engagement sufficiently user-friendly to attract the interest of ordinary community members and win their confidence. Participation mechanisms and means of communication are ideally facilitative in order to encourage community members to fit into engagement processes. Developing such an environment is necessary in Tanzania because historically the space for citizens' engagement, especially at lower levels of governance, has not been open or broad. However, during the implementation of SAM, interaction between community members and service providers, in some instances, can be characterized by the overreaction of both parties to each other. For example, Sikika documented that, during verification visits, SAM team members encountered resistance and limited cooperation from health workers in some health centres in the form of reluctance to provide the required information (Sikika 2013; 2016).

Rather than offering an accountability tool, service providers sometimes considered SAM activities to be police work intended to uncover wrongdoings. Health workers perceived citizens as being too demanding and asking things that, before the SAM intervention, were taken for granted by both stakeholders. Villagers had previously accepted being told that some 
medicines were not available in their service centres even when no official information was posted on the public notice board. On the other hand, citizens considered service providers uncooperative due to their reluctance to respond to demands or clarify answers to the questions posed to them, hence fuelling tensions. Thus, CSOs' efforts to promote active citizenship was constrained by the lack of desire for mutual learning between service providers and local communities. Generally, service providers misinterpreted initial WB and IMF drives to have the SAM model adopted across Africa and other developing countries as a corrective mechanism for failures in public service delivery systems (Malena \& McNeil 2010).

Fourth, while SAM interventions aim to promote citizen access to information, its implementation can be checked by the inability of local communities to understand the information accessed, something required in order to make appropriate use of information gained from their active participation, as opposed to that available as "listeners" or passive participants. In light of this, CSOs work to promote civic awareness in communities to cultivate a better understanding of pressing issues regarding accountability and transparency in service delivery processes. For example, Sikika's accountability monitoring cycle ensured that local communities got access to, and stayed well informed on, health service plans, budgets and implementation reports, including both physical and fiscal status. In practice, however, it was rather difficult for SAM team members from local communities to understand the content of documents such as district plans, budgets and implementation reports, largely due to the use therein of rather technical English. SAM team members relied on analysis of the reports after translation and digestion by CSO facilitators. This might have affected their confidence in the course of interacting with service workers/district officials. As one community member reported:

When we started doing analysis of district plans and implementation reports, it was a challenging task to me. This is because most of documents were written in a foreign language [English], which made it difficult for me to understand the content. However, I am very thankful to our facilitators who helped to interpret and put it in an understandable language [Swahili].

When there is a low level of education among local community members, it is potentially possible to get them to accept information in the form it has been explained to them by facilitators, even where there may be two or more different interpretations. In the SAM model, access to information is not only about availability and accessibility, but also about information that is clearly understandable and consumable by ordinary community members. SAM provides the means for citizens to access and process information, as well as cultivating the capacity and incentive to take action individually or collectively. 


\section{2}

Nguyahambi and Chang'a

Fifth, there are tensions between the ideal of the full legitimacy of CSOs to facilitate accountability interventions, and the practice of restricting and delegitimizing these activities by the government. In Tanzania, the government recognizes CSOs as important governance actors who play a vital role in promoting "active citizenship". Following the rapid political changes between the mid-1980s and early 1990s, Tanzania experienced a nationwide vibrancy in civil society in terms of an increase in number of CSOs and their respective activities. These operated with different levels of organizational and resource capacities. For example, by 2000, more than 8,000 CSOs were engaged in a range of different activities, including human rights, good governance, democracy, basic service delivery, environmental conservation, community development and poverty reduction. Generally, CSOs provided additional civic space to government-created avenues for citizen-state interaction.

Yet the legitimacy of CSOs' promotion of active citizenship collides with a restrictive environment that constrains their performance and expected outcomes in terms of meaningful citizen-state interaction. During its implementation of accountability monitoring activities, Sikika clashed with political officials (councillors) in Kondoa District Council, which led to sanctioning of Sikika's operations in the district. Councillors claimed that the ban was due to Sikika's "insulting" councillors by accusing them of being uneducated and therefore lacking the capacity to analyze issues in a comprehensive manner; Sikika, on the other hand, perceived the reason for the ban to be an intervention that indicated irregularities in the management of public resources, particularly health sector resources, which councillors did not want disclosed (Sikika 2015). Although Sikika was later allowed to continue operations, such a situation indicates that the district council had some reservations with regard to how far SAM activities should be allowed to extend. This partly explains the general preference among state institutions (in this case local government authorities) for retaining dominance in governance and service-delivery processes rather than favouring interventions that cultivate active citizen participation. It is apparent that the government considers CSOs important actors when they work on intervention projects that directly support improvements in service delivery, such as the construction of infrastructure and provision of other deliverables. Conversely, CSOs engaging in advocacy activities that seek to address non-tangible aspects of service delivery such as transparency and accountability are accorded limited cooperation.

\section{Conclusion}

We can draw three main conclusions based on our analysis of SAM. First, as it is promoted by Sikika and many other Tanzanian CSOs, SAM offers a model that promotes active citizenship involving ideas of direct participation, access to information and accountability. This implies the need for changes in current state-society interaction in contexts where the state has been the 
dominant actor in governance, such as in Tanzania. Second, we contend that SAM is able to facilitate some changes in citizen-state relationships. Adoption of the model has stimulated villagers to take part in governance and service delivery activities due to increased access to information, which cultivates citizens' confidence and readiness to engage in interaction with service providers. The increased participation of local communities has, in turn, promoted better public service delivery, as well as making public service providers accountable and responsive to citizens' demands. Third, there are, however, some discrepancies between ideals espoused by the SAM model and its practical application; these include its implementation through the participation of only a few invited community members, the reluctance of the service providers to collaborate, community members' inability to understand the accessed information and the de-legitimation of CSO mandates by government officials.

In conclusion, we argue that the successful implementation of SAM is always dependent on sufficient knowledge of existing state-citizen relations. In the Tanzanian context, this should include how to stimulate active citizen participation in order to influence decision-making processes and outcomes, especially at lower levels of governance. The implication for the design and implementation of SAM interventions, in any part of the world, is that an adequate analysis of the political, social and economic landscape in which implementation will take place is needed in order to instigate sustainable changes in the citizen-state relationship that will endure after the end of CSO facilitation; otherwise, as our analysis shows, the outcome might contradict the initial aims of improving that relationship. Essentially, social accountability interventions aim to promote the agency of citizen-based accountability initiatives that ultimately help to reinforce existing accountability mechanisms. An absence of political will at different levels of governance and inadequate official support for social accountability interventions can hamper the capacity for, and commitment to, activism among citizens and civil society actors, and discourage lobbying for the desired active citizenship. Therefore, rather than experiencing SAM as a "police work" by CSOs and citizens, it should be considered an acceptable accountability mechanism geared towards meaningful state-society interactions.

\section{Note}

1 Sikika is one among many Non-Governmental Organizations (NGOs) increasingly being recognized by the Government of Tanzania as important partners in nation building and national development, and valuable forces in promoting the qualitative and quantitative development of democracy. Sikika is a Swahili word, which literally means "to be heard". Its formal registration as an NGO took place in 2009 as a Limited Company, guaranteed under the Company's Act (2000). Legislatively, there is single law that governs registration of civic organizations in Tanzania. In addition to the Company's Act (2000), there is other legislation such as the NGO Act (2002), Cooperative Societies Act (2003) and the Societies Act (1954). While 


\section{Nguyahambi and Chang'a}

the NGO Act (2002) is currently the national-level instrument governing registered NGOs, many robust advocacy civic organizations consider registering under the Company's Act (2000) the best option because of what is said to be limited direct control and the strong-handedness of government. Since its establishment, Sikika has envisioned the realization of quality health services for all by reinforcing accountability and transparency in health resource management. Today, Sikika's organizational purpose is to enhance health and public finance systems through SAM and advocacy at all government levels.

\section{References}

Ahmad, R. (2008). Governance, social accountability and the civil society. Journal of Administration and Governance (JOAAG), 3(1), 10-21.

APRM (2011). Tanzania country self-assessment report. Dar es Salaam: African Peer Review Mechanism.

Brock, K., McGee, R. \& Gaventa, J. (Eds.). (2004). Unpacking policy: Actors, knowledge and spaces in poverty reduction. Kampala: Fountain Press.

Campbell, C., Comish, F., Gibbs, A. \& Scott, K. (2010). Heeding the push from below: How do social movements persuade the rich to listen to the poor? Journal of Health Psychology, 15(7), 962-971.

Claasen, M. \& Alpin-Lardies, C. (2010). Introduction. In M. Claasen \& C. AlpinLardies (Eds.). Social accountability in Africa: Practitioner's experiences and lessons. Cape Town: Affiliated Network for Social Accountability (ANSA - Africa).

Clippinger, E., Liang, C.J., Murray, I., De Burca, G. \& Fisher, A. (2014). Accountability through civic participation in post-2015 development agenda. United Nations Development Programme. Retrieved from www.undp.org/content/dam/undp/libra ry/MDG/Post2015-SDG/f_UNDP-NYU_Accountability-Post-2015_web.pdf

Colm, A. (2008). Strengthening accountability and service delivery in Tanzania: The case for rights-based social accountability monitoring. Dar es Salaam: HakiElimu.

Friis-Hansen, E. \& Ravnkilde, S.M.C. (2013). Accountability mechanisms and access to public service delivery in rural Africa. Copenhagen: Danish Institute for International Studies.

Gaventa, J. (2002). Introduction: Exploring citizenship, participation and accountability. IDS Bulletin, 33(2), 1-14.

Gaventa, J. (2004). Towards participatory governance: Assessing the transformative possibilities. In S. Hickey \& G. Mohan (Eds.). Participation: From tyranny to transformation? Exploring new approaches to participation in development (pp. 2541). London: Zed Books.

Gaventa, J. \& Barrett, G. (2010). So what difference does it make? Mapping the outcomes of citizen engagement. London: Institute of Development Studies.

Gaventa, J. \& McGee, R. (2013). The impact of transparency and accountability initiatives. Development Policy Review, 31(s1), 3-28.

Gaventa, J. \& Valderrama, C. (1999, June). Participation, citizenship and local governance: Background note prepared for workshop on "Strengthening participation in local governance". Institute of Development Studies. Retrieved from www.uv.es/ $\sim$ fernandm/Gaventa, $\% 20$ Valderrama.pdf

Green, D. (2012). From poverty to power: How active citizens and effective states can change the world. London: Oxfam International. 
Green, D. (2015). The Chukua Hatua accountability programme, Tanzania (Annual Programme Report). Oxford: Oxfam International.

Hickey, S. \& King, S. (2016). Understanding social accountability: Politics, power and building new social contracts. The Journal of Development Studies, 52(8), 1225-1240.

Hyden, G., Court, J. \& Mease, K. (2003). Civil society and governance in 16 developing countries (ODI, World Governance Survey Discussion Paper). Retrieved from www. odi.org/sites/odi.org.uk/files/odi-assets/publications-opinion-files/4098.pdf

Joshi, A. (2008). Producing social accountability: The impact of service delivery reforms. IDS Bulletin, 38(6), 10-17.

Joshi, A. (2013). Do they work? Assessing the impact of transparency and accountability initiatives in service delivery. Development Policy Review, 31(s1), 29-48.

Joshi, A. \& Houtzager, P. (2012). Widgets or watchdog? Public Management Review, $14(2), 145-162$.

Khadka, K. \& Bhattarai, C. (2012). Sourcebook of 21 social accountability tools. Program for Accountability in Nepal. Kathmandu: PRAN/World Bank.

King, S. (2015). Political capabilities for democratization in Uganda: Good governance or popular organization building? Third World Quarterly, 36(4), 741-757.

Lange, S., Wallevik, H. \& Kiondo, A. (2000). Civil society in Tanzania. Development Studies and Human Rights. Bergen: Chr. Michelsen Institute. Retrieved from www. cmi.no/publications/file/988-civil-society-in-tanzania.pdf

Lawson, A. \& Rakner, L. (2005). Understanding patterns of accountability in Tanzania (Final Synthesis Report). Oxford: Oxford Policy Management.

Lister R. (1998). Citizen in action: Citizenship and community development in a Northern Ireland context. Community Development Journal, 33(3), 226-235.

Malena, C. \& Chhim, K. (2009). Linking citizens and the state: An assessment of civil society contributions to good governance in Cambodia. Phnom Pehn: World Bank.

Malena, C. \& McNeil, M. (2010). Demanding good governance: Lessons from social accountability initiatives in Africa. Washington, DC: The World Bank.

Mattes, R. (2010). Controlling power - African' views on governance, citizenship and accountability. In M. Claasen \& C. Alpin-Lardies (Eds.). Social in accountability in Africa: Practitioner's experiences and lessons (pp. 8-24). Cape Town: Affiliated Network for Social Accountability (ANSA - Africa).

Mugizi, G. (2013). Interrogating social accountability in Tanzania: A case study. Rhodes University and Policy Forum. Retrieved from http://psam.org.za/research/ 1377269290.pdf

Ringold, D., Holla, A., Koziol, M. \& Srinivasan, S. (2012). Citizens and service delivery: Assessing the use of social accountability approaches in the human development sectors. Washington, DC: The World Bank.

Shankar, S. (2010). Can social audits count? ( ACARC Working Paper 09). Canberra: Australia South Asia Research Centre. Retrieved from https://crawford.anu.edu.au/a cde/asarc/pdf/papers/2010/WP2010_09.pdf

Sikika (2013). Ripoti ya Ufuatiliaji na Uwajibikaji kwa Jamii (SAM), Halmashauri ya Wilaya ya Kondoa (Dodoma). Dar es Salaam: Timu ya SAM Kondoa na Shirika la Sikika.

Sikika (2015). Annual report 2014. Monitoring and Evaluation Department. Dar es Salaam: Sikika Company Limited.

Sikika (2016). Ripoti ya Ufuatiliaji na Uwajibikaji kwa Jamii (SAM), Halmashauri ya Wilaya ya Kondoa (Dodoma). Dar es Salaam: Timu ya SAM Kondoa na Shirika la Sikika. 
226 Nguyahambi and Chang'a

UNDP (2010). Fostering social accountability: From principle to practice (Guidance Note). Oslo: United Nations Development Programme.

UNDP (2013). Reflections on social accountability: Catalyzing democratic governance to accelerate progress towards the Millennium Development Goals. New York: United Nations Development Programme.

World Bank (2003). World development report 2004: Making services work for poor people. Washington, DC: World Bank.

World Bank (2005). The effectiveness of World Bank support for community-based anddriven development: An OED evaluation. Washington, DC: World Bank.

World Bank (2007). Social accountability sourcebook. Washington, DC: World Bank. 


\title{
15 Conclusions
}

\author{
Tiina Kontinen and Katariina Holma
}

In the Introduction, we established three main objectives for this volume: a) to articulate a concept of citizenship based on philosophical pragmatism; b) to explore a variety of practices wherein citizenship habits are formed and reformulated; and c) to reflect on the interaction between the ideals of transformation and the actualization of incremental change in practice. The three sections of the book addressed these questions in a variety of ways: first, anchoring the concepts used in philosophical pragmatism; second, discussing citizenship practices and their circumstances in different locations in Uganda and Tanzania; and third, examining the discrepancies between ideals and practices in intentional attempts to change citizenship habits. In this chapter, we reflect on the fulfilment of these objectives, and further, on our contributions to the three motivating discussions presented in the Introduction.

\section{The concept of citizenship based on philosophical pragmatism}

The pragmatist stance on citizenship, inspired especially by John Dewey and adopted by the authors of this book, included, first, the methodological principle of producing conceptualizations as a result of dialogue between theories and lived experiences; second, an attempt to define citizenship as constructed in practices in which certain citizenship habits are acquired and formulated; and third, the requirement of contextualizing practices in their societal and historical circumstances (Holma \& Kontinen, this volume). Moreover, Rydenfelt (this volume) provided a pragmatist conceptualization of democracy distinct from elitist and deliberative views, in which democracy is not primarily voting or participation in public deliberation, but social inquiry into shared issues often perceived as social problems. Kauppi et al. (this volume) then connected social inquiry with a Deweyan notion of intelligence, in which it is defined as fundamentally social, manifesting and cumulating in interaction and playing a crucial role in action and shared problem solving. Ultimately, anchored in pragmatism, we articulated a conceptualization of citizenship which starts with lived experiences, and complements the three perspectives prevalent in research: citizenship as a status, as participation or as identity (Holma \& Kontinen, this volume). The definition provided 


\section{Kontinen and Holma}

understands citizenship as constructed in practices taking place in communities involved in the public, thus, in shared activities that have the aim of taking care of shared issues, thereby realizing citizenship habits both acquired and reformulated, thus learned, in the course of taking part in these communities.

This conceptualization offers fresh perspectives for theoretical and empirical research on citizenship by extending its realm to activities that have been taken as non-political, and thus, not necessarily included in the notion (Isin \& Nyers 2014), nor paid much attention to in the transformative agendas of citizen participation in development research (Hickey \& Mohan 2004). The conceptualization drew on Deweyan theorization of citizenship as starting from participation in various communities which take care of shared concerns - rather than in political procedures or claim making - which implies an approach that does not make a sharp distinction between private and public activities. This view helped us to see that various practices in people's everyday lives form a network where shared issues are jointly addressed, and enabled us to view the practices of participation as arenas of learning habits that can also be useful in other, more clearly political activities. We also highlighted the pragmatist notion of circumstances in relation to practices and habits of citizenship, as both social and political contexts define what is understood by citizenship and how it is, and can be, practiced in the first place.

These ideas were paralleled by our empirical investigations, where it became evident that, especially in rural contexts, people actively organize themselves around shared concerns, such as livelihood challenges or boosting agricultural productivity, but participate to a lesser extent in what could be regarded as political activities in the narrow sense. Further, in accordance with development research (Gaventa \& Barrett 2012), we observed that organizing connected with shared issues might also have "political" consequences in terms of getting participants' voices heard in local politics, gaining agency and self-confidence, and achieving an understanding what politics at different levels is about. Meanwhile, the Deweyan idea of democracy as social inquiry rather than voting or deliberation emphasizes that citizens' organizing revolves around issues experienced as problematic, comprising shared experimentation in seeking new solutions. In social inquiry, everyone's experience can contribute to solving shared problems and everyday concerns, which may also enable the expansion of future possibilities for action: for instance, women originally coming together over small-scale livelihood problems may gradually develop competencies and a reputation for competence that allows them to have their voices heard on village issues.

\section{Practices and habits of citizenship in different locations}

During our research project, we relied on the methodological principles of pragmatism to explore lived experiences of citizenship. On the pragmatist 
basis, and in interaction with empirical research, we developed notions of practices and habits as conceptual tools to further our investigation of lived experiences; however, while focusing on experiences and local practices, it was also important to understand the circumstances in which these practices took place. The contextualizing chapters on Uganda (Alava et al.) and Tanzania (Nguyahambi et al.) show that these two neighbouring countries have quite different historical circumstances that effect contemporary practices and habits of citizenship. While both countries share a colonial history, advancement of state-citizen relations in their post-independence trajectories have been different. African socialism and explicit nation-building in a quest to include every citizen in the project of "maendeleo" have characterized Tanzania, while Uganda has more explicitly dealt with religious, ethnic and areabased struggles, including violence on many fronts.

Therefore, we should be careful when speaking of "African citizenship", or even of citizenship habits in a particular country, as contemporary citizenship experiences may vary according to region. For instance, the "subdued citizenship" (Alava, this volume) prevalent among the Acholi in northern Uganda, might not resonate with contemporary experiences and habits of citizenship in the southern part of the country. The diversity of citizenship also follows gendered lines. As Ndidde et al. (this volume) show, while women hold a certain "universal" legal status that equals that of men in Uganda, lived experiences and cultural practices in different localities can be quite diverse according to gender. We also learned that lived experiences of citizenship are often related to residence in one's immediate community, while experience of membership in the state remains distant. Additionally, as Nguyahambi and Kontinen (this volume) conclude, those belonging to a religious community can make connections between the morals specific to their religion and the general civic virtues essential for a good citizen conversant with Tanzanian political history.

The chapters also showed that citizenship habits acquired in local practices have characteristics that are quite different to the ideals of liberal, universal, individual citizenship of claiming rights from duty-bearers (Robins et al. 2008). Islamic communities in rural Tanzania supported community-centred and harmony-seeking habits (Nguyahambi \& Kontinen); self-help groups revolved around addressing everyday livelihood problems, which strengthened habits of contributing citizenship (Kilonzo et al.); while women in rural Uganda partly excluded themselves from their conceptualization of citizenship (Ndidde et al.). These localized practices and the citizenship habits acquired in them should be taken into account when designing interventions aiming to change citizenship habits in the direction of a desired ideal. As Nguyahambi and Chang'a show, an NGO attempt to promote citizenship that will engage with holding service providers accountable, can be countered by prevailing habits and, while some activities may change, this trend tends to lapse when the NGO is no longer present. 
A quite self-evident, yet important, conclusion in regard to citizenship practices and habits is that usually an individual participates in a number of practices involving potentially different habits. For instance, in Kondoa in Tanzania, the same person can learn the habits of a contributing citizen in a self-help group, of a harmony-seeking citizen in an Islamic community and of an active, engaged citizen in a social accountability project initiated by an NGO. Overall, it seemed that some individuals are quite active in many communities, while others remain more passive when it comes to addressing shared issues; furthermore, those active on many fronts were able to take their experiences from one group to another. Individual habits are formed through these different trajectories of participation, and individuals can promote change in any particular practice by articulating innovative ideas derived from other practices, thereby contributing to social intelligence that might expand the possibilities of future action (Kauppi et al.). Moreover, practices and habits are not static, but can dynamically change, especially in a new situation where the existing habits no longer seem to work, as Kontinen and Ndidde demonstrated in the context of organizational habits in a gender advocacy NGO. Ultimately, the pragmatist notion of citizenship counters the projection of people as agentless manifestations of social habits, suggesting that, notwithstanding the stickiness of habits, they can be reformulated through reflection and experimentation with "doing it differently" if they are experienced as inadequate and ill-functioning.

\section{Ideals of transformative change and practice of incremental change}

Our initial framework of growth into citizenship (Holma, Kontinen \& Blanken-Webb 2018) focused on learning as a change of habits originating in a disruption of older ways of thinking and acting. Interventions that involve some kind of citizenship education can be seen as aspiring to provide a disruption in order to initiate change and are often based on the ideas of transformative learning in which old habits are supposed to change at a fundamental level. As Dewey argues, habits are difficult to change (Dewey 1927, 336-337), and our examples demonstrate that implementing transformative ideals that encounter prevalent practices and habits, often results in incremental rather than transformative change. The interaction between ideals and their actualization was a consideration of the participatory research methodology of the Ugandan research team (Ahimbisibwe et al.), gender equality as a core concern of a Ugandan NGO was investigated by Kontinen and Ndidde, principles of critical education implemented by a Ugandan NGO were the concern of Bananuka and John, and a social accountability monitoring programme initiated by a Tanzanian NGO the province of Nguyahambi and Chang'a.

The application of participatory research methodology aimed to level the traditional power relations between the academic researchers and "local" research participants (Ahimbisibwe et al.). While the approach succeeded in 
appreciating the unique experiences of participants and providing them with the empowering experience of analyzing their own situations, the research process involved continual struggles with presuppositions concerning "elite researchers", and practices that, often unintentionally, strengthened these presuppositions. Indeed, Kontinen and Ndidde analyzed how an NGO seeking transformative change in gender relations had learned to deal with precisely this concern, as well as becoming used to seeing incremental rather than transformative change. Consequently, its organizational learning was not so much about clarifying objectives and measuring them with systemic monitoring and evaluation, but about continuous engagement with practices and being ready with an ongoing response to problematic situations.

At the same time, the experiences of the rural women who were beneficiaries of this particular NGO demonstrated that gender roles were not likely to transform rapidly from an imbalanced state to one of equality (Ndidde et al.). On the contrary, they were prone to change gradually, sometimes as a result of participation in new practices arranged by an NGO that have provided innovative ideas and examples of how gender relationships can be constructed. Another Ugandan NGO developed an idea of critical education as an alternative to its traditional support for livelihoods and in order to promote transformative development (Bananuka \& John). However, practical initiatives based on the new pedagogical philosophy had to struggle continually with contextual forces related to the government, donors and prevailing culture. Similarly, Nguyahambi and Chang'a showed how the promotion of a social accountability monitoring (SAM) model by an NGO encountered habits in the prevailing citizen-state relationship characterized by state domination in governance. These were not fundamentally changed as a result of the intervention, which promoted active citizenship and direct participation, meanwhile demanding accountability from service providers; however, some disruptions and alternative models were provided which could, potentially, be used in other spheres in the future.

The main conclusion we can draw from these contextualized analyses is that the introduction of new ideals - for instance, by means of training and awareness raising - does not necessarily suffice to promote change. As Dewey (Dewey 1922, 88-91; Hildreth 2012) suggests, any effort to change habits is intertwined with the task of changing circumstances. Pragmatist ideas indicate that change often takes place in a long-term interaction between habits and circumstances and, therefore, changing only one side of the coin does not suffice. In relation to the habits of gendered citizenship, the example from rural Uganda (Ndidde et al.) showed that change in the legal circumstances governing gender equality might not necessarily become apparent in local practices. At the same time, the example of the gender NGO (Kontinen \& Ndidde) indicated that channelling lived experiences from rural areas to decision makers, can contribute to changes in the legal circumstances. Nonetheless, attempting to insert NGO interventions based on certain ideals - such as gender equality or empowered citizens - into prevailing habits can result in 


\section{Kontinen and Holma}

frustration with the slow pace of change and lack of transformation. This is exacerbated by the need to report quick and impressive results and outcomes to the donors who often require transformative change, ideally achieved during a program cycle.

In conclusion, based on our research, we contend that changing citizenship habits is largely a gradual process taking place over an extended period of time. Moreover, we suggest that, on the one hand, if interventions focus too much on implementing certain ideals, they might not be experienced as relevant, and, on the other, that without an input that disrupts existing habits, a need for change might not be experienced. NGO interventions, at their best, should create a joint community of inquiry, including both external experts and the people whose lives are at stake, and together formulate ends-in-view (Dewey 1922, 154-163) that address disruptions in existing habits that have been experienced, and initiate changes in existing practices to realize those ends-in-view. The pragmatist approach to social change therefore differs both from the blueprint project-implementation model where "modern" experts play a central role, and from the models of building on popular participation while dismissing outside expertise, thus emphasizing the productivity of bringing together different perspectives.

\section{Contributions to development research}

Our main conceptual contribution to development research was the pragmatist framework, which, to our knowledge, has not been previously used in the field. The pragmatist approach offered new points of view, meanwhile confirming some previous results of development research. For instance, the need to take differences in contexts seriously has been continually articulated in the field of development research and practice (Davies 2004). However, both development research and practice easily fall back on using universal ideals and approaches, which start to play the role of "buzzwords" to be adopted in each context participating in the aid system (Cornwall 2007). Thus, the Deweyan critique of applying a solution proved in one context directly to another, without inquiry into the particular conditions (Kauppi et al.), is especially valid for the field. The critique makes it clear that an intervention model perceived to be successful in one context might not be appropriate for another, and that delving into the particular habits and circumstances is essential.

Additionally, Dewey's concept of ends-in-view (Dewey 1922, 154-163) provides a useful new angle. He stressed that envisioned ends and values should also depend on the context and actual situation, and, therefore, should be negotiated in a process of shared inquiry. According to this view, people cannot espouse predefined ends that are entirely independent of the context; therefore, intervention approaches that hold to certain, fixed goals are hampered by the fact that these are not jointly negotiated from the very start. The extensive discussion of participation and participatory approaches in 
development has addressed this issue (Chambers 1997; 2008), but, in practice, many projects invite people to participate within already established frameworks rather than defining the entire direction of change from the very beginning (Gaventa 2004). Instead, these negotiations over shared issues and good citizenship can take place in the course of practices connected with religious communities or self-help groups that have no direct connection to the development apparatus, and are not initiated by any external development actor.

The pragmatist concept of practice also provides a perspective onto aspirations for change and transformation typical of development research, as existing habits and the experiences on which they are based generally gain relatively little attention in such attempts. Pragmatist notions of experience, practice and habit prompt analysis to take into account continuities between the past, present and future, and the intertwining of habits and circumstances. This theoretical stance points to gradual, long-lasting change in "sticky" habits rather than indicating that nothing can change; on the contrary, it emphasizes the possibility of change in the course of joint inquiry into experienced challenges. The implication here is that people tend to organize around, seek new knowledge about, and experiment with new ways of doing things, in relation to issues that are significant and relevant for them; in rural contexts, for instance, these are often related to livelihood and income on the one hand, and to social gatherings such as weddings and funerals on the other. Therefore, for any intervention seeking to promote change, engaging with these existing forms of organizing (Lewis 2002; Kontinen \& Millstein 2017) offers promising opportunities, in pragmatist terms, to form communities of inquiry, and introduce disruptions to existing habits - or, in the terminology of development, to initiate sustainable development based on ownership by local communities.

Contributing to current debates concerning the need for change in development research itself, we can provide a few conclusions on the basis of our joint inquiry. In terms of North-South partnerships, we experimented with a few practical measures. In order to counteract the usual asymmetries, we invested financial resources in joint meetings and seminars for the entire research team. We met in Finland, Tanzania and Uganda to discuss the concepts and action plan, the field methods, the initial analysis of the data and the first and second drafts of the chapters of the book. In this way, we avoided adhering to the traditional model of realizing a blueprint plan designed by Northern partners, leaving Southern researchers mostly in the role of data collectors (Carbonnier \& Kontinen 2015). Eventually, the entire preparation of this volume demonstrated joint effort and involvement in real co-authorships, thereby addressing African scholars' lack of voice and presence in international academic publications (Briggs \& Weathers 2016; Melber 2019). The collaboration could not escape the institutionalized asymmetries in terms of funding sources and the requirements set by different academic environments. 


\section{Kontinen and Holma}

\section{Contributions to pragmatism}

The key idea of philosophical pragmatism is to begin with practices and keep theorization in close and bidirectional contact with empirical reality; however, not many philosophers who claim to be pragmatists actually start their theorizations from empirical research into real-life practices. Consequently, our pragmatist "experiment" may serve as an example of putting these principles of pragmatism into practice. We were able, although far from perfectly and in a process that was not without problems, to bring philosophical theories into dialogue with empirical research in the two contexts of Uganda and Tanzania, and develop our concepts of practice and habit based on this dialogue.

The Deweyan philosophy on social inquiry stresses the role of context, but leaves a couple of questions, which turned out to be crucial in our research, quite untouched. The first is how to make sense of complex contextual factors in different empirical settings: that is, what kind of dimensions and levels should researchers take into account in order to have a sufficient grasp of the context? Secondly, the Deweyan theory of education and societal change (citizenship and learning), seems to presuppose institutionally democratic settings and relatively extensive public education. This is not a good fit in contexts where these presupposed conditions are not necessarily a part of social and political reality. As Rogers $(2009,2)$ points out, although Dewey stresses the idea of democracy as an associate mode of living that starts from communities which take care of shared concerns, he obviously presumes statelevel democracy as the wider context in which the associate mode of living takes place. This necessitates sensitivity when theories are brought into dialogue with different circumstances and contexts from those in which the theories were first developed. While pragmatist ideas, such as applying the methods of democracy in communities of inquiry, are also suitable for circumstances where the state institutions might be non-democratic, restrictions on citizens' freedom of assembly and speech undoubtedly have implications for the nature of the "shared issues" one can address in these communities, and whether they are permitted in the first place.

Engaging in dialogue with contexts which are different from the historical background of pragmatism underlines the need to articulate what is actually meant by environments and circumstances. Pragmatism argues for contextualization but, implicitly, seems to hold certain presuppositions - at least concerning political systems and levels of education - to be universal. The problem with regarding European and North American experiences and circumstances as universal in theorizing is well-known from, for instance, the postcolonial critique (Go 2016); however, for pragmatism, detailed inquiry into circumstances would not only respond to such critiques, but actually put its own theoretical principles to work. Our own investigation demonstrated the complexity of the question of circumstances, and how important it is for a researcher to familiarize herself with them, not only at the level of practice 
but also when theorizing, in order to be more explicit about definitions of environments and circumstances, and their relationship to practices.

\section{Back to the question of learning}

To conclude, we want to revisit our initial endeavour to study learning in relation to citizenship, and more specifically, growth into citizenship from the perspective of pragmatism (Holma, Kontinen \& Blanken-Webb 2018). Exploring growth would have required the identification of moments when habits were reformulated as a response to disruption. In the course of the project, we realized that examining this kind of learning in everyday life, without conducting an educational intervention in order to promote it, is challenging. At best, such learning could be identified retrospectively on the basis of people's narratives in individual and group interviews. As a consequence, we increasingly focused on the practices in which habits are formulated, and moved from emphasizing change - and thus learning - in citizenship towards exploring how certain citizenship habits are acquired and maintained within the space of joint practices.

The challenges we encountered are connected with some more general challenges in researching learning as a social and societal phenomenon. While it is comparatively easy to measure if an individual has learned something specific, such as literacy, examination of the learning of citizenship competencies as a result of overall life trajectory (Dahlgren 2006) is far more complicated. Moreover, an interest in kind of learning that takes place in everyday life increases the methodological challenges. There is considerable research on transformative learning in development contexts (Skinner et al. 2016), for instance - that focuses on learning that takes place in the context of implemented educational interventions where such learning is explicitly promoted; thus, following the learning trajectories from the point of intervention structures the analysis. However, even in this kind of research, it is difficult to follow up the long-term changes that result from learning in educational interventions, and to trace how the transformative action spreads across different spheres of life.

The Deweyan approach differs from many approaches to education, ranging from the Christian to the Marxist, in which learning is supposed to lead to the total transformation either of a person (e.g. Mezirow 2000) or the power relations in a society. Such approaches, often openly utopian, provide a certain ideal for the end state of learning and, thus, can mobilize and inspire people to move towards these ideals. In contrast, Deweyan philosophy can be seen as an alternative to such utopias as it emphasizes gradual change and the continuities between the past and future. At the same time, it could be claimed that the Deweyan view of people participating in social inquiry in a democratic manner is also a utopian vision if it does not successfully take into account the circumstances that might limit joint organizing, or is not sensitive to the hegemonizing of certain "shared problems" or certain points of views over others (Holma \& Kontinen 2015). 


\section{Kontinen and Holma}

Therefore, our observation is that investigating learning not only as an individual, cognitive process, but as something that takes place in its social and societal contexts and aims at new habits of thought and action in the social and political realm, is a challenging task. However, it is a task that is much needed in order to strengthen citizenship in particular, and it is crucial in development interventions in general. It is also an important element when attempting to understand the intertwined nature of individuals, communities and circumstances and also in in-depth inquiry into the conditions in which learning is supposed to take place. There is a wealth of interesting research to be done from different theoretical perspectives in further conceptualizing learning, research that is anchored in empirical investigations in different contexts. Therefore, we do not consider the research discussed in this volume an end, but, rather, a humble beginning to the difficult and important work that continues.

\section{References}

Briggs, R. \& Weathers, J. (2016). Gender and location in African politics scholarship: The other white man's burden? African Affairs, 115(46), 466-489.

Carbonnier, G. \& Kontinen, T. (2015). Institutional learning in North-South research partnerships. Revue Tiers Monde, 2015/1(221), 149-162.

Chambers, R. (1997). Whose reality counts?London: Intermediate Technology Publications.

Chambers, R. (2008). Revolutions in development inquiry. London: Earthscan.

Cornwall, A. (2007). Buzzwords and fuzzwords: Deconstructing development discourse. Development in Practice, 17(4/5), 471-484.

Dahlgren, P. (2006). Doing citizenship. The cultural origins of civic agency. Cultural Studies, 9(3), 267-286.

Davies, R. (2004). Scale, complexity, and the representation of theories of change. Evaluation, 10(1), 101-121.

Dewey, J. (1922). Human nature and conduct: An introduction to social psychology. In J.A. Boydston (Ed.). The middle works of John Dewey (Volume 14, pp. 1-230). Carbondale: Southern Illinois University Press.

Dewey, J. (1927). The public and its problems. In J.A. Boydston (Ed.). The later works of John Dewey (Volume 2, pp. 235-372). Carbondale: Southern Illinois University Press.

Gaventa, J. (2004). Towards participatory governance: Assessing the transformative potentials. In S. Hickey \& G. Mohan (Eds.). Participation: From tyranny to transformation? Exploring new approaches to participation in development (pp. 25-41). London: Zed Books.

Gaventa, J. \& Barrett, G. (2012). Mapping the outcomes of citizen engagement. World Development, 40(12), 2399-2410.

Go, J. (2016). Postcolonial thought and social theory. Oxford: Oxford University Press.

Hickey, S. \& Mohan, G. (Eds.). (2004). Participation: From tyranny to transformation? Exploring new approaches to participation in development. London: Zed Books.

Hildreth, R.W. (2012). John Dewey on experience: A critical resource for the theory and practice of youth civic engagement. Citizenship Studies Volume, 16(7), 919-935. 
Holma, K. \& Kontinen, T. (2015). The rocky road of growing into contemporary citizenship: Dewey, Gramsci, and the method of democracy. Studier i Padagogisk Filosofi, 4(2), 24-37.

Holma, K., Kontinen, T. \& Blanken-Webb, J. (2018). Growth into citizenship: Framework for conceptualizing learning in NGO interventions in sub-Saharan Africa. Adult Education Quarterly, 68(3), 215-234.

Isin, E.F. \& Nyers, P. (2014). Introduction: Globalizing citizenship studies. In E.F. Isin \& P. Nyers (Eds.). Routledge handbook of global citizenship studies (pp. 1-11). London: Routledge.

Kontinen, T. \& Millstein, M. (2017). Rethinking civil society in development: Scales and situated hegemonies. Forum for Development Studies, 44(1), 69-89.

Lewis, D. (2002). Civil society in African contexts: Reflections on the usefulness of a concept. Development and Change, 33(4), 569-586.

Melber, H. (2019). Knowledge production, ownership and the power of definition: Perspectives on and from sub-Saharan Africa. In I.E. Baud, T. Kontinen \& S. von Itter (Eds.). Building development studies for the new millennium (pp. 265-287). Cham: Palgrave Macmillan.

Mezirow, J. (2000). Learning as transformation: Critical perspectives on theory in progress. San Francisco, CA: Jossey Bass.

Robins, S., Cornwall, A. \& von Lieres, B. (2008). Rethinking 'citizenship' in the postcolony. Third World Quarterly, 29(6), 1069-1086.

Rogers, M. (2009). The undiscovered Dewey: Religion, morality and the ethos of democracy. Chichester: Columbia University Press.

Skinner, A., Baillie Smith, M., Brown, E. \& Troll, T. (Eds.). (2016). Education, learning and the transformation of development. London: Routledge. 


\section{Index}

Note: page numbers in italic type refer to Figures; those in bold type refer to Tables.

Academy of Finland 7

Access to Information Act 2016, Tanzania 214

accountability 211-212; see also SAM

(social accountability monitoring), and active citizenship

ACFODE (Action for Development)

105, 109, 162, 168, 230, 231; advocacy

approaches 185-187, 189; introduction

and overview of 179-180;

organizational learning study 177 ,

180-190; organizational restructuring

187-189; and patriarchal habits

180-183; project implementation

habits 183-185, 189; see also gendered citizenship, Uganda; participatory research, Uganda

Acholi region, northern Uganda see subdued citizenship, northern Uganda

ACT - Wazalendo (Alliance for Change and Transparency), Tanzania 80

action research 159

active citizenship 4-5, 8, 16, 21; barriers to 24; Tanzania $82,83,123,134,139$, 150, 151; Uganda 65, 67, 68, 90, 106, 114, 161; see also SAM (social accountability monitoring), and active citizenship

adult education 197-198; see also EDF

(Emesco Development Foundation), and critical education in Uganda

aesthetic response, Dewey's concept of 16

"African citizenship" 229

African studies literature 24

Ahikire, J. 109

Ahimbisibwe, Karembe F. 9, 57-72, 105-120, 159-175, 229, 230-231
Ahmed, F. 123

Alava, Henni 7, 9, 57-72, 90-104, 229

All Muslim National Union of

Tanganyika (AMNUT) 125

Alliance for Change and Transparency (ACT - Wazalendo), Tanzania 80

Alpin-Lardies, C. 215

Amin, Idi 59, 61, 65, 93, 94

AMNUT (All Muslim National Union of Tanganyika) 125

Anderson, D. M. 63

Anderson, E. 38

Anglican (Protestant) Church, Uganda 60, 62-63, 90, 116, 196

Ankole kingdom, Uganda 57, 58

anthropology 2; of citizenship 18, 19

anticipatory development 81

Anti-Terrorist Act 2002, Uganda 64

Ari Kasi Nguvu Mpya group, Tanzania 143-144, 145

Arusha Declaration 1967 75, 76

Asians, expulsion of from Uganda, 197261

authority, respect for (Islamic moral) 133 autochthony 24

Aziz, D. 125

Bananuka, Twine H. 7, 9, 57-72, 194-208, 229, 230, 231

"banking education" 202

Banks, N. 145, 151, 204

Banyarwanda group, Uganda 59

Barrett, G. 139, 151, 216

Berryman, M. 160

Bohman, J. 39

"Born Again" churches, Uganda, women's involvement in 116 
Brandi, U. 178

Bretton Woods Institutions 78

Brock, K. 219

Buganda kingdom, Uganda 57, 58, 59,92

Bunyoro kingdom, Uganda 57, 58

Bush War 1981-1986, Uganda 59

Busingye, J.D. 200

Butler, Judith 92

Catholic Church, Uganda 60, 62-63, 91, 94, 99, 100, 116, 196

CBOs (community-based organizations), Tanzania 141

CCM (Chama cha Mapinduzi), Tanzania 73, 77, 79, 80, 81, 82, 83, 85, 125, 145

CDWs (Community Development

Workers), EDF 198, 200, 202, 203

Chabal, P. 24

Chagga ethnic group, Tanganyika 74

Chama cha Mapinduzi (CCM), Tanzania 73, 77, 79, 80, 81, 82, 83, 85, 125, 145

CHAMEDA (Chama cha Demokrasia ne Maendeleo), Tanzania 80

Chang'a, Haji H. 9, 73-89, 139-155, 210-226, 229, 230, 231

charity (Islamic moral) 129

China 91

circumstances 23-24, 25, 234-235

citizenship: anthropology of 18,19 ; and democracy 38-40; dimensions of 18 ; feminist critiques of 20,106 ; as a legal status 105, 106, 107-109, 227; as lived experience 105, 106-107; local

definitions of 7 ; normative element of 23; and philosophical pragmatism 227-228; practices of 15, 16, 17-21, 23-24, 228-230, 233; religious dimension of in Uganda 168, 169, 169; Stanford Encyclopedia of Philosophy definition 18; as a theme 1, 4; see also habits of citizenship

Civic United Front (CUF), Tanzania 80

civic virtues see Islamic morals and civic virtues in Tanzania

civil society 1 ; role of in development 2 ; Uganda 66-67; see also CSOs (Civil Society Organizations); NGOs (non-governmental organizations)

Civil Society Organizations (CSOs), Tanzania 80-81, 82-83, 213-223

Claasen, M. 215

Clarke, J. 19, 20-21

Cohen, J. 31 co-learning, in participatory research $168-169,169$

colonialism: Tanzania 74-75, 124-125;

Uganda 57-58, 65, 93; and violence 91

communitarianism 18, 20

communities of inquiry 176, 178, 232

community: concept of 15 ; and Dewey

$19,20,24,178$

community confidence 216

community development, and education

194, 195, 197

Community Development Workers

(CDWs), EDF 198, 200, 202, 203

community involvement (Islamic moral)

129, 133-134

community willingness 216

conscientizing education 194, 197,

199, 202

consent, in participatory research 163

contributing citizenship: self-help groups,

Tanzania 141, 150-152

corruption, unacceptability of in Islam

131-132

critical education 159, 194, 197; see also

EDF (Emesco Development

Foundation), and critical education in

Uganda

critical theories 4

CSOs (Civil Society Organizations),

Tanzania 80-81, 82-83, 213-223

CUF (Civic United Front), Tanzania 80

Cybercrime Act 2015, Tanzania 82

Datzberger, S. 65

decency (Islamic moral) 130

democracy 9, 227; citizens role in 38-40; deliberative 30-32, 35, 38, 40; Dewey's concept of 34-35, 36, 39, 40, 228, 234; élitist 30, 40; issues in 29; liberal 30 , 34,37 ; meaning of 30 ; "method" of 24-26, 40; and pragmatism 30, 31-32, $34-40,41$; and social inquiry $32-34$, 36, 39-40, 40-41, 228

Democratic Party, Uganda 60

democratization 5

descriptivity 3,32

development practice 4-6

development research 1, 2-3, 6, 18, 228; contributions to 232-233

Dewey, John 3, 15, 227, 228, 235; and community 19, 20, 24, 178; and democracy 34-35, 36, 39, 40, 228, 234; and disruption 16, 48, 178;

ends-in-view 16, 17, 33, 232; growth 
theory 16, 176; and habits 16, 21-22, $23,25,140,152,178,182,184,230$, 231; and political philosophy 31 ; and the public 19-20, 21, 24, 49; and social inquiry $30,32-34,36,39-40,50-51$, 228, 234, 235; and social intelligence $9,44-52,227$; and the social nature of human knowledge 19, 20

disruption: and ACFODE 184; Dewey's concept of 16, 48, 178; and gendered citizenship, Uganda 114-117

diversity see ethnic diversity

Dolan, C. 93

Domestic Violence Act 2010, Uganda 109

Easterby-Smith, M. 176

economic self-sufficiency (Islamic moral) 132-133

EDF (Emesco Development

Foundation), and critical education in Uganda 9, 194, 205, 230, 231; context, role of 203-205; emergence of critical adult education 197-202; making of

195-196; multiple contexts of 196-197

education: and intelligence 48, 50-51;

Tanzania 74, 76, 83; Uganda 9; see also critical education

Elkjaer, B. 178

Emesco Development Foundation, and critical education in Uganda see EDF (Emesco Development Foundation), and critical education in Uganda

empowerment 4; and critical education 194, 201; in participatory research 170-171

ends-in-view 16, 17, 33, 232

engaged excellence 2

Englund, H. 140

environmental movement, Uganda 66

ethnic diversity: sub-Saharan Africa 23-24; Tanzania 74, 75, 142;

Uganda 196

ethnicity, and concepts of citizenship in Uganda 111-112

evolutionary theory, and social intelligence 44, 45

experience, and intelligence 46,49

fallibilism, and pragmatism 23

family lineage, and concepts of citizenship in Uganda 111-112

Fanon, Franz 91

Finnström, S. 96
Fisher, J. 63

forgiveness (Islamic moral) 129-130

Freire, Paulo 99, 159, 197, 199, 201, 202

Friis-Hansen, E. 216

Gaventa, J. 44, 139, 151, 210, 216, 219

gender: and Islamic morals and civic virtues in Tanzania 127; self-help groups, Tanzania 139, 148-149

gender-based violence 181, 182

gendered citizenship, Uganda 9, 57, 105-107, 117-118, 229, 231; and community involvement 115-117; and legal status 107-109, 114, 117; and lived experience 109-117; localized understandings of citizens/citizenship 110-112; women's self-exclusion $112-113,114$

Global North: North-South power asymmetries in development research $7-8,233$

Global South: and development research 3; North-South power asymmetries in development research 7-8, 233

globalization, and critical education in Uganda 204-205

governance 5; abuse of power 217; and accountability 211-212; hybrid governance, Uganda 60-61; see also SAM (social accountability monitoring), and active citizenship

Green, M. 81, 146-147, 151

GROW research project see "Growth into citizenship in civil society encounters" research project (2015-2019) (GROW research project) growth into citizenship concept 16-17, 230, 235

"Growth into citizenship in civil society encounters" research project (2015-2019) (GROW research project) 2, 7, 8; empirical research material collected 8; participatory research 160,161

growth theory (Dewey) 16

Habermas, Jürgen 31

habits: concept of 15, 16; Dewey's concept of 16, 21-22, 23, 25, 140, 152, 178, 182, 184, 230, 231; gendered citizenship 105, 112-114; of implementation 183-185; and intelligence 48; and learning 21-22, 25; patriarchal 180-183 
habits of citizenship 227, 228-230; and circumstances 23-24; definition 140; gendered citizenship 105, 112-114; self-help groups, Tanzania 139, 140, 150-152

hadith 127

HakiElimu 82

Halstead, J.M. 128, 134

harmonious citizenship, and Islamic morals 135

health service delivery see SAM (social accountability monitoring), and active citizenship, Tanzania

helping (Islamic moral) 129

Hickey, S. 67

hierarchical (non-democratic) societies 36,37

Holma, Katariina 1-12, 15-28, 44-54, 227-237

honesty (Islamic moral) 130

Hulme, D. 204

hybrid governance, Uganda 60-61

hypotheses 38,39

IMF (International Monetary Fund) 78, 79,210

indigenous knowledge, Uganda 199-200, 202, 203

individuals, and intelligence 45-46

information, right of access to 211 , 214-215, 220, 221

institutional wrestlings 177 ; and organizational growth 178-179, 189-190

intelligence: as an individual possession 45, 46; and education 50-51; elitist conception of $45,49,51$; and experience 46, 49; and habits 48; and social inquiry 48; see also social intelligence, Dewey's concept of

international development: and religion 122-124; and self-help groups 141-142

International Monetary Fund (IMF) 78, 79,210

Isin, E.F. 20

Islam, in Uganda, women's involvement in $116-117$

"Islamic civil society" 123

Islamic morals and civic virtues in Tanzania 121-122, 126-135, 229; gendered differences in 127, 131; identifying Islamic morals 128-130; international development context 122-124; overview of Islam in
Tanzania 124-126; religious morals and civic virtues $130-134$

James, W. 3, 31

Jitegemee group, Tanzania 143, 149, 150

John, Vaughn M. 7, 9, 194-208, 230, 231

Kabeer, N. 18

Kagadi district, Uganda see EDF (Emesco Development Foundation), and critical education in Uganda

Kakumiro district, Uganda see EDF (Emesco Development Foundation), and critical education in Uganda

Kane, L. 204-205

Karlström, M. 58, 92

Kassimir, R. 63

Kauppi, Veli-Mikko 9, 44-54, 227, 230, 232

Kelinman, A. 91

Kelinman, J. 91

Kibaale district, Uganda see EDF (Emesco Development Foundation), and critical education in Uganda

Kiboga District, Uganda see gendered citizenship, Uganda; participatory research, Uganda

Kilonzo, Rehema G. 9, 73-89, 139-155, 229

King, S. 152

Kiswahili, as national language of Tanzania 74, 77

Kitgum town, Uganda see subdued citizenship, northern Uganda

knowledge: indigenous knowledge, Uganda 199-200, 202, 203; and lived experience 49-50; social nature of 19, 20, 22; see also intelligence; social inquiry

Kondoa District, Tanzania 9 see SAM (social accountability monitoring), and active citizenship, Tanzania

Kontinen, Tiina 1-12, 15-28, 44-54, 57-72, 73-89, 105-120, 121-138, 139-155, 159-175, 176-193, 227-237

law-abiding behaviour (Islamic moral) 132

LDUs (Local Defence Units), Uganda 64

Le Mat, M. 65

learning 235-236; and habits 21-22, 25; and intelligence 48

learning organizations 176; see also organizational learning 


\section{Index}

legitimacy, of governments 30-31

Lewin, K. 159

Leydet, D. 18

liberal democracy 30

liberalism 18, 30-31

Liberalism and Social Action (Dewey) 34

liberating education 194, 197, 202

Ling, S. 67

linguistic diversity, sub-Saharan Africa 24

Lister, R. 211

Local Defence Units (LDUs), Uganda 64

localized citizenship, Uganda 57

Locke, John 30

Loimeier, R. 122, 127

LRM/A (Lord's Resistance Movement/

Army), Uganda 59, 90, 92-93, 94, 95

Lyle, M.A. 176

MacDonald, C. 159

madrasas, Tanzania 126, 127

maendeleo (development), Tanzania 73 , 81-82, 85, 229; emergence and

formation of 76-78; and self-help groups 143, 144

mageuzi (change/transformation), Tanzania 79, 85

Makerere University, Uganda 2, 160, 163-164, 179

Makoba, J.W. 194

Mamdani, M. 58

Matunga, Benta N. 9, 73-89, 139-155, 229

Mazingira group, Tanzania 149

Mbembe, A. 90, 91, 92, 97, 99, 100, 101

McGee, R. 219

MDGs (Millennium Development

Goals) 197, 204

Media Services Act 2016, Tanzania 82

Meinert, L. 96

men: self-help groups, Tanzania 148-149; see also patriarchal habits

Menike, K. 200

Mercer, C. 148

Merrifield, J. 139

migrants, in Uganda 61

Millennium Development Goals (MDGs) 197, 204

Ministry for Foreign Affairs of Finland 3

Misak, C. 37, 38

Mlimani Park group, Tanzania 146,147

multi-party system, Uganda 60-61
Museveni, Yoweri 59-60, 63, 64, 66, 67, 90, 93, 95, 185; visit to Kitgum town $94,96,97-100$

Mwenge wa Uhuru (Torch of Freedom) 144

Mwiine, A.A. 109

Namutumba District, Uganda see gendered citizenship, Uganda; participatory research, Uganda

narrative enquiry method, participatory research, Uganda 161

National Economic Survival Programme (1981-1982), Tanzania 79

National Resistance Movement, Uganda see NRM (National Resistance Movement), Uganda

NCCR (National Convention for Construction and Reform) - Mageuzi, Tanzania 80

Ndidde, Alice N. 9, 29, 105-120, 159-175, 176-193, 230-231

Nebanda, C. 94, 95

Neema A group, Tanzania 144, 147

NGO Act 2016, Uganda 186

NGOs (non-governmental organizations): communities of inquiry 176, 178; and critical education 194; growth of in Uganda 194; institutional wrestlings 179 ; relationship with government in Uganda 185-186, 196-197; and strengthening of citizenship 7; Tanzania 80-81, 141

Nguyahambi, Ajali M. 9, 73-89, 121-138, 210-226, 229, 230, 231

Nielsen, G.M. 20

Niringiye, Z. 101

non-democratic (hierarchical) societies 36,37

non-governmental organizations see NGOs (non-governmental organizations)

normativity 3-4, 32

NRM (National Resistance Movement), Uganda 59, 60, 61, 64, 93, 101, 185, 194; women's involvement in 116

Nyerere, Julius Kambarage 75, 77, 78, $79,80,82,84,125,135,142,197,199$, 201, 202

Obote, M. 59, 63, 65

oppression, impact on the oppressed 99 organizational growth: and institutional wrestlings 178-179, 189-190 
organizational learning 176, 190; ACFODE (Action for Development) 177, 180-190; advocacy approaches 185-187, 189; organizational restructuring $187-189$; and patriarchal habits 180-183; project implementation habits $183-185,189$; see also learning organizations

participation: "participatory development model" 78; right to 210-211; see also SAM (social accountability monitoring), and active citizenship

participatory approach 232-233; EDF 200-201, 204

participatory research, Uganda 9, 159-160, 172-173, 230-231; co-learning in 168-169, 169; critiques and shortfalls 160; designing fieldwork methodology 160-161; identification of participants 161-163; power relations and empowerment 170-171; researchers' positionality and self-revelation 163-165; tensions in 171, 172; Venn diagram exercise $165-171,167,169,172$

patriarchal habits $180-183$

peace (Islamic moral) 133

Peirce, C. S. 3, 31, 32, 36, 38

Pentecostal/Charismatic churches: Tanzania 121; Uganda 63

philosophical pragmatism 1, 3-4, 6; and citizenship 227-228; contributions to 234-235; see also pragmatism

physical inquiry 33-34

Political Parties Act 1992, Tanzania 79

Political Party Amendment Act 2018, Tanzania 82

"political," the, broad and narrow definitions of 20

power relations: and critical education 202, 203-204; North-South power asymmetries in development research $7-8,233$; in participatory research $159,167,170-171$

practice 23; practices of citizenship $15,16,17-21,23-24$, 228-230, 233; relationship to theory 4,15 pragmatism 3-4, 228-229, 232; and fallibilism 23; and social intelligence 44-45, 47-48; see also philosophical pragmatism promises, honouring of (Islamic moral) 129

Protestant (Anglican) Church, Uganda 60, 62-63, 90, 116, 196

Public and Its Problems, The (Dewey) 49

public, the, and Dewey 19-20, 21, 24, 49

Putnam, H. 36, 37, 38

Ravnkilde, S.M.C 216

Rawls, J. 31

Reason, P. 170

refugees, in Uganda 61

religious diversity, sub-Saharan Africa 23-24

religious virtues see Islamic morals and civic virtues in Tanzania

republicanism 18

Rodima-Taylor, D. 140, 147-148

Rogers, M.L. 124, 234

Rupia, J. 125

Rydenfelt, H. 9, 29-43, 227

SAM (social accountability monitoring), and active citizenship 210-213; Tanzania 9, 209-210, 212-223, 230, 231

SAPs (Structural Adjustment Programs) $78,79,210$

savings and credit groups see self-help groups, Tanzania; VSLAs (Village Savings and Loan Associations)

Schumpeter, J. 30

scientific inquiry $34-35,52$

SDGs (Sustainable Development Goals) 197, 204

self-help groups, Tanzania 139-142, 152-153, 229; and contributing citizenship 150-152; organization of interaction in $146-148,151$; participation in 148-150; shared problems addressed by $142-145$

service delivery see SAM (social accountability monitoring), and active citizenship, Tanzania

sexuality, Uganda 61-62

Sikika see SAM (social accountability monitoring), and active citizenship, Tanzania

social accountability monitoring see SAM (social accountability monitoring), and active citizenship social inquiry, Dewey's concept of 3, 234, 235; and democracy 32-34, 36, 39-40, 40-41, 228; and education 50-51 


\section{Index}

social intelligence, Dewey's concept of 9 , 44-48, 51-52, 227; implications of $48-51$

social nature of knowledge 19, 20, 22

social torture 93

Sohng, S.L. 159

spies, state, in Uganda 95-96

Stanford Encyclopedia of Philosophy 18

state violence, Uganda 90, 91-93, 102

Statistics Act 2018, Tanzania 82

Stitzlein, S.M. 140, 146

Structural Adjustment Programs (SAPs) $78,79,210$

subdued citizenship, northern Uganda 9, 57, 90-91, 101-102, 229; citizenship and state violence 91-93; citizenship learning at the spectacle 97-100; citizenship learning in the everyday $94-97$

submissive habitus, Acholi people, Uganda 99, 100, 101-102

Sukuma ethnic group, Tanganyika 74 sustainable development 201

Sustainable Development Goals (SDGs) 197, 204

Swahili, as language of Tanzania 74, 76,125

Sykes, Abdul 125

Sykes, Ali 125

TAA (Tanganyika African Association) 74,125

tafsir 127

Talisse, R. B. 23, 36-37

Tanganyika 74-75; see also Tanzania

TANU (Tanganyika African National Union) 75, 76-77

Tanzania 9, 73-74, 85, 229; active citizenship 9, 82, 83, 123, 134, 139, 150, 151, 209-210, 212-223, 231; civic education 77-78, 80, 82, 83; colonial period 74-75, 124-125; contemporary citizenship 84-85; contemporary multiparty politics $81-83$; CSOs (Civil Society Organizations) $80-81,82-83$, 213-223; education 74, 76, 83; ethnic diversity 74, 75, 142; and IGOs (International Governmental Organizations) 82-83; independence and nation-building period 74-76; key facts and statistics 86; literature 8; local definitions of citizenship 7; maendeleo, emergence and formation of 76-78; NGOs 80-81, 213-215; reforms and multiparty politics era 79-81; religious context 121-122, 124-126, 135; right of access to information 211, 214-215, 220, 221; SAM (social accountability monitoring), and active citizenship 9, 209-210, 212-223, 231; see also Islamic morals and civic virtues in Tanzania; self-help groups, Tanzania Tapscott, R. 96

theory: contextuality of theorization

48-49; relationship to practice 4, 15

Theory of Justice, A (Rawls) 31

Third World Conference on Women,

Nairobi, 1985, UN 179

tolerance (Islamic moral) 130

Torch of Freedom (Mwenge wa Uhuru) 144

Twaweza 82

Uganda 9, 67-68, 229; active citizenship $65,67,68,90,106,114,161$; belonging, and ethnicity $61-62$; characteristics of citizenship environments 61-64; civil society and local governance 66-67; colonial period 57-58, 65, 93; education system 57, 63, 64-66; environmental movement 66; ethnic diversity 196 ; expulsion of Asians, 1972 61; gendered citizenship 57; historical overview 57-61; key facts and statistics 68-69; literature 8; localized citizenship 57; multi-party system and hybrid governance 60-61; NGO/government relations 185-186, 196-197, 204;

NGOs 194; patronage 62, 66, 68, 108, 109; post-independence period 58-60; poverty in 97-98; religion 62-63; spaces for learning citizenship 64-67; state violence 90, 91-93, 102; women's movement 62, 66, 107, 177, 181, 185, 188, 203; see also ACFODE (Action for Development); EDF (Emesco Development Foundation), and critical education in Uganda; gendered citizenship, Uganda; participatory research, Uganda; subdued citizenship, northern Uganda

Uganda National Congress (UNC) 60

Uganda National Gender Policy (2007) 108

Ugandan National Council for Science and Technology 163 
Ujamaa policies, Tanzania 76-77, $79,84,125,142$; Ujamaa villages 75,76

Ulanga, Tanzania 146-147

UNC (Uganda National Congress) 60

University of Dodoma, Tanzania 2

University of Jyväskylä, Finland 2

University of Oulu, Finland 2

upatu (small savings groups),

Tanzania 141

Upendo group, Tanzania 142-143, 145, 146, 148, 149

utandawazi (globalization), Tanzania 79

Valderrama, C. 210

Verma, C. L. 95-96

VICOBA (Village Community Bank), Tanzania 142-143, 145

violence: gender-based violence 181,182 ; political violence, Uganda 63-64; state violence, Uganda 90, 91-93, 102;

unacceptability of in Islam 132

VSLAs (Village Savings and Loan

Associations) 141; Uganda

115-116; see also self-help groups,

Tanzania

WB (World Bank) 78, 79, 204-205, 210

Williams, M. 19

women: self-help groups, Tanzania 139,

148-149, 151-152; Uganda 107-109;

unacceptability of violence towards in

Islam 132; women's movement,

Uganda 62, 66, 107, 177, 181, 185, 188, 203; see also gendered citizenship, Uganda

work (Islamic moral) 132-133

World Bank (WB) 78, 79, 204-205, 210

"wrestlings" 177; see also institutional wrestlings 


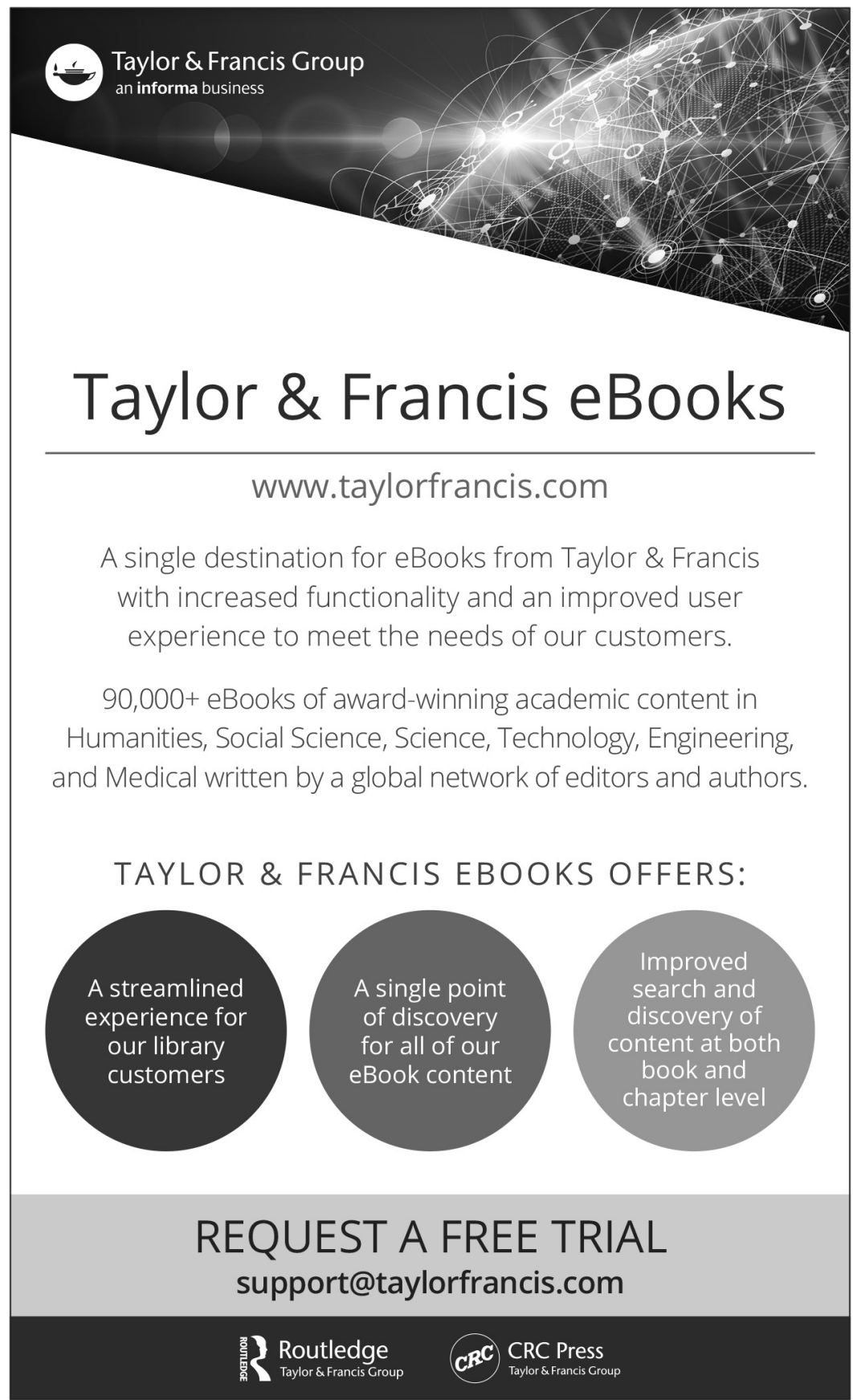

